\title{
Urban Wood Waste Resource
} Assessment

G. Wiltsee

Appel Consultants,Inc.

Valencia, $C A$

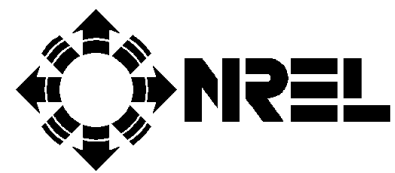

National Renewable Energy Laboratory 1617 Cole Boulevard

Golden, Colorado 80401-3393

A national laboratory of the U.S. Department of Energy Managed by Midwest Research Institute for the U.S. Department of Energy under contract No. DE-AC36-83CH10093 


\section{Urban Wood Waste Resource}

\section{Assessment}

G. Wiltsee

Appel Consultants, Inc.

Valencia, $C A$

NREL technical monitor: K.S. Tyson

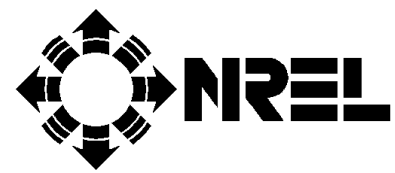

National Renewable Energy Laboratory 1617 Cole Boulevard

Golden, Colorado 80401-3393

A national laboratory of the U.S. Department of Energy Managed by Midwest Research Institute for the U.S. Department of Energy under contract No. DE-AC36-83CH10093

Prepared under Subcontract No. ACG-7-17090-01

November 1998 
This publication was reproduced from the best available copy Submitted by the subcontractor and received no editorial review at NREL

\section{NOTICE}

This report was prepared as an account of work sponsored by an agency of the United States government. Neither the United States government nor any agency thereof, nor any of their employees, makes any warranty, express or implied, or assumes any legal liability or responsibility for the accuracy, completeness, or usefulness of any information, apparatus, product, or process disclosed, or represents that its use would not infringe privately owned rights. Reference herein to any specific commercial product, process, or service by trade name, trademark, manufacturer, or otherwise does not necessarily constitute or imply its endorsement, recommendation, or favoring by the United States government or any agency thereof. The views and opinions of authors expressed herein do not necessarily state or reflect those of the United States government or any agency thereof.

Available to DOE and DOE contractors from:

Office of Scientific and Technical Information (OSTI)

P.O. Box 62

Oak Ridge, TN 37831

Prices available by calling (423) 576-8401

Available to the public from:

National Technical Information Service (NTIS)

U.S. Department of Commerce

5285 Port Royal Road

Springfield, VA 22161

(703) 605-6000 or (800) 553-6847

or

DOE Information Bridge

http://www.doe.gov/bridge/home.html

Printed on paper containing at least $50 \%$ wastepaper, including $20 \%$ postconsumer waste 


\section{CONTENTS}

\section{Section}

Page

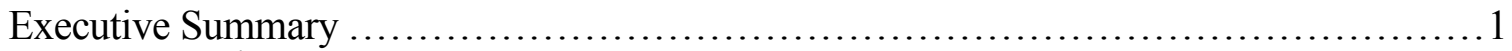

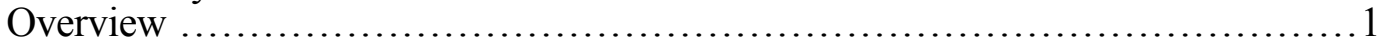

Uses and Disposal Methods for Urban Wood Wastes ..............................2

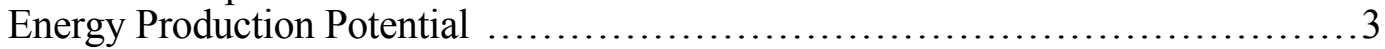

Municipal Solid Waste (MSW) Collection and Disposal ........................... 4

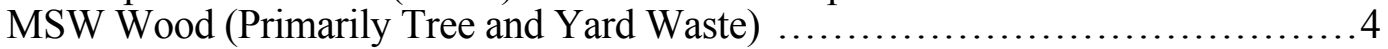

Industrial Wood Wastes ................................................... 4

Construction/Demolition Wood Wastes ......................................6

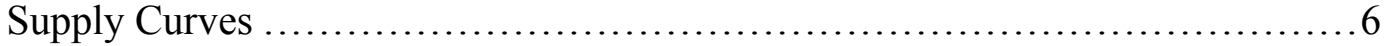

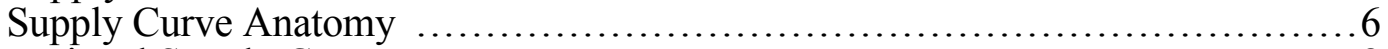

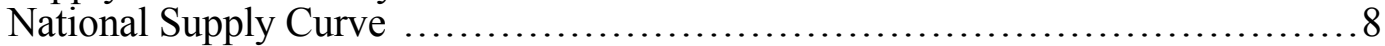

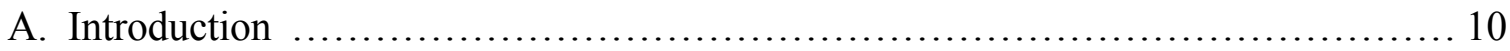

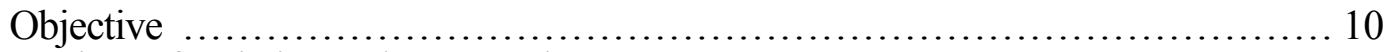

Review of Existing Urban Wood Waste Resource Assessments .................. 10

Categories and Key Variables ................................................ 13

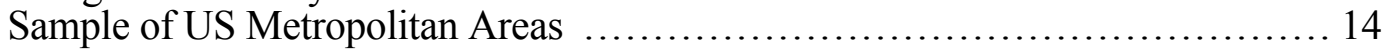

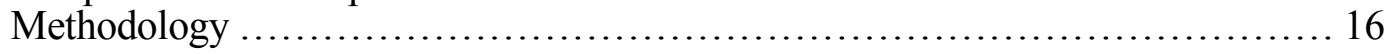

B. Overview of Urban Wood Resource Data ....................................... 20

Urban Wood Resources .................................................. 20

Statistical Analysis of the Data ......................................... 20

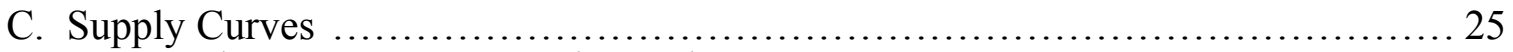

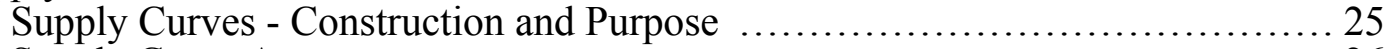

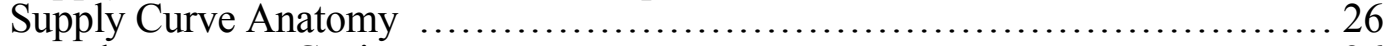

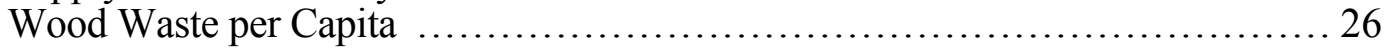

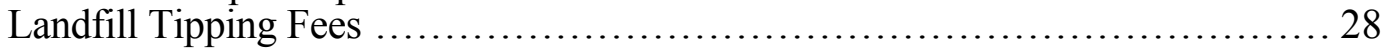

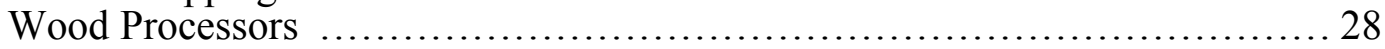

Private Dumping or Recycling ......................................... 29

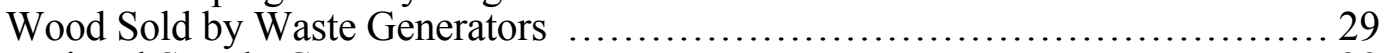

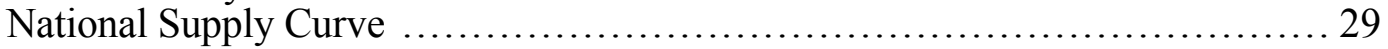

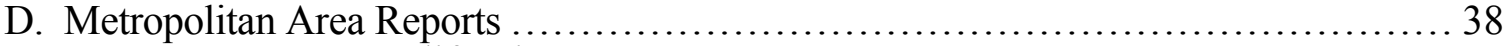

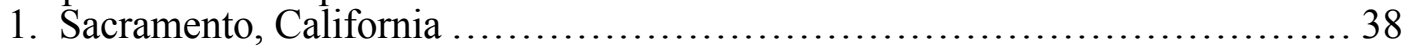

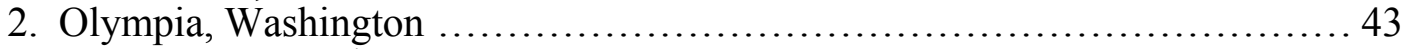

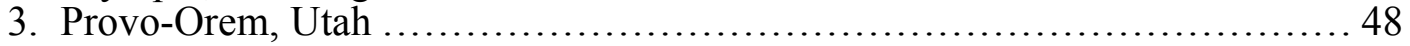

4. Denver-Boulder, Colorado …......................................... 53

5. Lincoln, Nebraska ......................................................... 59

6. Bismarck, North Dakota ............................................. 65

7. Bloomington-Normal, Illinois ............................................... 70

8. Battle Creek, Michigan ................................................ 75

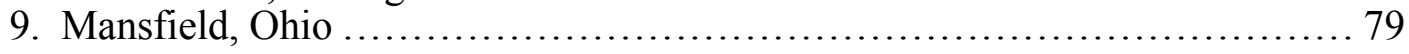


D. Metropolitan Area Reports (continued)

10. Elmira, New York 83

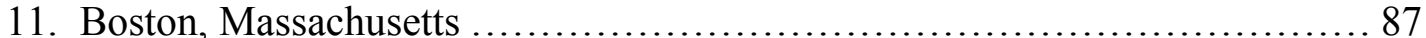

12. Harrisburg-Lebanon-Carlisle, Pennsylvania ….......................... 95

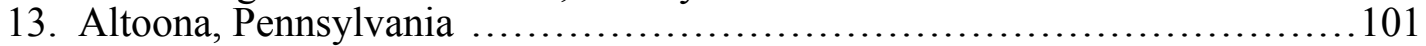

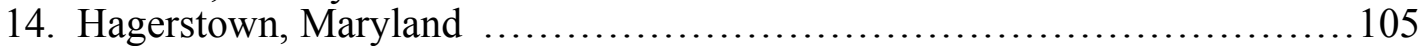

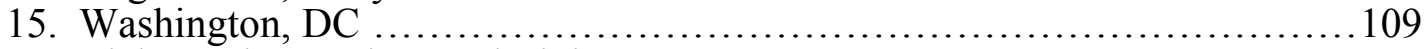

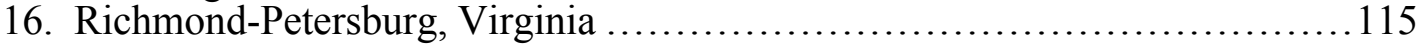

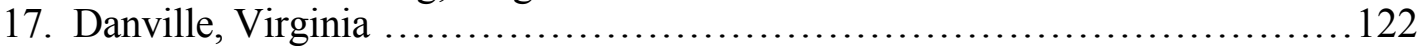

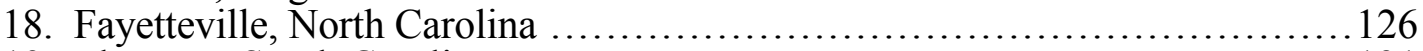

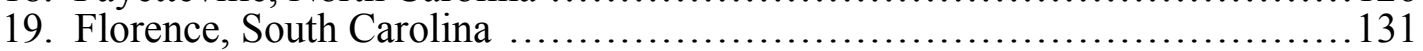

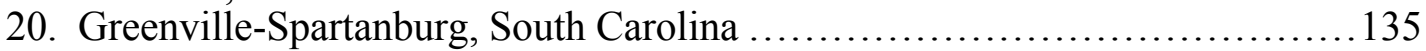

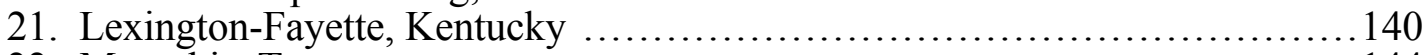

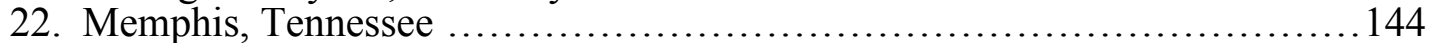

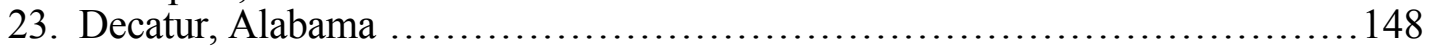

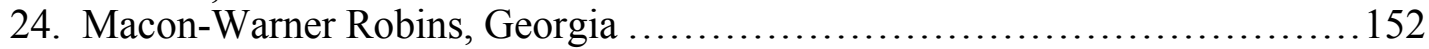

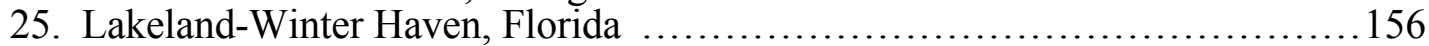

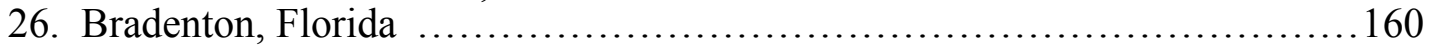

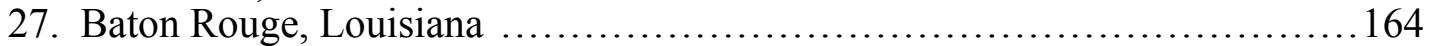

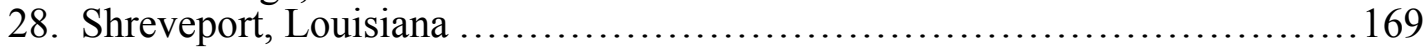

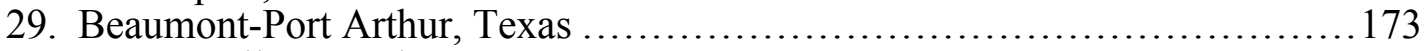

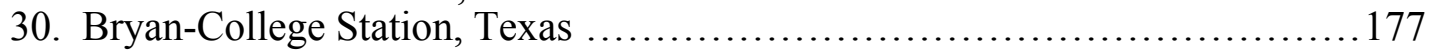

Appendices

A. Metropolitan Areas ...................................................

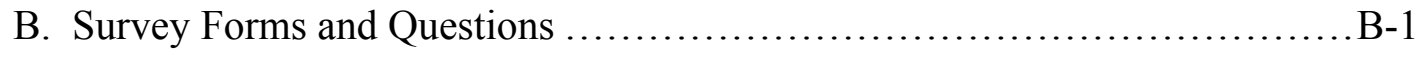

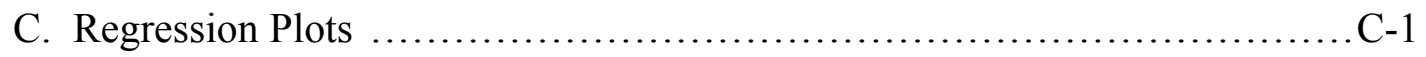




\section{TABLES}

Table

Page

1. Summary of Urban Wood Resources in 30 Metropolitan Areas, Tons/Year/Person ....1

2. Primary Uses and Disposal Methods for Urban Wood Wastes .......................2

3. Amounts and End Uses of Urban Wood Resources in 30 Metropolitan Areas .......... 3

4. MSW Wood: Generators and End Uses, Tons/Year/Person ........................5

5. Industrial Wood: Generators and End Uses, Tons/Year/Person ..................... 5

6. Data and Assumptions Used in Supply Curve for Richmond-Petersburg ............... 7

7. Data Compilation: Previous Urban Wood Waste Resource Assessments ............ 13

8. Sample of 30 Metropolitan Areas ............................................ 15

9. Size Distributions: Sample of 30 and 281 US Metropolitan Areas ................... 16

10. Yellow Pages Categories Used to Develop Contact Lists ........................ 17

11. Urban Wood Resources in 30 Metropolitan Areas, Tons/Year .................... 21

12. Urban Wood Resources in 30 Metropolitan Areas, Tons/Year/Person .............. 22

13. Regression Coefficients: 30 vs. 28 Cities .................................. 23

14. Housing Permits and C/D Wood Resources in 30 Metropolitan Areas .............. 24

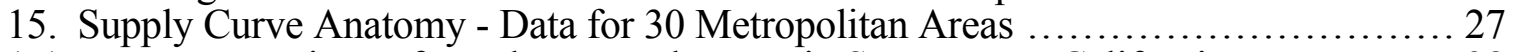

1-1. Resource Estimate for Urban Wood Waste in Sacramento, California ............... 38

1-2. Wood Wastes Processed by Waste Management, Inc. .............................. 39

1-3. Resource Estimate for MSW Wood in Sacramento, California ...................... 40

1-4. Resource Estimate for Industrial Wood Wastes in Sacramento, California .......... 41

1-5. Data and Assumptions Used in Supply Curve for Sacramento ................... 42

2-1. Resource Estimate for Urban Wood Waste in Olympia, Washington .............. 43

2-2. Resource Estimate for MSW Wood in Olympia, Washington . .................. 45

2-3. Resource Estimate for Industrial Wood Wastes in Olympia, Washington ........... 46

2-4. Data and Assumptions Used in Supply Curve for Olympia ...................... 47

3-1. Resource Estimate for Urban Wood Waste in Provo-Orem, Utah ................. 48

3-2. Resource Estimate for MSW Wood in Provo-Orem, Utah ....................... 50

3-3. Resource Estimate for Industrial Wood Wastes in Provo-Orem, Utah ............. 51

3-4. Data and Assumptions Used in Supply Curve for Provo-Orem ..................... 52

4-1. Resource Estimate for Urban Wood Waste in Denver-Boulder, Colorado ........... 53

4-2. MSW Disposal Rates at Denver-Boulder Area Landfills, 1996 ..................... 54

4-3. Resource Estimate for MSW Wood in Denver-Boulder, Colorado ................... 56

4-4. Resource Estimate for Industrial Wood Wastes in Denver-Boulder, Colorado ...... 57

4-5. Data and Assumptions Used in Supply Curve for Denver-Boulder ................ 58

5-1. Resource Estimate for Urban Wood Waste in Lincoln, Nebraska .................. 60

5-2. Resource Estimate for MSW Wood in Lincoln, Nebraska ....................... 62

5-3. Resource Estimate for Industrial Wood Wastes in Lincoln, Nebraska .............. 63

5-4. Data and Assumptions Used in Supply Curve for Lincoln ...................... 64

6-1. Resource Estimate for Urban Wood Waste in Bismarck, North Dakota ............. 65

6-2. Resource Estimate for MSW Wood in Bismarck, North Dakota ................... 67

6-3. Resource Estimate for Industrial Wood Wastes in Bismarck, North Dakota ........ 68

6-4. Data and Assumptions Used in Supply Curve for Bismarck ..................... 69

7-1. Resource Estimate for Urban Wood Waste in Bloomington-Normal, Illinois ...... 70

7-2. Resource Estimate for MSW Wood in Bloomington-Normal, Illinois ............. 72 
7-3. Resource Estimate for Industrial Wood Wastes in Bloomington-Normal, Illinois .. 73

7-4. Data and Assumptions Used in Supply Curve for Bloomington-Normal ............ 74

8-1. Resource Estimate for Urban Wood Waste in Battle Creek, Michigan .............. 75

8-2. Resource Estimate for MSW Wood in Battle Creek, Michigan ................... 76

8-3. Resource Estimate for Industrial Wood Wastes in Battle Creek, Michigan ........... 77

8-4. Data and Assumptions Used in Supply Curve for Battle Creek ................... 78

9-1. Resource Estimate for Urban Wood Waste in Mansfield, Ohio .................... 79

9-2. Resource Estimate for MSW Wood in Mansfield, Ohio ....................... 80

9-3. Resource Estimate for Industrial Wood Wastes in Mansfield, Ohio ............... 81

9-4. Data and Assumptions Used in Supply Curve for Mansfield .................... 82

10-1. Resource Estimate for Urban Wood Waste in Elmira, New York ............... 83

10-2. Resource Estimate for MSW Wood in Elmira, New York ...................... 84

10-3. Resource Estimate for Industrial Wood Wastes in Elmira, New York ............ 85

10-4. Data and Assumptions Used in Supply Curve for Elmira ........................ 86

11-1. Resource Estimate for Urban Wood Waste in Boston, Massachusetts ............ 87

11-2. Resource Estimate for MSW Wood in Boston, Massachusetts ................... 90

11-3. Resource Estimate for Industrial Wood Wastes in Boston, Massachusetts ........ 92

11-4. Data and Assumptions Used in Supply Curve for Boston ...................... 93

11-5. Boston -- Cities Included in Survey Area ................................... 94

12-1. Resource Estimate for Urban Wood Waste in Harrisburg, Pennsylvania .......... 95

12-2. Resource Estimate for MSW Wood in Harrisburg, Pennsylvania ................ 97

12-3. Resource Estimate for Industrial Wood Wastes in Harrisburg, Pennsylvania ...... 99

12-4. Data and Assumptions Used in Supply Curve for Harrisburg .................... 100

13-1. Resource Estimate for Urban Wood Waste in Altoona, Pennsylvania ...............101

13-2. Resource Estimate for MSW Wood in Altoona, Pennsylvania .................... 102

13-3. Resource Estimate for Industrial Wood Wastes in Altoona, Pennsylvania .........103

13-4. Data and Assumptions Used in Supply Curve for Altoona ....................... 104

14-1. Resource Estimate for Urban Wood Waste in Hagerstown, Maryland ............. 105

14-2. Resource Estimate for MSW Wood in Hagerstown, Maryland ................... 106

14-3. Resource Estimate for Industrial Wood Wastes in Hagerstown, Maryland ........ 107

14-4. Data and Assumptions Used in Supply Curve for Hagerstown ................... 108

15-1. Resource Estimate for Urban Wood Waste in Washington, DC .................. 109

15-2. Resource Estimate for MSW Wood in Washington, DC ...................... 112

15-3. Resource Estimate for Industrial Wood Wastes in Washington, DC . ..............113

15-4. Data and Assumptions Used in Supply Curve for Washington, DC ...............114

16-1. Resource Estimate for Urban Wood Waste in Richmond-Petersburg, Virginia ...115

16-2. Resource Estimate for MSW Wood in Richmond-Petersburg, Virginia ............118

16-3. Resource Estimate for Industrial Wood Wastes in Richmond-Petersburg, VA .... 119

16-4. Data and Assumptions Used in Supply Curve for Richmond-Petersburg .........121

17-1. Resource Estimate for Urban Wood Waste in Danville, Virginia ..................122

17-2. Resource Estimate for MSW Wood in Danville, Virginia ......................... 123

17-3. Resource Estimate for Industrial Wood Wastes in Danville, Virginia .............124

17-4. Data and Assumptions Used in Supply Curve for Danville ..................... 125

18-1. Resource Estimate for Urban Wood Waste in Fayetteville, North Carolina ....... 126

18-2. Resource Estimate for MSW Wood in Fayetteville, North Carolina ...............128

18-3. Resource Estimate for Industrial Wood Wastes in Fayetteville, North Carolina .. 129

18-4. Data and Assumptions Used in Supply Curve for Fayetteville . ................130

19-1. Resource Estimate for Urban Wood Waste in Florence, South Carolina ...........131

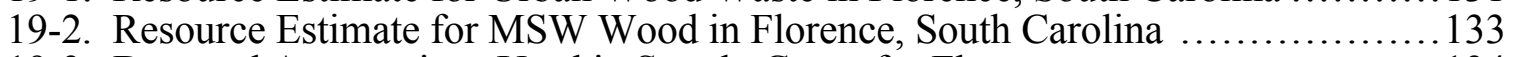

19-3. Data and Assumptions Used in Supply Curve for Florence ..................... 134

20-1. Resource Estimate for Urban Wood Waste in Greenville-Spartanburg, SC ...... 135

20-2. Resource Estimate for MSW Wood in Greenville-Spartanburg, SC .............. 137 
20-3. Resource Estimate for Industrial Wood Wastes in Greenville-Spartanburg, SC .. 138

20-4. Data and Assumptions Used in Supply Curve for Greenville-Spartanburg ........ 139

21-1. Resource Estimate for Urban Wood Waste in Lexington-Fayette, KY ............. 140

21-2. Resource Estimate for MSW Wood in Lexington-Fayette, KY ................. 141

21-3. Resource Estimate for Industrial Wood Wastes in Lexington-Fayette, KY ........142

21-4. Data and Assumptions Used in Supply Curve for Lexington-Fayette ............. 143

22-1. Resource Estimate for Urban Wood Waste in Memphis, Tennessee ..............144

22-2. Resource Estimate for MSW Wood in Memphis, Tennessee ................... 145

22-3. Resource Estimate for Industrial Wood Wastes in Memphis, Tennessee .......... 146

22-4. Data and Assumptions Used in Supply Curve for Memphis ....................... 147

23-1. Resource Estimate for Urban Wood Waste in Decatur, Alabama ................... 148

23-2. Resource Estimate for MSW Wood in Decatur, Alabama ........................149

23-3. Resource Estimate for Industrial Wood Wastes in Decatur, Alabama .............150

23-4. Data and Assumptions Used in Supply Curve for Decatur ........................151

24-1. Resource Estimate for Urban Wood Waste in Macon-Warner Robins, GA ....... 152

24-2. Resource Estimate for MSW Wood in Macon-Warner Robins, GA .............. 153

24-3. Resource Estimate for Industrial Wood Wastes in Macon-Warner Robins, GA .. 154

24-4. Data and Assumptions Used in Supply Curve for Macon-Warner Robins ......... 155

25-1. Resource Estimate for Urban Wood Waste in Lakeland-Winter Haven, FL ....... 156

25-2. Resource Estimate for MSW Wood in Lakeland-Winter Haven, FL ..............157

25-3. Resource Estimate for Industrial Wood Wastes in Lakeland-Winter Haven, FL .. 158

25-4. Data and Assumptions Used in Supply Curve for Lakeland-Winter Haven ....... 159

26-1. Resource Estimate for Urban Wood Waste in Bradenton, Florida ................. 160

26-2. Resource Estimate for MSW Wood in Bradenton, Florida ........................161

26-3. Resource Estimate for Industrial Wood Wastes in Bradenton, Florida ............. 162

26-4. Data and Assumptions Used in Supply Curve for Bradenton ...................... 163

27-1. Resource Estimate for Urban Wood Waste in Baton Rouge, Louisiana ............. 164

27-2. Resource Estimate for MSW Wood in Baton Rouge, Louisiana .................. 166

27-3. Resource Estimate for Industrial Wood Wastes in Baton Rouge, Louisiana ....... 167

27-4. Data and Assumptions Used in Supply Curve for Baton Rouge ................ 168

28-1. Resource Estimate for Urban Wood Waste in Shreveport, Louisiana ..............169

28-2. Resource Estimate for MSW Wood in Shreveport, Louisiana ...................170

28-3. Resource Estimate for Industrial Wood Wastes in Shreveport, Louisiana .........171

28-4. Data and Assumptions Used in Supply Curve for Shreveport ...................172

29-1. Resource Estimate for Urban Wood Waste in Beaumont-Port Arthur, Texas .....173

29-2. Resource Estimate for MSW Wood in Beaumont-Port Arthur, Texas ................174

29-3. Resource Estimate for Industrial Wood Wastes in Beaumont-Port Arthur, TX ... 175

29-4. Data and Assumptions Used in Supply Curve for Beaumont-Port Arthur ........ 176

30-1. Resource Estimate for Urban Wood Waste in Bryan-College Station, Texas .....177

30-2. Resource Estimate for MSW Wood in Bryan-College Station, Texas ............. 178

30-3. Data and Assumptions Used in Supply Curve for Bryan-College Station ......... 179 


\section{FIGURES}

\section{Figure}

Page

1. Supply Curve for Urban Wood Wastes in Richmond-Petersburg, Virginia ............. 7

2. Supply Curve Projected for All Metropolitan Areas in the United States ................ 9

3. Cities with the Largest Populations ................................................ 30

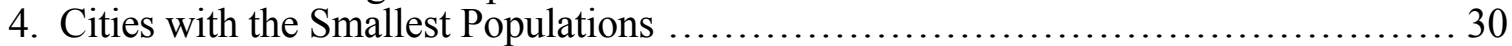

5. Cities with the Most Wood Waste per Capita ..................................... 31

6. Cities with the Least Wood Waste per Capita .......................................... 31

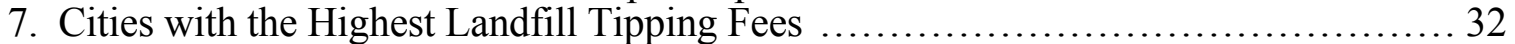

8. Cities with the Lowest Landfill Tipping Fees …................................. 32

9. Cities with the Highest Percentage of Wood Landfilled ............................ 33

10. Cities with the Lowest Percentage of Wood Landfilled ............................ 33

11. Cities with the Highest Percentage of Wood Processed .......................... 34

12. Cities with the Lowest Percentage of Wood Processed ............................ 34

13. Cities with the Highest Percentage of Wood Privately Dumped or Recycled ......... 35

14. Cities with the Lowest Percentage of Wood Privately Dumped or Recycled ......... 35

15. Cities with the Highest Percentage of Wood Sold by Waste Generators ............. 36

16. Cities with the Lowest Percentage of Wood Sold by Waste Generators ............... 36

17. Supply Curve Projected for All Metropolitan Areas in the United States ............. 37

1-1. Supply Curve for Urban Wood Wastes in Sacramento, California ................. 42

2-1. Supply Curve for Urban Wood Wastes in Olympia, Washington ................... 47

3-1. Supply Curve for Urban Wood Wastes in Provo-Orem, Utah ................... 52

4-1. Supply Curve for Urban Wood Wastes in Denver-Boulder, Colorado .............. 58

5-1. Supply Curve for Urban Wood Wastes in Lincoln, Nebraska ....................... 64

6-1. Supply Curve for Urban Wood Wastes in Bismarck, North Dakota ................. 69

7-1. Supply Curve for Urban Wood Wastes in Bloomington-Normal, Illinois ........... 74

8-1. Supply Curve for Urban Wood Wastes in Battle Creek, Michigan ................. 78

9-1. Supply Curve for Urban Wood Wastes in Mansfield, Ohio ....................... 82

10-1. Supply Curve for Urban Wood Wastes in Elmira, New York …............... 86

11-1. Supply Curve for Urban Wood Wastes in Boston, Massachusetts ................... 93

12-1. Supply Curve for Urban Wood Wastes in Harrisburg, Pennsylvania ............... 100

13-1. Supply Curve for Urban Wood Wastes in Altoona, Pennsylvania .................104

14-1. Supply Curve for Urban Wood Wastes in Hagerstown, Maryland ................. 108

15-1. Supply Curve for Urban Wood Wastes in Washington, DC .....................114

16-1. Supply Curve for Urban Wood Wastes in Richmond-Petersburg, Virginia ........121

17-1. Supply Curve for Urban Wood Wastes in Danville, Virginia .....................125

18-1. Supply Curve for Urban Wood Wastes in Fayetteville, North Carolina ............130

19-1. Supply Curve for Urban Wood Wastes in Florence, South Carolina ...............134

20-1. Supply Curve for Urban Wood Wastes in Greenville-Spartanburg, SC ...........139

21-1. Supply Curve for Urban Wood Wastes in Lexington-Fayette, Kentucky ..........143

22-1. Supply Curve for Urban Wood Wastes in Memphis, Tennessee ...................147

23-1. Supply Curve for Urban Wood Wastes in Decatur, Alabama ....................151

24-1. Supply Curve for Urban Wood Wastes in Macon-Warner Robins, Georgia .......155

25-1. Supply Curve for Urban Wood Wastes in Lakeland-Winter Haven, Florida ........159

26-1. Supply Curve for Urban Wood Wastes in Bradenton, Florida ....................163 


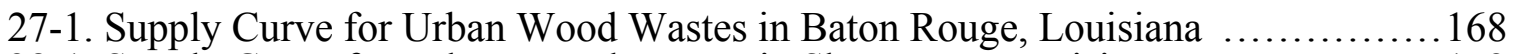

28-1. Supply Curve for Urban Wood Wastes in Shreveport, Louisiana ..................172

29-1. Supply Curve for Urban Wood Wastes in Beaumont-Port Arthur, Texas ..........176

30-1. Supply Curve for Urban Wood Wastes in Bryan-College Station, Texas .......... 179 


\section{EXECUTIVE SUMMARY}

\section{Overview}

This study, which was funded by the US Department of Energy's National Renewable Energy Laboratory (NREL), collected and analyzed data on urban wood waste resources in 30 randomly selected metropolitan areas in the United States. The metropolitan areas ranged in size from Bismarck, North Dakota $(83,831)$ to Washington, DC $(3,923,574)$. Three major categories of urban wood wastes were considered in this study:

1) wood wastes disposed of with, or recovered from, the municipal solid waste (MSW) stream ("MSW wood");

2) industrial wood wastes such as wood scraps and sawdust from pallet recycling, woodworking shops, and lumber yards; and

3) wood in construction/demolition (C/D) and land clearing debris.

Metropolitan areas in the US differ considerably in the amounts of the three basic types of urban wood wastes generated and then disposed of or recovered for commercial use. The significant variations in the methods and costs of urban wood waste disposal and reuse are related to factors such as the levels of landfill tipping fees, access to and regulations concerning rural dumping and burning, public policies that promote waste diversion or recycling, and the proximity of large wood waste users (power plants, cogeneration plants, pulp and paper mills, and medium-density fiberboard plants, for example).

The study included statistical analysis of the data to develop predictive tools for estimation of urban wood waste resources as a function of demographic and economic variables. Logically and empirically, urban wood resources are related to the population of a metropolitan area. Table 1 shows the ranges and the weighted average of per capita urban wood resources found in this study, as well as the regression coefficients. The units are in tons of wood (including moisture) generated per year per person. ${ }^{1}$

Table 1

Summary of Urban Wood Resources in 30 Metropolitan Areas Tons/Year/Person

\begin{tabular}{|c|c|c|c|c|}
\hline & Low & High & $\begin{array}{l}\text { Weighted } \\
\text { Average }\end{array}$ & $\begin{array}{l}\text { Regression } \\
\text { Coefficient }\end{array}$ \\
\hline MSW wood & 0.134 & 0.538 & 0.209 & 0.203 \\
\hline Industrial wood & 0.001 & 0.488 & 0.048 & 0.039 \\
\hline C/D wood & 0.015 & 0.250 & 0.076 & 0.091 \\
\hline Total urban wood & 0.156 & 0.829 & 0.333 & 0.333 \\
\hline
\end{tabular}

\footnotetext{
1 "Weighted average" means the total tons/year generated, divided by the total population of the 30 metropolitan areas sampled. The regression coefficients shown are for a reduced sample of 28 metropolitan areas, with two "outliers" (Washington, DC and Richmond, VA) removed.
} 


\section{Uses and Disposal Methods for Urban Wood Wastes}

Table 2 shows the primary uses and disposal methods for urban wood wastes in the 30 metropolitan areas as a whole. ${ }^{2}$ There is considerable variation from one city to another in the relative amounts of wood going to these different end uses (or non-uses), but in general the two most common are grinding the wood to mulch for land application, and landfilling or incinerating the wood along with MSW or C/D debris. For the 30 cities as a group, these two end uses account for almost $73 \%$ of the total urban wood resource. Biomass fuel comes in a distant third, at 12\%. The other significant uses are firewood (about $7 \%$ ) and industrial feedstocks such as furnish for particleboard plants, saw logs, and pulp chips (about 5\%). Rural dumping or burning and animal bedding each account for about $1 \%$ of the total urban wood resource (although the former is a much higher percentage of the total in some areas). Specialty products include items such as colored chips, fuel pellets and pressed firelogs, which make up an insignificant portion of the total.

Table 2

Primary Uses and Disposal Methods for Urban Wood Wastes

\begin{tabular}{|c|c|c|c|c|c|c|}
\hline \multirow[b]{2}{*}{ Use or disposal method: } & \multicolumn{4}{|c|}{ Tons/Year/Person } & \multirow[b]{2}{*}{$\begin{array}{l}\text { Percent } \\
\text { of Total } \\
\end{array}$} & \multirow[b]{2}{*}{$\begin{array}{l}\text { Price, } \\
\text { \$/ton }\end{array}$} \\
\hline & $\begin{array}{l}\text { MSW } \\
\text { Wood } \\
\end{array}$ & $\begin{array}{c}\text { Industrial } \\
\text { Wood } \\
\end{array}$ & $\begin{array}{c}\text { C/D } \\
\text { Wood } \\
\end{array}$ & Total & & \\
\hline Mulch & 0.109 & 0.011 & 0.011 & 0.131 & 39.3 & -45 to 3 \\
\hline Landfill or incineration & 0.054 & 0.005 & 0.052 & 0.111 & 33.4 & -85 to -20 \\
\hline Biomass fuel & 0.019 & 0.013 & 0.008 & 0.040 & 12.0 & -45 to 0 \\
\hline Firewood & 0.022 & 0.002 & 0.000 & 0.025 & 7.4 & -5 to 0 \\
\hline Furnish, logs, pulp chips & 0.002 & 0.012 & 0.001 & 0.016 & 5.1 & -25 to 12 \\
\hline Rural dumping or burning & 0.003 & 0.000 & 0.002 & 0.004 & 1.4 & -5 to 0 \\
\hline Animal bedding & 0.000 & 0.004 & 0.000 & 0.004 & 1.2 & 0 to 3 \\
\hline Specialty products & 0.000 & 0.001 & 0.002 & $\underline{0.002}$ & 0.2 & -9 to 0 \\
\hline Total urban & 0.209 & 0.048 & 0.076 & 0.333 & 100.0 & \\
\hline Percent of total & 62.7 & 14.5 & 22.9 & 100.0 & & \\
\hline
\end{tabular}

To illustrate the variability in urban wood waste resources and end use percentages from city to city, Table 3 lists the 30 metropolitan areas studied, their populations and total per capita wood waste resources, and the percentages of their total wood waste resources that fall into the end use categories mulch, landfill or incineration, biomass fuel, and other. The "other" category in Table 3 combines the last five end uses in Table 2. The fraction of total urban wood wastes converted to mulch ranges from $14 \%$ in Shreveport to $84 \%$ in Bloomington-Normal. ${ }^{3}$ Conversely, the fraction of urban wood wastes landfilled ranges from $11 \%$ in Bloomington-Normal to $78 \%$ in Shreveport. Fifteen of the 30 metropolitan areas produce no biomass fuel from their urban wood wastes; on the other hand, five cities convert over $20 \%$ of their urban wood wastes to biomass fuel: Lakeland-Winter Haven $(46 \%)$, Boston (46\%), Danville, VA (23\%), Fayetteville $(21 \%)$, and Sacramento $(21 \%)$. The "other" category (firewood, furnish, saw logs, pulp chips, rural dumping or burning, animal bedding, and specialty products) ranges from $1 \%$ in Bradenton to $44 \%$ in Altoona.

\footnotetext{
${ }^{2}$ The prices in Table 2 are the net payments or costs incurred by the primary generators of the wood wastes, and are discussed later in the context of supply curves.

${ }^{3}$ City names followed by dashes in Table 3 indicate that additional cities are included in the official name of the metropolitan area (e.g., Provo-Orem).
} 
Table 3

Amounts and End Uses of Urban Wood Resources in 30 Metropolitan Areas

\begin{tabular}{|c|c|c|c|c|c|c|c|c|c|}
\hline \multirow[b]{2}{*}{ No. } & \multirow[b]{2}{*}{ Metro Area } & \multirow[b]{2}{*}{ State } & \multirow[b]{2}{*}{ Population } & \multirow[b]{2}{*}{$\underline{\mathbf{T}} / \mathbf{Y} / \mathbf{P}$} & \multicolumn{5}{|c|}{ \% of Total Urban Wood Wastes } \\
\hline & & & & & Mulch & Lndfl & Bfuel & Other & Total \\
\hline 1 & Sacramento & $\mathrm{CA}$ & $1,481,102$ & 0.300 & 36.9 & 20.0 & 20.7 & 22.5 & 100.0 \\
\hline 2 & Olympia & WA & 161,238 & 0.505 & 63.9 & 12.3 & 6.1 & 17.7 & 100.0 \\
\hline 3 & Provo- & UT & 263,590 & 0.330 & 66.3 & 25.3 & 0.0 & 8.4 & 100.0 \\
\hline 4 & Denver- & $\mathrm{CO}$ & $1,848,319$ & 0.313 & 29.5 & 63.3 & 0.0 & 7.2 & 100.0 \\
\hline 5 & Lincoln & $\mathrm{NE}$ & 213,641 & 0.438 & 38.5 & 46.0 & 0.0 & 15.5 & 100.0 \\
\hline 6 & Bismarck & ND & 83,831 & 0.235 & 26.0 & 32.2 & 0.0 & 41.7 & 100.0 \\
\hline 7 & Bloomington- & $\mathrm{IL}$ & 129,180 & 0.379 & 83.9 & 11.0 & 0.0 & 5.1 & 100.0 \\
\hline 8 & Battle Creek & MI & 135,982 & 0.308 & 66.4 & 16.7 & 0.0 & 16.8 & 100.0 \\
\hline 9 & Mansfield & $\mathrm{OH}$ & 126,137 & 0.291 & 31.3 & 27.2 & 0.0 & 41.5 & 100.0 \\
\hline 10 & Elmira & NY & 95,195 & 0.269 & 33.2 & 42.5 & 7.8 & 16.5 & 100.0 \\
\hline 11 & Boston & MA & $1,950,855$ & 0.330 & 20.7 & 27.7 & 45.5 & 6.1 & 100.0 \\
\hline 12 & Harrisburg- & PA & 587,986 & 0.245 & 43.7 & 29.8 & 4.7 & 21.7 & 100.0 \\
\hline 13 & Altoona & PA & 130,542 & 0.430 & 42.2 & 13.9 & 0.0 & 43.9 & 100.0 \\
\hline 14 & Hagerstown & $\mathrm{MD}$ & 121,393 & 0.358 & 57.6 & 21.2 & 0.0 & 21.2 & 100.0 \\
\hline 15 & Washington & $\mathrm{DC}$ & $3,923,574$ & 0.156 & 58.6 & 24.7 & 0.0 & 16.7 & 100.0 \\
\hline 16 & Richmond- & VA & 865,640 & 0.829 & 42.2 & 14.8 & 15.6 & 27.4 & 100.0 \\
\hline 17 & Danville & VA & 108,711 & 0.727 & 17.7 & 16.5 & 22.8 & 43.0 & 100.0 \\
\hline 18 & Favetteville & $\mathrm{NC}$ & 274,566 & 0.322 & 23.4 & 45.0 & 21.4 & 10.2 & 100.0 \\
\hline 19 & Florence & $\mathrm{SC}$ & 114,344 & 0.273 & 35.9 & 54.5 & 0.0 & 9.6 & 100.0 \\
\hline 20 & Greenville- & $\mathrm{SC}$ & 640,861 & 0.443 & 46.5 & 37.3 & 5.6 & 10.6 & 100.0 \\
\hline 21 & Lexington- & $\mathrm{KY}$ & 348,428 & 0.278 & 50.5 & 37.4 & 0.5 & 11.5 & 100.0 \\
\hline 22 & Memphis & $\mathrm{TN}$ & 981,747 & 0.378 & 35.8 & 59.2 & 0.0 & 5.0 & 100.0 \\
\hline 23 & Decatur & $\mathrm{AL}$ & 131,556 & 0.426 & 39.3 & 24.6 & 12.5 & 23.6 & 100.0 \\
\hline 24 & Macon- & GA & 281,103 & 0.347 & 39.0 & 40.8 & 5.1 & 15.1 & 100.0 \\
\hline 25 & Lakeland- & FL & 405,382 & 0.523 & 29.5 & 21.2 & 46.0 & 3.3 & 100.0 \\
\hline 26 & Bradenton & $\mathrm{FL}$ & 211,707 & 0.654 & 76.2 & 22.4 & 0.0 & 1.4 & 100.0 \\
\hline 27 & Baton Rouge & LA & 528,264 & 0.490 & 16.6 & 53.4 & 0.8 & 29.3 & 100.0 \\
\hline 28 & Shreveport & LA & 334,341 & 0.325 & 13.8 & 77.7 & 0.0 & 8.5 & 100.0 \\
\hline 29 & Beaumont- & $\mathrm{TX}$ & 361,226 & 0.340 & 70.1 & 22.2 & 2.4 & 5.2 & 100.0 \\
\hline 30 & Bryan- & TX & 121,862 & 0.281 & 26.2 & 37.9 & 0.0 & 35.9 & 100.0 \\
\hline To & al - 30 metro a & eas & $16,962,303$ & 0.333 & 39.3 & 33.4 & 12.0 & 15.3 & 100.0 \\
\hline
\end{tabular}

Legend: $\mathrm{T} / \mathrm{Y} / \mathrm{P}=$ Total urban wood waste resource, tons/year/person

Lndfl $=$ Landfill or incineration

Bfuel $=$ Biomass fuel

\section{Energy Production Potential}

The US urban wood waste resource represents a possible substitute for fossil fuels, for example as a cofired fuel in coal-fired power plants. The US consumes about 1,300 MW of electric energy per million people. The urban wood wastes in the 30 metropolitan areas sampled would support the generation of between 5 and 50 MW per million people, or roughly $0.4 \%$ to $4 \%$ of the urban areas' electricity needs. (In most cases, the resources fall in the range of $1 \%$ to $2 \%$ of electricity needs.) The diversion of urban wood wastes from 
land application, landfills, and other forms of disposal into coal-fired power plants could be a significant tool in the national effort to reduce fossil $\mathrm{CO}_{2}$ emissions.

\section{Municipal Solid Waste (MSW) Collection and Disposal}

Most of the 30 metropolitan areas studied have both public and private trash hauling services, and public and private landfills. A few of the 30 metropolitan areas leave all trash hauling and disposal activities to the private sector, and a few others provide essentially all such services through public agencies. All but three of the 30 metropolitan areas offer wood and yard waste collection and recycling programs; some of these programs are much more extensive and aggressive than others. In general, wood and yard wastes collected in municipal recycling programs are ground to mulch, which is used in public areas such as parks and given away or sold to the public. Some of this material is composted, sometimes in combination with biosolids from wastewater treatment plants. Very few private trash haulers or landfill owners separate or recycle wood wastes.

In most of the metropolitan areas studied, separate landfills take MSW and C/D debris. Four of the metropolitan areas dispose of some solid waste in incinerators or waste-toenergy facilities. Tipping fees range from $\$ 16 /$ ton in Lincoln to $\$ 85 /$ ton in the Boston area. The amount of wood entering landfills along with trash is not measured. We have assumed that the amount of wood entering MSW landfills is about 3-5\% of the total MSW by weight, and that the amount of wood entering C/D landfills is about $18-20 \%$ of the total debris by weight.

\section{MSW Wood (Primarily Tree and Yard Waste)}

Four categories of MSW wood were identified in every metropolitan area in this study:

- Wood hauled with trash, as discussed above;

- Municipal yard waste recycling, also discussed above;

- Utility tree trimming; and

- Private tree service companies.

Most utility companies hire specialized tree service companies to handle the tree trimming work along their rights-of-way. One company, Asplundh, and a handful of other large companies have contracts with the utilities in most of the 30 metropolitan areas studied. In contrast, nearly all private tree service companies are very small local firms. Most of the wood generated from tree trimming is given away as mulch and firewood to land owners or others. The amounts are not measured, but can be estimated from the fact that a single tree service crew typically generates about 1,000 tons/year of wood waste.

\section{Industrial Wood Wastes}

The industrial wood wastes in the 30 metropolitan areas come from the following sources:

- Pallet companies (producers and recyclers)

- Truss companies

- Wholesale lumber companies

- Retail lumber companies

- Woodworking companies (e.g., cabinet makers, furniture designers and custom builders, furniture manufacturers, hardwood flooring companies)

The larger pallet and wholesale lumber companies tend to process and market their own wood wastes. Most large communities have wood processing companies that accept industrial wood wastes (and often MSW and C/D wood wastes as well), and convert these 
wastes to products, mulch, or fuel. Retail lumber companies and woodworking companies generally produce very small quantities of wood wastes, and either give them away as firewood or animal bedding or dispose of them in some way.

Tables 4 and 5 summarize the major generators and end uses of MSW wood and industrial wood, respectively, ranked from left to right and top to bottom. These rankings apply to the total wood resources from the 30 metropolitan areas taken together, and are not the same in every area. However, the tables do provide an idea of what the most important sources and uses of MSW wood and industrial wood wastes are in many urban areas.

\section{Table 4}

MSW Wood: Generators and End Uses

Tons/Year/Person

\begin{tabular}{|c|c|c|c|c|c|c|}
\hline End Use & PTS & YWR & HWT & UTT & Total & $\%$ \\
\hline Mulch & 0.047 & 0.047 & & 0.015 & 0.109 & 52.3 \\
\hline Landfill or incineration & 0.008 & & 0.046 & & 0.054 & 25.8 \\
\hline Firewood & 0.017 & & & 0.005 & 0.022 & 10.7 \\
\hline Biomass fuel & 0.015 & & & 0.004 & 0.019 & 9.1 \\
\hline Rural dumping or burning & 0.002 & & & 0.001 & 0.003 & 1.3 \\
\hline Furnish, logs, pulp chips & 0.002 & & & & 0.002 & 0.8 \\
\hline Tot & 0.091 & & & 0.025 & 0.209 & 100.0 \\
\hline Percent of total & 43.8 & 22.5 & 21.9 & 11.8 & 100.0 & \\
\hline
\end{tabular}

Legend: PTS = private tree service companies

YWR $=$ municipal yard waste recycling

HWT $=$ hauled with trash

$\mathrm{UTT}=$ utility tree trimming

\section{Table 5 \\ Industrial Wood: Generators and End Uses \\ Tons/Year/Person}

\begin{tabular}{|c|c|c|c|c|c|c|}
\hline End Use & Pal & Lum & WW & Truss & Total & $\%$ \\
\hline Biomass fuel & 0.008 & 0.005 & & & 0.013 & 26.4 \\
\hline Furnish, logs, pulp chips & 0.007 & 0.005 & & & 0.012 & 25.7 \\
\hline Mulch & 0.008 & 0.003 & & & 0.011 & 23.0 \\
\hline Landfill or incineration & 0.002 & 0.002 & 0.001 & & 0.005 & 11.0 \\
\hline Animal bedding & & 0.003 & & 0.001 & 0.004 & 8.1 \\
\hline Firewood & & 0.001 & 0.001 & & 0.002 & 4.2 \\
\hline Specialty products & 0.001 & & & & 0.001 & 1.5 \\
\hline Total & 0.027 & 0.019 & 0.002 & 0.001 & 0.048 & 100.0 \\
\hline Percent of total & 55.7 & 38.8 & 3.3 & 2.2 & 100.0 & \\
\hline
\end{tabular}

Legend: Pal $=$ pallet companies

Lum $=$ lumber companies

$\mathrm{WW}=$ woodworking companies

Truss $=$ truss companies 


\section{Construction/Demolition Wood Wastes}

The amount of wood waste generated at residential housing job sites is much lower than it was just a few years ago due to the use of prefabricated components that are assembled on site with little or no cutting. Land clearing for new construction sites can be a major source of C/D wood, but the quantities of wood per acre vary dramatically from one area to another. In some areas, land clearing wood is processed to recover logs, fuel, and mulch; but most land clearing contractors simply push and burn the wood. Demolition contractors rarely separate or recover wood from the debris, and generally dispose of it at the lowest cost $\mathrm{C} / \mathrm{D}$ landfill in the area. It was not possible to obtain even rough estimates of the amounts of wood generated by construction contractors, demolition contractors, and land clearing companies. However, rough estimates were developed for the amounts of C/D wood disposed of or converted to various end uses (see the C/D column in Table 2).

\section{Supply Curves}

The data collected on urban wood wastes in the 30 metropolitan areas included the "prices" as well as the quantities of wood wastes. "Price" refers to the net payment or cost incurred by the primary generator of the wood waste. An example of a negative price is a landfill tipping fee. An example of a "zero" price is the mulch or firewood that a tree service company gives to a land owner after trimming his trees. An example of a positive price is the price of biomass fuel generated and sold by a lumber company.

In constructing a supply curve, wood waste quantities are plotted cumulatively along the $\mathrm{x}$ axis, and prices are plotted in ascending order along the y-axis. The result looks like an uneven set of steps. Each step represents a certain number of tons/year at a certain price. The primary purpose of the supply curve is to help answer questions such as "If my power plant offered to accept wood wastes, and set a tipping fee of $\$ 10 /$ ton, how much wood would show up?" Some percentage of the wood in that portion of the supply curve to the left of, or below, $-\$ 10 /$ ton would show up at the power plant.

As an example, Figure 1 and Table 6 present the supply curve for urban wood wastes in the Richmond-Petersburg, Virginia metropolitan area. The table helps explain the data or assumptions contained in the "steps" of the supply curve. For example, the first entry in Table 6 describes 34,000 tons/year of wood waste that are landfilled along with MSW and $\mathrm{C} / \mathrm{D}$ debris in public landfills; the tipping fee is $\$ 50 /$ ton. The last entry in Table 6 describes 108,000 tons/year of pulp chips sold by wholesale lumber companies in the metropolitan area to pulp and paper mills; the price is $\$ 12 /$ ton.

\section{Supply Curve Anatomy}

Four distinct categories of urban wood waste, two or more of which are present in every metropolitan area studied, combine to create the "anatomy" of an urban wood waste supply curve. In ascending order of price (\$/ton), these categories are:

- Wood disposed of in landfills or municipal solid waste $-\$ 85$ to $-\$ 16$ incinerators

- Wood delivered to (or picked up by) processors (private $\quad-\$ 42$ to $-\$ 5$ or public) for recycling

- Wood privately dumped or burned, or informally $-\$ 5$ to $\$ 0$ recycled as mulch or firewood

- Wood processed by its generators and sold as products $\$ 3$ to $\$ 12$ (mulch, biofuel, pulp chips, furnish) 


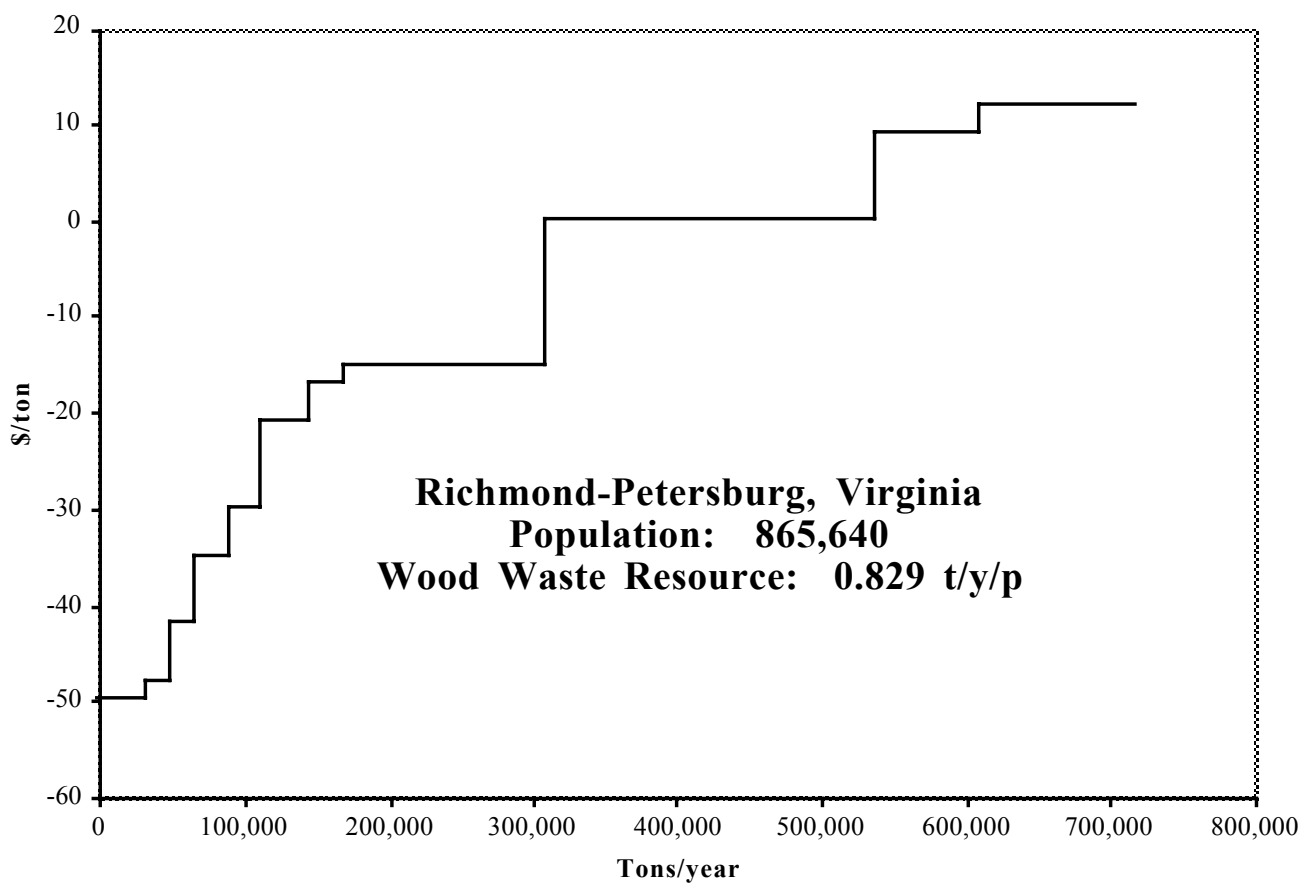

Figure 1. Supply Curve for Urban Wood Wastes in Richmond-Petersburg, Virginia

Table 6

Data and Assumptions Used in Supply Curve for Richmond-Petersburg

Tons/year Cumulative \$/ton $\frac{\text { Assumptions/Comments }}{34,000}$

\begin{tabular}{|c|c|c|c|}
\hline 34,000 & 34,000 & -50 & Landfilled with MSW and C/D - public landfills \\
\hline 15,000 & 49,000 & -48 & Landfilled with MSW and C/D - private landfills \\
\hline 18,000 & 67,000 & -42 & Pallet wood processors - biofuel, animal bd, mulch \\
\hline 24,000 & 91,000 & -35 & Landfilled with MSW and C/D - private landfills \\
\hline 20,000 & 111,000 & -30 & Pallet wood processors - biofuel, animal bd, mulch \\
\hline 33,000 & 144,000 & -21 & Landfilled with MSW and C/D - private landfills \\
\hline 26,000 & 170,000 & -17 & Pallet wood processors - biofuel, animal bd, mulch \\
\hline 140,000 & 310,000 & -15 & Land clearing wood processors - fuel, logs, chips, \\
\hline 228,000 & 538,000 & 0 & Firewood and mulch - given away \\
\hline 72,000 & 610,000 & 9 & Biofuel, animal bedding, mulch - sold \\
\hline 108,000 & 718,000 & 12 & Pulp chips - sold \\
\hline
\end{tabular}

In every metropolitan area, the wood at the bottom of the supply curve is being landfilled (or incinerated, if the area has solid waste incineration facilities). Landfill tipping fees always represent the lowest (most negative) prices for wood waste in an area. In many metropolitan areas, the next set of steps on the supply curve above the "landfill steps" represent wood processors. These companies charge tipping fees somewhat lower than the landfills in the area in order to attract wood wastes. In the Richmond-Petersburg area, 
where there is a wide range of landfill tipping fees ( $\$ 21$ to $\$ 50 /$ ton), some of the wood processor steps are intermingled with some of the landfill steps on the supply curve.

The next step in a wood waste supply curve is the "zero price line." In every metropolitan area studied, some wood (the majority of wood in some cases) is informally recycled, dumped, or burned by its generators. The most common form of this behavior is the conversion of tree trimming wastes into mulch and firewood. In the Richmond-Petersburg area, an estimated 228,000 tons/year of firewood and mulch are given away.

Finally, in some of the metropolitan areas studied (such as Richmond-Petersburg), large lumber mills or other wood products companies produce significant quantities of sawdust and shavings. Some of these areas also have large consumers of wood wastes (usually pulp and paper mills or power plants). In these cases, the lumber mills sell fuel and pulp chips to the paper mills and fuel to the power plants, and a series of "above zero" steps appear on the supply curve. This wood is clearly a portion of the resource that has found a productive use. It is a byproduct rather than a waste.

\section{National Supply Curve}

A national urban wood waste supply curve was constructed from the data gathered in this study as follows:

1. The data from the 30 supply curves were combined together to create a supply curve for the total sample of 30 metropolitan areas. This sample has a population (1990) of 16,962,303 and a total urban wood waste resource of 5,656,710 tons/year (0.333 tons/year/person).

2. The wood waste quantities were multiplied by 11.38 , which is the ratio of the 1990 population of all 281 metropolitan areas in the US $(193,007,670)$ to the population of the 30 metropolitan areas studied $(16,962,303)$.

3. The resulting supply curve was plotted as shown in Figure 2. Note that this supply curve represents the metropolitan areas of the US only, and does not include areas outside the 281 metropolitan areas defined by the Census Bureau in 1990. The total estimated urban wood waste resource in the US is $64,373,000$ tons/year.

The "steps" in the national supply curve appear much smaller than those in the individual cities because the spectrum of tipping fees is much wider. If we assume that the four parts of the national supply curve anatomy are represented by the price ranges below, the approximate percentages of the total urban wood waste resource are as follows:

Wood landfilled
Wood processed
Wood privately dumped
Wood sold by waste generators

$\begin{array}{cr}\text { - \$85 through - } \$ 20 / \text { ton } & 30 \% \\ \text { - \$19 through - \$2/ton } & 22 \% \\ \text { \$0/ton } & 43 \% \\ \text { \$3 through \$24/ton } & 5 \% \\ & 100 \%\end{array}$




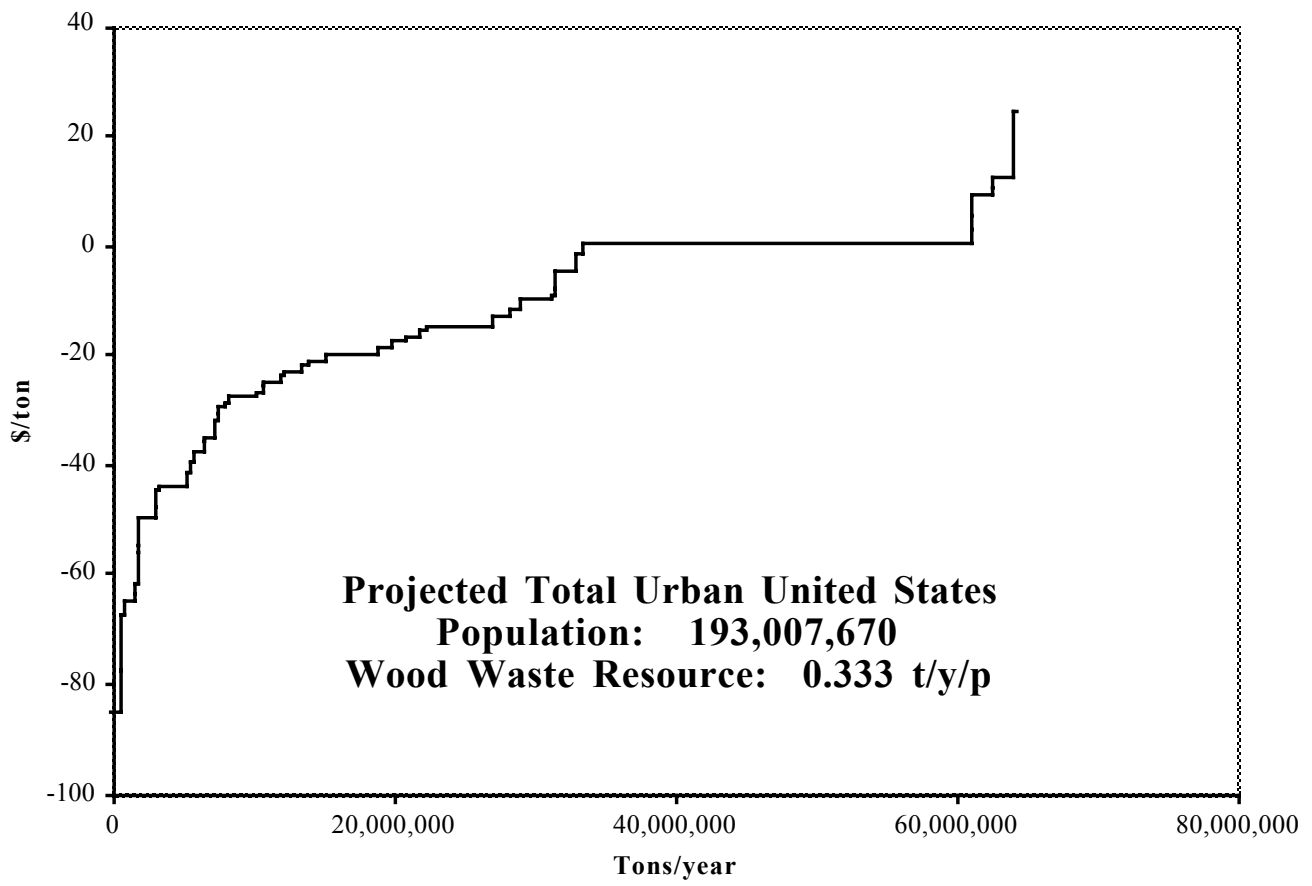

Figure 2. Supply Curve Projected for All Metropolitan Areas in the United States 


\section{A. INTRODUCTION}

\section{Objective}

The National Renewable Energy Laboratory (NREL) stated the following objective in funding this work: "The objective of this work is to develop a cost effective methodology for estimating urban wood waste quantities and values on a state and regional scale for the United States; and implement it to produce state-level urban wood waste data. If successful, this research will provide a replicable methodology for others to use."

\section{Review of Existing Urban Wood Waste Resource Assessments}

There are relatively few published reports that provide data and analyses of urban wood waste resources in the US. It is likely that a large number of privately-sponsored wood waste resource assessments have been done for companies planning or evaluating investments in wood processing or power generation facilities, but these are not available in the public domain. Most of the existing studies were funded by the US Department of Energy through its Regional Biomass Energy Program, and/or by state agencies.

A comment on the use of wet (or green) tons vs. dry tons is necessary. Because most wood waste producers, haulers, and processors generally report quantities in "tons" (i.e., wet tons) and do not know the exact moisture contents, which are quite variable, most studies in the literature simply report data in "tons". This report does the same. Typical moisture contents (wet basis) for urban wood wastes are: 5-20\% moisture for pallets, lumber wastes (e.g., construction/demolition wood), and wastes from secondary wood processors (e.g., furniture manufacturers); and 45-60\% moisture for tree wood and brush.

Actually, many wood waste producers, haulers, and processors report data in cubic yards, or in numbers of truckloads. The conversions from cubic yards to tons are sensitive to the moisture content of the wood, and also to the particle size. Although there are large variations from one load of wood waste to the next, the following factors were used in this work to convert volumetric estimates to weight estimates:

One ton of urban wood waste equals:

- 2 cubic yards of stumps

- 2.5 cubic yards of $\operatorname{logs}$

- 3.3 cubic yards of chips (or shredded or ground wood)

- 5 cubic yards of mixed wood

- 6 cubic yards of tops and brush

US Environmental Protection Agency, "Characterization of Municipal Solid Waste in the United States; 1995 Update". The generation of municipal solid waste (MSW) in 1994 in the US was estimated to be 4.4 pounds/day/person ( 0.803 tons/year/person). After accounting for the amount of MSW recycled or composted, the net amount discarded was estimated to be 3.4 pounds/day/person (0.62 tons/year/person). MSW as defined by the EPA does not include construction and demolition debris. 
C.T. Donovan Associates, Inc., "A Sourcebook on Wood Waste Recovery and Recycling in the Southeast", prepared for the Southeastern Regional Biomass Energy Program, 1994. While this report does not include a resource survey, it does provide a good definition of urban wood waste and its components, which is excerpted here with thanks to Christine Donovan and her associates: "The term urban wood waste refers to used pallets, construction/demolition wood, and other wood that may be commingled with other municipal or commercial solid waste, or may be available as a separate waste material such as tree trimmings from utility right-of-way maintenance activities. The term has not been specifically defined by regulatory agencies or industry groups. Yet, it is widely used as a collective reference to wood waste present in municipal and commercial solid waste."

C.T. Donovan Associates, Inc., "Delaware Waste Biomass Resource Survey", prepared for Delaware Forest Service, 1994. This report characterizes all significant wood waste streams in Delaware: harvested wood waste, mill residue, and solid waste stream wood (equivalent to urban wood waste), as well as post-consumer waste paper and poultry industry waste. The amount of urban wood waste discarded in Delaware was found to be approximately 0.320 tons/year/person.

NEOS Corporation, "Urban Wood Waste Resource Assessment: The State of Indiana", prepared for Indiana Department of Commerce and Great Lakes Regional Biomass Program, 1995. This report presents data on urban wood wastes in the 11 largest metropolitan areas of Indiana, representing about $80 \%$ of the state's population. NEOS surveyed all wood waste generators in these areas (147 primary and 427 secondary wood processors, 46 pallet manufacturers and recyclers, 85 firms in the demolition industry, and 947 urban tree and landscape residue generators); approximately 1,650 generators in all. Telephone surveys were used for secondary wood processors and pallet manufacturers. Mail surveys were used for urban tree residue generators (municipal park and recreation departments, municipal and county tree care divisions, electric utility power line maintenance departments, landscape maintenance/landscape/nursery firms, and excavator/ land clearance firms). In Indiana, urban tree and landscape residues are the largest component in the urban wood waste stream (about 55\%). National estimates, coupled with data on building construction starts and demolition permits issued, were used for the $\mathrm{C} / \mathrm{D}$ wood categories. Construction and demolition industries do not maintain accurate records of wood waste production from their operations. The amount of urban wood waste in Indiana was found to be approximately 0.312 tons/year/person.

Public Policy Associates, "Urban Wood Waste in Michigan: Supply and Policy Issues", prepared by Public Policy Associates for the Council of Great Lakes Governors, Inc. and the US Department of Energy, 1994. Public Policy Associates (PPA) surveyed solid waste and recycling coordinators, wood waste brokers and processors, and urban forestry and landscaping operators in the Detroit, Lansing, Grand Rapids and other southern Michigan metropolitan areas. The report notes that the word "urban" denotes the non-forestry origins of the wood waste; it does not mean that all of the wood waste is literally generated only in urban areas. PPA used a more detailed categorization of urban wood wastes than the other studies. PPA indicated that their estimates reflected significant underreporting, especially in the demolition and tree trimming categories. The statewide urban wood waste estimate was only 0.085 tons/year/person (with individual cities ranging from 0.049 to 0.122 ).

The PPA report also cites the estimates of urban wood waste resources made in previous studies in Illinois (1991), Wisconsin (1993), Michigan (1994), and Minnesota (1992). Each of these studies examined different categories of urban wood wastes. The 1991 Illinois study evaluated the entire wood waste stream and came up with an estimate of 0.131 tons/year/person for the "urban" portion. The 1993 Wisconsin study examined the industrial wood residue stream (excluding sawmills), and arrived at a very high figure of 
0.699 tons/year/person just for this portion of the urban wood waste stream. The 1994 Michigan study surveyed secondary wood manufacturing residue generation, and extrapolated from the survey responses to a statewide estimate of 0.443 tons/year/person. Finally, the 1992 Minnesota study estimated the generation of urban tree residue in the Twin Cities area to be about 0.132 tons/year/person.

M.L. Smith Environmental \& Associates, "Processing and Utilizing Urban Wood Waste and Pallets for Fuel, in Proceedings, Second Biomass Conference of the Americas, Portland, OR, August 21-24, 1995. This conference paper is a summary of work done in 1994 by M.L. Smith for the Great Lakes Regional Biomass Energy Program covering the states of Illinois, Iowa, Minnesota, Ohio, and Wisconsin. Smith found a wide variation in per capita wood waste estimates for those five states ( 0.124 to 0.460 tons/year/person).

C.T. Donovan Associates, Inc., "Wood Waste Available for Fuel in Rhode Island", prepared for Rhode Island Governor's Office of Housing, Energy and Intergovernmental Relations, 1990. This report provides data and analysis on the major components in the wood waste stream, including silviculture and mill wastes in addition to the various components of urban wood waste. The total amount of urban wood waste discarded (available for fuel) was estimated to be 0.237 tons/year/person.

C.T. Donovan Associates, Inc., "Recycling Construction and Demolition Waste in Rhode Island", prepared for Rhode Island Governor's Office of Housing, Energy and Intergovernmental Relations, 1992. This report describes the types and amounts of construction and demolition (C/D) waste generated in Rhode Island, and identifies opportunities for increased reuse and recycling.

NEOS Corporation, "Urban Tree Residues: Results of the First National Inventory", in Proceedings, BIOENERGY '94, the Sixth National Bioenergy Conference, Reno/Sparks, Nevada, October 2-6, 1994. (Work sponsored by the International Society for Arboricultural Research Trust, Allegheny Power Service Corporation, and the National Arborists Foundation.) A mail and telephone survey was performed of commercial tree care firms, municipal/county park and recreation departments and tree care divisions, electric utility power line maintenance organizations, landscape maintenance/landscaper/ nursery firms, and excavator/land clearance firms to determine the quantity of urban tree and landscape residues. NEOS noted the lack of knowledge by industry personnel on the actual volume and characteristics of the residue that they generate. Ninety-five percent of the data reported on the survey forms was estimated (rather than measured and recorded) by the respondents.

Table 7 summarizes the data from the reports mentioned above. Based on the comments of the authors of the various studies, probably the most significant difficulty in urban wood resource estimation is the inherent inaccuracy of the numbers provided by the survey respondents themselves. There is a general lack of record-keeping by urban wood waste generators and haulers, and a tendency for some (e.g., demolition waste haulers and tree trimmers) to underreport or not respond. It is likely that the estimates of urban wood waste resources found in this literature survey are lower than the actual amounts. In addition, it is not likely that any survey methodology could be developed that would produce enough "hard" data to allow for valid statistical analysis. This was one of the questions that we wanted to explore as we began this study. Still, if the practical application of urban wood resource estimates is to assist energy companies in evaluating potential fuel resources, then obtaining accurate estimates of wood waste quantities available in a metropolitan area is not as important as understanding the economics and dynamics of the urban waste wood markets (e.g., the underlying forces that establish prices, costs, and trends). 
Table 7

Data Compilation: Previous Urban Wood Waste Resource Assessments

Tons/Year/Person

\begin{tabular}{|c|c|c|c|c|c|c|}
\hline $\begin{array}{c}\text { State or } \\
\text { Metro Area } \\
\end{array}$ & Reference & Population & $\begin{array}{l}\text { MSW } \\
\text { Wood } \\
\end{array}$ & $\begin{array}{c}\text { Industrial } \\
\text { Wood } \\
\end{array}$ & $\begin{array}{c}\text { C/D } \\
\text { Wood } \\
\end{array}$ & $\begin{array}{l}\text { Total } \\
\text { Wood } \\
\end{array}$ \\
\hline Delaware & Donovan 94 & 666,168 & 0.041 & 0.083 & 0.196 & 0.320 \\
\hline Indianapolis & NEOS 95 & $1,249,822$ & 0.246 & 0.005 & 0.044 & 0.295 \\
\hline Fort Wayne & NEOS 95 & 363,606 & 0.248 & 0.032 & 0.084 & 0.364 \\
\hline Evansville & NEOS 95 & 339,481 & 0.268 & 0.019 & 0.040 & 0.327 \\
\hline Gary/Hammond & NEOS 95 & 711,592 & 0.242 & 0.002 & 0.017 & 0.261 \\
\hline South Bend/Elkhart & NEOS 95 & 403,250 & 0.285 & 0.005 & 0.097 & 0.387 \\
\hline Muncie/Anderson & NEOS 95 & 298,467 & 0.245 & 0.104 & 0.052 & 0.400 \\
\hline Bloomington & NEOS 95 & 267,281 & 0.252 & 0.009 & 0.025 & 0.287 \\
\hline Terre Haute & NEOS 95 & 161,222 & 0.238 & 0.007 & 0.036 & 0.281 \\
\hline Kokomo/Marion & NEOS 95 & 265,375 & 0.242 & 0.009 & 0.012 & 0.264 \\
\hline Richmond & NEOS 95 & 97,966 & 0.251 & 0.000 & 0.055 & 0.306 \\
\hline New Albany & NEOS 95 & 226,686 & 0.267 & 0.022 & 0.032 & 0.321 \\
\hline Detroit & PPA 94 & $4,665,236$ & 0.018 & 0.039 & 0.017 & 0.074 \\
\hline Lansing & PPA 94 & 432,674 & 0.035 & 0.012 & 0.002 & 0.049 \\
\hline Grand Rapids & PPA 96 & 688,399 & 0.062 & 0.056 & 0.005 & 0.122 \\
\hline Other So. Michigan & PPA 96 & $1,098,591$ & 0.018 & 0.067 & 0.038 & 0.122 \\
\hline Illinois & Smith 95 & $9,393,740$ & 0.050 & 0.036 & 0.056 & 0.142 \\
\hline Iowa & Smith 95 & $1,356,707$ & 0.037 & 0.034 & 0.055 & 0.126 \\
\hline Minnesota & Smith 95 & $3,001,486$ & 0.142 & 0.081 & 0.057 & 0.280 \\
\hline Ohio & Smith 95 & $8,756,489$ & 0.254 & 0.051 & 0.155 & 0.460 \\
\hline Wisconsin & Smith 95 & $3,078,217$ & 0.020 & 0.022 & 0.081 & 0.123 \\
\hline Weighted average & & & 0.121 & 0.042 & 0.075 & 0.238 \\
\hline
\end{tabular}

\section{Categories and Key Variables}

Although a number of different categorizations of urban wood wastes exist in the literature, there are basically three major categories, as follows:

- MSW wood

- Hauled with trash

- Municipal yard waste recycling

- Utility tree trimming

- Private tree service companies

- Industrial wood

- Pallet companies (producers and recyclers)

- Truss companies

- Wholesale lumber companies

- Retail lumber companies

- Woodworking companies (e.g., cabinet makers, furniture designers and custom builders, furniture manufacturers, hardwood flooring companies) 
- $\mathrm{C} / \mathrm{D}$ wood

- Demolition contractors

- Land clearing and leveling companies

From a data collection standpoint, the existence of large wood processing companies in a metropolitan area is a mixed blessing. These companies almost always keep their data secret, except for standard price lists. They collect wood wastes from several of the above categories, and often from outside the metropolitan area as well, which tends to blur the lines between the categories and make resource estimation difficult.

The key variables or parameters that impact supply, price, and disposal practices of urban wood waste components are different for each of the three major waste categories:

MSW wood. As a fraction of total urban wood waste resources, MSW wood can range from about $20 \%$ to $90 \%$, with a "typical" value of about $63 \%$. MSW wood includes all types of wood commonly found in mixed residential, commercial, and institutional waste streams, such as wood produced by households and small commercial generators that is typically handled by MSW haulers and disposal facilities. Examples include household yard waste, household remodeling scrap, municipal and utility tree trimmings, and wooden shipping containers (other than pallets) disposed of by retail and grocery stores. The generation rates of these components are primarily functions of population. Differences from one area to another in the tonnages produced per person result from differences in tree populations, growing seasons, rainfall, and economic makeup. In principle, the impacts of these variables could be quantified through the collection and analysis of data. As a practical matter, such precise data collection would be too difficult and expensive to justify.

Industrial wood. Waste wood from pallets and other industrial wood can range from a negligible resource to two thirds of a metropolitan area's wood waste resource, with a "typical" value of about 14\%. Pallet manufacturing and disposal is a direct function of the industrial activity in the area, and is only secondarily related to population. The ideal dependent variable for prediction of industrial wood waste resources would be a measure of economic output for wood-related industries (e.g., pallets, trusses) reported at the metropolitan area level. The US Census Bureau reports such data on a national basis, but not by metropolitan area.

C/D wood. This resource also varies widely from location to location in its contribution to the total -- from about $4 \%$ to $40 \%$, with a "typical" value of about $23 \%$. The generation of $\mathrm{C} / \mathrm{D}$ wood is a function of housing and commercial building construction activity in an area. In residential construction at least, the amount of wood waste generated at job sites has been dropping dramatically as the industry has adopted prefabricated components that are assembled on site with little or no cutting. Land clearing for new construction sites can be a major source of C/D wood, but the quantities of wood per acre vary dramatically from one area to another. Ideally, the prediction of $\mathrm{C} / \mathrm{D}$ wood resources would be based on a combination of variables, including building permits, demolition permits, and possibly population. One of the objectives in this study was to see if these variables could be used to help predict C/D wood resources.

\section{Sample of US Metropolitan Areas}

The United States Office of Management and Budget (OMB) defines metropolitan areas according to published standards that are applied to Census Bureau data. The general concept of a metropolitan area is that of a core area containing a large population nucleus, together with adjacent communities having a high degree of economic and social integration 
with that core. The current (1996) standards provide that each newly qualifying metropolitan area must include at least one city with 50,000 or more inhabitants, or a Census Bureau-defined urbanized area (of at least 50,000 inhabitants) and a total metropolitan population of at least 100,000 (75,000 in New England).

The Census Bureau report "State and Metropolitan Area Data Book 1991" (based on the 1990 census) lists 281 metropolitan areas in the United States (See Appendix A). The total 1990 population of the 281 metropolitan areas in the US was 193,007,670, which is $77.4 \%$ of the total July 1, 1990 US population of 249,397,990. A sample of 30 metropolitan areas was selected randomly for this study. The initial sample was reviewed to make sure it reflected a good cross-section of the nation geographically, and that it was representative of the total group of 281 metropolitan areas in terms of size distribution. Three substitutions were made for these reasons, resulting in the sample of 30 metropolitan areas shown in Table 8 . Table 9 shows how the sample of 30 compares to the total of 281 metropolitan areas in size distribution.

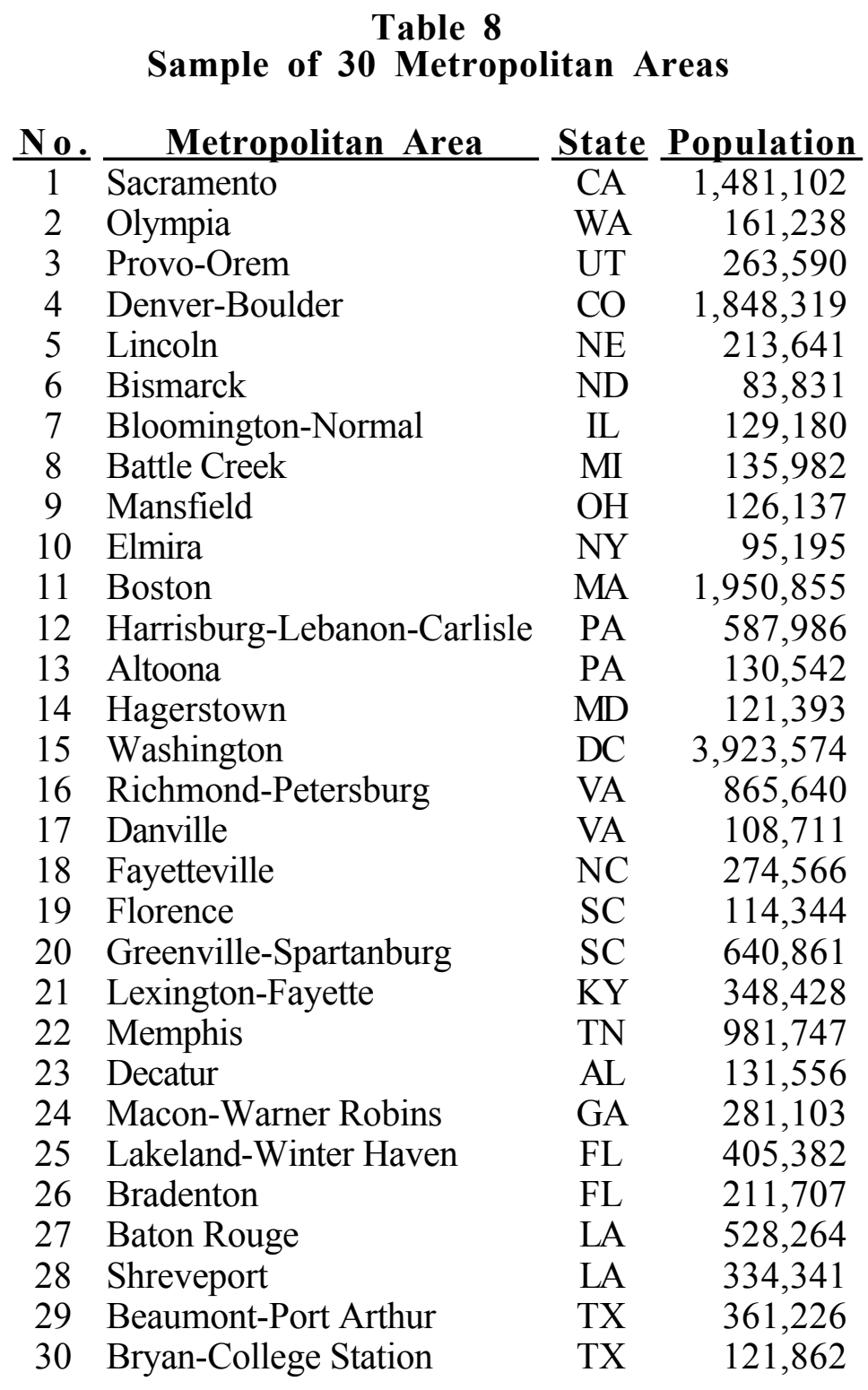


Table 9

Size Distributions: Sample of 30 and 281 US Metropolitan Areas

No. of metro areas with population:

$$
>1,000,000
$$

$500,000-1,000,000$

$200,000-500,000$

$125,000-200,000$

$<125,000$

Total

Average population

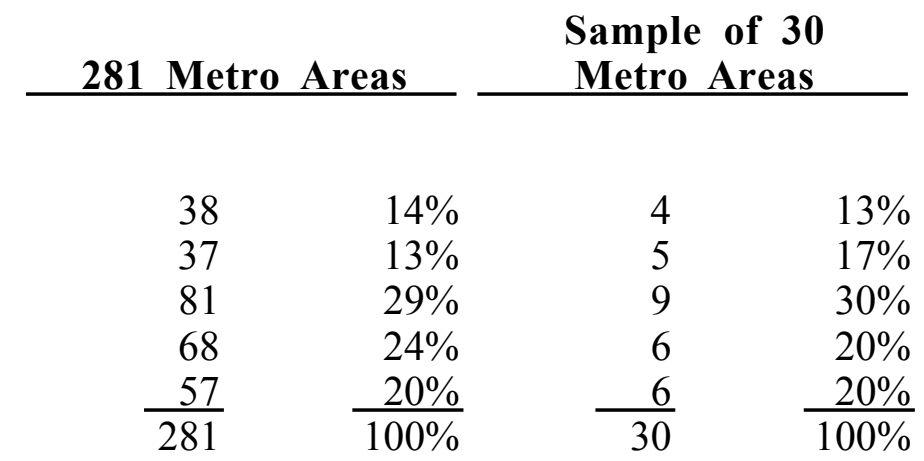

686,860

565,410

\section{Methodology}

I traveled by personal car to all 30 cities in the order shown in Table 8 , starting in October 1997 and finishing in March 1998. I spent 2-5 days gathering data in each city, mostly by telephone from motel rooms. I was able to make use of local resources such as yellow pages, libraries, Chambers of Commerce, and government agencies. Spending time in each area helped provide an "on-the-ground" perspective to the study, including site visits and meetings with key wood waste managers, that hopefully created tangible benefits in the quality of the data and interpretation. The methodology used in this study can easily be replicated by myself or others, entirely by telephone and without personal visits. The availability of yellow pages and other resources on the Internet makes the initial step of obtaining names and numbers relatively easy and inexpensive.

Upon completion of data-gathering for each successive group of five metropolitan areas, I compiled all the data for those five cities into a report and submitted each report to the NREL Technical Monitor, Shaine Tyson. This allowed for feedback and redirection as the study proceeded, and made compilation of the final report and interpretation of the total package of results an easier task.

Although the sample of 30 urban areas was selected randomly, the interview methodology was deliberately not random. In many waste-related industry segments and urban areas, a small number of dominant firms and/or government agencies control a very large share ( $80 \%$ or more) of the business. Managers of these businesses and agencies are the most important people to get to the phone, and my effort was directed at this goal.

In each city, I started by making complete lists from the government pages and the yellow pages of every agency and company that appeared to be relevant. Table 10 shows the yellow pages categories from which I copied all names and numbers in every city. In a large city this process alone took eight or more hours before a single phone call was made. Companies that pay for extra-large ads in the yellow pages were noted. The calls began with government agencies; usually one or more agency (city, county, or state) compiles relevant statistics and/or directs parts of the waste management process. In addition to providing data, these people almost always were helpful in naming dominant companies, and sometimes naming key managers to contact. I followed all such leads to their logical conclusions, and then began the process of calling all the companies listed in the yellow pages, starting with the "big ad" companies first. I found that input from small companies 
was very useful and often gave clues to what "really goes on", as opposed to the "party line" type of information typically provided by larger companies. The percentage of calls completed to small companies was low, however, because the manager/owner was usually at a customer's job site and his/her phone was answered by a voicemail service or a spouse. Early in the morning or around the dinner hour were the best times to reach many of the small company owners.

\title{
Table 10 \\ Yellow Pages Categories Used to Develop Contact Lists
}

\author{
MSW Wood \\ City and County Government Offices (Solid Waste, Recycling) \\ Garbage Collection and/or Rubbish Removal \\ Landfills \\ Tree Service \\ Electric Companies \\ Universities \\ Industrial Wood \\ Pallets \& Skids \\ Lumber-Wholesale \\ Lumber-Retail \\ Cabinet Makers \\ Furniture Designers \& Custom Builders \\ Furniture Manufacturers \\ Woodworking \\ Recycling Centers \\ Trusses-Construction \\ Hardwoods \\ C/D Wood \\ Demolition Contractors \\ Land Clearing \& Leveling \\ City and County Government Offices \\ Landfills
}

I had developed a set of survey forms and questions, with different questions for different types of businesses or agencies (see Appendix B). These forms were useful as prompters, but I did not adhere to them strictly. I stated very briefly that I was collecting data on urban wood wastes for the US Department of Energy, and then asked a simple lead-off question such as "What do you do with the wood from tree trimmings and removals?" (to a tree service company manager). In most cases I was able to engage in a friendly conversation while obtaining whatever quantitative information the person could share.

As discussed earlier, some wood waste generators do not keep records, and it was necessary to use estimation techniques. For example, tree service companies almost never measure the quantities of wood waste they generate; because they dispose of most of it privately by giving it away as firewood and mulch, they have no need to know what the quantities are. After talking to enough tree service companies and developing estimates with their help based on the number of truckloads they fill per day or week, I became convinced of one fact that is consistent from coast to coast: on the average, one tree service crew generates about 1,000 tons/year of wood waste. With that information, the questions 
for a tree service company boil down to two: 1. "What do you do with the wood from tree trimmings and removals?"; and 2. "How many crews do you operate?" I also learned that the vast majority of tree service companies in the US are small companies that normally operate with one crew. Most cities have a small number of larger tree service companies that operate with two to six crews. (This is not counting the companies that provide tree service to utilities, which are large, nationwide firms [e.g., Asplundh] that specialize in that business.) So a quick and dirty way of estimating the amount of wood waste generated by private tree service companies in a metropolitan area is to count the number of companies in the phone book (say, for example, 20), add about $20 \%$ to this number to estimate the number of crews operating in the area (e.g., 24), and multiply by 1,000 to get tons/year (e.g., 24,000). By making 20 phone calls to these companies, which takes two hours or less, this information can be refined and any unusual local practices can be identified.

The above explanation was given in order to make clear that the wood waste generation estimates in this report are not all based on hard, measured data. On the other hand, they are probably the best estimates that can be developed; they are certainly better than estimates derived from normal mail or phone survey responses. Other examples of estimating techniques used in this study are:

- The amount of wood entering landfills along with the trash is not usually measured. By talking to many landfill managers, and learning the results of sampling and analysis programs some solid waste agencies had conducted, I concluded that the amount of wood entering MSW landfills is approximately:

- $3 \%$ of the total MSW by weight, in areas where wood and yard waste separation and recycling are practiced; and

- $5 \%$ of the total MSW by weight in other areas.

- The amount of wood in C/D debris entering C/D landfills is most commonly described by landfill managers as "about half." This turns out to mean about $50 \%$ wood and $50 \%$ brick, rock, asphalt, etc., by volume. Because wood wastes have much lower densities than these other inert components, $50 \%$ by volume works out to be about $18-20 \%$ wood by weight.

- For tree trimming along utility rights-of-way, many of the contract tree service managers or utility tree trimming managers responded with good, quantitative data. Others, however, did not respond at all. In those cases, I developed factored estimates based on the data from other areas, adjusted by population.

- For many pallet companies and lumber companies, the best information available was, for example, that "about three truckloads per week of wood scraps are hauled away to XYZ." By estimating the average size of each truckload based on the description of the trucks (e.g., about 10 cubic yards), and assuming that about 5 cubic yards of mixed wood scraps equals one ton, this information results in an estimate of about 300 tons/year for that particular generator.

- Woodworking companies (cabinet makers, etc.) are mostly very small companies, producing small quantities of wood scraps that are used by family and friends or given away as firewood. By going through calculations similar to those for the pallet and lumber companies, I found that small woodworking firms typically generate somewhere between 5 and 20 tons/year of wood wastes each.

Immediately after each phone call, I performed calculations such as the above and developed my best estimate of each respondent's wood waste generation rate. Later (sometimes two or three weeks later), when I prepared the draft report on each group of five metropolitan areas, I combined all of these estimates with other data I had obtained to 
produce the urban wood resource estimates for each metropolitan area. In this process, I also took into account the non-respondents. For example, I might have obtained useful information from 15 tree service companies out of 40 in a particular area, but the estimate I generated was for all 40 companies. When the estimates were completed for all 30 cities, I went back over the entire set, checking carefully for consistency of calculation methods and assumptions. Then I performed some statistical analysis on the complete set of data, as discussed in Section B.

In addition to the data and estimates on wood waste quantities, I obtained as much information as possible in each metropolitan area about tipping fees and other prices charged for handling or disposing of all types of wood wastes. Although this information was often sketchy or incomplete, I used it to assign prices or price ranges to all the major classes of wood wastes in each area. From this information I constructed supply curves, as discussed in Section C. 


\section{B. OVERVIEW OF URBAN WOOD RESOURCE DATA}

\section{Urban Wood Resources}

Tables 11 and 12 summarize the data collected on urban wood resources from 30 metropolitan areas in the US during the period from October 1997 to March 1998. Table 11 shows the data for each metropolitan area in tons/year; Table 12 shows the same data on a per capita basis, in tons/year/person. (Tons include the moisture contained in wood, which can vary from about $10 \%$ in furniture or pallets to about $60 \%$ in tree trimmings.)

The numbers in front of the metropolitan areas represent the order in which the areas were visited, and correspond to the subsection numbers in Section D, the part of the report describing the metropolitan areas' wood resources. City names followed by dashes indicate that additional cities are included in the official name of the metropolitan area (e.g., Provo-Orem). As a shortcut in the following discussion, the word "city" is used interchangeably with "metropolitan area", even though this is not strictly correct.

\section{Statistical Analysis of the Data}

Appendix C presents a series of regression plots and statistical analyses. The first six plots analyze the wood resource data from the full set of 30 cities. The next six plots analyze the wood resource data from 28 cities, with two "outliers" removed, as discussed below. All of the regression equations were specified to go through the origin, based on the assumption that a city with zero population would generate no urban wood wastes.

The first four regression plots on wood resources in the full set of 30 cities simply use population as the independent variable and the amount of wood (MSW, industrial, C/D, and total) as the dependent variable. Visual examination of the plots shows that the regression lines fall below most of the data points, instead of having approximately equal numbers of data points above and below the regression lines. In addition, the regression coefficients (which are in units of tons/year/person) are significantly lower than the weighted average values of the wood resources in tons/year/person shown in Table 12. The reason appears to be the very low quantity of wood resources found in the largest city, Washington, DC. This single data point at the far right of each plot "drags down" the slopes (coefficients) of the regression lines.

Another apparent outlier (this one on the high side) is Richmond, Virginia, with a population of 865,640 . Richmond's per capita urban wood resources are at or near the top in all four categories (see Table 12).

Additional regression plots were generated with the data for Washington, DC and Richmond, VA removed; these plots are labeled "28 Cities". The improvements in the fit of the regression lines to the data are obvious from examining the plots, and from comparing the regression coefficients and r-squared values, as shown in Table 13. 
Using the regression coefficients from the 28-city sample, and rounding off to reflect a reasonable number of significant digits, the urban wood resources of a metropolitan area, region, state, or the US as a whole can be predicted from the following simple equations:

- $\mathrm{MSW}$ wood, tons/year $=0.20 \times$ population

- Industrial wood, tons/year $=0.04 \times$ population

- $\mathrm{C} / \mathrm{D}$ wood, tons/year $=0.09 \times$ population

- Total urban wood, tons/year $=0.33 \times$ population

Table 11

Urban Wood Resources in 30 Metropolitan Areas, Tons/Year

\begin{tabular}{|c|c|c|c|c|c|c|c|}
\hline No. & Metro Area & 120 & ion & $\begin{array}{l}\text { MSW } \\
\text { Wood }\end{array}$ & $\begin{array}{c}\text { Industrial } \\
\text { Wood }\end{array}$ & $\begin{array}{c}\text { C/D } \\
\text { Wood }\end{array}$ & $\begin{array}{l}\text { Total } \\
\text { Wood }\end{array}$ \\
\hline 1 & Sacramento & $\overline{\mathrm{CA}}$ & $1,481,102$ & 328,000 & 46,000 & 71,000 & 445,000 \\
\hline 2 & Olympia & WA & 161,238 & 66,000 & 10,400 & 5,000 & 81,400 \\
\hline 3 & Provo- & UT & 263,590 & 70,000 & 3,900 & 13,000 & 86,900 \\
\hline 4 & Denver- & $\mathrm{CO}$ & $1,848,319$ & 341,000 & 78,000 & 160,000 & 579,000 \\
\hline 5 & Lincoln & $\mathrm{NE}$ & 213,641 & 66,700 & 1,900 & 25,000 & 93,600 \\
\hline 6 & Bismarck & ND & 83,831 & 14,000 & 700 & 5,000 & 19,700 \\
\hline 7 & Bloomington- & IL & 129,180 & 34,800 & 12,200 & 2,000 & 49,000 \\
\hline 8 & Battle Creek & MI & 135,982 & 26,700 & 13,140 & 2,000 & 41,840 \\
\hline 9 & Mansfield & $\mathrm{OH}$ & 126,137 & 20,000 & 14,750 & 2,000 & 36,750 \\
\hline 10 & Elmira & NY & 95,195 & 12,800 & 4,220 & 8,600 & 25,620 \\
\hline 11 & Boston & MA & $1,950,855$ & 362,000 & 61,000 & 220,000 & 643,000 \\
\hline 12 & Harrisburg- & PA & 587 & 93,000 & 28,100 & 23,000 & 144,100 \\
\hline 13 & Altoona & PA & 12 & 24,400 & 28,300 & 3,400 & 56,100 \\
\hline 14 & Hagerstown & $\mathrm{MD}$ & 121,393 & 36,000 & 4,200 & 3,200 & 43,400 \\
\hline 15 & Washington & DC & $3,923,574$ & 536,000 & 3,000 & 75,000 & 614,000 \\
\hline 16 & Richmond- & VA & 865,640 & 257,000 & 245,000 & 216,000 & 718,000 \\
\hline 17 & Danville & VA & 10 & 18,000 & 53,000 & 8,000 & 79,000 \\
\hline 18 & Fayetteville & $\mathrm{NC}$ & 274,566 & 61,600 & 6,100 & 20,600 & 88,300 \\
\hline 19 & Florence & $\mathrm{SC}$ & 114,344 & 25,200 & 4,000 & 2,000 & 31,200 \\
\hline 20 & Greenville- & $\mathrm{SC}$ & 640,861 & 191,000 & 26,000 & 67,000 & 284,000 \\
\hline 21 & Lexington- & $\mathrm{KY}$ & 28 & 79,000 & 5,000 & 13,000 & 97,000 \\
\hline 22 & Memphis & $\mathrm{TN}$ & 47 & 151,000 & 70,000 & 150,000 & 371,000 \\
\hline 23 & Decatur & $\mathrm{AL}$ & 131,556 & 30,000 & 18,000 & 8,000 & 56,000 \\
\hline 24 & Macon- & GA & 281,103 & 75,000 & 7,500 & 15,000 & 97,500 \\
\hline 25 & Lakeland- & $\mathrm{FL}$ & 405 & 138,000 & 46,000 & 28,000 & 212,000 \\
\hline 26 & Bradenton & $\mathrm{FL}$ & 211,707 & 114,000 & 4,500 & 20,000 & 138,500 \\
\hline 27 & Baton Rouge & LA & 528,264 & 163,000 & 11,000 & 85,000 & 259,000 \\
\hline 28 & Shreveport & LA & 334,341 & 82,000 & 6,800 & 20,000 & 108,800 \\
\hline 29 & Beaumont- & TX & 361,226 & 102,000 & 5,700 & 15,000 & 122,700 \\
\hline 30 & Bryan- & $\mathrm{TX}$ & 121,862 & 27,000 & 300 & 7,000 & 34,300 \\
\hline
\end{tabular}


Table 12

Urban Wood Resources in 30 Metropolitan Areas, Tons/Year/Person

\begin{tabular}{|c|c|c|c|c|c|c|c|}
\hline No. & Metro Area & State & Population & $\begin{array}{l}\text { MSW } \\
\text { Wood } \\
\end{array}$ & $\begin{array}{c}\text { Industrial } \\
\text { Wood }\end{array}$ & $\begin{array}{c}\text { C/D } \\
\text { Wood } \\
\end{array}$ & $\begin{array}{l}\text { Total } \\
\text { Wood }\end{array}$ \\
\hline 1 & Sacramento & $\overline{\mathrm{CA}}$ & $1,481,102$ & 0.221 & 0.031 & 0.048 & 0.300 \\
\hline 2 & Olympia & WA & 161,238 & 0.409 & 0.065 & 0.031 & 0.505 \\
\hline 3 & Provo- & UT & 263,590 & 0.266 & 0.015 & 0.049 & 0.330 \\
\hline 4 & Denver- & $\mathrm{CO}$ & $1,848,319$ & 0.184 & 0.042 & 0.087 & 0.313 \\
\hline 5 & Lincoln & $\mathrm{NE}$ & 213,641 & 0.312 & 0.009 & 0.117 & 0.438 \\
\hline 6 & Bismarck & ND & 83,831 & 0.167 & 0.008 & 0.060 & 0.235 \\
\hline 7 & Bloomington- & IL & 129,180 & 0.269 & 0.094 & 0.015 & 0.379 \\
\hline 8 & Battle Creek & MI & 135,982 & 0.196 & 0.097 & 0.015 & 0.308 \\
\hline 9 & Mansfield & $\mathrm{OH}$ & 126,137 & 0.159 & 0.117 & 0.016 & 0.291 \\
\hline 10 & Elmira & NY & 95,195 & 0.134 & 0.044 & 0.090 & 0.269 \\
\hline 11 & Boston & MA & $1,950,855$ & 0.186 & 0.031 & 0.113 & 0.330 \\
\hline 12 & Harrisburg- & PA & 587,986 & 0.158 & 0.048 & 0.039 & 0.245 \\
\hline 13 & Altoona & PA & 130,542 & 0.187 & 0.217 & 0.026 & 0.430 \\
\hline 14 & Hagerstown & $\mathrm{MD}$ & 121,393 & 0.297 & 0.035 & 0.026 & 0.358 \\
\hline 15 & Washington & $\mathrm{DC}$ & $3,923,574$ & 0.137 & 0.001 & 0.019 & 0.156 \\
\hline 16 & Richmond- & VA & 865,640 & 0.297 & 0.283 & 0.250 & 0.829 \\
\hline 17 & Danville & VA & 108,711 & 0.166 & 0.488 & 0.074 & 0.727 \\
\hline 18 & Fayetteville & $\mathrm{NC}$ & 274,566 & 0.224 & 0.022 & 0.075 & 0.322 \\
\hline 19 & Florence & $\mathrm{SC}$ & 114,344 & 0.220 & 0.035 & 0.017 & 0.273 \\
\hline 20 & Greenville- & $\mathrm{SC}$ & 640,861 & 0.298 & 0.041 & 0.105 & 0.443 \\
\hline 21 & Lexington- & $\mathrm{KY}$ & 348,428 & 0.227 & 0.014 & 0.037 & 0.278 \\
\hline 22 & Memphis & $\mathrm{TN}$ & 981,747 & 0.154 & 0.071 & 0.153 & 0.378 \\
\hline 23 & Decatur & $\mathrm{AL}$ & 131,556 & 0.228 & 0.137 & 0.061 & 0.426 \\
\hline 24 & Macon- & GA & 281,103 & 0.267 & 0.027 & 0.053 & 0.347 \\
\hline 25 & Lakeland- & $\mathrm{FL}$ & 405,382 & 0.340 & 0.113 & 0.069 & 0.523 \\
\hline 26 & Bradenton & $\mathrm{FL}$ & 211,707 & 0.538 & 0.021 & 0.094 & 0.654 \\
\hline 27 & Baton Rouge & LA & 528,264 & 0.309 & 0.021 & 0.161 & 0.490 \\
\hline 28 & Shreveport & LA & 334,341 & 0.245 & 0.020 & 0.060 & 0.325 \\
\hline 29 & Beaumont- & TX & 361,226 & 0.282 & 0.016 & 0.042 & 0.340 \\
\hline 30 & Bryan- & $\mathrm{TX}$ & 121,862 & 0.222 & 0.002 & 0.057 & 0.281 \\
\hline & \multicolumn{3}{|c|}{ Weighted average } & 0.209 & 0.048 & 0.076 & 0.333 \\
\hline
\end{tabular}

The equations for MSW wood and total urban wood have a considerably higher confidence level than the equations for industrial and C/D wood. This is to be expected, because MSW wood is primarily a function of population. Total wood turns out to be mostly ( $\sim 60 \%)$ MSW wood; in addition, it appears that the relatively wide variations in industrial wood and C/D wood (which depend more on local economic factors than on population) tend to cancel each other out to some degree when the data for a metropolitan area are aggregated. For the 28-city sample, the r-squared values for both MSW wood and total wood are greater than 0.9 , while those for $\mathrm{C} / \mathrm{D}$ wood and industrial wood are lower. 
Table 13

Regression Coefficients: 30 vs. 28 Cities

\begin{tabular}{|c|c|c|c|c|}
\hline & $\begin{array}{l}\text { MSW } \\
\text { Wood }\end{array}$ & $\begin{array}{l}\text { Industrial } \\
\text { Wood }\end{array}$ & $\begin{array}{l}\text { C/D } \\
\text { Wood }\end{array}$ & $\begin{array}{r}\text { Total } \\
\text { Wood }\end{array}$ \\
\hline \multicolumn{5}{|l|}{$\underline{30 \text { Cities }}$} \\
\hline Weighted average, tons/yr/person & 0.209 & 0.048 & 0.076 & 0.333 \\
\hline Regression coefficient, $\mathrm{t} / \mathrm{y} / \mathrm{p}$ & 0.170 & 0.025 & 0.057 & 0.251 \\
\hline $\mathrm{R}$ squared & 0.857 & -0.071 & 0.314 & 0.592 \\
\hline \multicolumn{5}{|l|}{28 Cities } \\
\hline Weighted average, tons/yr/person & 0.226 & 0.047 & 0.082 & 0.355 \\
\hline Regression coefficient, $\mathrm{t} / \mathrm{y} / \mathrm{p}$ & 0.203 & 0.039 & 0.091 & 0.333 \\
\hline R squared & 0.906 & 0.558 & 0.832 & 0.953 \\
\hline
\end{tabular}

In theory, the regression equation for industrial wood should use a measure of local industrial output (such as the annual sales in certain SIC codes) as the independent variable, instead of population. I was unable to find conveniently available data on such a measure in published reports. The US Census Bureau collects and publishes these types of data, but I was unable to find any reports that provide exactly what is needed here: a measure of economic output for wood-related industries (e.g., pallets, trusses) reported at the metropolitan area level. This search included a thorough search of the Census Bureau web site, and discussions with Census Bureau personnel.

Similarly, the regression equation for C/D wood should use a measure (or measures) of construction and demolition activity (e.g., building permits, demolition permits) as the independent variable(s), instead of population. The Census Bureau does publish a monthly report on housing permits ("new privately owned housing units authorized"), by metropolitan area. The December 1997 report showed the preliminary annual (1997) total number of permits for each metropolitan area in our sample (see Table 14). Because the Census Bureau has redefined three of the metropolitan areas recently, I adjusted their 1997 housing permit data (using population) for the following metropolitan areas: Battle Creek, Boston, and Bradenton.

The fifth and sixth regression plots in both the 30-city and 28-city sets in Appendix C examine the usefulness of the housing permit data as a predictive variable for $\mathrm{C} / \mathrm{D}$ wood resources. Although housing permits correlate reasonably well with population, this measure (housing permits) on its own is not a good predictor of C/D wood resources. Wood debris is produced from the construction of (and land clearing for) commercial buildings, not just housing units. The amount of demolition wood debris is not necessarily related to the number of housing permits; demolition permit data are no longer collected by the Census Bureau. Finally, it should be recognized that the $C / D$ wood resource data in this study (or any other study, for that matter) are really not "data", but rough estimates based on rules of thumb (e.g., 20 weight $\%$ of C/D debris entering landfills is assumed to be wood). In some cities, data are not available on $\mathrm{C} / \mathrm{D}$ debris generated or disposed of; generally, in such cases I assumed a certain portion of the total solid waste entering landfills to be $\mathrm{C} / \mathrm{D}$ debris, and further assumed a certain portion of that to be wood. The net result of all these considerations is that the $\mathrm{C} / \mathrm{D}$ wood data appear to correlate more closely to population than they do to housing permits (especially for the 28-city sample). 
Table 14

Housing Permits and C/D Wood Resources in 30 Metropolitan Areas

\begin{tabular}{|c|c|c|c|c|c|}
\hline No. & Metro Area & State & Population & $\begin{array}{c}\text { Housing } \\
\text { Permits }\end{array}$ & $\begin{array}{c}\text { C/D } \\
\text { Wood }\end{array}$ \\
\hline 1 & Sacramento & $\overline{\mathrm{CA}}$ & $1,481,102$ & 9,807 & 71,000 \\
\hline 2 & Olympia & WA & 161,238 & 1,377 & 5,000 \\
\hline 3 & Provo- & UT & 263,590 & 2,885 & 13,000 \\
\hline 4 & Denver- & $\mathrm{CO}$ & $1,848,319$ & 24,728 & 160,000 \\
\hline 5 & Lincoln & $\mathrm{NE}$ & 213,641 & 2,185 & 25,000 \\
\hline 6 & Bismarck & ND & 83,831 & 780 & 5,000 \\
\hline 7 & Bloomington- & IL & 129,180 & 925 & 2,000 \\
\hline 8 & Battle Creek & MI & 135,982 & 588 & 2,000 \\
\hline 9 & Mansfield & $\mathrm{OH}$ & 126,137 & 583 & 2,000 \\
\hline 10 & Elmira & NY & 95,195 & 46 & 8,600 \\
\hline 11 & Boston & MA & $1,950,855$ & 7,478 & 220,000 \\
\hline 12 & Harrisburg- & PA & 587,986 & 2,411 & 23,000 \\
\hline 13 & Altoona & PA & 130,542 & 51 & 3,400 \\
\hline 14 & Hagerstown & $\mathrm{MD}$ & 121,393 & 601 & 3,200 \\
\hline 15 & Washington & $\mathrm{DC}$ & $3,923,574$ & 30,249 & 75,000 \\
\hline 16 & Richmond- & VA & 865,640 & 7,420 & 216,000 \\
\hline 17 & Danville & VA & 108,711 & 382 & 8,000 \\
\hline 18 & Fayetteville & $\mathrm{NC}$ & 274,566 & 1,425 & 20,600 \\
\hline 19 & Florence & $\mathrm{SC}$ & 114,344 & 705 & 2,000 \\
\hline 20 & Greenville- & $\mathrm{SC}$ & 640,861 & 6,589 & 67,000 \\
\hline 21 & Lexington- & $\mathrm{KY}$ & 348,428 & 3,803 & 13,000 \\
\hline 22 & Memphis & $\mathrm{TN}$ & 981,747 & 8,067 & 150,000 \\
\hline 23 & Decatur & $\mathrm{AL}$ & 131,556 & 363 & 8,000 \\
\hline 24 & Macon- & GA & 281,103 & 1,869 & 15,000 \\
\hline 25 & Lakeland- & FL & 405,382 & 3,367 & 28,000 \\
\hline 26 & Bradenton & $\mathrm{FL}$ & 211,707 & 2,726 & 20,000 \\
\hline 27 & Baton Rouge & LA & 528,264 & 1,469 & 85,000 \\
\hline 28 & Shreveport & LA & 334,341 & 773 & 20,000 \\
\hline 29 & Beaumont- & TX & 361,226 & 432 & 15,000 \\
\hline 30 & Bryan- & TX & 121,862 & 1,216 & 7,000 \\
\hline
\end{tabular}

With regard to the removal of Washington, DC and Richmond, VA from the sample, it is possible that the apparent ultra-low resource in Washington and ultra-high resource in Richmond might be related. The two areas are only about 75 miles apart, and given the nature of these two metropolitan areas Richmond would tend to collect and process some of Washington's wood waste.

This observation about Washington, DC and Richmond leads to a more general reflection about the findings of this study. It is possible that the urban wood resource estimates in this study represent the amounts of wood processed in a metropolitan area better than they represent the amounts generated in that area. This may be a structural bias in the survey technique used, which tended (for good reasons) to focus more heavily on the large waste disposal and wood processing entities than on the multitude of small waste generators, who generally do not know how much wood waste they produce or where it goes. 


\section{SUPPLY CURVES}

\section{Supply Curves - Construction and Purpose}

The data collected on urban wood wastes in the 30 metropolitan areas included the "prices" as well as the quantities of wood wastes whenever possible. "Price" refers to the net payment or cost incurred by the primary generator of the wood waste; it does not refer to the retail price of a final product such as mulch. It is the opportunity cost, or avoided cost, of the raw waste wood as it enters a processing or disposal system or sequence. Negative prices represent cases in which tipping fees, processing costs, and/or transport costs exceed revenues, if any, to the primary generator. The simplest example of a negative price is the fee (in dollars per ton) that a wood waste generator pays to have a load of waste wood hauled away. An example of a "zero" price is the mulch or firewood that a tree service company gives to a land owner after trimming his trees. An example of a positive price is the amount (in dollars per ton) paid by a pulp mill or power plant for sawdust or shavings to a lumber company that generated the waste.

Given a set of quantities and prices for wood wastes in a metropolitan area, it is possible to construct a supply curve. The quantities are plotted in cumulative fashion along the $\mathrm{x}$-axis, and the prices are plotted in ascending order along the y-axis. Rather than a smooth curve or line, the result looks like an uneven set of steps. This is partially an artifact of the data collection process and the inevitable assumptions that must be made, but it does reflect the real workings of the wood waste economy. For example, all of the wood contained in a certain class of solid waste that enters a landfill pays a certain tipping fee. This appears on the supply curve as a horizontal step (a certain number of tons/year at a certain price).

The primary purpose, or value, of the supply curve is to help answer questions such as "If my power plant offered to accept wood wastes of certain types, and set a tipping fee of \$10/ton, how much wood would show up?" A simplistic answer would be found by drawing a horizontal line across the supply curve at $-\$ 10 /$ ton, and reading the number of tons/year at the intersection of that line with the supply curve. In theory, all of the wood waste generators who are currently paying more than $\$ 10 /$ ton to dispose of their wood wastes would save money by bringing it to the power plant and paying the $\$ 10 /$ ton tipping fee. In practice, however, there is "friction" in the economy: some wood waste generators may not find out about the power plant's offer; others may find out but not want to bother; and others may not realize that their wood waste could be separated from the other solid wastes they are sending to the landfill. Still, some percentage of the wood in that portion of the supply curve to the left of, or below, $-\$ 10 /$ ton would show up at the power plant.

The supply curves for the 30 metropolitan areas are presented in Section D at the end of each of the metropolitan area reports. It is suggested that the reader spend a few minutes looking at them before returning to this discussion. To make the "lookup" process easier, references to metropolitan areas in the following discussion include the number assigned to each city (e.g., 1-Sacramento or 30-Bryan-). ${ }^{1}$

\footnotetext{
${ }^{1}$ Metropolitan areas with multiple city names are indicated by a dash after the first city's name for brevity. For example, Bryan- refers to the metropolitan area Bryan-College Station.
} 
The supply curves are presented in both graphical and tabular form. The tables explain the data or assumptions contained in the "steps" of the supply curves. For example, the first entry in Table 1-5 for 1-Sacramento describes 8,000 tons/year of wood waste that are landfilled along with MSW via the Placer County Materials Recovery Facility (Placer MRF); the tipping fee is $\$ 68 /$ ton. The last entry in that table describes 35,000 tons/year of wood waste that are given away by woodworking companies as animal bedding or firewood; the price is $\$ 0 /$ ton.

\section{Supply Curve Anatomy}

Four distinct categories of urban wood waste, two or more of which are present in every metropolitan area studied, combine to create the "anatomy" of an urban wood waste supply curve. In ascending order of price (\$/ton), these categories are:

- Wood disposed of in landfills or municipal solid waste $-\$ 85$ to $-\$ 16$ incinerators

- Wood delivered to (or picked up by) processors (private $-\$ 42$ to $-\$ 5$ or public) for recycling

- Wood privately dumped or burned, or informally $-\$ 5$ to $\$ 0$ recycled as mulch or firewood

- Wood processed by its generators and sold as products $\$ 3$ to $\$ 12$ (mulch, biofuel, pulp chips, furnish)

Table 15 shows the percentages of urban wood waste that fall into these four categories, as well as the populations and the per capita wood waste resources, in the 30 metropolitan areas. Figures 3 through 16 compare and contrast the supply curves in the different cities, by showing the four highest-ranked cities in each category on the left-hand side of the page (column 1), and the four lowest-ranked cities in each category on the right-hand side of the page (column 2). Figure 3 shows the supply curves for the four cities with the largest populations, and Figure 4 shows the supply curves for the four cities with the smallest populations. Interestingly, various shapes are seen in both groups of supply curves. The percentage of wood landfilled ranges from $25 \%$ to $55 \%$ in the four largest cities, and from $6 \%$ to $54 \%$ in the four smallest cities. The percentage of wood processed ranges from $0 \%$ to $72 \%$ in the four largest cities, and from $0 \%$ to $1 \%$ in the four smallest cities. The percentage of wood privately dumped or recycled ranges from $8 \%$ to $75 \%$ in the four largest cities, and from $25 \%$ to $57 \%$ in the four smallest cities. The percentage of wood sold by waste generators is $0 \%$ in the four largest cities and three of the four smallest cities, but is $67 \%$ in 17-Danville. Apparently, the population of a metropolitan area, in and of itself, does not have much influence on the shape of a wood waste supply curve.

\section{Wood Waste per Capita}

Figure 5 shows the supply curves for the four cities with the most wood waste per capita, and Figure 6 shows the supply curves for the four cities with the least wood waste per capita. Here, some differences that may be significant are seen in the shapes of supply curves in one group versus the other. The percentage of wood landfilled ranges from $6 \%$ to $22 \%$ in the four cities with the most wood waste, and from $25 \%$ to $71 \%$ in the four cities with the least wood waste. The percentage of wood processed exceeds $28 \%$ in three of the four cities with the most wood waste, and is $0 \%$ in three of the four cities with the least wood waste. The percentage of wood privately dumped or recycled ranges from $25 \%$ to $33 \%$ in the four cities with the most wood waste, and from $29 \%$ to $75 \%$ in the four cities with the least wood waste. The percentage of wood sold by waste generators is $25 \%$ and 
Table 15

Supply Curve Anatomy - Data for 30 Metropolitan Areas

\begin{tabular}{|c|c|c|c|c|c|c|c|c|c|}
\hline No. & Metro Area & State & Population & Total & TF & $\%$ Lfl & $\%$ Prc & $\%$ PD & $\%$ Sld \\
\hline 1 & Sacramento & $\overline{\mathrm{CA}}$ & $1,481,102$ & 0.300 & $\$ \$ 68$ & 20 & 72 & 8 & 0 \\
\hline 2 & Olympia & WA & 161,238 & 0.505 & $\$ 78$ & 12 & 32 & 56 & 0 \\
\hline 3 & Provo- & UT & 263,590 & 0.330 & $\$ 29$ & 25 & 40 & 34 & 0 \\
\hline 4 & Denver- & $\mathrm{CO}$ & $1,848,319$ & 0.313 & $\$ 22$ & 55 & 21 & 24 & 0 \\
\hline 5 & Lincoln & $\mathrm{NE}$ & 213,641 & 0.438 & $\$ 16$ & 54 & 0 & 46 & 0 \\
\hline 6 & Bismarck & ND & 83,831 & 0.235 & $\$ 30$ & 71 & 0 & 29 & 0 \\
\hline 7 & Bloomington- & IL & 129,180 & 0.379 & $\$ 28$ & 11 & 41 & 48 & 0 \\
\hline 8 & Battle Creek & MI & 135,982 & 0.308 & $\$ 42$ & 17 & 38 & 45 & 0 \\
\hline 9 & Mansfield & $\mathrm{OH}$ & 126,137 & 0.291 & $\$ 23$ & 27 & 24 & 48 & 0 \\
\hline 10 & Elmira & NY & 95,195 & 0.269 & $\$ 55$ & 43 & 0 & 57 & 0 \\
\hline 11 & Boston & MA & $1,950,855$ & 0.330 & $\$ 85$ & 28 & 54 & 18 & 0 \\
\hline 12 & Harrisburg & $\mathrm{PA}$ & 587,986 & 0.245 & $\$ 64$ & 30 & 12 & 58 & 0 \\
\hline 13 & Altoona & $\mathrm{PA}$ & 130,542 & 0.430 & $\$ 40$ & 14 & 0 & 52 & 34 \\
\hline 14 & Hagerstown & $\mathrm{MD}$ & 121,393 & 0.358 & $\$ 35$ & 21 & 2 & 76 & 0 \\
\hline 15 & Washington & DC & $3,923,574$ & 0.156 & $\$ 44$ & 25 & 0 & 75 & 0 \\
\hline 16 & Richmond- & VA & 865,640 & 0.829 & $\$ 50$ & 15 & 28 & 32 & 25 \\
\hline 17 & Danville & VA & 108,711 & 0.727 & $\$ 38$ & 6 & 1 & 25 & 67 \\
\hline 18 & Fayetteville & $\mathrm{NC}$ & 274,566 & 0.322 & $\$ 38$ & 31 & 0 & 69 & 0 \\
\hline 19 & Florence & $\mathrm{SC}$ & 114,344 & 0.273 & $\$ 30$ & 54 & 0 & 46 & 0 \\
\hline 20 & Greenville- & $\mathrm{SC}$ & 640,861 & 0.443 & $\$ 38$ & 20 & 0 & 75 & 5 \\
\hline 21 & Lexington- & KY & 348,428 & 0.278 & $\$ 25$ & 31 & 0 & 69 & 0 \\
\hline 22 & Memphis & $\mathrm{TN}$ & 981,747 & 0.378 & $\$ 28$ & 32 & 0 & 67 & 1 \\
\hline 23 & Decatur & $\mathrm{AL}$ & 131,556 & 0.426 & $\$ 25$ & 25 & 0 & 52 & 23 \\
\hline 24 & Macon- & GA & 281,103 & 0.347 & $\$ 28$ & 40 & 0 & 53 & 7 \\
\hline 25 & Lakeland- & $\mathrm{FL}$ & 405,382 & 0.523 & $\$ 44$ & 16 & 51 & 33 & 0 \\
\hline 26 & Bradenton & FL & 211,707 & 0.654 & $\$ 23$ & 22 & 50 & 27 & 0 \\
\hline 27 & Baton Rouge & LA & 528,264 & 0.490 & $\$ 28$ & 18 & 17 & 65 & 0 \\
\hline 28 & Shreveport & LA & 334,341 & 0.325 & $\$ 27$ & 22 & 0 & 75 & 3 \\
\hline 29 & Beaumont- & $\mathrm{TX}$ & 361,226 & 0.340 & $\$ 21$ & 16 & 50 & 32 & 2 \\
\hline 30 & Bryan- & $\mathrm{TX}$ & 121,862 & 0.281 & $\$ 24$ & 38 & 17 & 45 & 0 \\
\hline
\end{tabular}

Legend: Total $=$ total urban wood waste resource, tons/year/person

$\mathrm{TF}=$ highest tipping fee in metro area, $\$$ ton

$\% \mathrm{Lfl}=\%$ of wood waste landfilled

$\% \operatorname{Prc}=\%$ of wood waste processed

$\% \mathrm{PD}=\%$ of wood waste privately dumped or recycled

$\%$ Sld $=\%$ of wood waste sold by waste generators

$67 \%$ in the two cities with the most wood waste, and $0 \%$ in the other six cities in Figures 5 and 6. It appears that a large per capita wood waste resource in an area corresponds with high diversion rates from landfills and from private dumping, and high rates of commercial processing and sales of recycled wood products. Conversely, it appears that a small per capita wood waste resource in an area corresponds with high rates of landfilling and private dumping of wood, and with little or no wood processing. 


\section{Landfill Tipping Fees}

In every metropolitan area, the wood at the bottom of the supply curve is being landfilled (or incinerated, if the area has solid waste incineration facilities). Landfill tipping fees always represent the lowest (most negative) prices for wood waste in an area. It would be reasonable to expect that areas with the highest tipping fees would tend to have the greatest incentives for diverting wood from landfills into recycling and energy facilities. Figure 7 shows the supply curves for the four cities with the highest landfill tipping fees, and Figure 8 shows the supply curves for the four cities with the lowest landfill tipping fees. In the four cities with the highest tipping fees, the portion of the total wood waste stream being processed into fuel and other products ranges from about $12 \%$ to $72 \%$. In the four metropolitan areas with very low tipping fees, the portion of the total wood waste stream being processed into fuel and other products ranges from $21 \%$ to $50 \%$. The hypothesis that high tipping fees should lead to more wood waste diversion and processing is not well supported by the data gathered from these 30 metropolitan areas.

Figures 9 and 10 compare the four cities with the highest and lowest percentages of wood waste landfilled. The four cities with low percentages of wood landfilled are all relatively small cities with relatively large resources of urban wood waste. The majority of the wood waste in these cities is being privately dumped and/or sold by waste generators. Two of these cities (7-Bloomington- and 2-Olympia) have significant amounts of wood waste being processed. Three of the four cities with high percentages of wood landfilled have no wood being processed into products or sold by generators; essentially all of the wood wastes in these cities (6-Bismarck, 19-Florence, and 5-Lincoln) ends up in landfills or being privately dumped. It is difficult to find any pattern in Figures 7 through 10 that explains why some cities send greater percentages of wood wastes to landfills than others.

\section{Wood Processors}

In many metropolitan areas, the next set of steps on the supply curve above the "landfill steps" represent wood processors. These companies charge tipping fees somewhat lower than the landfills in the area in order to attract wood wastes. Some cities (e.g., 26Bradenton and 29-Beaumont-) pay wood processors to grind wood wastes diverted from city landfills. In most metropolitan areas, wood processing is a private sector operation. Some of the larger wood processing companies (e.g., in 1-Sacramento and 11-Boston) have a large number of individually negotiated tipping fees. In Figure 11, this shows up in the first three supply curves as a series of steps ranging from just above the landfill tipping fees to just below $\$ 0 /$ ton. (See the respective supply curve tables for these cities in Section D.) The supply curve for 26-Bradenton looks like a case of $100 \%$ landfilling and private dumping, but in fact the city pays a wood processor to grind wood and sell products, and charges the same tipping fee for incoming wood as for garbage. This is not evident from the graph, but is evident from Table 26-4 in Section D. The amount of wood being processed in the four cities in Figure 11 is very significant, ranging from $50 \%$ to $72 \%$ of the total resource. In every case, a large portion of the processed wood is going as fuel into biomass power plants.

Figure 12 has a somewhat misleading title (cities with the lowest percentage of wood processed), in that 13 of the 30 cities actually have $0 \%$ of their wood being processed, and Figure 12 shows just four of those. Looking at the 13 cities with no wood processing (see Table 15), there is no obvious pattern. The group includes the largest and smallest cities in the study, as well as cities with relatively high and low wood waste resources and tipping fees. It may be that the presence or absence of wood processing companies in a metropolitan area depends on factors such as public policy and entrepreneurial activity, and not on variables such as tipping fees, wood waste resources, or population. 


\section{Private Dumping or Recycling}

The next step in a wood waste supply curve is the "zero price line." In every metropolitan area studied, some wood (the majority of wood in some cases) is informally recycled, dumped, or burned by its generators. The most ubiquitous form of this behavior is the conversion of tree trimming wastes into mulch and firewood; wherever possible, tree service companies all over the country leave as much of this material with the land owners as they can. Comparing Figures 13 and 14, some cities have very long "zero price lines," and others have relatively short ones. The long ones, in Figure 13, represent about 75$76 \%$ of urban wood wastes being privately dumped. In the cities in Figure 14, the amount being privately dumped ranges from $8 \%$ to $25 \%$. Two of those cities (1-Sacramento and 11-Boston) have very high rates of wood processing as discussed above. Another city in the low private dumping group (4-Denver) has very low tipping fees and also a significant wood processing sector, so most of its wood waste is landfilled or processed.

\section{Wood Sold by Waste Generators}

In some of the metropolitan areas studied, large lumber mills or other wood products companies produce significant quantities of sawdust and shavings. Some of these areas also have large consumers of wood wastes (usually pulp and paper mills or power plants). In these cases, the lumber mills sell fuel and pulp chips to the paper mills and fuel to the power plants, and a series of "above zero" steps appear on the supply curve (see Figure 15). This wood is clearly a portion of the resource that has found a productive use. It is a byproduct rather than a waste. In one metropolitan area (17-Danville), wood byproducts from local lumber mills represent about $67 \%$ of the total wood waste resource. In the three other cities shown in Figure 15, wood sold by waste generators represents $23 \%$ to $34 \%$ of the total wood waste resources. In 21 of the 30 cities studied (four of which are shown in Figure 16), no wood is being sold by waste generators, and the highest step on those 21 supply curves is the "zero price line."

\section{National Supply Curve}

As discussed in Section A, the sample of 30 metropolitan areas studied was randomly selected and is representative of the total population of 281 metropolitan areas in the United States. As discussed in Section B, statistical analysis of the data shows that the total urban wood waste resource in any area of the United States can be reasonably well predicted as 0.333 tons/year/person, regardless of the size of the area considered. Finally, as discussed above, supply curves for the 30 metropolitan areas have common anatomical features and do not exhibit any noticeable patterns as a function of variables such as population, total wood resource, or landfill tipping fees. Therefore, with some confidence we have created a national urban wood waste supply curve as follows:

1. The data from the 30 supply curves were combined together to create a supply curve for the total sample of 30 cities. This sample has a population (1990) of 16,962,303 and a total urban wood waste resource of 5,656,710 tons/year (0.333 tons/year/person).

2. The wood waste quantities were multiplied by 11.38 , which is the ratio of the 1990 population of all 281 metropolitan areas in the US $(193,007,670)$ to the population of the 30 metropolitan areas studied $(16,962,303)$.

3. The resulting supply curve was plotted as shown in Figure 17. Note that this supply curve represents the metropolitan areas of the US only, and does not include areas outside the 281 metropolitan areas defined by the Census Bureau in 1990. The total estimated urban wood waste resource in the US is $64,373,000$ tons/year. 

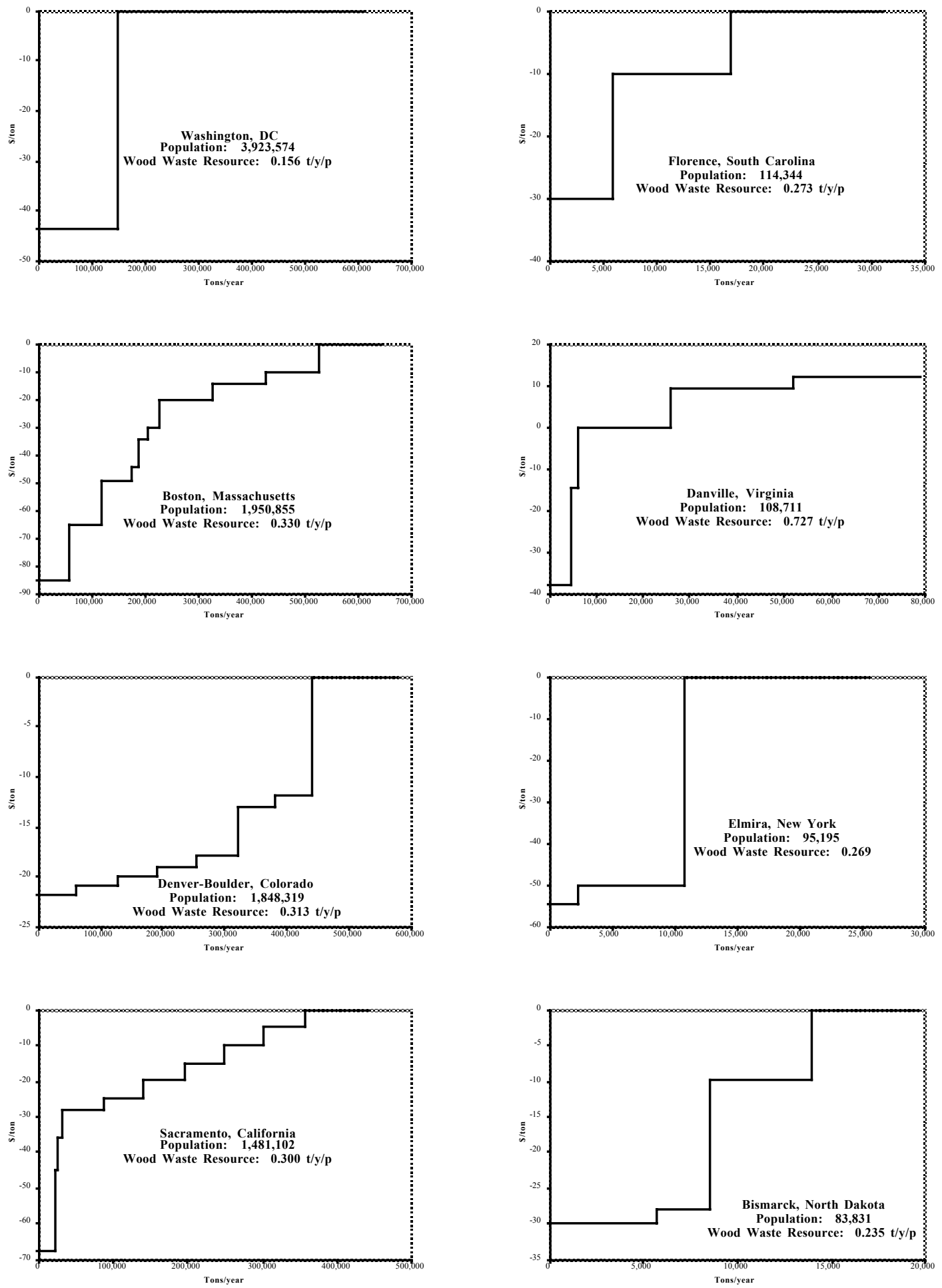

Figure 3 (Column 1). Cities with the Largest Populations.

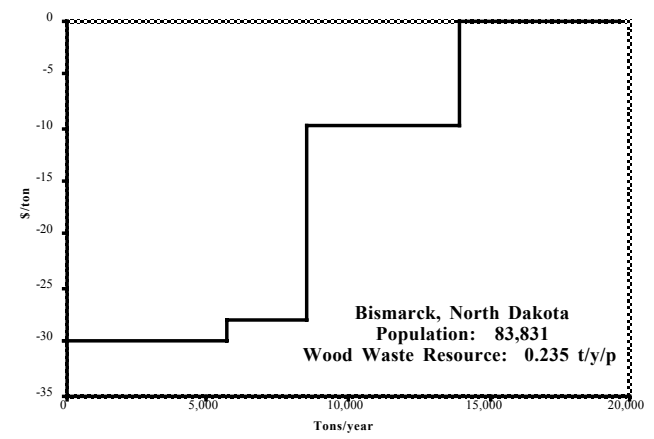

Figure 4 (Column 2). Cities with the Smallest Populations. 

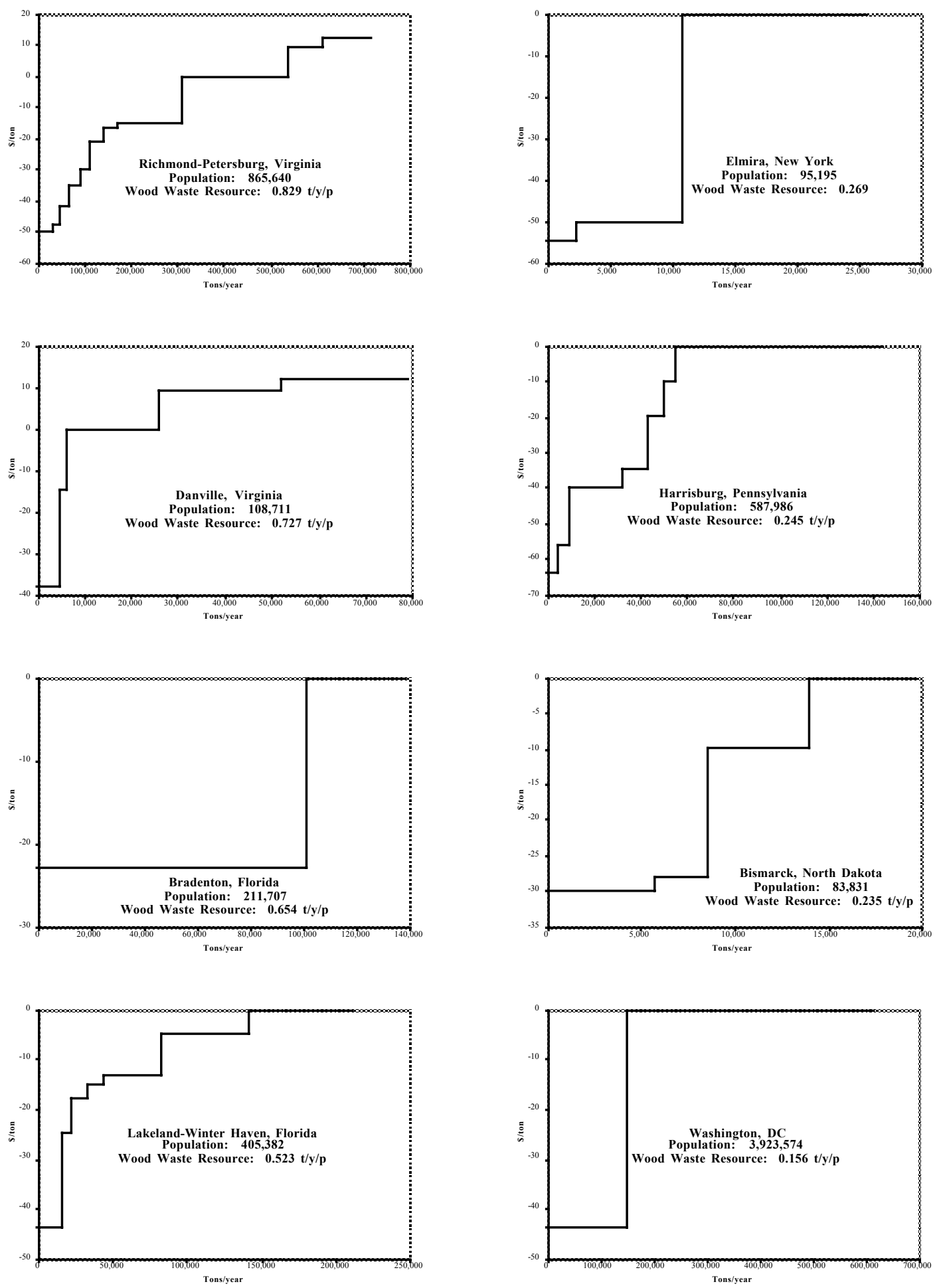

Figure 5 (Column 1). Cities with the Most Wood Waste Per Capita.

Figure 6 (Column 2). Cities with the Least Wood Waste Per Capita. 

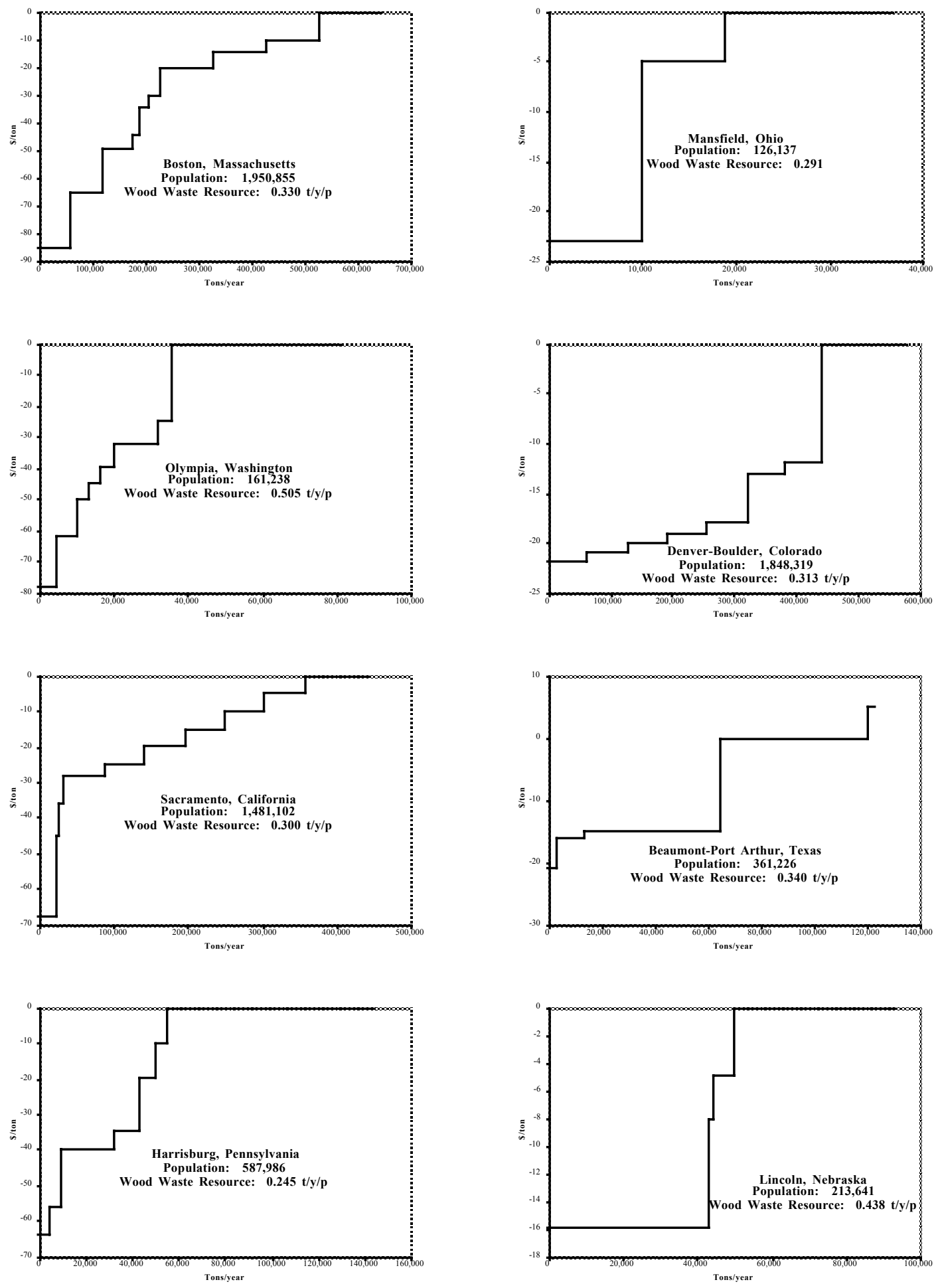

Figure 7 (Column 1). Cities with the Highest Landfill Tipping Fees.

Figure 8 (Column 2). Cities with the Lowest Landfill Tipping Fees. 

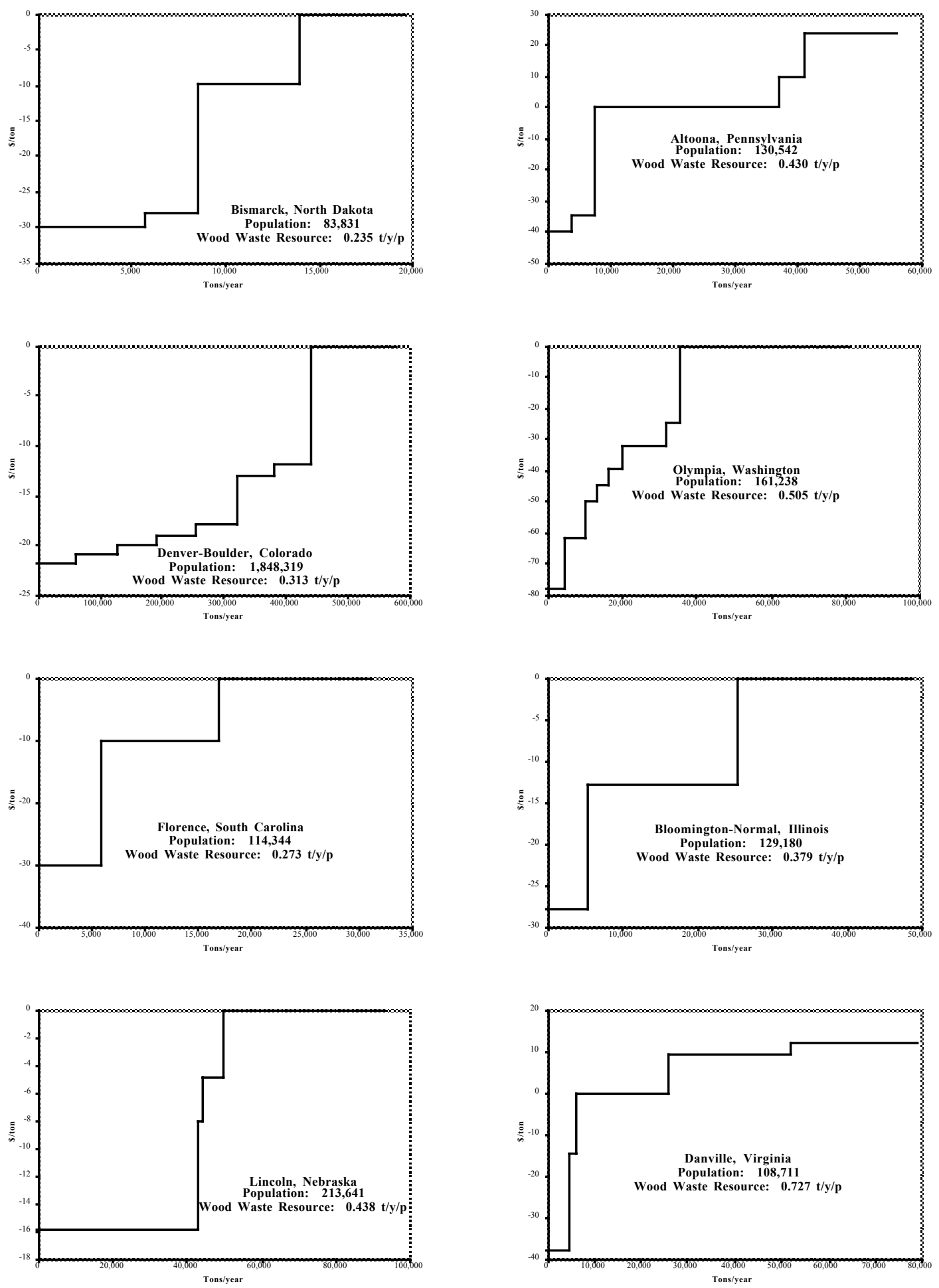

Figure 9 (Column 1). Cities with the Highest Percentage of Wood Landfilled.

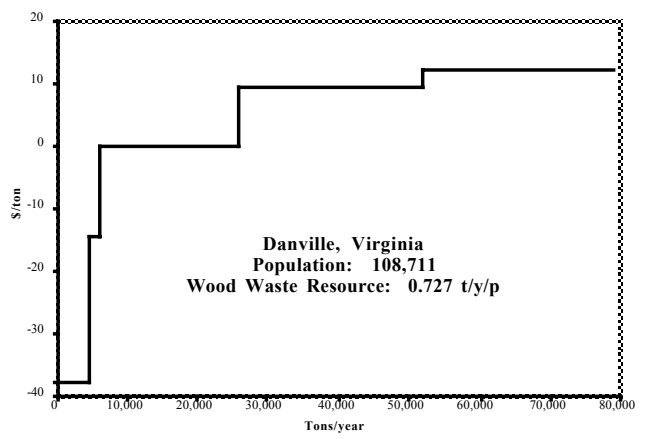

Figure 10 (Column 2). Cities with the Lowest Percentage of Wood Landfilled. 

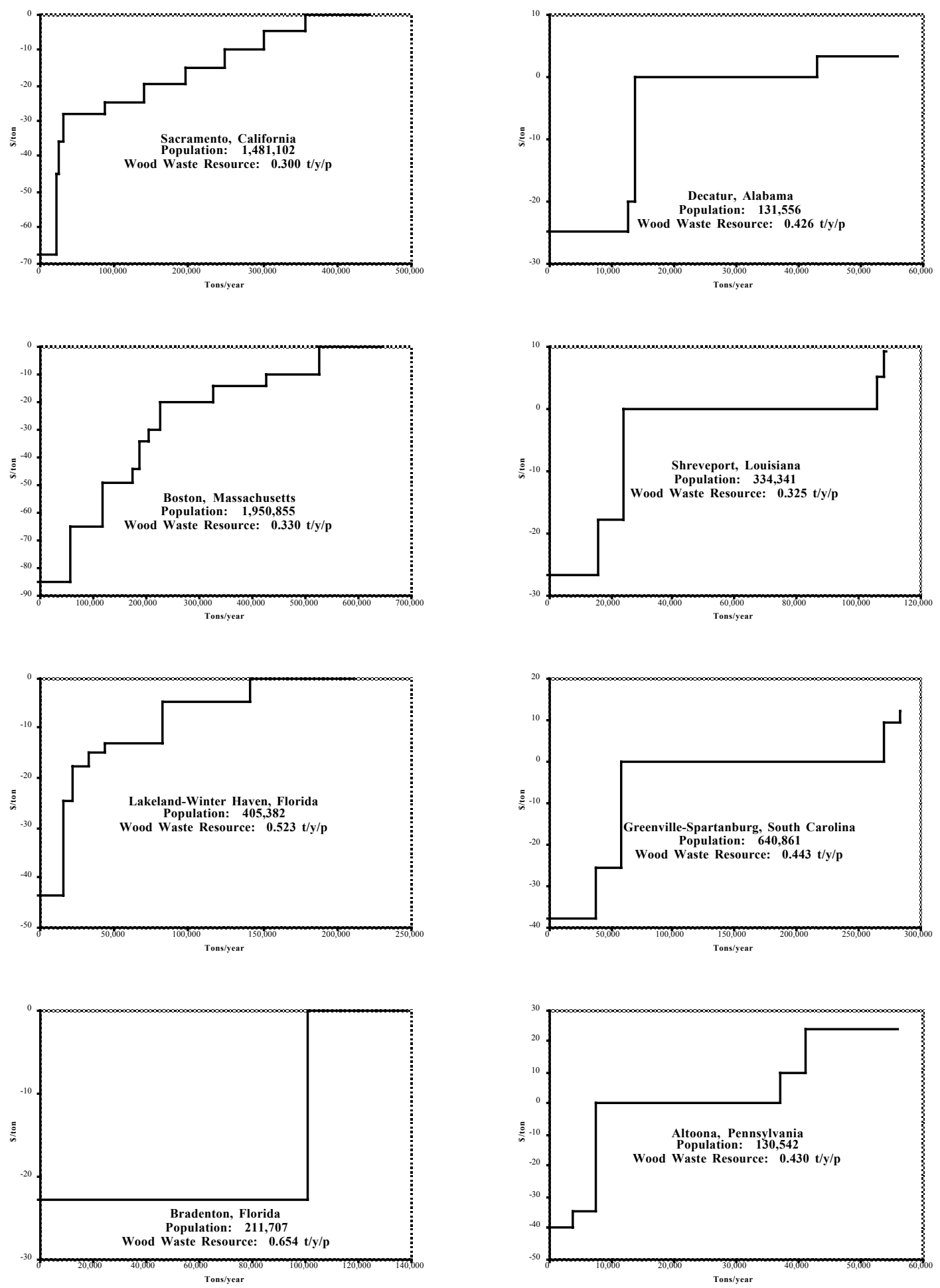

Figure 11 (Column 1). Cities with the Highest Percentage of Wood Processed.

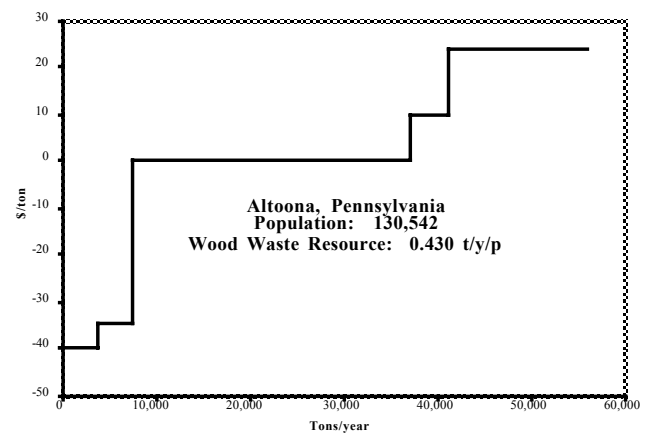

Figure 12 (Column 2). Cities with the Lowest Percentage of Wood Processed. 

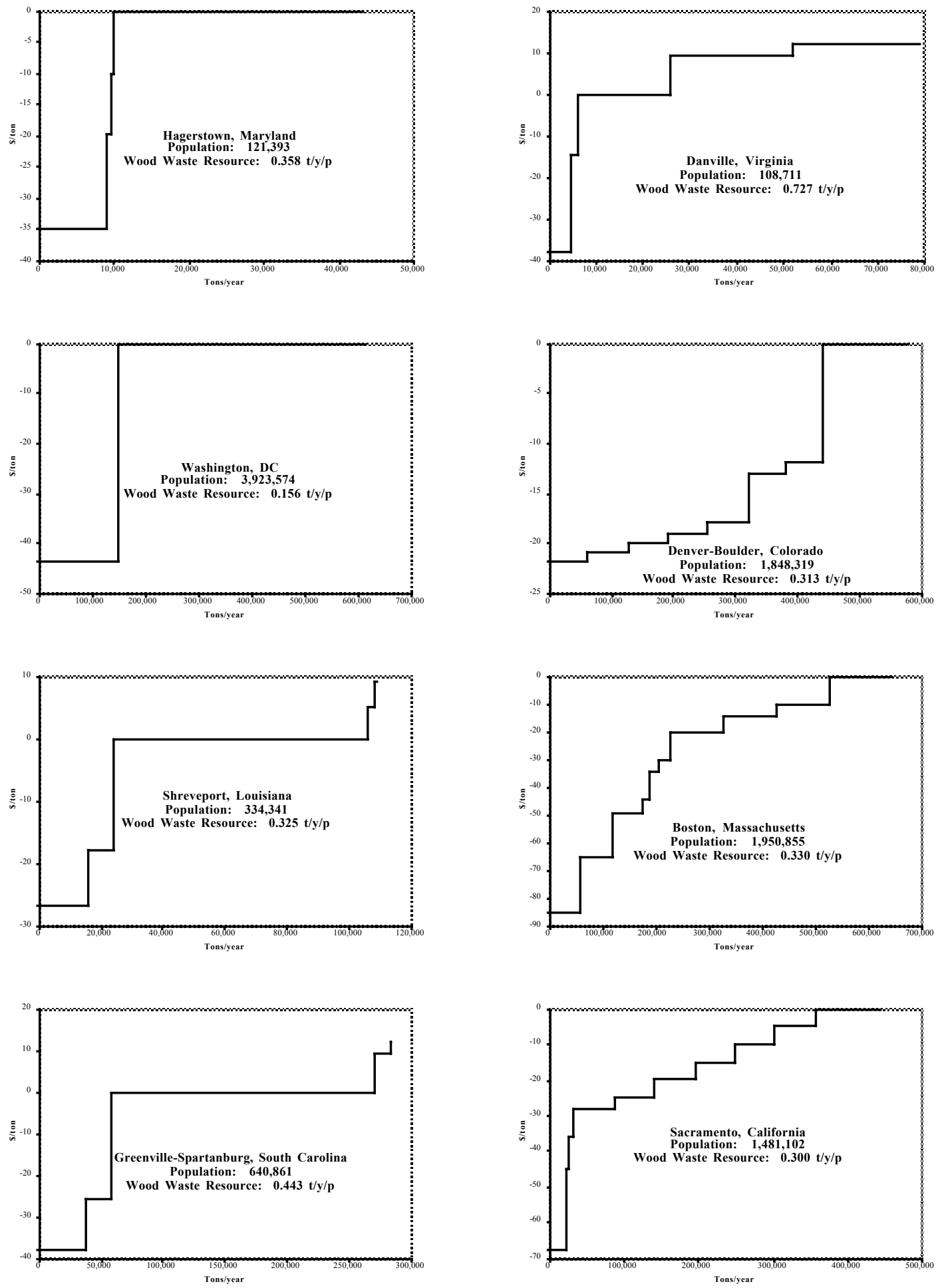

Figure 13 (Column 1). Cities with the Highest Percentage of Wood Privately Dumped or Recycled.

Figure 14 (Column 2). Cities with the Lowest Percentage of Wood Privately Dumped or Recycled. 

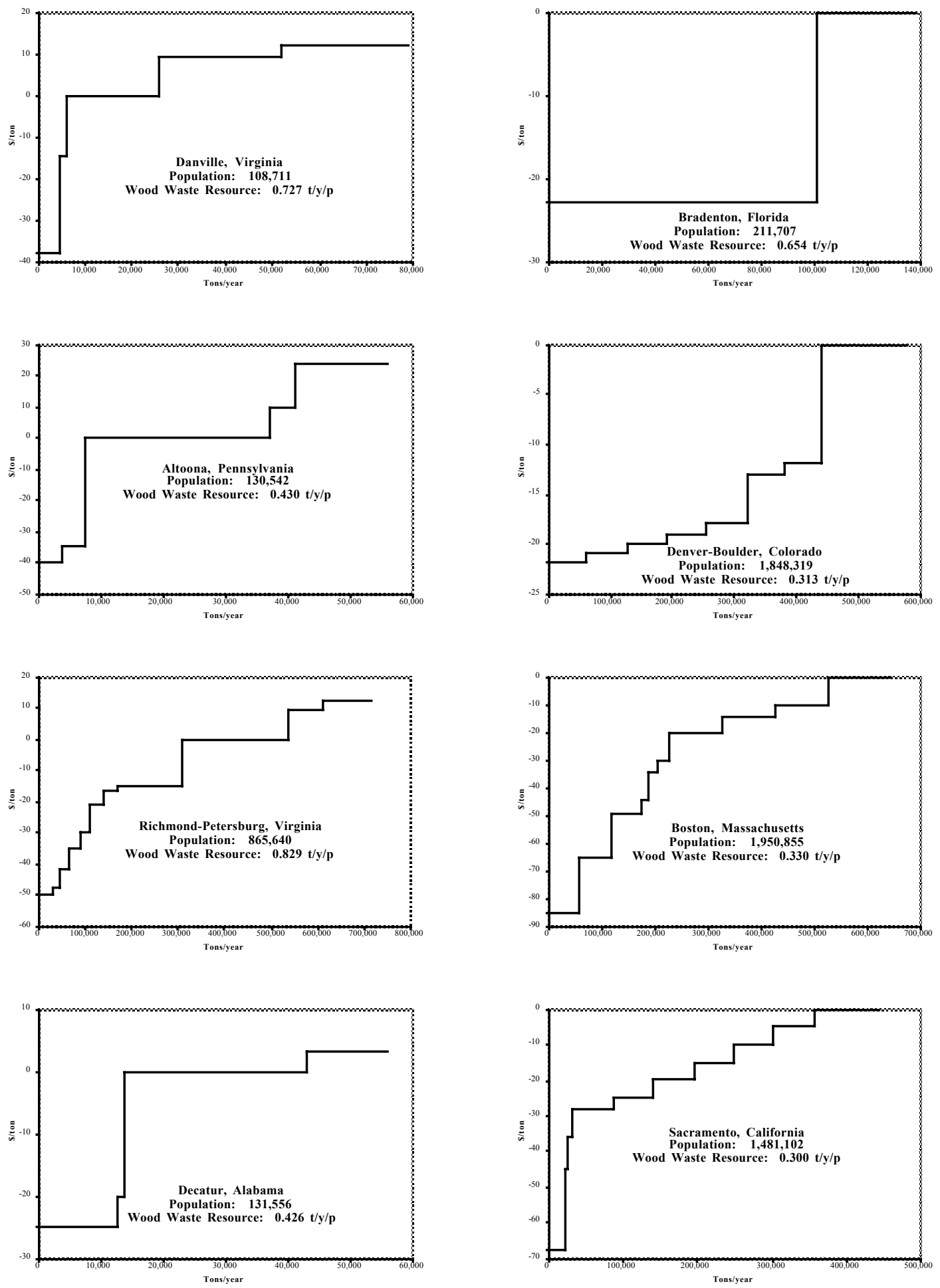

Figure 15 (Column 1). Cities with the Highest Percentage of Wood Sold by Waste Generators.

Figure 16 (Column 2). Cities with the Lowest Percentage of Wood Sold by Waste Generators. 


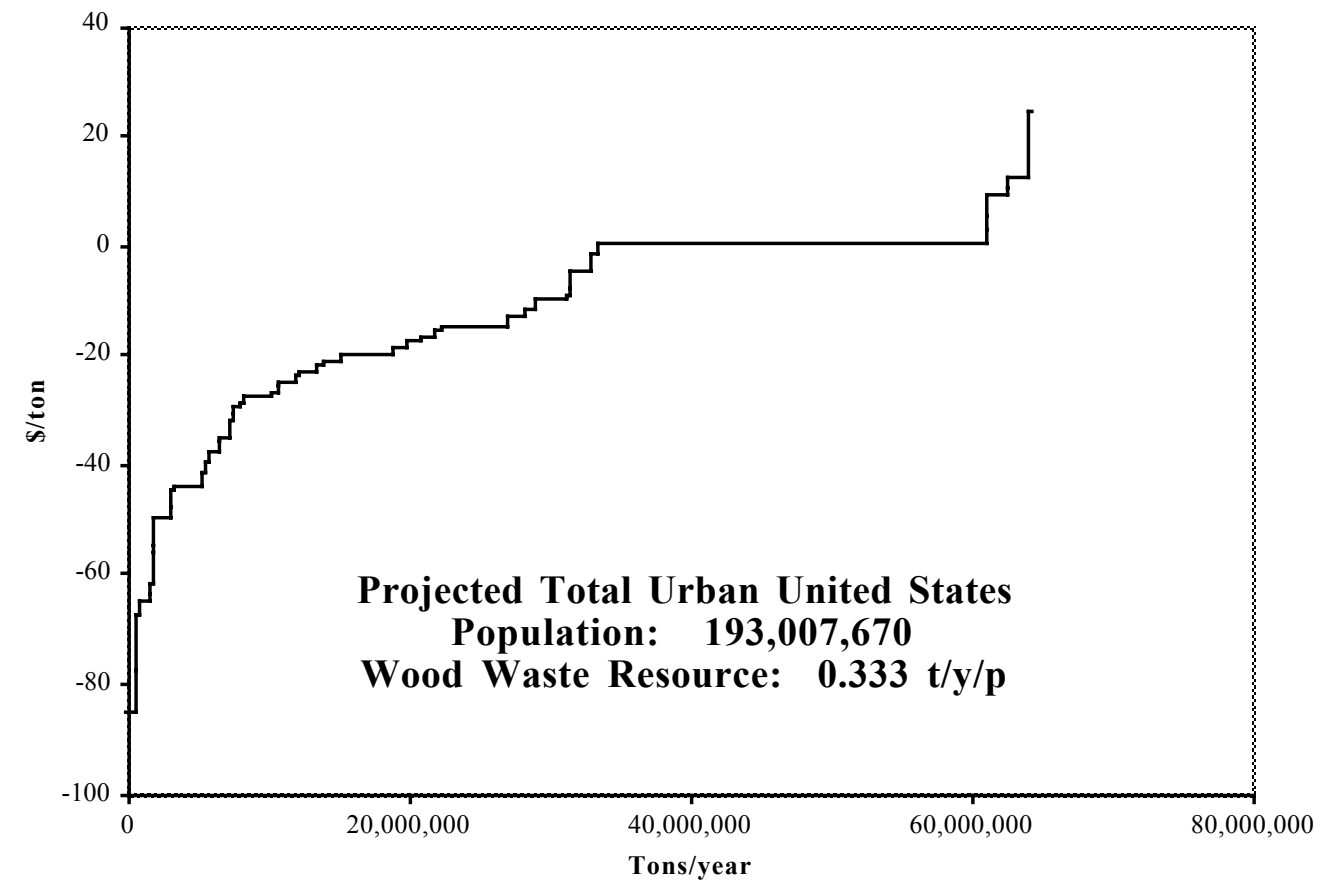

Figure 17. Supply Curve Projected for All Metropolitan Areas in the United States

The "steps" in the national supply curve appear much smaller than those in the individual cities because the spectrum of tipping fees is much wider. If we assume that the four parts of the national supply curve anatomy are represented by the price ranges below, the approximate percentages of the total urban wood waste resource are as follows:

Wood landfilled

Wood processed

Wood privately dumped

Wood sold by waste generators

$\begin{array}{cr}\text { - \$85 through - \$20/ton } & 30 \% \\ -\$ 19 \text { through - \$2/ton } & 22 \% \\ \text { \$0/ton } & 43 \% \\ \text { \$3 through \$24/ton } & 5 \% \\ & 100 \%\end{array}$




\section{METROPOLITAN AREA REPORTS}

1. Sacramento, California

Population (1990): 1,481,102

Sacramento, the capital of California, is in Sacramento County. West Sacramento, Davis, and several smaller communities are in Yolo County. Roseville, Rocklin, and Auburn are rapidly growing cities in Placer County. The area's private sector economy has been growing rapidly. State legislation has established recycling and waste reduction goals, and California has been a leader in promoting renewable energy. About $800 \mathrm{MW}$ of biomass power plants have been built, many within 100 miles of Sacramento. Although some of these operations have been curtailed recently, there is still a large flow of urban wood wastes from the Sacramento metropolitan area to several nearby biomass power plants.

Table 1-1 summarizes the data collected on urban wood resources in the Sacramento area The estimated total urban wood waste resource in Sacramento, 0.300 tons/year/person, is below the weighted average of 0.333 tons/year/person for the 30 metropolitan areas surveyed; the range for the 30 cities is from 0.156 to 0.829 tons/year/person. Tipping fees and solid waste regulations encourage recycling of wood wastes, and wood processing companies are supplying large customers with biomass fuel and furnish. The 92,000 tons/year going to biomass fuel are enough to generate about $8 \mathrm{MW}$ of electricity. Still, a large proportion of Sacramento's wood waste is informally recycled to mulch or disposed of in landfills. A biomass power project could probably secure 150,000-200,000 tons/year of feedstock at close to zero delivered cost, and produce 10-20 MW of electricity.

Table 1-1

Resource Estimate for Urban Wood Waste in Sacramento, California

Tons/Year

\begin{tabular}{|c|c|c|c|c|c|}
\hline Use or Disposal Method: & $\begin{array}{l}\text { MSW } \\
\text { Wood }\end{array}$ & $\begin{array}{c}\text { Industr. } \\
\text { Wood }\end{array}$ & $\begin{array}{c}\text { C/D } \\
\text { Wood }\end{array}$ & Total & $\begin{array}{c}\text { Price, } \\
\text { \$/ton }\end{array}$ \\
\hline Animal bedding & & 3,200 & & 3,200 & 0 \\
\hline Firewood & 31,000 & 800 & & 31,800 & 0 \\
\hline Mulch & 153,000 & 1,000 & 10,000 & 164,000 & 0 to -25 \\
\hline Biomass fuel & 87,000 & & 5,000 & 92,000 & 0 to -25 \\
\hline Furnish for fiberboard & 24,000 & 41,000 & & 65,000 & 0 to -25 \\
\hline Landfill & 33,000 & & 56,000 & 89,000 & -28 to -68 \\
\hline Total & 328,000 & 46,000 & 71,000 & 445,000 & \\
\hline Total, tons/year/person & 0.221 & 0.031 & 0.048 & 0.300 & \\
\hline
\end{tabular}

\section{Municipal Solid Waste (MSW) Collection and Disposal}

The area's solid waste stream is about $1,400,000$ tons/year, about $20 \%$ of which is $\mathrm{C} / \mathrm{D}$ debris. Sacramento County's landfills received 1,093,000 tons in 1996. The two transfer stations and the landfill diverted about 12,000 tons of wood and yard wastes in 1996. 
Tipping fees are \$28.05/ton at the Sacramento County Landfill and \$44.80/ton at the transfer stations. The county recycling manager stated that after significant educational efforts, about $20 \%$ of area residents compost their yard wastes and tree trimmings.

West Sacramento and Davis send their solid waste (less than 100,000 tons/year) to Yolo County Central Landfill. The tipping fee is $\$ 36 /$ ton. A wood and green waste recycling center at the landfill charges a tipping fee of \$23.50/ton. The Western Placer Waste Management Authority operates a Materials Recovery Facility (MRF) and landfill near Rocklin. Total solid waste to the MRF was 184,000 tons in 1996. This "dirty MRF" sells a full range of recycled products, including wood products such as colored wood chips (about 2,000 tons/year). Tipping fees at the MRF are \$68/ton of garbage, \$45/ton of green waste, and $\$ 10 /$ ton of clean inert material. My estimates of the amounts of wood waste entering landfills along with the solid waste in the Sacramento area are approximately:

MSW wood: $3 \%$ of $1,100,000=33,000$ tons/year;

C/D wood: $20 \%$ of $280,000=56,000$ tons/year.

Waste Management, Inc. (WMI) owns a large wood processing operation, summarized in Table 1-2. Furnish (clean, under 1/4-inch wood chips sold to medium density fiberboard plants) is probably the highest-value large-volume product sold by this facility. These figures include the wood processed at the Yolo County Landfill. Tipping fees charged by WMI range from zero to about $\$ 25 /$ ton, and are individually negotiated for larger accounts. At the Yolo County Landfill wood receiving yard, the tipping fees are \$23.50/ton, or $\$ 10$ /pickup. Wood wastes accepted there are wood, pallets, and tree and brush prunings.

Table 1-2

Wood Wastes Processed by Waste Management, Inc. Tons/Year

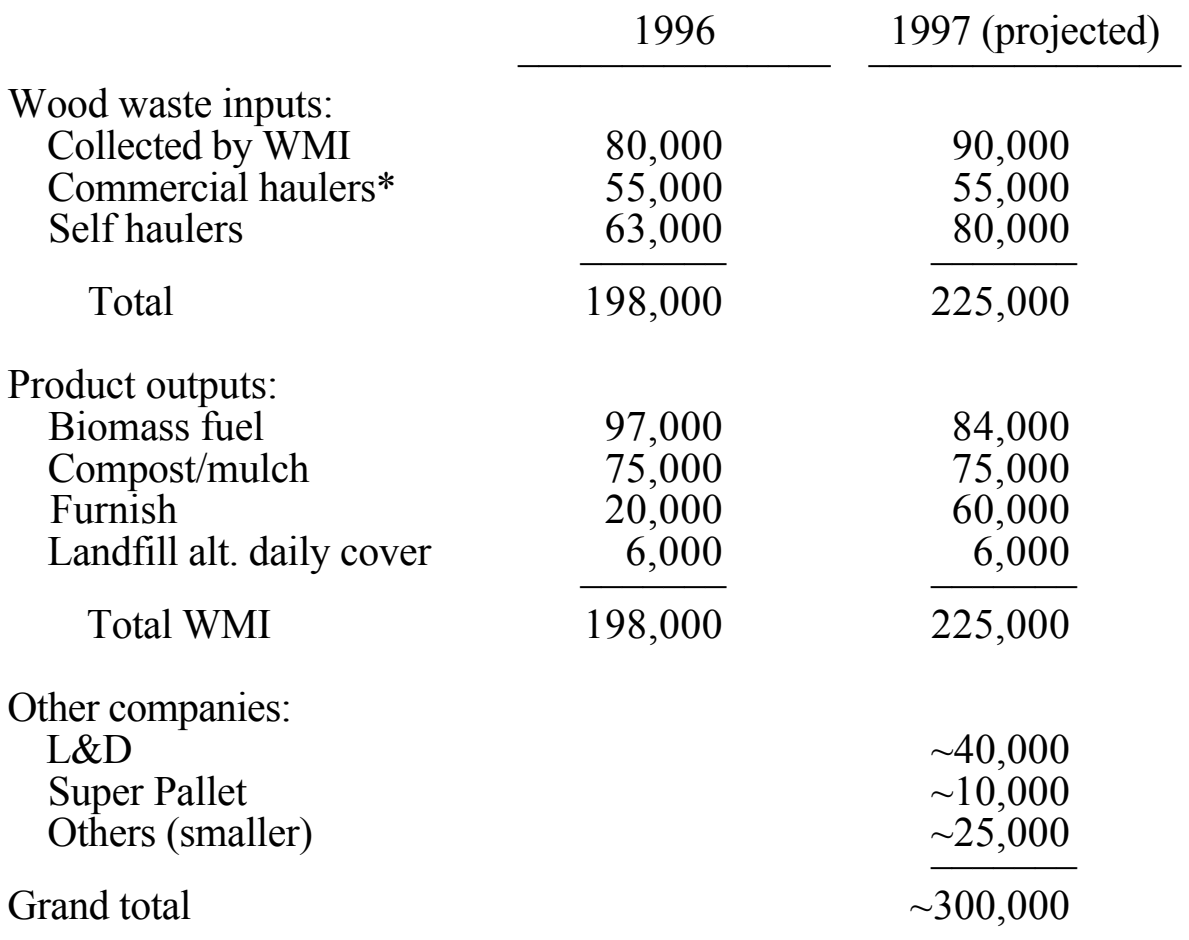

*Commercial haulers include the city and county. 


\section{MSW Wood (Primarily Tree and Yard Wastes)}

The City of Sacramento collects about 80,000 tons/year of yard wastes. The production of compost at the city facility is limited to $12,000-15,000$ tons/year by site constraints. The difference $(68,000$ tons/year) presumably goes to commercial wood recyclers such as WMI. Sacramento accounts for about $1 / 4$ of the metro area's total population, but the other cities and unincorporated areas are less aggressive in their yard waste programs, so I estimate that they collect a total of about 91,000 tons/year of wood and yard wastes.

Sacramento Municipal Utility District's tree trimming work generates about 40,000 tons/year (about 30,000 tons/year of mulch and 10,000 tons/year of firewood). The City of Sacramento Parks \& Recreation Department produces about 750 tons/year of mulch and 250 tons/year of firewood. I estimate the Parks \& Recreation total wood waste generation rate for the metro area to be 3,000 tons/year of mulch, and 1,000 tons/year of firewood.

The Sacramento Yellow Pages list 69 tree service companies. The 12 companies I talked to leave firewood and mulch onsite for the owners whenever that is acceptable. A small amount goes to the compost center at the county landfill or to the WMI wood processing yard (and is already counted as part of the estimates above). About 80 crews are active in tree trimming and removal work, generating about 20,000 tons/year of firewood and 60,000 tons/year of mulch.

Table 1-3 summarizes the estimated resources of MSW wood in the Sacramento area. The total estimate, 328,000 tons/year (of which about 33,000 tons/year enter landfills), is equivalent to 0.221 tons/year/person based on the Sacramento metropolitan area population of $1,481,102$. This is slightly above the weighted average of 0.209 tons/year/person of MSW wood for the 30 metropolitan areas surveyed; the range is from 0.134 to 0.538 tons/year/person.

\section{Table 1-3}

\section{Resource Estimate for MSW Wood in Sacramento, California} Tons/year

\begin{tabular}{|c|c|c|c|c|c|}
\hline & Mulch & $\begin{array}{l}\text { Furnish } \\
\text { \& Fuel* }\end{array}$ & $\begin{array}{l}\text { Fire- } \\
\text { wood }\end{array}$ & $\begin{array}{c}\text { Land- } \\
\text { fill }\end{array}$ & Total \\
\hline Hauled with trash & & & & 33,000 & $\begin{array}{r}33,000 \\
175,000\end{array}$ \\
\hline Municipal yard waste recycl. & 63,000 & 111,000 & 1,000 & & $\begin{array}{r}175,000 \\
40000\end{array}$ \\
\hline $\begin{array}{l}\text { Utility tree trimming } \\
\text { Private tree service co's }\end{array}$ & $\begin{array}{l}30,000 \\
60,000\end{array}$ & & $\begin{array}{l}10,000 \\
20,000\end{array}$ & & $\begin{array}{l}40,000 \\
80,000\end{array}$ \\
\hline Total & 153,000 & 111,000 & 31,000 & 33,000 & 328,000 \\
\hline
\end{tabular}

\section{Industrial Wood Wastes}

The Sacramento Yellow Pages list 20 companies under Pallets and Skids; two companies under Trusses-Construction; 16 companies under Lumber-Wholesale; 30 companies under Lumber-Retail; and 79 companies under Cabinet Makers, Furniture Designers \& Custom Builders, and Furniture Manufacturers (woodworking companies). About $80 \%$ of the pallet companies have their waste wood picked up by Waste Management, Inc. I estimate that about 20,000 tons/year of pallet waste wood are picked up by WMI, and that about 5,000 tons/year are recycled by other companies (primarily Super Pallet). Also about 80\% 
of the lumber companies I talked to have their waste wood picked up by Waste Management, Inc. I estimate that about 16,000 tons/year of lumber company waste wood are picked up by WMI, and that about 1,000 tons/year of waste wood (primarily sawdust) are recycled by some of the lumber companies directly, into uses such as animal bedding.

Truss companies tend to grind their own wood wastes. I estimate that the two truss companies generate about 2,000 tons/year of mulch or animal bedding. None of the hardwood companies do any significant amount of milling in the Sacramento metro area. They produce an insignificant amount of urban wood waste. Woodworking companies generate about 1,200 tons/year of animal bedding and 800 tons/year of firewood.

Table 1-4 summarizes the estimated resources of industrial wood wastes in the Sacramento metropolitan area. The total estimate of 46,000 tons/year is equivalent to 0.031 tons/year/person based on the Sacramento metropolitan area population of $1,481,102$. This is below the weighted average of 0.048 tons/year/person of industrial wood waste for the 30 metropolitan areas surveyed; the range is from 0.001 to 0.488 tons/year/person.

\section{Table 1-4 \\ Resource Estimate for Industrial Wood Wastes in Sacramento, California Tons/year}

\begin{tabular}{|c|c|c|c|c|c|}
\hline & Furnish & $\begin{array}{l}\text { Animal } \\
\text { Bedding }\end{array}$ & Mulch & $\begin{array}{l}\text { Fire- } \\
\text { wood }\end{array}$ & Total \\
\hline Pallet companies & 25,000 & & & & 25,000 \\
\hline Truss companies & & 1,300 & 700 & & 2,000 \\
\hline Whlsl lumber co's & 16,000 & & & & 16,000 \\
\hline Retail lumber co's & & 700 & 300 & & 1,000 \\
\hline Woodworking co's & & 1,200 & & 800 & 2,000 \\
\hline Total & 41,000 & 3,200 & 1,000 & 800 & 46,000 \\
\hline
\end{tabular}

\section{Construction/Demolition Wood Wastes}

The Sacramento Yellow Pages list 30 companies under Demolition Contractors and seven companies under Land Clearing \& Leveling Companies. I was able to talk to ten and three of these companies, respectively, who said they take most of their C/D wastes, containing unknown quantities of wood mixed with dirt, concrete, etc., to the landfill. On some occasions they are able to separate wood, and generally take those separated wood wastes to the WMI facility.

Based on the information I received, I estimate the $\mathrm{C} / \mathrm{D}$ wood waste resource to consist of the following: 15,000 tons/year of separated wood wastes to WMI (of which I assigned 10,000 to mulch and 5,000 to biomass fuel); and 56,000 tons of wood contained in the mixed material taken to the landfill. The estimated 71,000 tons/year total is equivalent to 0.048 tons/year/person based on the Sacramento metropolitan area population of $1,481,102$. This is below the weighted average of 0.076 tons/year/person of $\mathrm{C} / \mathrm{D}$ wood for the 30 metropolitan areas surveyed; the range is from 0.015 to 0.250 tons/year/person. 


\section{Supply Curve}

Figure 1-1 shows the supply curve for urban wood wastes in the Sacramento area. Table 1-5 shows the data and assumptions used to produce the supply curve.

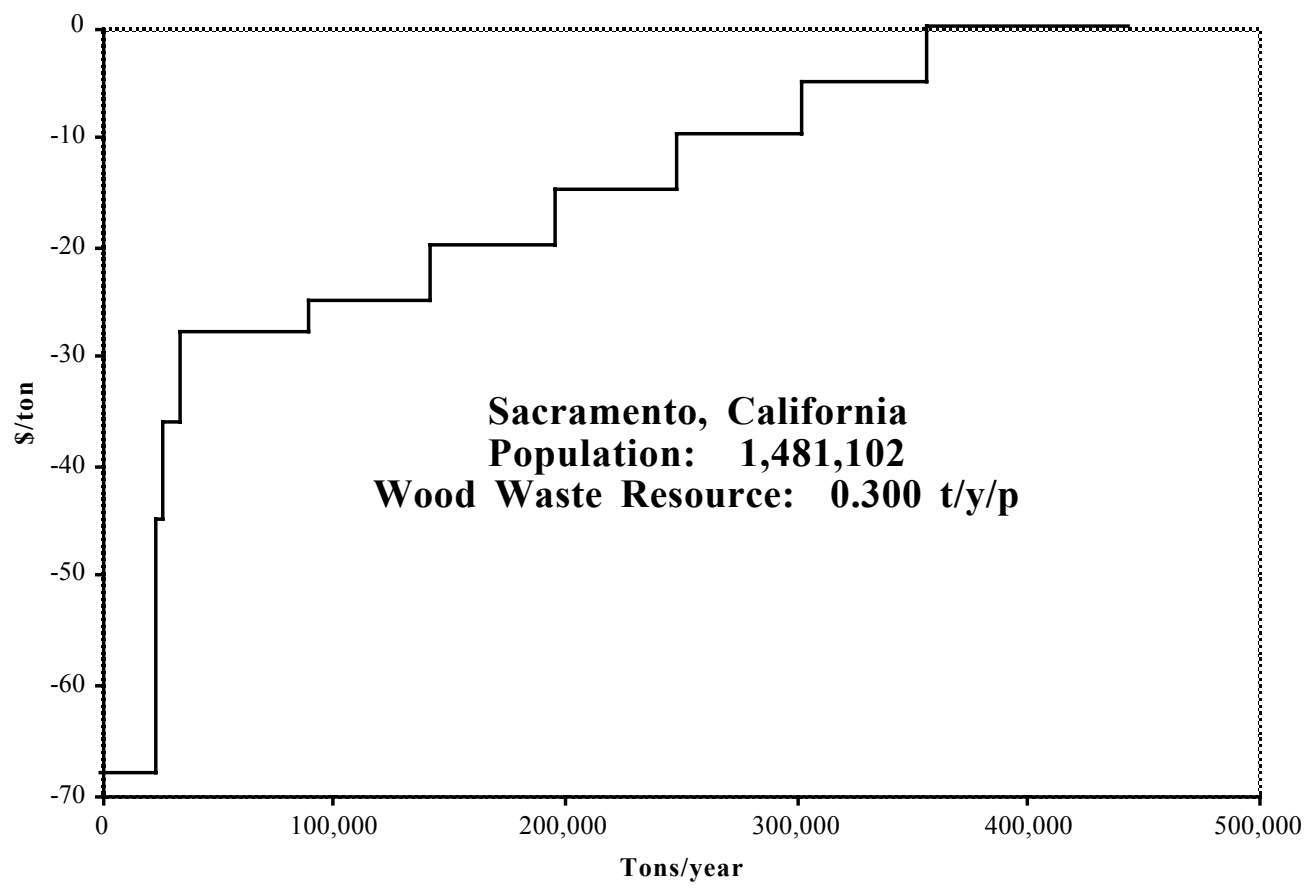

Figure 1-1. Supply Curve for Urban Wood Wastes in Sacramento, California

Table 1-5

Data and Assumptions Used in Supply Curve for Sacramento

$\underline{\text { Tons/year }}$ Cumulative $\$$ \$/ton

8,000

15,000

4,000

2,000

4,000

19,000

37,000

53,000

54,000

53,000

54,000

53,000

54,000

35,000

8,000

23,000

27,000

29,000

33,000

52,000

89,000

142,000

196,000

249,000

303,000

356,000

410,000

445,000
Assumptions/Comments

-68 Landfilled with MSW - Placer MRF

-68 Landfilled with C/D - Placer MRF

-45 Landfilled with MSW - Sacramento transfer stations

-36 Landfilled with MSW - Yolo landfill

-36 Landfilled with C/D - Yolo landfill

-28 Landfilled with MSW - Sacramento landfill

-28 Landfilled with C/D - Sacramento landfill

-25 Wood processors - tree wastes, industrial wood

-20 Wood processors - tree wastes, industrial wood

-15 Wood processors - tree wastes, industrial wood

-10 Wood processors - tree wastes, industrial wood

-5 Wood processors - tree wastes, industrial wood

0 Wood processors - tree wastes, industrial wood

0 Animal bedding, firewood - given away 
Olympia -- the capital of Washington, located south of Tacoma in Thurston County -- is characterized by very high landfill tipping fees $(\$ 60-70 /$ ton $)$ and a relatively stagnant economy. The wet climate supports some of the highest natural yields of wood per acre in the US. The existence of a huge forest products industry in the region means that wood waste handling in the Puget Sound area is relatively efficient and competent.

Thurston County is a mix of rural communities, medium-size cities, college campuses and retirement villages. Employment in government agencies comprises $40 \%$ of all jobs in the county, and $50 \%$ of all wages. Nearly $25 \%$ of the county's workforce commutes north of the county for employment. Manufacturing accounts for only $4.5 \%$ of available jobs, while the average for the rest of the state is $15 \%$. Pabst (a beer company) is the only manufacturer in the top 10 employers in the county.

Table 2-1 summarizes the data collected on urban wood resources in the Olympia area. The estimated total urban wood waste resource in Olympia, 0.505 tons/year/person, is above the weighted average of 0.333 tons/year/person for the 30 metropolitan areas surveyed; the range for the 30 cities is from 0.156 to 0.829 tons/year/person. Markets exist in the region for biomass fuel and for feedstock (furnish) to conversion plants such as medium density fiberboard, pulp mills, etc. However, significant amounts of wood wastes are informally recycled to mulch or allowed to enter the landfill. A biomass project developer could probably secure 40,000-50,000 tons/year of feedstock at close to zero delivered cost, and produce 3-5 MW of electricity.

Table 2-1

Resource Estimate for Urban Wood Waste in Olympia, Washington

\begin{tabular}{|c|c|c|c|c|c|}
\hline \multirow[b]{2}{*}{ Use or Disposal Method: } & \multicolumn{4}{|c|}{ Tons/Year } & \multirow[b]{2}{*}{$\begin{array}{c}\text { Price, } \\
\text { \$/ton }\end{array}$} \\
\hline & $\begin{array}{l}\text { MSW } \\
\text { Wood }\end{array}$ & $\begin{array}{c}\text { Industr. } \\
\text { Wood }\end{array}$ & $\begin{array}{c}\text { C/D } \\
\text { Wood }\end{array}$ & Total & \\
\hline Firewood & 9,000 & 200 & & 9,200 & 0 \\
\hline Mulch and compost & 52,000 & & & 52,000 & 0 to -32 \\
\hline Animal bedding & & 1,200 & & 1,200 & 0 to -50 \\
\hline Biofuel & & 5,000 & & 5,000 & -40 to -50 \\
\hline Furnish & & 4,000 & & 4,000 & -40 to -50 \\
\hline Landfill & 5,000 & & 5,000 & 10,000 & -62 to -78 \\
\hline Total & 66,000 & 10,400 & 5,000 & 81,400 & \\
\hline Total, tons/year/person & 0.409 & 0.065 & 0.031 & 0.505 & \\
\hline
\end{tabular}

\section{Municipal Solid Waste (MSW) Collection and Disposal}

The Olympia metropolitan area (population 161,238) and Thurston County $(192,000)$ can be considered nearly equivalent for purposes of collecting data on MSW and wood wastes. The Thurston County Hawks Prairie Landfill receives all the trash from Olympia, Lacey, Tumwater, and unincorporated areas of Thurston County. The total disposal rate is about 130,000 tons/year (0.8 tons/year/person), growing at about $2 \% /$ year. C/D debris accounts for about $20 \%$ of the total solid waste, or about 26,000 tons/year. The landfill tipping fees are $\$ 62.10 /$ ton (plus tax) for regular garbage, $\$ 77.60 /$ ton for C/D debris, and $\$ 69.85 /$ ton for roofing and specially handled wastes such as railroad ties. The county also operates three small transfer stations in Rainier, Rochester, and Summit Lake that charge fees of 
$\$ 10.25 /$ cubic yard of regular garbage (and yard wastes), $\$ 29.20 /$ cubic yard of C/D debris, and $\$ 19.75$ for roofing and other special wastes.

The largest private trash hauling company operating in the area is Le May Inc. Subsidiary Pacific Disposal picks up trash in Lacey, Tumwater, and unincorporated Thurston County. The company also rents out drop boxes to lumber companies, pallet companies, etc., and hauls the waste wood to large wood recycling yards (mostly in the Tacoma area). They do not keep track of the quantities of wood. My estimate based on the information I received is 10,000 tons/year (counted as industrial wood, below).

Based on the information above, my estimates of the amounts of wood waste entering landfills along with the solid waste in the Olympia metropolitan area are approximately:

MSW wood: $5 \%$ of $104,000=5,000$ tons/year;

C/D wood: $20 \%$ of $26,000=5,000$ tons/year.

\section{MSW Wood (Primarily Tree and Yard Wastes)}

As discussed above, an estimated 5,000 tons/year of MSW wood enter the county landfill along with the solid waste. The landfill operates a compost center for yard wastes and small tree trimmings. The tipping fee is $\$ 32.00 /$ ton, about half the amount for regular garbage. The current compost production rate is about 12,000 tons/year. Accepted materials are grass clippings, leaves, branches, roots with no dirt, shrubs less than 4 inches in diameter and six feet tall, and untreated lumber. Nails, dirt, sod, and treated lumber are not accepted. Compost is available for sale seven days a week at $\$ 5.40 /$ half cubic yard.

South Sound Soils in Tenino composts yard waste, for a tipping fee of about $\$ 25 /$ ton. My estimate of the quantity is about 2,000 tons/year. Rainier Wood Recyclers operates a small wood recycling yard next to the landfill, grinding stumps and other wood wastes for roughly the same tipping fees. My estimate of the quantity is about 1,000 tons/year.

Jones Quarry Inc. in Olympia charges a tipping fee of \$11/cubic yard (about \$36/ton) for wood wastes (untreated, unpainted, stumps, limbs, etc.). They sell and give away products such as mulch, animal bedding, and play yard material. Their total production in 1996 was about 2,300 tons/year.

The City of Olympia sponsors a neighborhood chipping program in which six or more neighbors pile their wood wastes, the city grinds the wood, and the residents keep the chips. There were 24 sessions in 1996, and 36 sessions in the first nine months of 1997. My estimate of the total amount of wood waste recycled in this program is 1,000 tons/year.

The Olympia Yellow Pages lists 38 tree service companies. I was able to talk to seven of these companies, all of whom said that they leave firewood and mulch onsite for the owners whenever that is acceptable. A small amount goes to the compost center at the county landfill (and is already counted as part of the 12,000 ton/year estimate above). I estimate that about 40 crews are active in tree trimming and removal work, generating about 8,000 tons/year of firewood and 32,000 tons/year of mulch.

Every few years, usually in the spring, a massive wet snowstorm creates large amounts of wood debris throughout the region. Typically the counties and cities end up giving away wood chips to large users such as the Tacoma Public Utilities Steam Plant No. 2, a 50 MW power plant that burns primarily wood and RDF. I have not included "storm event" wood in the resource estimate because its timing and amount are too unpredictable. 
The forester at Puget Sound Energy did not return my calls, so I have no information on the utility's tree trimming program. Because of the heavily wooded nature of the area, the amount of wood generated must be significant. My guesstimate is 5,000 tons/year, which I assume gets recycled into mulch and firewood.

Table 2-2 summarizes the estimated resources of MSW wood in Olympia, Washington. The total estimate, 66,000 tons/year (of which 5,000 tons/year enter the landfill), is equivalent to 0.409 tons/year/person based on the Olympia metropolitan area population of 161,238. This is well above the weighted average of 0.209 tons/year/person of MSW wood for the 30 metropolitan areas, which range from 0.134 to 0.538 tons/year/person.

Table 2-2

Resource Estimate for MSW Wood in Olympia, Washington

Tons/year

\begin{tabular}{|c|c|c|c|c|}
\hline & Mulch & $\begin{array}{l}\text { Fire- } \\
\text { wood }\end{array}$ & $\begin{array}{c}\text { Land- } \\
\text { fill }\end{array}$ & Total \\
\hline Hauled with trash & & & 5,000 & 5,000 \\
\hline Municipal yard waste recycl. & 16,000 & & & 16,000 \\
\hline Utility tree trimming & 4,000 & 1,000 & & 5,000 \\
\hline Private tree service co's & 32,000 & 8,000 & & 40,000 \\
\hline Total & 52,000 & 9,000 & 5,000 & 66,000 \\
\hline
\end{tabular}

\section{Industrial Wood Wastes}

The Olympia Yellow Pages list one company under Pallets and Skids; no local companies under Trusses-Construction or Lumber-Wholesale; 13 local companies under LumberRetail; and 20 companies under Cabinet Makers, Furniture Designers \& Custom Builders, and Furniture Manufacturers (woodworking companies).

There are two large wood processing and recycling operations in the Seattle-Tacoma metropolitan area. These companies attract some of the larger commercial waste wood streams from the Olympia area. Recovery One in Tacoma grinds tens of thousands of tons of wood per year and produces a full range of products, including fuel for wood-fired power plants, furnish for medium-density fiberboard plants, etc. Tipping fees for most types of wood are in the $\$ 40-50 /$ ton range, but go as high as $\$ 80 /$ ton for large stumps. Northwest Wood \& Fiber Recovery in Auburn (Northeast of Tacoma) has a similar facility that receives some wood wastes from the Olympia metropolitan area. As discussed above under MSW collection and disposal, my estimate of the wood wastes hauled to these recyclers is 10,000 tons/year. I estimate that 5,000 tons/year end up as biomass fuel, 4,000 tons/year as furnish, and 1,000 tons/year as animal bedding.

For example, REN Pallet Company in Lacey sends about 400 tons/year of scrap pallets from the Olympia area (primarily the brewery) to Northwest Wood \& Fiber Recovery in Auburn. The lumber companies I talked to generate another 600 tons/year or so, which they send to the wood processing companies in the Tacoma area.

I did not find any woodworking companies in the Olympia area that generate large quantities (i.e., truckloads per week) of sawdust or wood scraps. They produce very small amounts of wood scraps that are hauled to the landfill, used by family and friends, and/or given away as animal bedding or firewood. My estimate for the total amount of wood 
generated by these companies is 400 tons/year -- 200 tons/year of animal bedding and 200 tons/year of firewood.

Table 2-3 summarizes the estimated resources of industrial wood wastes in the Olympia metropolitan area. The total estimate of 10,400 tons/year is equivalent to 0.065 tons/year/person based on the Olympia metropolitan area population of 161,238. This is above the weighted average of 0.048 tons/year/person of industrial wood waste for the 30 metropolitan areas surveyed; the range is from 0.001 to 0.488 tons/year/person.

Table 2-3

Resource Estimate for Industrial Wood Wastes in Olympia, Washington Tons/year

\begin{tabular}{|c|c|c|c|c|c|}
\hline & Biofuel & Furnish & $\begin{array}{l}\text { Animal } \\
\text { Beddin }\end{array}$ & $\begin{array}{l}\text { Fire- } \\
\text { wood }\end{array}$ & Total \\
\hline $\begin{array}{l}\text { Pallet companies + } \\
\text { Whlsl lumber co's + } \\
\text { Retail lumber co's } \\
\text { Woodworking co's }\end{array}$ & 5,000 & 4,000 & $\begin{array}{r}1,000 \\
200\end{array}$ & 200 & $\begin{array}{r}10,000 \\
400\end{array}$ \\
\hline Total & 5,000 & 4,000 & 1,200 & 200 & 10,400 \\
\hline
\end{tabular}

\section{Construction/Demolition Wood Wastes}

The manager at the county landfill estimates that C/D debris accounts for about $20 \%$ of the total material entering the landfill. In turn, I believe that on the order of $20 \%$ of that material is wood that could be separated, although not cheaply. This gives an estimate of perhaps 5,000 tons/year of C/D wood entering the landfill.

The Olympia Yellow Pages list 16 companies under Land Clearing \& Leveling Companies. I was able to talk to three of these companies, who said they take their C/D wastes to the landfill. The tipping fee is so high $(\$ 77.60 /$ ton) that it would not be difficult to believe that a fair amount of rural dumping takes place, but I did not receive any information to this effect. The estimated 5,000 tons/year total is equivalent to 0.031 tons/year/person based on the Olympia metropolitan area population of 161,238. This is below the weighted average of 0.076 tons/year/person of C/D wood for the 30 metropolitan areas surveyed; the range is from 0.015 to 0.250 tons/year/person. 


\section{Supply Curve}

Figure 2-1 shows the supply curve for urban wood wastes in the Olympia area. Table 2-4 shows the data and assumptions used to produce the supply curve.

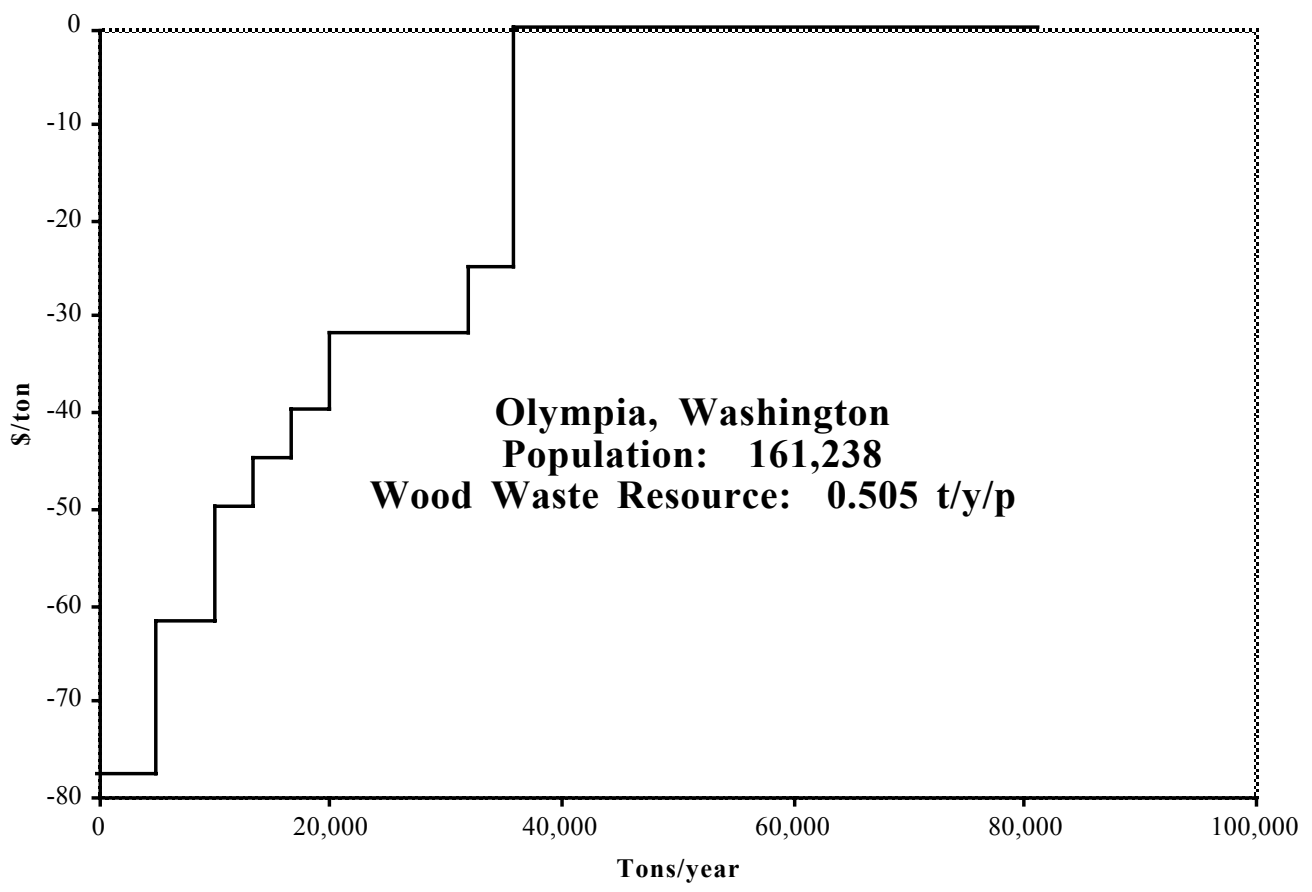

Figure 2-1. Supply Curve for Urban Wood Wastes in Olympia, Washington

Table 2-4

Data and Assumptions Used in Supply Curve for Olympia

Tons/year Cumulative $\frac{\text { \$/ton }}{5,000}$

5,000

5,000

3,300

3,400

3,300

12,000

4,000

45,400

$5,000 \frac{\$ 1 / 0 n}{-78}$

$10,000 \quad-62$

$13,300 \quad-50$

$16,700 \quad-45$

20,000

32,000

36,000

81,400

\section{Assumptions/Comments}

Landfilled with C/D - Thurston County landfill

Landfilled with MSW - Thurston County landfill

Wood processors - tree wastes, industrial wood

Wood processors - tree wastes, industrial wood

-40 Wood processors - tree wastes, industrial wood

-32 County landfill wood recycling - compost

-25 Wood recyclers - compost

0 Firewood, mulch, animal bedding - given away 
The Provo-Orem metropolitan area consists of the two adjoining cities Provo and Orem, plus about 23 other small cities and towns that cluster along Interstate 15 for about ten miles to the north of Orem and south of Provo. All of these municipalities lie within Utah County. Salt Lake City is about 30 miles further north, in Salt Lake County. The metropolitan area is bordered on the east by the Wasatch mountain range, and on the west by Utah Lake. The economy is healthy, with software, computer, and telecommunications industries clustered in modern industrial park complexes. Brigham Young University is a major factor in the local economy and cultural life as well.

Table 3-1 summarizes the data collected on urban wood resources in the Provo-Orem area. The estimated total urban wood waste resource in Provo-Orem, 0.330 tons/year/person, is nearly equal to the weighted average of 0.333 tons/year/person for the 30 metropolitan areas surveyed; the range for the 30 cities is from 0.156 to 0.829 tons/year/person. A biomass power project could probably secure 50,000-60,000 tons/year of feedstock at close to zero delivered cost, and produce 3-6 MW of electricity.

Table 3-1

Resource Estimate for Urban Wood Waste in Provo-Orem, Utah

\begin{tabular}{|c|c|c|c|c|c|}
\hline \multirow[b]{2}{*}{ Use or Disposal Method: } & \multicolumn{4}{|c|}{ Tons/Year } & \multirow[b]{2}{*}{$\begin{array}{c}\text { Price, } \\
\text { \$/ton }\end{array}$} \\
\hline & $\begin{array}{l}\text { MSW } \\
\text { Wood }\end{array}$ & $\begin{array}{c}\text { Industr. } \\
\text { Wood }\end{array}$ & $\begin{array}{c}\text { C/D } \\
\text { Wood }\end{array}$ & Total & \\
\hline Animal bedding, etc. & & 1,200 & & 1,200 & 0 \\
\hline Firewood & 5,000 & 1,100 & & 6,100 & 0 \\
\hline Mulch and compost & 54,000 & 1,600 & 2,000 & 57,600 & 0 to -20 \\
\hline Landfill & 11,000 & & 11,000 & 22,000 & -27 to -29 \\
\hline Total & 70,000 & 3,900 & 13,000 & 86,900 & \\
\hline Total, tons/year/person & 0.266 & 0.015 & 0.049 & 0.330 & \\
\hline
\end{tabular}

\section{Municipal Solid Waste (MSW) Collection and Disposal}

With the exception of about 1,200 tons/year that enter the Payson City landfill, all of the MSW in the Provo-Orem metropolitan area is compacted at one of two transfer stations and hauled to remote desert landfills. The 1996 total MSW disposal figures were:

South Utah Valley transfer station (Provo and south)

North Utah County transfer station (Orem and north) Payson City landfill

\section{Total}

110,000 tons/year 153,641

$\frac{1,200}{264,841 \text { tons/year }}$

The 265,000 tons/year of solid waste, when divided by the metropolitan area population of 263,590 , are equivalent to 1.01 tons/year/person. My assumption is that about $20 \%$ of the total solid waste is $\mathrm{C} / \mathrm{D}$ debris. The City of Provo provides residential trash pickup service; Orem contracts this work out to Waste Management, Inc. Private haulers handle all of the commercial and industrial trash pickup in the metropolitan area. The largest private haulers in the area are Waste Management, Inc., BFI, and Burbridge. 
In Provo, yard waste is collected separately (no pallets or construction debris may be included in yard waste) and composted with biosolids at a facility near the sewage treatment plant and the old closed landfill; from sales figures I estimate that they currently produce about 1,100 tons/year of compost. MSW is hauled to the South Utah Valley Waste District transfer station in Springville, where metals, foam rubber, tires, and batteries are recycled. Everything else, including wood, is compacted and hauled by truck to the Bayview Landfill in the west Utah desert near Alberta. Tipping fees at the south county transfer station are $\$ 27 /$ ton for trash from within the district, and \$37/ton for trash from outside the district.

The North Utah County transfer station is owned and operated by a special district that consists of Orem and ten other cities and unincorporated areas north of Orem. Tipping fees are $\$ 28.50 /$ ton. Lower fees are charged for wood and yard waste brought to the north county transfer station. Tipping fees for wood and yard waste are $\$ 4$ for average pickup loads (vs. \$7.50), \$8 for large loads (vs. \$15), and \$19.50/ton for weighed (very large) loads (vs. \$28.50). Metals, foam rubber, tires, and batteries are separated on the tipping floor and recycled; the remaining MSW is compacted, dumped through the floor into railroad cars, and hauled to the East Carbon landfill in Utah's eastern desert.

This transfer station received over 200,000 tons of material in 1996, and sent 153,641 tons to the landfill. At least 20,000 tons was yard waste. The transfer station has a tub grinder that handles most types of wood. Large tree stumps are not ground; they are landfilled. Wood that has commercial value, such as dimensional lumber and plywood, is separated and sold. Mulch goes to two sewage treatment plants to be mixed and composted with their sewage sludge. The sewage plants' demand for wood mulch is decreasing because they now have trommel screens that allow them to reuse a large portion of the wood chips. Whatever mulch is not composted is spread on the closed landfill adjacent to the transfer station. It will take years to reach the desired depth of 3-4 feet over the closed landfill.

Based on the information above, my estimates of the amounts of wood waste entering landfills along with the solid waste in the Provo-Orem metropolitan area are approximately:

MSW wood: $5 \%$ of $212,000=11,000$ tons/year;

C/D wood: $20 \%$ of $53,000=11,000$ tons $/$ year.

\section{MSW Wood (Primarily Tree and Yard Wastes)}

The North Utah County transfer station diverts about 35,000 tons/year of wood and yard wastes. This includes industrial wood waste, C/D wood, and green waste. For simplicity, I have counted the full 35,000 ton/year estimate as MSW wood. None of the major trash haulers in the area (WMI, BFI, Laidlaw, and Burbridge) separate or process wood wastes.

Utah Power \& Light Company operates throughout the state, but many of the cities have their own municipal power agencies. Provo City Power generates about 300 tons/year of firewood and 1,000 tons/year of mulch from tree trimming. I estimate the total amount of wood generated by utility tree trimming operations in the Provo-Orem metropolitan area is 2,000 tons/year of firewood and 6,000 tons/year of mulch. Brigham Young University (BYU) grinds about 1,000 tons/year of tree trimmings to mulch and uses it on campus.

Several years ago a commercial wood grinding yard operated in the Provo-Orem area, but it went into bankruptcy in 1993 or 1994 . The north valley transfer station purchased the grinder and some other equipment. The problem was a lack of markets for ground wood wastes in the area. The grinding yard was charging tipping fees up to double those at the landfills at the time. The transfer station manager thinks tipping fees need to be in the $\$ 30$ $40 /$ ton range before commercial wood recycling can be profitable in the Provo-Orem area. 
I talked to five of the eight tree service companies listed in the Provo-Orem Yellow Pages, and obtained a resource estimate from only one of them. They generate about 200 tons/year of firewood, which they sell for about $\$ 100-150 /$ cord. Their mulch is all given away, and probably amounts to another 800 tons/year or so. I estimate that a total of about 10 tree service crews operate in the Provo-Orem metro area, generating 2,000 tons/year of firewood and 8,000 tons/year of mulch.

Table 3-2 summarizes the estimated resources of MSW wood in Provo-Orem, Utah. The total estimate, 70,000 tons/year (of which 11,000 tons/year enter landfills), is equivalent to 0.266 tons/year/person based on the Provo-Orem metropolitan area population of 263,590 . This is above the weighted average of 0.209 tons/year/person of MSW wood for the 30 metropolitan areas, which range from 0.134 to 0.538 tons/year/person.

\section{Table 3-2 \\ Resource Estimate for MSW Wood in Provo-Orem, Utah Tons/year}

\begin{tabular}{|c|c|c|c|c|}
\hline & Mulch & $\begin{array}{l}\text { Fire- } \\
\text { wood }\end{array}$ & $\begin{array}{l}\text { Land- } \\
\text { fill }\end{array}$ & Total \\
\hline Hauled with trash & & & 11,000 & 11,000 \\
\hline Municipal yard waste recycl. & 40,000 & 1,000 & & 41,000 \\
\hline Utility tree trimming & 6,000 & 2,000 & & 8,000 \\
\hline Private tree service co's & 8,000 & 2,000 & & 10,000 \\
\hline Total & 54,000 & 5,000 & 11,000 & 70,000 \\
\hline
\end{tabular}

\section{Industrial Wood Wastes}

The Provo-Orem Yellow Pages list five companies under Pallets and Skids; four companies under Trusses-Construction; two companies under Lumber-Wholesale; six companies under Lumber-Retail; and 28 companies under Cabinet Makers, Furniture Designers \& Custom Builders, and Furniture Manufacturers (woodworking companies). Two of the five pallet companies provided useful information. Another company, which has the largest market share of pallet services in the Provo-Orem metro area, operates out of Salt Lake City; its wastes are not part of the Provo-Orem wood waste resource. My total estimate for pallet wastes in the Provo-Orem metro area is about 1,000 tons/year, of which about 800 tons/year go to animal bedding and mulch, and 200 tons/year go to firewood.

Three of the four truss companies in the Provo-Orem area pay Contractors Waste Removal to haul off their waste wood. CWR processes some of the wood waste into pallets, animal bedding, fuel pellets, etc. The remainder becomes mulch, or is given away for firewood. Based on the sizes of the roll-off bins and frequency of pickup, I estimate about 2,000 tons/year for all of the truss companies together.

The wholesale lumber companies are very efficient at reusing nearly all of their wood, and generate a relatively tiny amount of waste, mostly sawdust. My total estimate for the lumber companies in the Provo-Orem metro area is about 200 tons/year of sawdust, which is given away as animal bedding.

I did not find any woodworking companies in the Provo-Orem area that generate large quantities (i.e., truckloads per week) of sawdust or wood scraps. They produce very small 
amounts of wood scraps that are hauled to the landfill, used by family and friends, and/or given away as animal bedding or firewood. My estimate for the total amount of wood generated by these companies is 500 tons/year -- 200 tons/year of animal bedding and 300 tons/year of firewood.

Table 3-3 summarizes the estimated resources of industrial wood wastes in Provo-Orem, Utah. The total estimate of 3,900 tons/year is equivalent to 0.015 tons/year/person based on the Provo-Orem metropolitan area population of 263,590. This is below the weighted average of 0.048 tons/year/person of industrial wood waste for the 30 metropolitan areas surveyed; the range is from 0.001 to 0.488 tons/year/person.

Table 3-3 Resource Estimate for Industrial Wood Wastes in Provo-Orem, Utah
Tons/year

\begin{tabular}{|c|c|c|c|c|}
\hline & Mulch & $\begin{array}{l}\text { Animal } \\
\text { Beddin }\end{array}$ & $\begin{array}{l}\text { Fire- } \\
\text { wood }\end{array}$ & Total \\
\hline Pallet companies & 400 & 400 & 200 & 1,000 \\
\hline Truss companies & 1,200 & 400 & 400 & 2,000 \\
\hline Whlsl lumber co's & & 200 & & 200 \\
\hline Retail lumber co's & & & 200 & 200 \\
\hline Woodworking co's & & 200 & 300 & 500 \\
\hline Total & 1,600 & 1,200 & 1,100 & 3,900 \\
\hline
\end{tabular}

\section{Construction/Demolition Wood Wastes}

The Provo-Orem Yellow Pages list three companies under Demolition Contractors and four companies under Land Clearing \& Leveling. I called all of these companies and was successful in getting through to one of the demolition contractors and three of the land clearing and leveling companies.

The Provo-Orem area is experiencing a high degree of residential and commercial development. Land clearing, especially in former orchards, generates large amounts of wood. Most of the C/D wood is landfilled; my estimate is 11,000 tons/year. Stumps are generally landfilled. Some property owners want the mulch produced from the wood on their sites, in which case the contractors leave it. More often, trees and tree fragments are hauled to the transfer stations, where they are recycled or landfilled as described above under MSW wood. My guesstimate of the amount of ground-up C/D wood left onsite for owners in the Provo-Orem metro area is 2,000 tons/year.

The estimate of 13,000 tons/year for C/D wood is equivalent to 0.049 tons/year/person based on the Provo-Orem metropolitan area population of 263,590. This is below the weighted average of 0.076 tons/year/person of $\mathrm{C} / \mathrm{D}$ wood for the 30 metropolitan areas surveyed; the range is from 0.015 to 0.250 tons/year/person. 


\section{Supply Curve}

Figure 3-1 shows the supply curve for urban wood wastes in the Provo-Orem area. Table 3-4 shows the data and assumptions used to produce the supply curve.

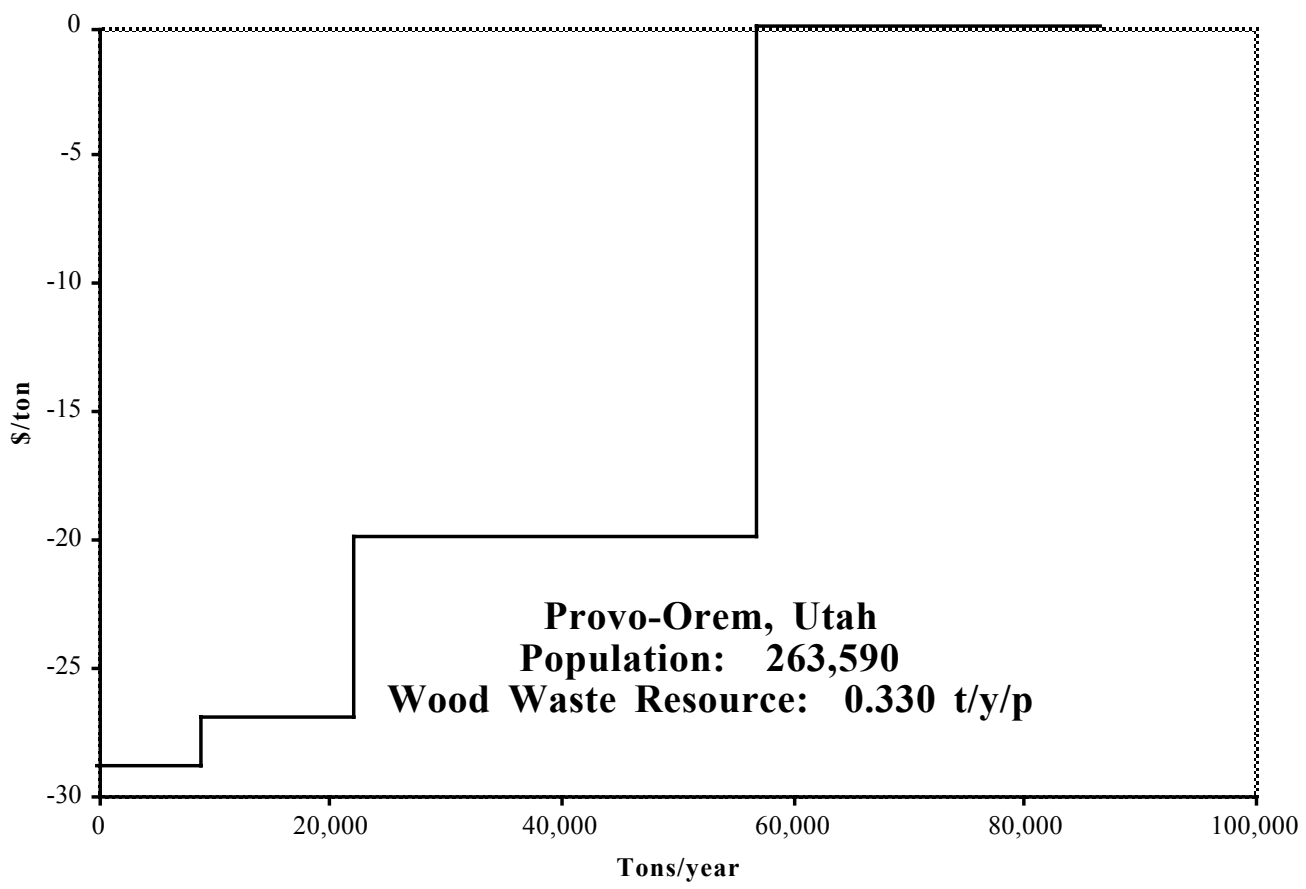

Figure 3-1. Supply Curve for Urban Wood Wastes in Provo-Orem, Utah

Table 3-4

Data and Assumptions Used in Supply Curve for Provo-Orem

Tons/year Cumulative $\$$ /ton Assumptions/Comments

9,000

13,000

35,000

29,900
9,000

22,000

57,000

86,900

\section{$-29$}

$-27$

$-20$

-20
0

Landfilled with MSW \& C/D - South County TS Landfilled with MSW \& C/D - North County TS North County Transfer Station - wood recycling Firewood, mulch, animal bedding - given away 
The Denver-Boulder metropolitan area has a diversified economy with high technology, aerospace, research and development, and traditional industries. A devastating snowstorm in 1995 knocked down trees and limbs all over the metropolitan area. The City of Denver hired a contractor to clean up, grind, and sell or dispose of the wood waste. Hundreds of thousands of cubic yards of wood chips were accumulated at the shut-down Stapleton airport. What could not be sold was given away as landscaping material. Large piles of wood chips still sit at Stapleton, to be used in landscaping as the site is redeveloped. I visited Denver in October 1997 during the cleanup from a snowstorm that again damaged trees throughout the metropolitan area. The activity was noticeable everywhere, but the amount of wood waste generated by the 1997 storm was much less than in 1995.

Table 4-1 summarizes the data collected on urban wood resources in the Denver-Boulder area. The estimated total resource, 0.313 tons/year/person, is just below the weighted average of 0.333 tons/year/person for the 30 metropolitan areas surveyed; the range for the 30 cities is from 0.156 to 0.829 tons/year/person. Wood recycling around Denver is constrained by very low landfill tipping fees, and by the lack of large markets for wood fuel or furnish in the region. Large amounts of wood are hauled to wood processors who charge about $\$ 12 /$ ton, or to landfills where tipping fees for wood are $\$ 18-22 /$ ton. A biomass project developer could probably secure about 300,000-500,000 tons/year of feedstock at close to zero cost, and could produce 20-50 MW of electricity.

Table 4-1

Resource Estimate for Urban Wood Waste in Denver-Boulder, Colorado

\begin{tabular}{|c|c|c|c|c|c|}
\hline \multirow[b]{2}{*}{ Use or Disposal Method: } & \multicolumn{4}{|c|}{ Tons/Year } & \multirow[b]{2}{*}{$\begin{array}{c}\text { Price, } \\
\$ / \text { ton }\end{array}$} \\
\hline & $\begin{array}{l}\text { MSW } \\
\text { Wood }\end{array}$ & $\begin{array}{c}\text { Industr. } \\
\text { Wood }\end{array}$ & $\underset{\text { Wood }}{\text { C/D }}$ & Total & \\
\hline Animal bedding & & 7,800 & & 7,800 & 0 \\
\hline Firewood & 33,000 & 600 & & 33,600 & 0 \\
\hline Mulch and compost & 108,000 & 63,000 & & 171,000 & 0 to -13 \\
\hline Landfill & 200,000 & 6,600 & 160,000 & 366,600 & -18 to -22 \\
\hline Total & 341,000 & 78,000 & 160,000 & 579,000 & \\
\hline Total, tons/year/person & 0.184 & 0.042 & 0.087 & 0.313 & \\
\hline
\end{tabular}

\section{Municipal Solid Waste (MSW) Collection and Disposal}

Of the fifteen major cities and parts of five counties that comprise the Denver-Boulder metropolitan area, only four provide trash pickup services through a public agency. Fierce competition exists among the leading waste management companies, Waste Management, Inc., BFI, USA Waste, and Laidlaw. Each of these companies owns and operates at least one major landfill near Denver. Table 4-2 shows the quantities of solid waste disposed of at the seven major landfills in the Denver-Boulder area during 1996. Most of the landfill owners report their disposal quantities in cubic yards only. The total for 1996 was over 4.7 million cubic yards. A BFI manager told me that the Tower Road landfill receives about 2 million tons/year and the Foothills landfill receives about 1.5 million tons/year. The new USA Waste Front Range landfill is scheduled to receive 3.5 million tons/year. 
Table 4-2

MSW Disposal Rates at Denver-Boulder Area Landfills, 1996

\begin{tabular}{|c|c|c|c|c|c|}
\hline County & Landfill & Owner & $\begin{array}{l}\text { Tip Fee } \\
\$ / \text { cu yd }\end{array}$ & $\begin{array}{l}\text { Cubic } \\
\text { Yards }\end{array}$ & Tons \\
\hline$\overline{\text { Adams }}$ & $\overline{\text { Frei }}$ & Albert Frei \& Sons & & 112,037 & \\
\hline Adams & Tower Road & BFI & 5.50 & $1,685,099$ & \\
\hline Arapahoe & DADS (Lowry) & Waste Mgmt Inc. & 5.45 & $1,226,051$ & 982,877 \\
\hline Jefferson & Foothills & BFI & 6.00 & 870,409 & \\
\hline Weld & Laidlaw South & Laidlaw & 6.65 & 380,249 & 548,971 \\
\hline Weld & North Weld & Waste Mgmt Inc. & & 438,631 & \\
\hline Weld & $\begin{array}{l}\text { Front Range } \\
\text { Total }\end{array}$ & USA Waste & 6.00 & $\begin{array}{r}25,835 \\
4,738,311\end{array}$ & 77,239 \\
\hline
\end{tabular}

The Colorado Department of Public Health and Environment report from which I obtained the data in Table 4-2 gave a conversion factor of 3.333 cubic yards per ton. That would give a total of about 1.4 million tons/year of MSW, or about 0.77 tons/year/person. While this figure is very close to the EPA national average figure, it is not consistent with the information given to me by the waste management companies. Landfill tipping fees are in the range of $\$ 5.45$ to $\$ 6.65$ per cubic yard. For loads of wood, these are equivalent to about $\$ 18-22 /$ ton. The following tipping fees per ton for large loads were mentioned: \$7.75/ton at the DADS landfill; \$6-9/ton at the WMI South Metro transfer station; \$1020/ton at the USA Waste landfill.

In the City of Denver, about 240,000 tons/year of residential trash is collected by city trucks. Wood (up to 4 inches in diameter, 4 feet in length, bundled and tied) is collected in the same trucks and hauled to the landfill with no separation or recycling. There is no wood separation or recycling at the transfer station; paper, plastics, metals, and glass are separated and recycled. The remaining trash is compacted and and hauled to the landfill. At the DADS landfill, wood wastes are simply landfilled. Treated wood, such as railroad ties or telephone poles, is tested for creosote, manifested, and sent to hazardous waste disposal sites. A lot of C/D debris enters the landfill, but no records are kept other than the total quantities entering. The new USA Waste landfill also receives a lot of C/D debris, perhaps about $40 \%$ of their total, about $20 \%$ of which is estimated to be wood. The City of Commerce also provides residential trash hauling service, and uses Laidlaw as the contractor. The City of Thornton hauls residential trash to the BFI Tower Road landfill. Wood wastes in both cities are handled the same way as in Denver -- landfilled.

I have assumed that (1) the total amount of solid waste landfilled in the Denver-Boulder area is about 4 million tons/year; (2) about $20 \%$, or 800,000 tons/year of this is C/D debris; (3) the municipal solid waste contains about $5 \%$ wood by weight; and (4) the C/D debris contains about $20 \%$ wood by weight. Based on these assumptions and the information above, my estimates of the amounts of wood waste entering landfills along with the solid waste in the Denver-Boulder metropolitan area are approximately:

MSW wood: $5 \%$ of 3,200,000 $=160,000$ tons/year;

C/D wood: $20 \%$ of $800,000=160,000$ tons/year.

\section{MSW Wood (Primarily Tree and Yard Wastes)}

Four large companies in the Denver-Boulder area process wood wastes and sell products such as mulch and furnish: A-1 Organics, Construction Recycling Company, Renewable 
Fiber Company, and Jensen Sales. A-1 Organics processes about 60,000 tons/year of waste wood, about $60 \%$ of which is waste pallets from accounts such as Coors Brewery, and $40 \%$ is urban tree wastes. A-1 charges a tipping fee of $\$ 3.50 /$ cubic yard (about $\$ 12 /$ ton of wood). My estimate of MSW wood processed by A-1 is 24,000 tons/year. Construction Recycling Company grinds about 24,000 tons/year of commingled industrial and tree waste wood, which I estimate to be 50\% industrial and 50\% MSW wood. The manager at Construction Recycling estimated that the total market for mulch in the DenverBoulder metropolitan area is about 250,000 cubic yards/year, which is about 76,000 tons/year. Renewable Fiber Company (which also owns a company called Wes Moser \& Sons) processes or markets about 60,000 tons/year of sawmill wastes from regional sawmills (this is not urban wood waste). Several of their big customers for this material have gone out of business: a Medite particle board plant in New Mexico, and a paper plant in Arizona. Renewable Fiber also grinds pallet and truss wastes and produces animal bedding for turkey farms and playground material under a license from FiBar Corporation. Renewable Fiber also grinds about 12,000 tons/year of metropolitan area tree wastes, which is the amount I included in the MSW wood waste estimate. Jensen Sales produces about 5,000 tons/year of mulch from industrial wood wastes and about 7,000 tons/year from MSW wood waste. Jensen Sales charges a tipping fee of $\$ 4$ per cubic yard (about $\$ 13 /$ ton of wood).

The total amount of mulch produced by these four wood processors is about 55,000 tons/year. The primary source of the tree wastes used in generating this mulch is private tree service companies. In the summary table below, this material is included in the 90,000 tons/year of mulch estimated for the Denver-Boulder area tree service companies.

Public Service Company of Colorado provides electric service to the entire Denver-Boulder metropolitan area (and to most of the rest of Colorado). PSCo's tree trimming work is handled by two contractors, Wright Tree Service and Asplundh. Their wood waste generation in the Denver-Boulder metro area is estimated at 11,000 tons/year of chips and 3,000 tons/year of firewood. They leave as much of the mulch on the land as possible.

The City of Aurora arborist reported that his tree trimming operations on city streets and parks generate about 1,000 tons/year of chips. I assumed this was typical of the metro area as a whole, leading to an estimate of 7,000 tons/year of chips from city parks and rights-ofway. (Aurora has a population of about 250,000 , or about $1 / 7$ th of the total metro area.)

Denver Metropolitan Wastewater District has a very limited program of blending wood chips with biosolids (sludge) to produce compost. About $1-2 \%$ of the biosolids is used in this way, and the wood consumption is about 1,400 tons/year. This wood mulch is provided by tree service companies; I assumed this wood is accounted for in the estimate for tree service companies.

Discussions with firewood companies confirmed that a large amount of Denver's urban wood waste is used as firewood. This wood, which is mostly elm, is referred to as "mixed hardwood". It sells for $\$ 120-\$ 150$ /cord, as compared to oak, which is brought up from tree farms in places like Trinidad, Colorado, and sells for about $\$ 250 /$ cord.

The Denver-Boulder Yellow Pages list 150 tree service companies, 66 of which have large ads. I called 51 of these companies, found that 5 of these were no longer in business, and obtained resource estimates from 15 companies. This included the five tree service companies I believe to be the largest in Denver: Swingle Tree \& Landscape Care, Denver Tree Specialists, Aesthetic Tree Service, Colorado Tree \& Shrub Specialists, and Cedar Canyon Tree Care. Each of these companies generates on the order of 2,000-5,000 tons/year of wood wastes, most of which are ground to mulch and the remainder cut to 
firewood. The other ten companies each generate between 100 and 1,000 tons/year. My total estimate for the fifteen companies is about 20,000 tons/year, of which 6,000 tons/year (about 30\%) was specifically identified as going to landfills. Based on this information I estimate that a total of about 160 tree service crews operate in the Denver-Boulder area, generating about 160,000 tons/year of wood from tree trimming and removals. At least $25 \%$ of this material is landfilled; my estimate is 40,000 tons/year to landfills, 90,000 tons/year given away as mulch, and 30,000 tons/year given away or sold as firewood.

Table 4-3 summarizes the estimated resources of MSW wood in Denver-Boulder, Colorado. The total estimate, 341,000 tons/year (of which 200,000 tons/year enter landfills), is equivalent to 0.184 tons/year/person based on the metropolitan area population of 1,848,319. This is below the weighted average of 0.209 tons/year/person of MSW wood for the 30 metropolitan areas, which range from 0.134 to 0.538 tons/year/person.

\section{Table 4-3 \\ Resource Estimate for MSW Wood in Denver-Boulder, Colorado Tons/year}

\begin{tabular}{|c|c|c|c|c|}
\hline & Mulch & Firewood & Landfill & Total \\
\hline Hauled with trash & & & 160,000 & 160,000 \\
\hline Municipal yard waste recycl. & 7,000 & & & 7,000 \\
\hline Utility tree trimming & 11,000 & 3,000 & & 14,000 \\
\hline Private tree service co's & 90,000 & 30,000 & 40,000 & 160,000 \\
\hline Total (rounded) & 108,000 & 33,000 & 200,000 & 341,000 \\
\hline
\end{tabular}

\section{Industrial Wood Wastes}

The four wood recycling operations discussed above produce the following estimated amounts of ground wood products (mostly mulch, animal bedding, and colored wood chips) from industrial wood wastes such as pallets and trusses:

\begin{tabular}{lr} 
A-1 Organics & 36,000 tons/year \\
Construction Recycling & 12,000 \\
Renewable Fibers & 12,000 \\
Jensen Sales & 5,000 \\
\cline { 2 - 2 } \multicolumn{1}{c}{ Total } & 65,000 tons/year
\end{tabular}

The primary generators of the industrial wood wastes delivered to these wood processors are pallet companies, truss companies, and wholesale lumber companies. My estimates of the amounts of wood wastes received from these three main categories of industrial wood waste generators are 50,000 tons/year from pallet companies, 5,000 tons/year from truss companies, and 10,000 tons/year from wholesale lumber companies.

The Denver-Boulder Yellow Pages list 27 companies under Pallets and Skids; three companies under Trusses-Construction; 16 companies under Lumber-Wholesale; 37 companies under Lumber-Retail; and 101 companies under Hardwood (Floors), Cabinet Makers, Furniture Designers \& Custom Builders, and Furniture Manufacturers (woodworking companies). I called the 13 pallet companies with big ads and obtained information from six. These six companies send an estimated 2,100 tons/year to the landfill and 1,800 tons/year to wood recycling companies (probably but not necessarily 
those listed above). The resulting estimate for pallet companies in the Denver-Boulder metropolitan area is 6,000 tons/year of wood waste to landfills and 4,000 tons/year recycled to mulch and other products. I assumed the latter is in addition to the amounts estimated for the large wood processing companies above.

The retail lumber companies in the area generate very small quantities of waste wood. I estimate that about 200 tons/year go to landfills, 600 tons/year to animal bedding, and 200 tons/year to firewood. Woodworking companies generate about 400 tons/year of wood waste to landfills, 1,200 tons/year of animal bedding, and 400 tons/year of firewood.

Table 4-4 summarizes the estimated resources of industrial wood wastes in the DenverBoulder metropolitan area. The total estimate of 78,000 tons/year is equivalent to 0.042 tons/year/person based on the metropolitan area population of 1,848,319. This is below the weighted average of 0.048 tons/year/person of industrial wood waste for the 30 metropolitan areas surveyed; the range is from 0.001 to 0.488 tons/year/person.

Table 4-4

Resource Estimate for Industrial Wood Wastes in Denver-Boulder, Colorado Tons/year

\begin{tabular}{|c|c|c|c|c|c|}
\hline & Mulch & $\begin{array}{c}\text { Animal } \\
\text { Bedding }\end{array}$ & Landfill & $\begin{array}{l}\text { Fire- } \\
\text { wood }\end{array}$ & Total \\
\hline Pallet companies & 50,000 & 4,000 & 6,000 & & 60,000 \\
\hline Truss companies & 4,000 & 1,000 & & & 5,000 \\
\hline Whlsl lumber co's & 9,000 & 1,000 & & & 10,000 \\
\hline Retail lumber co's & & 600 & 200 & 200 & 1,000 \\
\hline Woodworking co's & & 1,200 & 400 & 400 & 2,000 \\
\hline Total & 63,000 & 7,800 & 6,600 & 600 & 78,000 \\
\hline
\end{tabular}

\section{Construction/Demolition Wood Wastes}

The Denver-Boulder Yellow Pages list 42 demolition contractors and eight land clearing and leveling companies, of which I spoke to four and two, respectively. These companies all haul their wastes to landfills and do not know how much wood is included. None of these companies was able to give me an estimate of the total amount of waste they hauled. Renewable Fiber Company, a large wood processor, stated that they recently quit taking construction debris because the percentage of wood has dropped to the $10 \%$ range (from $60 \%$ a few years ago) due to the new construction techniques, in which much of the assembly takes place in factories.

As discussed above in the section on MSW collection and disposal, if we assume that the total MSW stream in Denver is about 4 million tons/year, and that $20 \%$ of this is C/D debris, and that $20 \%$ of the $\mathrm{C} / \mathrm{D}$ debris is wood, the resulting estimate is 160,000 tons/year of C/D wood. This is equivalent to 0.087 tons/year/person based on the Denver-Boulder metropolitan area population of $1,848,319$. This is just above the weighted average of 0.076 tons/year/person of C/D wood for the 30 metropolitan areas surveyed; the range is from 0.015 to 0.250 tons/year/person. 


\section{Supply Curve}

Figure 4-1 shows the supply curve for urban wood wastes in the Denver-Boulder area. Table 4-5 shows the data and assumptions used to produce the supply curve.

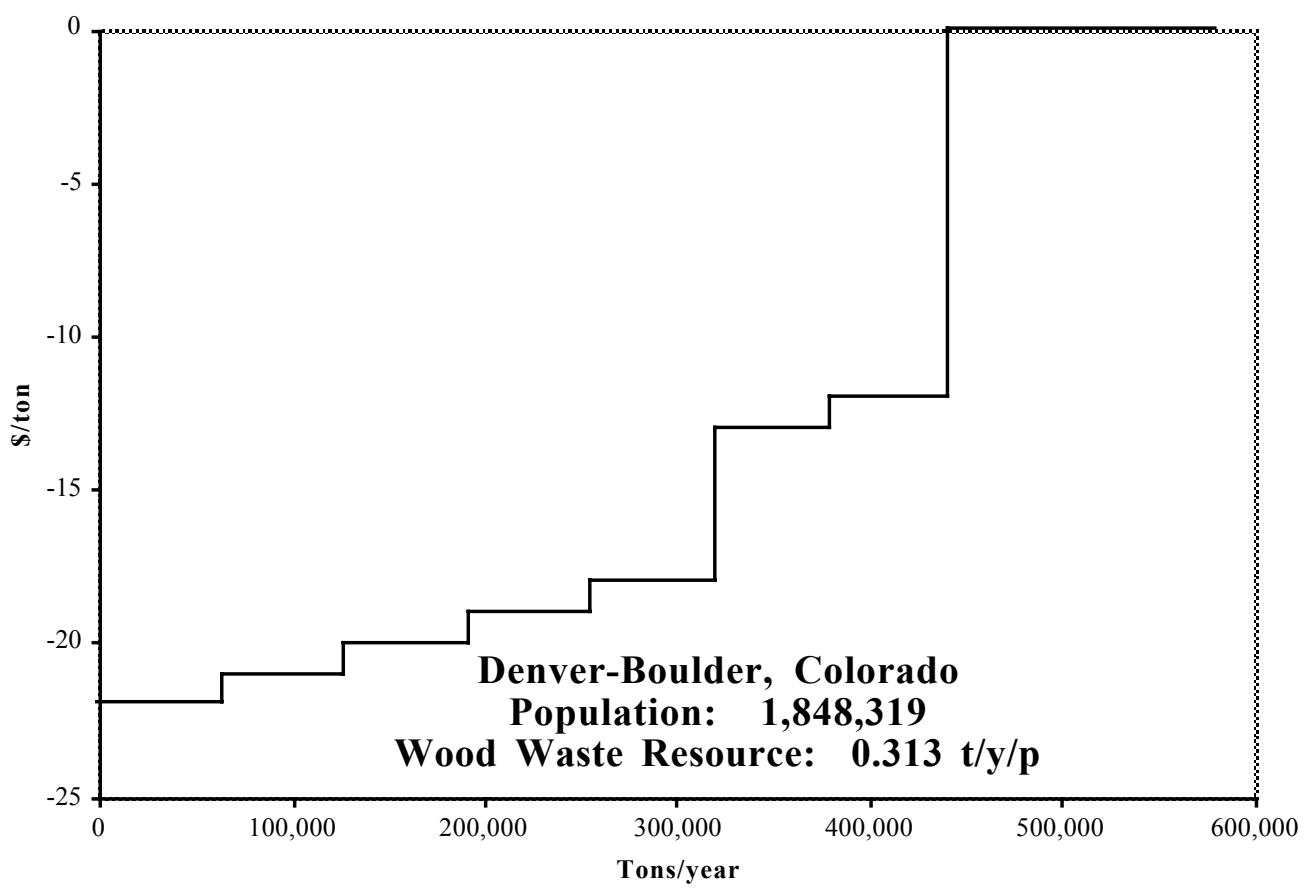

Figure 4-1. Supply Curve for Urban Wood Wastes in Denver-Boulder, Colorado

Table 4-5

Data and Assumptions Used in Supply Curve for Denver-Boulder

Tons/year Cumulative $\frac{\text { \$/ton }}{64,000}$

$64,000 \frac{64,000}{-22}$

64,000

64,000

64,000

64,000

60,000

60,000

139,000
128,000

192,000

256,000

320,000

380,000

440,000

579,000
Assumptions/Comments

Landfilled with MSW and C/D debris

-21 Landfilled with MSW and C/D debris

-20 Landfilled with MSW and C/D debris

-19 Landfilled with MSW and C/D debris

-18 Landfilled with MSW and C/D debris

-13 Wood processors - tree wastes, industrial wood

-12 Wood processors - tree wastes, industrial wood

0 Firewood, mulch, animal bedding - given away 
Lincoln was established as the state capital when Nebraska became a state in 1867. Lincoln is south of the Platte River and about 50 miles southwest of Omaha, which is a larger, more commercial city located on the Mississippi River. Given its Great Plains location on the frontier, Lincoln's early years were hard and development slow. The University of Nebraska evolved into the city's cultural nucleus, a role it still maintains.

A devastating storm passed through Lincoln (as well as Denver and Omaha) just before I arrived, destroying many of the city's trees. Every city street I saw was a jumble of fallen trees and branches, attended by people from all walks of life with chainsaws, loading trucks and trailers that carried the tens of thousands of tons of woody debris to four major collection sites. At those sites the National Guard along with tree service companies and city and county crews were managing the growing piles, running tub grinders, and carrying truckloads of shredded wood away to disposal sites, primarily the city/county landfill. Lincoln Electric Service crews were working almost around the clock, repairing hundreds of broken power lines that had led to the shutdown of homes, schools and many businesses. All this was taking place in freezing temperatures amid howling, swirling winds up to 60 miles/hour. Two quotes from newspaper articles follow:

"Before it was the Cornhusker State, Nebraska was the Tree Planter State. Settlers arriving in the $19^{\text {th }}$ century softened the featureless horizon, blocked the wind and anchored the rich prairie soil by planting thousands of trees." [USA Today, November 3, 1997]

"Some Lincoln residents may find it hard to believe the city will ever get its beautiful green canopy back after last weekend's snowstorm. The storm and its 13 inches of wet snow damaged roughly 100,000 city-owned trees and thousands of privately-owned trees. City officials estimate as many as 25,000 trees may have to be cut down. City foresters and other tree experts say the city will recover, but it will take years -- perhaps two or three." [Lincoln Journal Star, November 2, 1997]

The natural disaster cleanup in Lincoln made the point that a large fraction of urban wood wastes produced over a decade-scale period of time results from storms and other natural events. Many of the people I would have liked to interview at greater length simply did not have time. Nevertheless, they seemed to welcome my presence, graciously took time away from their pressing tasks to answer my questions, and in many cases conveyed a sense of wishing I (or somebody) could provide some helpful suggestions or answers. This was frustrating, in that the only solutions I could suggest to correct Lincoln's fundamental lack of markets for waste wood would require new regulations, financial incentives, and sufficient time for new businesses to grow. My emphasis in interviews was on the normal, "business-as-usual" handling of urban wood resources in the Lincoln metropolitan area.

Table 5-1 summarizes the data collected on urban wood resources in the Lincoln area. The estimated total urban wood waste resource, 0.438 tons/year/person, is above the weighted average of 0.333 tons/year/person for the 30 metropolitan areas surveyed; the range for the 30 cities is from 0.156 to 0.829 tons/year/person. The market for wood wastes around Lincoln is severely constrained by the lack of wood-burning power plants or other large wood-consuming (such as medium-density fiberboard) plants in the region. In my opinion, the resource quantities probably overstate the amount of wood entering the landfill and being given away as mulch, and understate the amount of wood being burned or otherwise disposed of in rural areas. A biomass project developer could probably secure $60,000-80,000$ tons/year of feedstock at close to zero delivered cost, and could produce on the order of 4-8 MW of electricity. 
Table 5-1

Resource Estimate for Urban Wood Waste in Lincoln, Nebraska

\begin{tabular}{|c|c|c|c|c|c|}
\hline \multirow[b]{2}{*}{ Use or Disposal Method: } & \multicolumn{4}{|c|}{ Tons/Year } & \multirow[b]{2}{*}{$\begin{array}{c}\text { Price } \\
\text { \$/ton }\end{array}$} \\
\hline & $\begin{array}{l}\text { MSW } \\
\text { Wood }\end{array}$ & $\begin{array}{l}\text { Industr. } \\
\text { Wood }\end{array}$ & $\begin{array}{c}\text { C/D } \\
\text { Wood }\end{array}$ & Total & \\
\hline Mulch & 36,000 & & & 36,000 & 0 \\
\hline Animal bedding, etc. & & 500 & & 500 & 0 \\
\hline Firewood & 6,700 & 300 & & 7,000 & 0 \\
\hline Open burning (rural) & & & 6,000 & 6,000 & -5 \\
\hline Quarry burial & & & 1,000 & 1,000 & -8 \\
\hline Landfill & 24,000 & 1,100 & 18,000 & 43,100 & -16 \\
\hline Total & 66,700 & 1,900 & 25,000 & 93,600 & \\
\hline Total, tons/year/person & 0.312 & 0.009 & 0.117 & 0.438 & \\
\hline
\end{tabular}

\section{Municipal Solid Waste (MSW) Collection and Disposal}

The City of Lincoln and its entire metropolitan area are located in the center of Lancaster County. From a waste handling (as well as a data collection) point of view, the city and county can be taken as a closed system that represents the metropolitan area (as defined by the Census Bureau) quite well. The City operates two landfill sites: the $48^{\text {th }}$ Street Transfer Station, and the Bluff Road Sanitary Landfill a few miles north of the city. The general public is allowed to use only the $48^{\text {th }}$ Street site. Yard wastes, brush, tires, appliances, and lead-acid batteries must be taken to separate areas at the disposal sites.

Garbage collection is provided by private haulers. Lincoln residents are advised to refer to the Yellow Pages or call the Lincoln Solid Waste Management Association to assist in selecting a hauler. The Yellow pages list an unusually large number of garbage collection and rubbish removal companies (39 in all, 18 of which paid for large ads, and none of which have names that suggest ownership by any of the large national trash haulers).

Burning refuse is a city ordinance violation in Lincoln. However, farmers can obtain permits from the county to burn their own wood wastes, and some construction/demolition companies and land clearing companies haul urban wood wastes from Lincoln to these rural sites for burning. The avoided tipping fees could add up to hundreds of thousands of dollars per year for the larger companies.

Grass and leaves are not allowed in the city landfill. Grass and leaves (which may include brush under one inch in diameter) must be taken to a city-operated compost site at the $48^{\text {th }}$ Street Transfer Station; a disposal fee is charged. From April 1 through November 30, haulers offer a separate weekly pickup for yard wastes for a fee. Citizens are allowed to dispose of tree trimmings, brush, and weeds with their regular trash.

Tipping fees at both city facilities are $\$ 16 /$ ton for garbage and $\$ 14.75 /$ ton for yard wastes delivered by large trucks. Pickup trucks, etc., are charged $\$ 10 /$ load for either garbage or yard wastes brought to the transfer station. There are no facilities at either the transfer station or the landfill for separating wood wastes from other MSW. Officials feel that it would be desirable to establish such a capability, but the lack of markets for the large quantities of wood that could be separated and ground makes it impractical at present. 
During the fiscal year September 1996 through August 1997, about 280,000 tons of MSW were disposed of in the Lincoln landfill (about 1.31 tons/year/person). A separate construction/demolition landfill received approximately 90,000 tons of mostly inert material. Based on the information above, my estimates of the amounts of wood waste entering landfills along with the solid waste in the Lincoln metropolitan area are approximately:

MSW wood: $5 \%$ of $280,000=14,000$ tons/year;

C/D wood: $20 \%$ of $90,000=18,000$ tons $/$ year.

\section{MSW Wood (Primarily Tree and Yard Wastes)}

The Superintendent of Solid Waste Operations in Lincoln estimated that 3,000-4,000 tons of wood waste (brush and tree debris) were processed into mulch at the transfer station and given away to the public. The recycling manager at the Lincoln Public Works \& Utilities Department estimated that his agency and the Parks and Recreation/Forestry Department generate about 6,100 tons/year of wood chips and about 620 tons/year of firewood, both of which are given away to the public. This is primarily from tree trimming operations in city parks and rights-of-way.

The University of Nebraska has two campuses in Lincoln. One of the arborists described their landscaping and wood recycling program. The University reuses all of the mulch produced from its on-campus tree trimming operations. It has not been unusual in recent years for the University to use additional mulch from Lincoln Electric System and private tree service companies. He was unable to estimate the quantity of wood generated and recycled on campus. My estimate is that it is likely to be less than 1,000 tons/year.

I was unable to reach the manager of tree trimming at Lincoln Electric System due to the ongoing emergency recovery operations, but learned from other city officials that the utility gives away most of its wood waste as mulch or firewood. My estimate is that this resource is likely to be less than 1,000 tons/year.

The Lincoln Yellow Pages list 35 tree service companies, 23 of which have large ads. I called all of these companies, reached a knowledgeable person at 15 of them, and obtained resource estimates from eight companies. This included the two tree service companies I believe to be the largest in Lincoln: Hofeling Enterprises Inc. and Tri-Point Tree Service Inc. Each of these two companies generates on the order of 2,000-3,000 tons/year of wood wastes, most of which (probably about $90 \%$ ) is ground to mulch and the remainder cut to firewood. The other six companies generated between 60 tons/year (grinding stumps only and leaving the mulch on site) and about 2,000 tons/year. My total estimate for the eight companies is about 10,600 tons/year, of which 2,600 tons/year (about 25\%) was specifically identified as going to the landfill.

Based on this information I estimate that a total of about 40 tree service crews operate in the Lincoln area, generating about 40,000 tons/year of wood from tree trimming and removals. At least $25 \%$ of this material is landfilled; my estimate is 10,000 tons/year to landfills, 24,000 tons/year given away as mulch, and 6,000 tons/year given away as firewood.

Table 5-2 summarizes the estimated resources of MSW wood in Lincoln, Nebraska. The total estimate, 66,700 tons/year (of which 24,000 tons/year enter the landfill), is equivalent to 0.312 tons/year/person based on the Lincoln metropolitan area population of 213,641 . This is above the weighted average of 0.209 tons/year/person of MSW wood for the 30 metropolitan areas, which range from 0.134 to 0.538 tons/year/person. 


\section{Table 5-2 \\ Resource Estimate for MSW Wood in Lincoln, Nebraska \\ Tons/year}

\begin{tabular}{|c|c|c|c|c|}
\hline & Mulch & Firewood & Landfill & Total \\
\hline Hauled with trash & & & 14,000 & 14,000 \\
\hline Municipal yard waste recycl. & 10,100 & 600 & & 10,700 \\
\hline University of Nebraska & 1,000 & & & 1,000 \\
\hline Utility tree trimming & 900 & 100 & & 1,000 \\
\hline Private tree service co's & 24,000 & 6,000 & 10,000 & 40,000 \\
\hline Total (rounded) & 36,000 & 6,700 & 24,000 & 66,700 \\
\hline
\end{tabular}

\section{Industrial Wood Wastes}

The Lincoln Yellow Pages list nine companies under Pallets and Skids, two companies under Trusses-Construction, one company under Lumber-Wholesale, 14 companies under Lumber - Retail, and 34 companies under Cabinet Makers, Furniture Designers \& Custom Builders, and Furniture Manufacturers (woodworking companies).

Seven of the nine pallet companies provided useful information. Three of these companies are in the Omaha metropolitan area (serving some customers in Lincoln, but rebuilding and recycling pallets in the Omaha area); I did not count their wood wastes, which greatly exceed those of the Lincoln-based companies. Stewart Pallet Recyclers, Lincoln's largest, estimate their wood waste generation at about 500 tons/year. Nearly all of this goes to the landfill; small amounts are occasionally ground up for animal bedding and mulch. The other three Lincoln-based companies who provided information each generate between 50 and 100 tons/year; I used a total of 250 tons/year for these three companies. My total estimate for pallet wastes in Lincoln is about 1,000 tons/year, of which about 800 tons/year go to the landfill and 200 tons/year are ground up for animal bedding and mulch.

One of the two truss companies is in Lincoln and generates about 200 tons/year of wood wastes which are mixed with other trash and hauled to the landfill. The other truss company is in the Omaha metropolitan area.

Ten of the 15 lumber companies provided useful information. They generate from less than one ton/year to about 100 tons/year (Lincoln Lumber Company) of wood wastes each. Nearly all of this is sawdust, which is sold or given away as animal bedding. One company gives its sawdust (about 20 tons/year) to a neighboring scrap metal plant that uses it for oil cleanup. One company uses its wood wastes for heating. My total estimate for the 15 lumber companies in Lincoln is about 200 tons/year of wood waste. About half of this goes to the landfill and the rest is recycled as animal bedding.

The woodworking companies in the Lincoln area produce very small amounts of wood scraps that are used by family and friends and given away as animal bedding or firewood. My estimate for the total amount of wood generated by these companies is 200 tons/year of animal bedding and 300 tons/year of firewood

Table 5-3 summarizes the estimated resources of industrial wood wastes in the Lincoln area. The total estimate of 1,900 tons/year is equivalent to 0.009 tons/year/person based on the Lincoln metropolitan area population of 213,641. This is below the weighted average of 0.048 tons/year/person of industrial wood waste for the 30 metropolitan areas surveyed; the range is from 0.001 to 0.488 tons/year/person. 
Table 5-3

Resource Estimate for Industrial Wood Wastes in Lincoln, Nebraska

Tons/year

\begin{tabular}{|c|c|c|c|c|}
\hline & $\begin{array}{c}\text { Animal } \\
\text { Bedding }\end{array}$ & Landfill & $\begin{array}{l}\text { Fire- } \\
\text { wood }\end{array}$ & Total \\
\hline Pallet companies & 200 & 800 & & 1,000 \\
\hline Truss companies & & 200 & & 200 \\
\hline Lumber companies & 100 & 100 & & 200 \\
\hline Woodworking co's & 200 & & 300 & 500 \\
\hline Total & 500 & 1,100 & 300 & 1,900 \\
\hline
\end{tabular}

\section{Construction/Demolition Wood Wastes}

The Lincoln Yellow Pages list six companies under Demolition Contractors and five companies under Land Clearing \& Leveling. I talked to four of the demolition contractors and one of the land clearing and leveling companies.

One demolition contractor generated about 6,000 tons of wood wastes last year and burned the wood in rural areas to avoid paying tipping fees. Another company hauled its mixed wastes containing an estimated 1,000 tons/year of wood to a quarry, who buried it for a fee that is significantly lower than the \$16/ton landfill tipping fee. A third demolition contractor estimated that it disposed of about 1,000 tons of wood wastes in the landfill. I assumed that the demolition companies that did not provide estimates each generated 1,000 tons/year, giving a total estimate of about 11,000 tons/year for demolition companies.

The one land clearing company I was able to talk to estimated that it sent about 1,000 tons/year of wood wastes to the landfill. I assumed that the other four companies each produced a similar amount, on average, giving a total estimate of about 5,000 tons/year for land clearing companies.

As discussed above under MSW collection and disposal, an estimated 18,000 tons of C/D wood enter the landfill. An estimated 6,000 tons/year are burned in rural Nebraska, and about 1,000 tons/year of $\mathrm{C} / \mathrm{D}$ wood are disposed of in a quarry. The total estimate of 25,000 tons/year for $C / D$ wood wastes in the Lincoln area is equivalent to 0.117 tons/year/person based on the Lincoln metropolitan area population of 213,641. This is above the weighted average of 0.076 tons/year/person of C/D wood for the 30 metropolitan areas surveyed; the range is from 0.015 to 0.250 tons/year/person. 


\section{Supply Curve}

Figure 5-1 shows the supply curve for urban wood wastes in the Lincoln area. Table 5-4 shows the data and assumptions used to produce the supply curve.

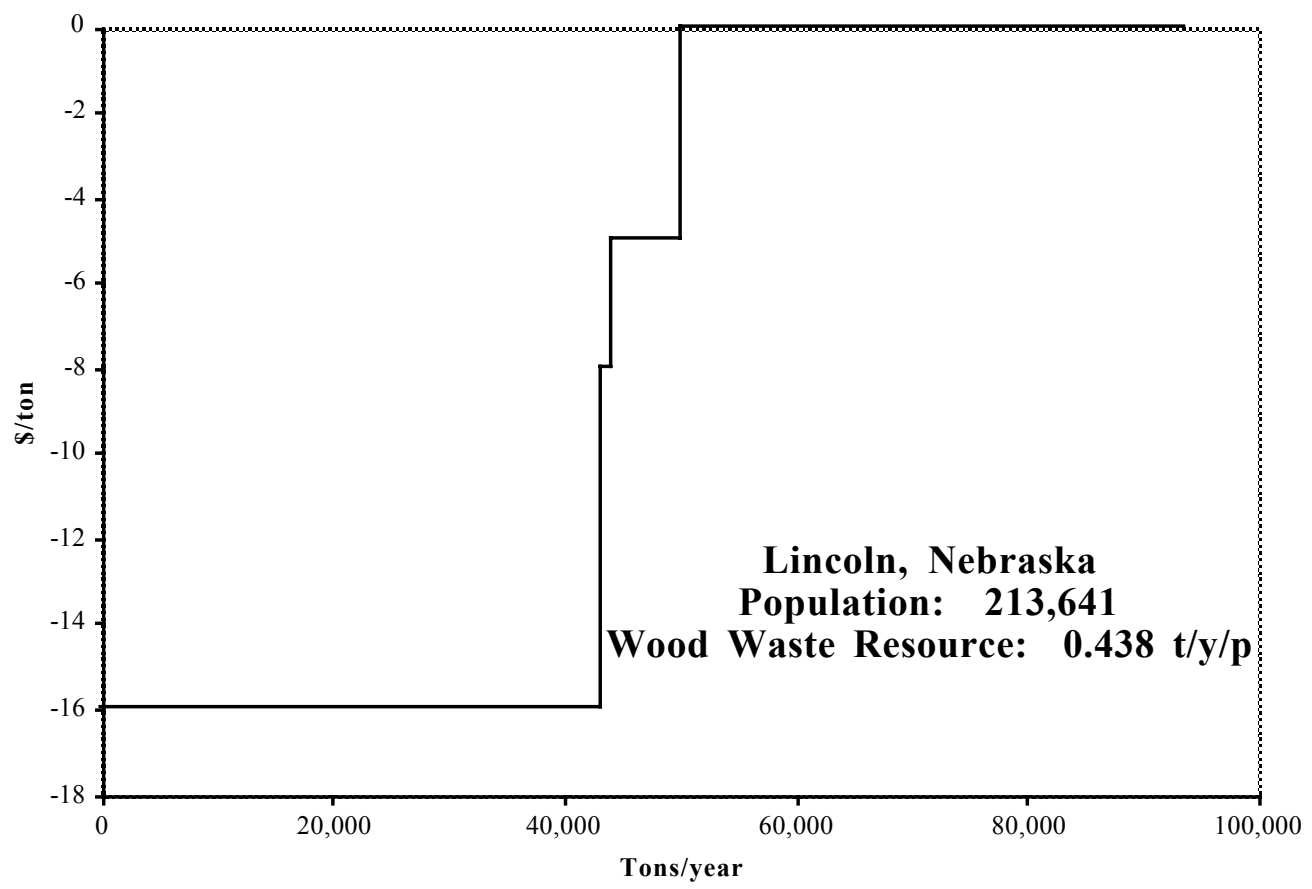

Figure 5-1. Supply Curve for Urban Wood Wastes in Lincoln, Nebraska

Table 5-4

Data and Assumptions Used in Supply Curve for Lincoln

Tons/year Cumulative $\$$ /ton

$43,100 \frac{43,100}{-16}$

Assumptions/Comments

1,000

44,100

Landfilled with MSW and C/D debris

6,000

-8 Quarry burial - C/D wood

43,500

$50,100 \quad-5 \quad$ Open burning - C/D wood

93,600 0 Firewood, mulch, animal bedding - given away 
Bismarck is the capital of North Dakota, and the city of Mandan is across the Missouri River. Together, they comprise nearly all of the metropolitan area, which has relatively little industry. Most of the jobs are in government or service industries, plus the usual commercial and small industrial businesses associated with a small city in a rural area. The economy of North Dakota is primarily agricultural, with major food processing plants and universities in Fargo and Grand Forks on the Red River, about 200 miles east of Bismarck. Bismarck is the smallest of the 30 metropolitan areas in our sample.

Table 6-1 summarizes the data collected on urban wood resources in the Bismarck area. The estimated total urban wood waste resource, 0.235 tons/year/person, is below the weighted average of 0.333 tons/year/person for the 30 metropolitan areas surveyed; the range for the 30 cities is from 0.156 to 0.829 tons/year/person. Power plants in the area burn North Dakota lignite, which is about the lowest-cost coal mined in the US. In comparison, wood waste is an expensive fuel. There are essentially no markets for wood waste around Bismarck, other than free mulch for landscaping and nearly free firewood. Large quantities of wood are piled and burned each year at one of the local landfills. A biomass project developer could probably secure 20,000-30,000 tons/year of feedstock at close to zero delivered cost, and produce 1-3 MW of electricity.

Table 6-1

Resource Estimate for Urban Wood Waste in Bismarck, North Dakota

\begin{tabular}{|c|c|c|c|c|c|}
\hline \multirow[b]{2}{*}{ Use or Disposal Method: } & \multicolumn{4}{|c|}{ Tons/Year } & \multirow[b]{2}{*}{$\begin{array}{l}\text { Price, } \\
\text { \$/ton }\end{array}$} \\
\hline & $\begin{array}{l}\text { MSW } \\
\text { Wood }\end{array}$ & $\begin{array}{c}\text { Industr. } \\
\text { Wood }\end{array}$ & $\begin{array}{c}\text { C/D } \\
\text { Wood }\end{array}$ & Total & \\
\hline Mulch & 5,130 & & & 5,130 & 0 \\
\hline Animal bedding & & 100 & & 100 & 0 \\
\hline Firewood & 270 & 250 & & 520 & 0 \\
\hline Open burning (at landfill) & 5,000 & 100 & 2,500 & 7,600 & -10 \\
\hline Landfill & 3,600 & 250 & 2,500 & 6,350 & -10 to -30 \\
\hline Total & 14,000 & 700 & 5,000 & 19,700 & \\
\hline Total, tons/year/person & 0.167 & 0.008 & 0.060 & 0.235 & \\
\hline
\end{tabular}

\section{Municipal Solid Waste (MSW) Collection and Disposal}

Bismarck and Mandan operate separate trash pickup and disposal systems. In Bismarck, the city picks up residential trash and owns a landfill just east of town. Tipping fees are $\$ 30 /$ ton for regular garbage and \$10/ton for wood, concrete, and dirt. Wood accumulates in large piles, and the city forester auctions off the large pieces as firewood and grinds the rest into mulch. The total amount of MSW disposed of in the Bismarck landfill in 1996 was 49,535 tons, plus 9,755 tons of inert material (such as demolition waste).

Mandan contracts out the residential trash hauling to Dakota Sanitation Co. The city owns a landfill that accepts inert materials only, and a transfer station that compacts the MSW and loads it into trucks that haul it to a landfill in Wishek (about 100 miles southeast). The remote landfill, and the hauling trucks, are owned by American Waste. Mandan's tipping fees at the landfill/transfer station are $\$ 28 /$ ton for regular garbage and $\$ 10 /$ ton for wood and inert materials. The total amount of material disposed of at the Mandan landfill and transfer station in the last twelve months was 29,650 tons. Thus, the total waste stream for the 
Bismarck metropolitan area is about 89,000 tons/year. I estimate that about $20 \%$ of the total is C/D debris, which in turn contains about $28 \%$ wood (to give 5,000 tons/year of C/D wood, as discussed in the C/D section below). Based on the information above, my estimates of the amounts of wood waste entering landfills along with the solid waste in the Bismarck metropolitan area are approximately:

MSW wood: $5 \%$ of $71,000=3,600$ tons/year;

C/D wood: $28 \%$ of $18,000=5,000$ tons/year, of which about half is buried and half is burned at the landfill.

\section{MSW Wood (Primarily Tree and Yard Wastes)}

Montana-Dakota Utilities contracts out its tree trimming work to Bullinger Tree Service Company in Mandan, and was not able to provide an estimate of the amount of wood waste generated. Bullinger Tree Service also performs tree removal and trimming work for the city of Mandan and for a variety of commercial and residential accounts. The company operates 11 months a year with four commercial crews and one residential crew. Based on discussions with the owner I believe a reasonable estimate is 9,100 tons/year of wood waste generated from tree trimming and removals. Of that, roughly $50 \%$ goes to the landfill and $50 \%$ goes to mulch.

Of the twelve other companies listed in the yellow pages under Tree Service, only six actually perform tree removal or trimming work. I was only able to obtain data from one of these companies, but believe that all of them are very small companies. A very rough estimate is that these six companies together generate 900 tons/year of wood waste, which when added to Bullinger's estimated amount brings the total for tree service companies to about 10,000 tons/year.

The Bismarck city forester removes trees and limbs from city streets and parks. All elm is buried in the landfill as part of a Dutch elm disease program. All other wood is processed to firewood and mulch. The city's equipment is capable of chipping logs up to 12 inches in diameter. Uncut logs destined to be used for firewood are piled at the landfill in small piles equivalent to 3-5 cords each. In August the city invites sealed bids from the public, and the firewood is auctioned off. The successful bidders cut the wood and haul it away. The number of cords sold in the last three auctions was 87 in 1995, 203.5 in 1996, and 111 in 1997. Average prices were $\$ 8.00$ /cord in $1995, \$ 4.60 /$ cord in 1996 , and $\$ 8.70 /$ cord in 1997. In 1996, 140 cords were not sold, and had to be burned at the landfill; the volume of wood was unusually high that year because of two major storms.

The Bismarck city forester estimated the current size of the wood mulch pile at the landfill to be 20 feet wide by 40 feet long by 10 feet high, which is a volume of about 300 cubic yards. The city uses some of the mulch in its own landscaping projects, and makes the mulch available to the public. In summary, I estimate that the city forester in Bismarck generates about 200 tons/year of firewood and 100 tons/year of mulch from tree trimming operations in city rights-of-way and parks.

The Mandan city forester estimated that he generates about $1 / 4$ as much wood as the Bismarck city forester. I translated this to an estimate of about 100 tons/year -- 70 to firewood and 30 to mulch.

The Mandan inert landfill attracts much more wood waste than the Bismarck landfill for some reason (the tipping fees are the same -- \$10/ton for wood). A very large pile of wood accumulates, and twice a year the wood is burned and the ash is buried. A rough estimate of the size of the pile is 75 feet wide, 150 feet long, and 30 feet deep. This is equivalent to 
about 12,500 cubic yards. Two piles of this size per year would represent about 7,500 tons/year of wood waste. This wood comes from all sources (MSW, industrial, and C/D), and is not included as a separate item in the tables because that would be double-counting.

Table 6-2 summarizes the estimated resources of MSW wood in the Bismarck area. The total estimate, 14,000 tons/year (of which 8,600 tons/year enter the landfill), is equivalent to 0.167 tons/year/person based on the Bismarck metropolitan area population of 83,831 . This is below the weighted average of 0.209 tons/year/person of MSW wood for the 30 metropolitan areas, which range from 0.134 to 0.538 tons/year/person.

\section{Table 6-2 \\ Resource Estimate for MSW Wood in Bismarck, North Dakota Tons/year}

\begin{tabular}{|c|c|c|c|c|}
\hline & Mulch & Firewood & Landfill & Total \\
\hline Hauled with trash & & & 3,600 & 3,600 \\
\hline $\begin{array}{l}\text { Municipal yard waste recycl. } \\
\text { Private tree service co's* }\end{array}$ & $\begin{array}{r}130 \\
5,000\end{array}$ & 270 & $5,000 * *$ & $\begin{array}{r}400 \\
10,000\end{array}$ \\
\hline Total & 5,130 & 270 & 8,600 & 14,000 \\
\hline
\end{tabular}

\section{Industrial Wood Wastes}

The Bismarck-Mandan Yellow Pages list two local companies under Pallets and Skids, three companies under Trusses-Construction, no companies under Lumber-Wholesale, nine companies under Lumber-Retail, and four companies under Cabinet Makers, Furniture Designers \& Custom Builders, and Furniture Manufacturers (woodworking companies).

One of the two pallet companies provided useful information. Basically it is a trucking firm that has developed a side business in pallets, primarily as a way to provide better service to its customers. The amount of wood waste generated from the pallet repair activities is less than 100 tons/year. Most of that wood waste is taken by employees for use as firewood. A small amount of rotten or waterlogged wood is landfilled. My guesstimate for the total amount of pallet wood waste generated in the Bismarck area is 200 tons/year.

Two of the three truss companies provided useful information. One of them hauls about 100 tons/year to the Mandan landfill, where the wood waste is burned. The other truss company generates about 40 tons/year of waste, some of which is taken home as firewood; the remainder is hauled with the trash to the landfill. My guesstimate for the total amount of truss wood waste generated in the Bismarck area is 200 tons/year.

Five of the nine lumber companies provided useful information. They generate from less than one ton/year to about 100 tons/year of wood wastes each. Nearly all of this is small pieces and sawdust, most of which is landfilled. My total estimate for the nine lumber companies in the Bismarck area is about 300 tons/year of wood waste. About two-thirds of this goes to the landfill and the rest is recycled as animal bedding. The amount of wood waste generated by the woodworking companies in Bismarck is much less than 100 tons/year and is not included in the table below. 
Table 6-3 summarizes the estimated resources of industrial wood wastes in the Bismarck area. The total estimate of 700 tons/year is equivalent to 0.008 tons/year/person based on the Bismarck metropolitan area population of 83,831. This is below the weighted average of 0.048 tons/year/person of industrial wood waste for the 30 metropolitan areas surveyed; the range is from 0.001 to 0.488 tons/year/person.

Table 6-3

\section{Resource Estimate for Industrial Wood Wastes in Bismarck, North Dakota Tons/year}

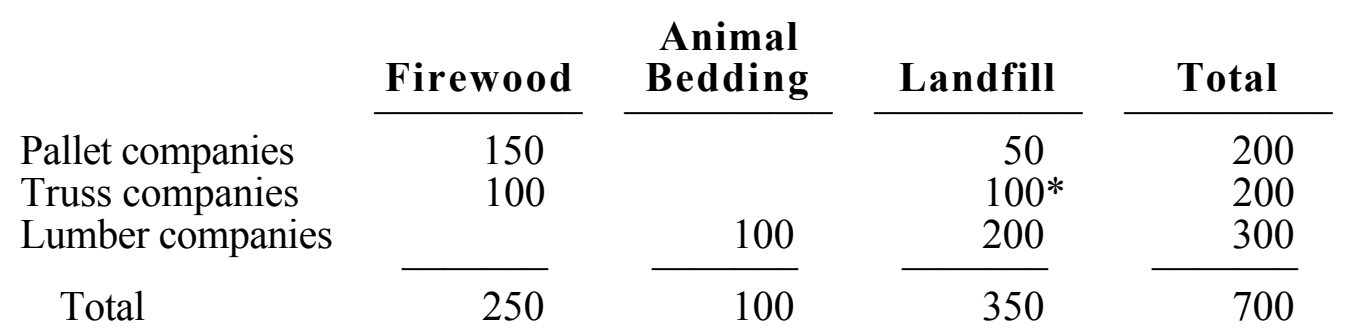

*Assumed to be burned at the Mandan landfill.

\section{Construction/Demolition Wood Wastes}

The Bismarck-Mandan Yellow Pages list two companies under Demolition Contractors and no companies under Land Clearing \& Leveling. I called the two demolition companies and was unsuccessful in getting through to managers who could provide useful information.

Based on information provided by personnel at the Mandan inert landfill I believe it is reasonable to estimate a total of about 5,000 tons/year for $\mathrm{C} / \mathrm{D}$ wood wastes in the Bismarck area. I estimate that about half of the C/D wood is separated and burned at the Mandan landfill; the other half remains mixed with other construction materials and is buried in the landfill. The estimated total of 5,000 tons/year is equivalent to 0.060 tons/year/person based on the Bismarck metropolitan area population of 83,831. This is below the weighted average of 0.076 tons/year/person of $C / D$ wood for the 30 metropolitan areas surveyed; the range is from 0.015 to 0.250 tons/year/person. 


\section{Supply Curve}

Figure 6-1 shows the supply curve for urban wood wastes in the Bismarck area. Table 6-4 shows the data and assumptions used to produce the supply curve.

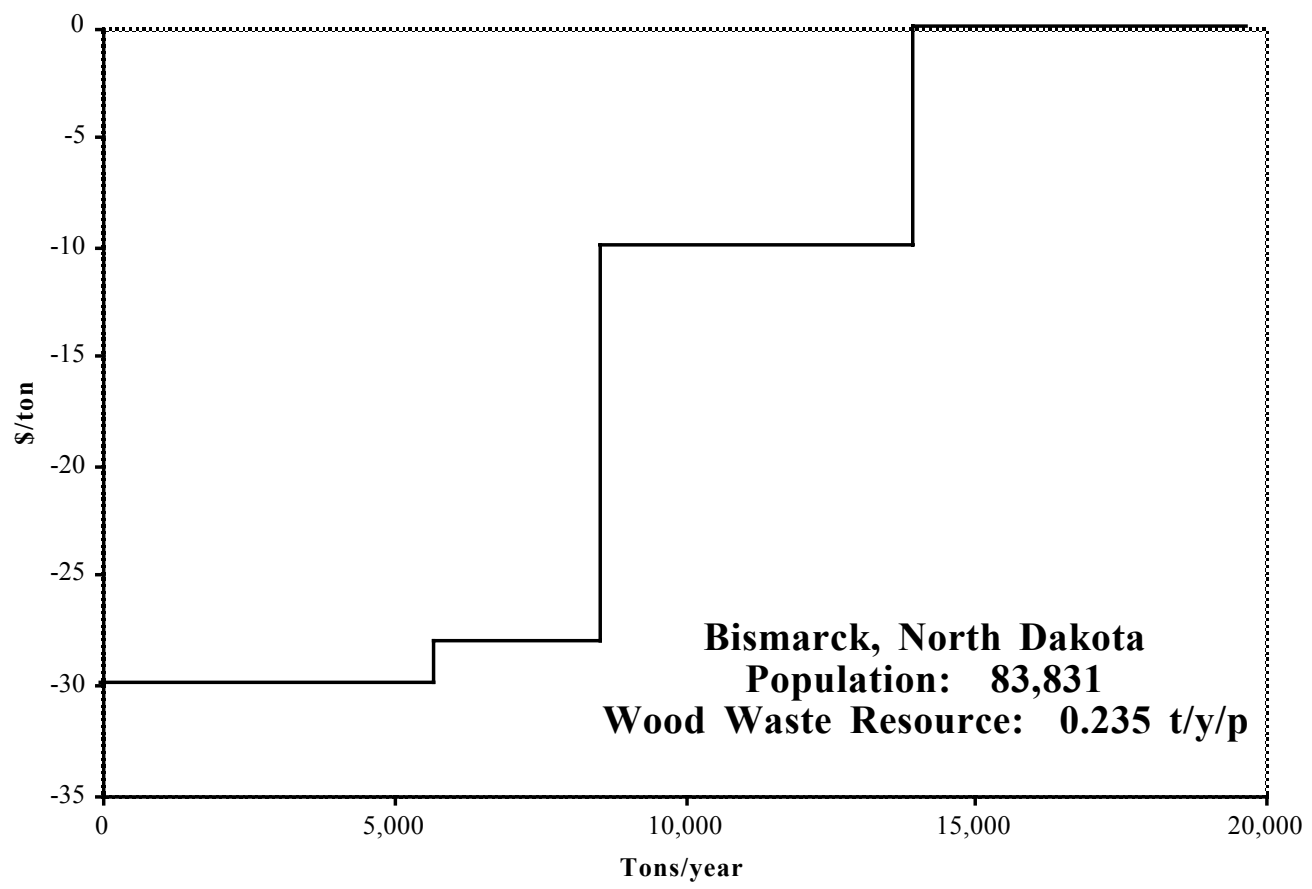

Figure 6-1. Supply Curve for Urban Wood Wastes in Bismarck, North Dakota

\section{Table 6-4}

Data and Assumptions Used in Supply Curve for Bismarck

Tons/year Cumulative $\frac{\$ / \text { ton }}{5,700}$ Assumptions/Comments

5,700

2,900

5,350

5,750
$5,700 \frac{\$}{-30}$

$8,600-28$

13,950

19,700

$-10$

Landfilled with MSW and C/D debris - Bismarck

Landfilled with MSW and C/D debris - Mandan

Landfill - wood processing \& burning

Firewood, mulch, animal bedding - given away 
Bloomington and Normal share Franklin Avenue, which has a university at each end: Illinois State and Illinois Wesleyan. Local television stations use the slogan "The Heart of Illinois" and refer to Bloomington-Normal as the "twin cities." Manufacturing facilities around the metropolitan area and surrounding McLean County generate a significant amount of industrial wood wastes. Most of the wood wastes in the metropolitan area are processed by Twin City Wood Recycling, which appears to be drowning in its own processed wood wastes. A pallet company in Bloomington is obtaining permits to operate a combustion system to dispose of its pallet wood wastes. Illinois Power Company's Research \& Development Department has been evaluating the possibility of cofiring wood at two of its coal-fired plants, but these plants are close to large cities (such as St. Louis), and thus are not likely to attract wood wastes from Bloomington-Normal.

Table 7-1 summarizes the data collected on urban wood resources in the BloomingtonNormal area. The estimated total urban wood waste resource, 0.379 tons/year/person, is above the weighted average of 0.333 tons/year/person for the 30 metropolitan areas surveyed; the range for the 30 cities is from 0.156 to 0.829 tons/year/person. The market for wood wastes around Bloomington-Normal is constrained by the lack of demand for wood. A biomass project developer could probably secure 35,000-45,000 tons/year of feedstock at close to zero delivered cost, and produce 2-5 MW of electricity.

Table 7-1

Resource Estimate for Urban Wood Waste in Bloomington-Normal, Illinois

\begin{tabular}{|c|c|c|c|c|c|}
\hline \multirow[b]{2}{*}{ Use or Disposal Method: } & \multicolumn{4}{|c|}{ Tons/Year } & \multirow[b]{2}{*}{$\begin{array}{c}\text { Price } \\
\text { \$/ton }\end{array}$} \\
\hline & $\begin{array}{l}\text { MSW } \\
\text { Wood }\end{array}$ & $\begin{array}{c}\text { Industr. } \\
\text { Wood }\end{array}$ & $\begin{array}{c}\text { C/D } \\
\text { Wood }\end{array}$ & Total & \\
\hline Animal bedding & & 170 & & 170 & 0 \\
\hline Firewood & 1,900 & 130 & & 2,030 & 0 \\
\hline Open burning & & 300 & & 300 & 0 \\
\hline Mulch & 29,500 & 11,600 & & 41,100 & 0 to -15 \\
\hline Landfill & 3,400 & & 2,000 & 5,400 & -28 \\
\hline Total & 34,800 & 12,200 & 2,000 & 49,000 & \\
\hline Total, tons/year/person & 0.269 & 0.094 & 0.015 & 0.379 & \\
\hline
\end{tabular}

\section{Municipal Solid Waste (MSW) Collection and Disposal}

The garbage pickup and disposal services in Bloomington and Normal are managed by city agencies but performed by the private sector. American Disposal Company owns and operates a transfer station in the metropolitan area and a landfill in Pontiac, Illinois. The tipping fee at the transfer station is $\$ 28 /$ ton. There is no separate wood handling or tipping fee at the transfer station. Brush that is put at curbside by residents of Bloomington is picked up and delivered to Twin City Wood Recycling, where it is ground. In 1996 the total brush handled in this way was about 19,000 cubic yards, or about 5,800 tons. The total garbage picked up in Bloomington in 1996 was about 15,000 tons, of which about 6,000 tons was "bulk waste" (including C/D debris). Grass and leaves picked up in Bloomington are delivered to a farmer who applies the material to his land.

The situation is much the same in the city of Normal, except that the grinding of brush is done by the city Streets Department. The seven months of April through October each 
generate about 2,400 cubic yards of brush, while the five months of November through March each generate an average of about 1,200 cubic yards of brush in Normal. The annual total is about 23,000 cubic yards, or about 7,000 tons of brush. The resulting mulch is made available to the public, and it all gets used.

The manager at American Disposal Company looked up his data on total solid waste delivered from Bloomington-Normal and reported about 34,000 tons/year for 1996. Based on national average data, this figure seems low by a factor of three or four. It is equivalent to only 0.26 tons of MSW/person/year. Based on all the information provided by various parties interviewed, I guesstimate that the MSW going to the landfill contains about $10 \%$ wood, which is equivalent to about 3,400 tons/year based on the data reported, but may be over 10,000 tons/year if my suspicion about the MSW data is correct.

\section{MSW Wood (Primarily Tree and Yard Wastes)}

Twin City Wood Recycling charges tipping fees of $\$ 3.90 /$ cubic yard for brush and pallet wood wastes, and $\$ 4.65 /$ cubic yard for C/D wood waste (equivalent to about $\$ 13 /$ ton and $\$ 15 /$ ton, respectively). The manager's estimates of the annual quantities of wood wastes being processed by Twin City Wood Recycling are about 30,000 cubic yards (about 9,000 tons) of brush and about 35,800 cubic yards (about 11,000 tons) of pallet wood waste. All of this material is ground to mulch and wood chips. The company has not been able to sell these products as fast as they are accumulating, so there is a growing stockpile. A state agency provided a grant for the wood grinder. Twin City provides bins and pickup service to several large companies that produce pallet wood wastes. As described above, the city of Bloomington residential brush pickup supplies about 5,800 tons/year of brush to Twin Cities Wood Recycling, which is ground to mulch. The city of Normal grinds its own brush, an estimated 7,000 tons/year.

The Bloomington-Normal Yellow Pages list 24 tree service companies. I spoke to 19 of these companies, and found that nine of the 24 do not do tree removals or are no longer at the number listed. About eight tree service companies are local and provide tree removal services. Another seven are in small towns in the region, and some of these may do some business in Bloomington-Normal. My estimate is that the local tree service companies average about 500-1,000 tons/year each; my estimate for the total wood waste generated by tree service companies in Bloomington-Normal is 8,000 tons/year, of which about 1,000 tons/year become firewood and 7,000 tons/year become mulch.

The Bloomington Parks and Recreation Department operates two forestry crews, each with a bucket truck and a brush chipper. They stockpile wood mulch in a park; supply exceeds demand in most years. They give away most of the large wood pieces for firewood; the rest are ground by contractors who have grinders that can handle large logs. The three municipal golf courses use mulch, but there is usually more mulch available than they can use. I estimate that the Parks and Recreation Department generates about 300 tons/year of firewood and 2,700 tons/year of mulch.

Illinois State University and Illinois Wesleyan University grounds crews generate about 1,000 tons/year of mulch on each campus, which is reused on campus for landscaping. Small amounts of firewood are recovered, and small amounts of lumber scraps from the drama schools, etc., are hauled to the transfer station. Large tree removals are contracted out to Flynn Tree Service (affiliated with Twin City Wood Recycling) and the wood goes to Twin City Wood Recycling. Illinois Wesleyan University buys some mulch from Twin City Wood Recycling. 
Illinois Power Company employs about seven Asplundh crews (up to nine at times) in the Bloomington-Normal area, trimming trees along their power line rights-of-way. Big pieces of wood are given away as firewood, and mulch is also given away. To estimate the annual quantity, we assumed each crew generates two truckloads per week with 11 cubic yards per truckload. The resulting estimate is about 8,000 cubic yards/year, or about 2,400 tons/year, of which 400 tons/year are assumed to be firewood and the rest mulch.

Table 7-2 summarizes the estimated resources of MSW wood in the Bloomington-Normal area. The total estimate, 34,800 tons/year (of which 3,400 tons/year enter the landfill), is equivalent to 0.269 tons/year/person based on the metropolitan area population of 129,180 . This is above the weighted average of 0.209 tons/year/person of MSW wood for the 30 metropolitan areas, which range from 0.134 to 0.538 tons/year/person.

\section{Table 7-2 \\ Resource Estimate for MSW Wood in Bloomington-Normal, Illinois Tons/year}

\begin{tabular}{|c|c|c|c|c|}
\hline & Mulch & Firewood & Landfill & Total \\
\hline Hauled with trash & & & 3,400 & 3,400 \\
\hline Municipal yard waste recycl. & 18,700 & 300 & & 19,000 \\
\hline Universities & 1,800 & 200 & & 2,000 \\
\hline Utility tree trimming & 2,000 & 400 & & 2,400 \\
\hline Private tree service co's & 7,000 & 1,000 & & 8,000 \\
\hline Total & 29,500 & 1,900 & 3,400 & 34,800 \\
\hline
\end{tabular}

\section{Industrial Wood Wastes}

As discussed above, Twin City Wood Recycling grinds about 11,000 tons/year of pallet wood waste into mulch, and is only partially successful in marketing this material. This represents most of the industrial wood waste in the Bloomington-Normal area. The Bloomington-Normal Yellow Pages list three local companies under Pallets and Skids (one of which is no longer in business), one company under Trusses-Construction, eight companies under Lumber-Retail, and four companies under Furniture Designers and Custom Builders (woodworking companies). Kirk Wood Products, Inc. is primarily a manufacturer of new pallets, an operation that generates very little wood waste. Kirk also handles some scrap pallets, about a semi-load per week, which they break down for reusable boards. Scrap wood, about 300 tons/year, is burned (with a permit) in a rural area. The other pallet company is located in the town of Forrest, and strictly manufactures new pallets. The amount of wood waste is insignificant, and is all burned.

The company listed under Trusses-Construction is a company that primarily makes custommade homes, wall panels, roof trusses, etc., for shipment and assembly throughout a wide geographic area (about a 200-mile radius). This business generates only about 500 tons of wood waste per year, which goes to Twin City Wood Recycling.

Three of the eight retail lumber companies provided useful information. They generate from less than one ton/year to about 100 tons/year (Hundman Lumber) of wood wastes each. Nearly all of this is small pieces and sawdust, which can be used as firewood, animal bedding, or mulch. My total estimate for the nine lumber companies in the Bloomington-Normal area is about 300 tons/year of wood waste, assumed to be split equally among firewood, animal bedding, and mulch. 
Two of the four woodworking companies turned out to be not in the local metropolitan area. The other two companies both produce very small amounts of sawdust, small chips, and small pieces, which are given away as animal bedding, floor sweep material, and fuel for wood burning stoves. The total amount is, at most, 100 tons/year.

Table 7-3 summarizes the estimated resources of industrial wood wastes in the Bloomington-Normal area. The total estimate of 12,200 tons/year is equivalent to 0.094 tons/year/person based on the metropolitan area population of 129,180. This is above the weighted average of 0.048 tons/year/person of industrial wood waste for the 30 metropolitan areas surveyed; the range is from 0.001 to 0.488 tons/year/person.

Table 7-3

\section{Resource Estimate for Industrial Wood Wastes in Bloomington-Normal, Illinois Tons/year}

\begin{tabular}{|c|c|c|c|c|c|}
\hline & Firewood & Mulch & $\underset{\text { Beddin }}{\text { Animal }}$ & Burned & Total \\
\hline Pallet companies & & 11,000 & & 300 & 11,300 \\
\hline Truss companies & & 500 & & & 500 \\
\hline Lumber companies & 100 & 100 & 100 & & 300 \\
\hline Woodworking co's & 30 & & 70 & & 100 \\
\hline Total & 130 & 11,600 & 170 & 300 & 12,200 \\
\hline
\end{tabular}

\section{Construction/Demolition Wood Wastes}

The Bloomington-Normal Yellow Pages list three companies under Demolition Contractors and no companies under Land Clearing \& Leveling. I called the three demolition companies and was successful in talking to two of them. However, the only information they were able to provide was that they believe most of the material they take to the landfill contains very little wood, and is generally dirt, concrete, etc.

Based on information provided by personnel at the Bloomington Public Service Department and American Disposal Company I believe it is reasonable to estimate a total of about 2,000 tons/year for C/D wood wastes in the Bloomington-Normal area, all of which remain mixed with other construction materials and are buried in the landfill. The estimated total of 2,000 tons/year is equivalent to 0.015 tons/year/person based on the Bloomington-Normal metropolitan area population of 129,180 . This is well below the weighted average of 0.076 tons/year/person of C/D wood for the 30 metropolitan areas surveyed; in fact, it is at the bottom of the range ( 0.015 to 0.250 tons/year/person) of per capita estimates for C/D wood in the study. 


\section{Supply Curve}

Figure 7-1 shows the supply curve for urban wood wastes in the Bloomington-Normal area. Table 7-4 shows the data and assumptions used to produce the supply curve.

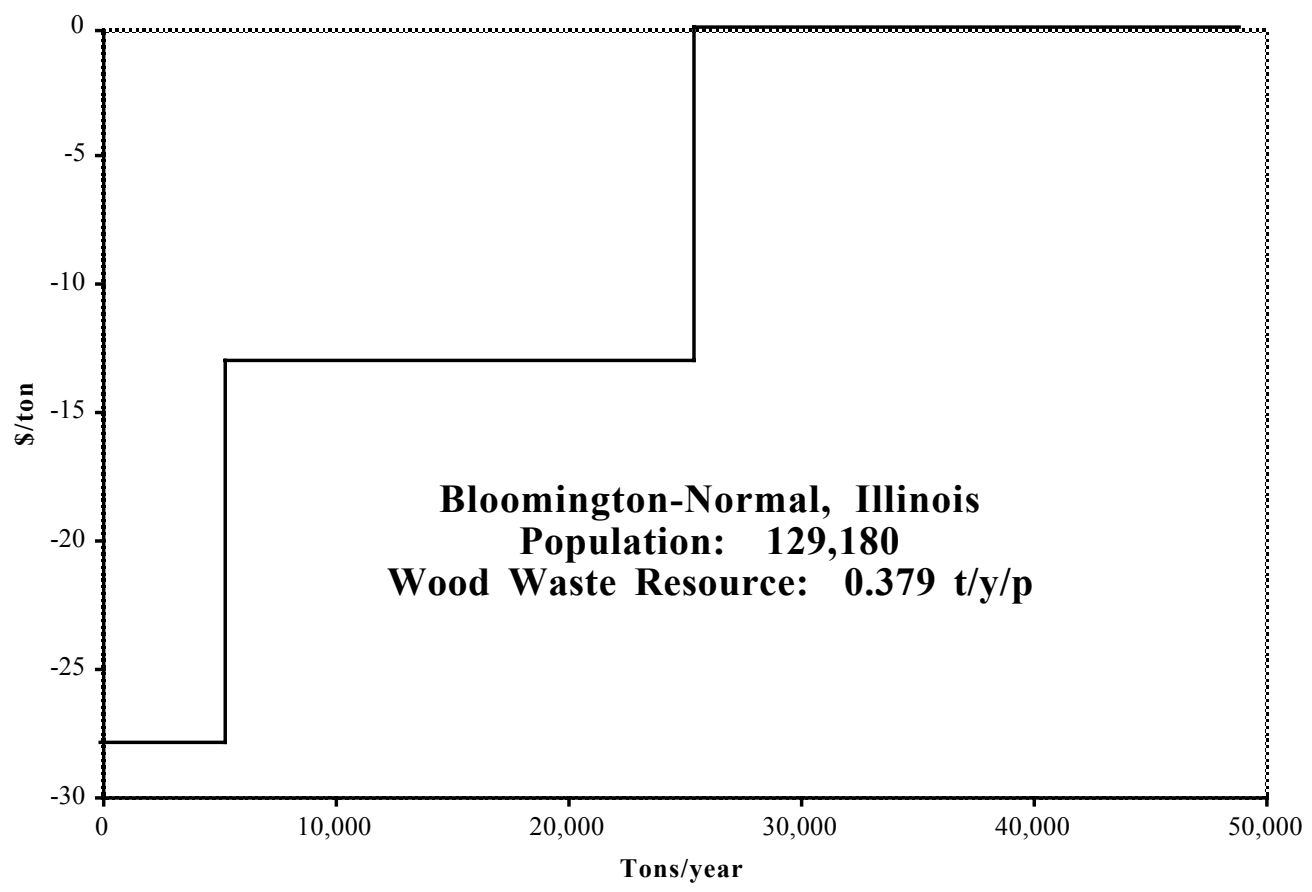

Figure 7-1. Supply Curve for Urban Wood Wastes in Bloomington-Normal, Illinois

Table 7-4

Data and Assumptions Used in Supply Curve for Bloomington-Normal

Tons/year Cumulative $\frac{\text { \$/ton }}{5,400}$

5,400

20,000

23,600

$5,400 \frac{\$}{-28}$

25,400

49,000
Assumptions/Comments

Landfilled with MSW and C/D debris

-13 Wood processors - tree wastes, industrial wood Firewood, mulch, animal bedding - given away 
Battle Creek is in Calhoun County in central Michigan, and is the home of Kellogg's, Post, and Ralston Purina cereal manufacturing facilities. Nearby cities include Kalamazoo (20 miles west), Lansing (40 miles northeast), and Jackson (40 miles east). The market for wood wastes around Battle Creek is constrained by the lack of demand for wood from power plants or other large wood-consuming plants in the region. The biomass power plants in Flint and Genesee, Michigan have large wood waste sources (mills) nearby; it would cost too much to transport wood from Battle Creek to these plants.

Table 8-1 summarizes the data collected on urban wood resources in the Battle Creek area. The estimated total urban wood waste resource, 0.308 tons/year/person, is just below the weighted average of 0.333 tons/year/person for the 30 metropolitan areas surveyed; the range for the 30 cities is from 0.156 to 0.829 tons/year/person. A biomass power project in the Battle Creek area could probably obtain 35,000-45,000 tons/year of feedstock at close to zero delivered cost, and produce 2-5 MW of electricity.

Table 8-1

Resource Estimate for Urban Wood Waste in Battle Creek, Michigan

\begin{tabular}{|c|c|c|c|c|c|}
\hline \multirow[b]{2}{*}{ Use or Disposal Method: } & \multicolumn{4}{|c|}{ Tons/Year } & \multirow[b]{2}{*}{$\begin{array}{l}\text { Price, } \\
\text { \$/ton }\end{array}$} \\
\hline & $\begin{array}{l}\text { MSW } \\
\text { Wood }\end{array}$ & $\begin{array}{l}\text { Industr. } \\
\text { Wood }\end{array}$ & $\begin{array}{c}\text { C/D } \\
\text { Wood }\end{array}$ & Total & \\
\hline Firewood & 2,700 & 240 & & 2,940 & 0 \\
\hline Animal bedding & & 2,100 & & 2,100 & -9 to 0 \\
\hline Mulch & 19,000 & 8,800 & & 27,800 & -9 to 0 \\
\hline Colored chips & & 2,000 & & 2,000 & -9 \\
\hline Landfill & 5,000 & & 2,000 & 7,000 & -31 to -42 \\
\hline Total (rounded) & 26,700 & 13,140 & 2,000 & 41,840 & \\
\hline Total, tons/year/person & 0.196 & 0.097 & 0.015 & 0.308 & \\
\hline
\end{tabular}

\section{Municipal Solid Waste (MSW) Collection and Disposal}

Waste Management of Southwest Michigan, Inc. picks up all the residential trash in Battle Creek and takes it to a Waste Management transfer station, where the trash is compacted and loaded into transport trucks that take it to a Waste Management landfill in Three Rivers, Michigan (south of Kalamazoo). The company also picks up brush, which must be bundled in less than four-foot lengths and less than 50-pound bundles. There is no separation or grinding of wood wastes; the bundles of brush go into the trash trucks and to the landfill. Waste Management does not let people bring trash to the transfer station or landfill, so there is no tipping fee per se -- just a monthly trash pickup charge.

BFI has a landfill in Marshall (10 miles east of Battle Creek) that charges tipping fees of $\$ 9.28$ /cubic yard for regular garbage and $\$ 12.83 /$ cubic yard for $\mathrm{C} / \mathrm{D}$ waste. For loads of wood, these tipping fees are equivalent to about $\$ 31 /$ ton and $\$ 42 /$ ton, respectively. BFI collects yard wastes separately and hauls them to a separate composting site. Lacking any specific data, I estimate that the amount of MSW generated in the Battle Creek metropolitan area is 0.8 ton/person/year (the EPA national figure), or about 109,000 tons/year. My estimate of the amount of wood waste going to landfills with the MSW is about $5 \%$, or about 5,000 tons/year. 


\section{MSW Wood (Primarily Tree and Yard Wastes)}

The Battle Creek Street \& Park Maintenance Department uses one three-man crew to take care of tree trimming and removals for all city rights-of-way and parks. Wood up to six inches in diameter is chipped; larger pieces are given to people who cut them for firewood. There were two major storms in 1997 (one in early spring and one in the fall) that created an unusually large amount of wood waste. The current stockpile of about 28,000 cubic yards of brush and debris is unusually large. In an average year, the department removes about 100-150 trees and trims about 1000, generating 10,000-15,000 cubic yards of wood wastes. I estimate about 500 tons/year go to firewood and 4,000 tons/year go to mulch.

Akers Wood Products Inc. is a wood processing company that that accepts both tree wastes and industrial wood waste. The owner's estimate of his total throughput of wood was about 16,000 tons/year. I estimate that about $20 \%$ of this is tree wastes, or about 3,200 tons/year. Akers receives about five 40-cubic yard loads per day of mostly industrial wood wastes from haulers such as BFI and Waste Management, Inc. He tries to recycle as many reusable pieces of wood as possible, but most of the wood goes through a large tub grinder. The tipping fee is currently $\$ 2.75 /$ cubic yard, which is about $\$ 9 /$ ton. The primary products sold are mulch, bark, and colored landscaping chips for about $\$ 8 /$ cubic yard.

The Battle Creek Yellow Pages list 15 tree service companies, of which 12 were actually local companies and six provided some information. One company owner said he takes his wood to Akers Wood Products Inc. The others grind their own wood and distribute it as mulch and firewood. I estimate that the tree service companies generate about 2,000 tons/year of firewood and 10,000 tons/year of mulch.

Consumers Energy contracts to Asplundh and Townsend for tree trimming and removal work. There are about three crews operating in the Battle Creek area, although there have been as many as ten crews. I estimate that the utility tree trimming crews generate about 200 tons/year of firewood and 1,800 tons/year of mulch.

Table 8-2 summarizes the estimated resources of MSW wood in the Battle Creek area. The total estimate, 26,700 tons/year (of which 5,000 tons/year enter the landfill), is equivalent to 0.196 tons/year/person based on the metropolitan area population of 135,982 . This is just below the weighted average of 0.209 tons/year/person of MSW wood for the 30 metropolitan areas, which range from 0.134 to 0.538 tons/year/person.

Table 8-2

Resource Estimate for MSW Wood in Battle Creek, Michigan Tons/year

\begin{tabular}{|c|c|c|c|c|}
\hline & Mulch & Firewood & Landfill & Total \\
\hline Hauled with trash & & & 5,000 & 5,000 \\
\hline Municipal yard waste recycl. & 7,200 & 500 & & 7,700 \\
\hline Utility tree trimming & 1,800 & 200 & & 2,000 \\
\hline Private tree service co's & 10,000 & 2,000 & & 12,000 \\
\hline Total & 19,000 & 2,700 & 5,000 & 26,700 \\
\hline
\end{tabular}

\section{Industrial Wood Wastes}

As discussed above, Akers Wood Products Inc. grinds about 12,800 tons/year of pallet wood waste into mulch, animal bedding, and colored landscaping chips. The Battle Creek 
Yellow Pages list four other local companies (besides Akers) under Pallets and Skids, no companies under Trusses-Construction, nine companies under Lumber-Retail, and four companies under Furniture Designers and Custom Builders or Cabinet Makers (woodworking companies). The pallet companies besides Akers generate about 200 tons/year, giving a total estimate of 13,000 tons/year for pallet wastes. Of this, I assumed that 200 tons/year go to firewood, and that Akers sells 8,800 tons/year of mulch, 2,000 tons/year of animal bedding, and 2,000 tons/year of colored chips.

Of all the retail lumber companies I talked to, only one (Michigan Woodwork \& Specialties) produces a significant amount of wood wastes, about 100 tons/year. Nearly all of this is sawdust and shavings that go to farmers for animal bedding. The other lumber companies produce very small amounts of scraps that are given away, either to crafts people or as firewood. The same is true for the woodworking companies I talked to. Some amount of wood from these companies ends up in the trash and is assumed to be included in the 5,000 tons/year of MSW wood hauled to landfills.

Table 8-3 summarizes the estimated resources of industrial wood wastes in the Battle Creek metropolitan area. The total estimate of 13,140 tons/year is equivalent to 0.097 tons/year/person based on the metropolitan area population of 135,982. This is above the weighted average of 0.048 tons/year/person of industrial wood waste for the 30 metropolitan areas surveyed; the range is from 0.001 to 0.488 tons/year/person.

Table 8-3

Resource Estimate for Industrial Wood Wastes in Battle Creek, Michigan Tons/year

\begin{tabular}{|c|c|c|c|c|c|}
\hline \multirow{4}{*}{$\begin{array}{l}\text { Pallet companies } \\
\text { Lumber companies } \\
\text { Woodworking co's }\end{array}$} & Firewood & Mulch & $\begin{array}{l}\text { Animal } \\
\text { Beddin }\end{array}$ & $\begin{array}{l}\text { Colored } \\
\text { Chips }\end{array}$ & Total \\
\hline & 200 & 8,800 & 2,000 & 2,000 & 13,000 \\
\hline & & & 100 & & 100 \\
\hline & 40 & & & & 40 \\
\hline Total & 240 & 8,800 & 2,100 & 2,000 & 13,140 \\
\hline
\end{tabular}

\section{Construction/Demolition Wood Wastes}

The Battle Creek Yellow Pages list three local companies under Demolition Contractors and no companies under Land Clearing \& Leveling. I called the three demolition companies and was successful in talking to one of them. C/D material is taken to the BFI landfill; I did not get quantitative estimates. On land clearing jobs, this contractor hires a tree service company to come in and remove trees. I assumed that any such tree wastes were counted in the MSW wood waste category.

Based on information from other similar-sized cities I believe it is reasonable to estimate a total of about 2,000 tons/year for C/D wood wastes in the Battle Creek area, all of which remains mixed with other construction materials and is buried in the landfill. The estimated total of 2,000 tons/year is equivalent to 0.015 tons/year/person based on the Battle Creek metropolitan area population of 135,982. This is well below the weighted average of 0.076 tons/year/person of C/D wood for the 30 metropolitan areas surveyed; in fact, it is at the bottom of the range ( 0.015 to 0.250 tons/year/person) of per capita estimates for C/D wood in the study. 


\section{Supply Curve}

Figure 8-1 shows the supply curve for urban wood wastes in the Battle Creek area. Table 8-4 shows the data and assumptions used to produce the supply curve.

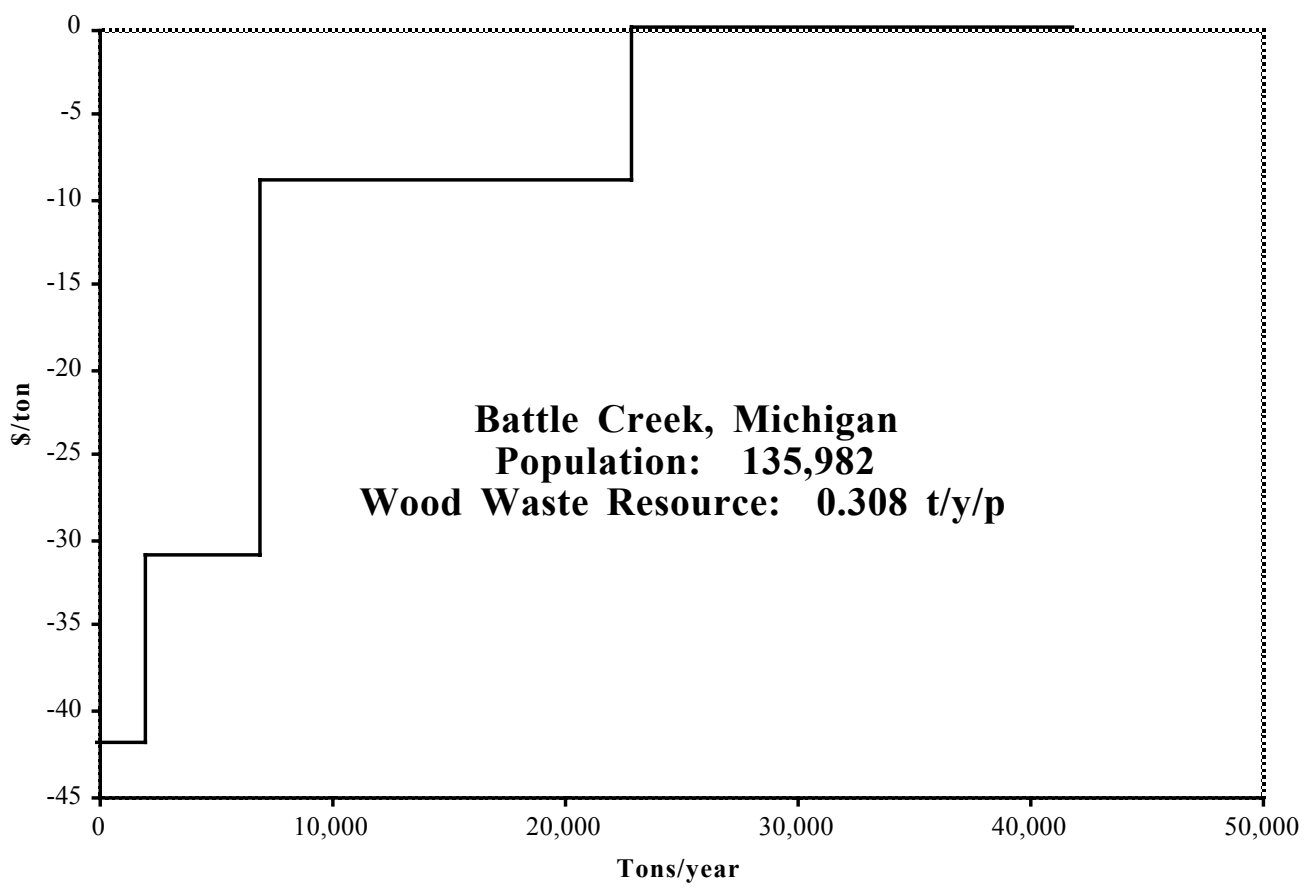

Figure 8-1. Supply Curve for Urban Wood Wastes in Battle Creek, Michigan

\section{Table 8-4}

Data and Assumptions Used in Supply Curve for Battle Creek

Tons/year Cumulative $\$$ /ton

2,000

5,000

16,000

18,840
2,000

7,000

23,000

41,840
Assumptions/Comments

Landfilled with $\mathrm{C} / \mathrm{D}$ debris

-31 Landfilled with MSW

-9 Wood processor - tree wastes, industrial wood

0 Firewood, mulch, animal bedding - given away 
Mansfield is in an agricultural area about halfway between Cleveland and Columbus. For purposes of data collection I assumed that the Mansfield metropolitan area includes the city of Ashland (about 10 miles northeast) and 16 towns or villages in Richland County and Ashland County. The market for wood wastes around Mansfield is constrained by the lack of demand for wood from power plants or other large wood-consuming plants.

Table 9-1 summarizes the data collected on urban wood resources in the Mansfield area. The estimated total urban wood waste resource, 0.291 tons/year/person, is below the weighted average of 0.333 tons/year/person for the 30 metropolitan areas surveyed; the range for the 30 cities is from 0.156 to 0.829 tons/year/person. A biomass power project in the Mansfield area could probably obtain 30,000-40,000 tons/year of feedstock at close to zero delivered cost, and produce 2-4 MW of electricity.

Table 9-1

Resource Estimate for Urban Wood Waste in Mansfield, Ohio

\begin{tabular}{|c|c|c|c|c|c|}
\hline \multirow[b]{2}{*}{ Use or Disposal Method: } & \multicolumn{4}{|c|}{ Tons/Year } & \multirow[b]{2}{*}{$\begin{array}{c}\text { Price, } \\
\text { \$/ton }\end{array}$} \\
\hline & $\begin{array}{l}\text { MSW } \\
\text { Wood }\end{array}$ & $\begin{array}{l}\text { Industr. } \\
\text { Wood }\end{array}$ & $\begin{array}{c}\text { C/D } \\
\text { Wood }\end{array}$ & Total & \\
\hline Firewood & 1,200 & 620 & & 1,820 & 0 \\
\hline Animal bedding & & 2,930 & & 2,930 & 0 to -5 \\
\hline Mulch & 10,800 & 700 & & 11,500 & 0 to -5 \\
\hline Colored chips & & 10,500 & & 10,500 & -5 \\
\hline Landfill & 8,000 & & 2,000 & 10,000 & -23 \\
\hline Total (rounded) & 20,000 & 14,750 & 2,000 & 36,750 & \\
\hline Total, tons/year/person & 0.159 & 0.117 & 0.016 & 0.291 & \\
\hline
\end{tabular}

\section{Municipal Solid Waste (MSW) Collection and Disposal}

Mansfield provides trash pickup to residential customers. Private haulers handle the small towns and rural areas. All of the MSW in Richland County goes via a transfer station to the just-opened Richland County Landfill, which are owned and operated by Superior Services. There is no wood separation or grinding at the transfer station or landfill. The total amount of MSW disposed of in 1996 was 110,000 tons in Richland County and 47,000 tons in Ashland County. The combined total of 157,000 tons/year for the two counties is equivalent to 1.24 tons/year/person, based on the Mansfield metropolitan area population of 126,137. My estimate of the amount of wood entering the landfills with the MSW is about $5 \%$ of the total, or about 8,000 tons/year.

The tipping fees charged by Superior Services at the transfer station and landfill depend on the type and size of vehicle. They are based on a "per cubic yard" amount, but there is no flat rate per cubic yard or per ton. A full-sized pickup truck with material piled to the top of the cab is charged $\$ 28$. A dump truck starts at $\$ 45$. Assuming a pickup truck holds about 4 cubic yards of material, the tipping fee for small loads is about $\$ 7 /$ cubic yard. Assuming wood chips or debris have a specific volume of about 3.3 cubic yards/ton, this tipping fee is roughly equivalent to $\$ 23 /$ ton of wood wastes. 


\section{MSW Wood (Primarily Tree and Yard Wastes)}

The Mansfield Yellow Pages list 15 local tree service companies. Two of these are fairly large operations, generating a total of about 3,000 tons/year. One of these, Dolce's Tree Service, has a tub grinder and provides grinding services for most of the other tree service companies, and sells mulch. Small amounts of firewood are sold for about \$85-90/cord, but most firewood is given away or used. I estimate that tree service companies in the Mansfield area generate about 1,000 tons/year of firewood and 9,000 tons/year of mulch. Ohio Edison Company did not return my calls; I estimate that the utility's tree trimming crews generate about 200 tons/year of firewood and 1,800 tons/year of mulch.

Table 9-2 summarizes the estimated resources of MSW wood in the Mansfield area. The total estimate, 20,000 tons/year (of which 8,000 tons/year enter the landfill), is equivalent to 0.159 tons/year/person based on the metropolitan area population of 126,137 . This is below the weighted average of 0.209 tons/year/person of MSW wood for the 30 metropolitan areas, which range from 0.134 to 0.538 tons/year/person.

\section{Table 9-2 \\ Resource Estimate for MSW Wood in Mansfield, Ohio Tons/year}

\begin{tabular}{|c|c|c|c|c|}
\hline & Mulch & Firewood & Landfill & Total \\
\hline Hauled with trash & & & 8,000 & 8,000 \\
\hline Utility tree trimming & 1,800 & 200 & & 2,000 \\
\hline Private tree service co's & 9,000 & 1,000 & & 10,000 \\
\hline Total & 10,800 & 1,200 & 8,000 & 20,000 \\
\hline
\end{tabular}

\section{Industrial Wood Wastes}

The Mansfield Yellow Pages list 11 local companies under Pallets and Skids, no companies under Trusses-Construction, four companies under Lumber-Wholesale, 14 companies under Lumber-Retail, and 10 companies under Cabinet Makers (woodworking companies). Kaple Lumber Company in Shiloh has the largest wood grinding operation in the Mansfield area, receiving mostly pallet wastes. They charge a tipping fee of $\$ 1.50 /$ cubic yard (about $\$ 5 /$ ton) and produce about 9,000 tons/year of landscaping chips, which they color red, brown, black, gold, etc., and sell to brokers in Medina, Toledo, and Ft. Wayne.

BFI has a wood grinding and composting operation at its recycling center near Mansfield. I was unable to get any information from BFI. One of the mulch brokers that buys colored chips from Kaple Lumber also mentioned BFI as a supplier, although much smaller. I estimate BFI converts about 1,000 tons/year of pallet wastes to colored chips. American Pallet Recycling sells significant amounts of colored chips, mulch, and sawdust, and gives away firewood. Most of its pallet customers are manufacturing companies around Ashland. I estimate American Pallet Recycling produces 500 tons/year of colored chips, 400 tons/year of mulch, 70 tons/year of firewood, and 30 tons/year of animal bedding.

The other seven pallet companies primarily make new pallets and generate small amounts of wood waste, ranging from about 10 tons/year to about 100 tons/year each. I estimate that the total amount of wood waste generated by these companies is 300 tons/year, and have assumed that all of this goes to mulch (although one company mentioned a "burn pile"). 
My estimated total for the four wholesale companies and 14 retail lumber companies in the Mansfield area is 500 tons/year of firewood and 500 tons/year of animal bedding. Cass Woodworking Shop in Galion is a relatively large operation (about 50 employees) that mass produces picture frames and does custom cabinet work. They give about 2,400 tons/year of sawdust to farmers in the area, and dispose of about 800 tons/year of wood scraps. I have assumed that the wood scraps are already counted under Kaple or BFI. All of the other woodworking shops in the Mansfield area are small operations that produce about 10 tons/year of wood wastes each. My total estimate for the nine companies in this category is 100 tons/year, of which about half goes to Kaple or BFI (and thus is already counted). The other half becomes firewood or is burned in the open.

Table 9-3 summarizes the estimated resources of industrial wood wastes in the Mansfield area. The total estimate of 14,750 tons/year is equivalent to 0.117 tons/year/person based on the metropolitan area population of 126,137 . This is above the weighted average of 0.048 tons/year/person of industrial wood waste for the 30 metropolitan areas surveyed; the range is from 0.001 to 0.488 tons/year/person.

\section{Table 9-3 \\ Resource Estimate for Industrial Wood Wastes in Mansfield, Ohio Tons/year}

\begin{tabular}{|c|c|c|c|c|c|}
\hline & Firewood & Mulch & $\underset{\text { Beddin }}{\text { Animal }}$ & $\begin{array}{c}\text { Colored } \\
\text { Chips }\end{array}$ & Total \\
\hline Pallet companies & 70 & 700 & 30 & 10,500 & 11,300 \\
\hline Lumber companies & 500 & & 500 & & 1,000 \\
\hline Woodworking co's & 50 & & 2,400 & & 2,450 \\
\hline Total & 620 & 700 & 2,930 & 10,500 & 14,750 \\
\hline
\end{tabular}

\section{Construction/Demolition Wood Wastes}

The Mansfield Yellow Pages list three local companies under Demolition Contractors and no companies under Land Clearing \& Leveling. I called the three demolition companies and was successful in talking to one of them. C/D material is taken to the landfill; I did not get quantitative estimates. On land clearing jobs, trees get cut up and used for firewood, stumps get dumped at the demolition company's site, and mulch is incorporated into the soil at the construction site.

Based on information from other similar-sized cities I believe it is reasonable to estimate a total of about 2,000 tons/year for C/D wood wastes in the Mansfield area, all of which remains mixed with other construction materials and is buried in the landfill. The estimated total of 2,000 tons/year is equivalent to 0.016 tons/year/person based on the Mansfield metropolitan area population of 126,137. This is well below the weighted average of 0.076 tons/year/person of C/D wood for the 30 metropolitan areas surveyed; in fact, it is near the bottom of the range ( 0.015 to 0.250 tons/year/person) of per capita estimates for $\mathrm{C} / \mathrm{D}$ wood in the study. 


\section{Supply Curve}

Figure 9-1 shows the supply curve for urban wood wastes in the Mansfield area. Table 94 shows the data and assumptions used to produce the supply curve.

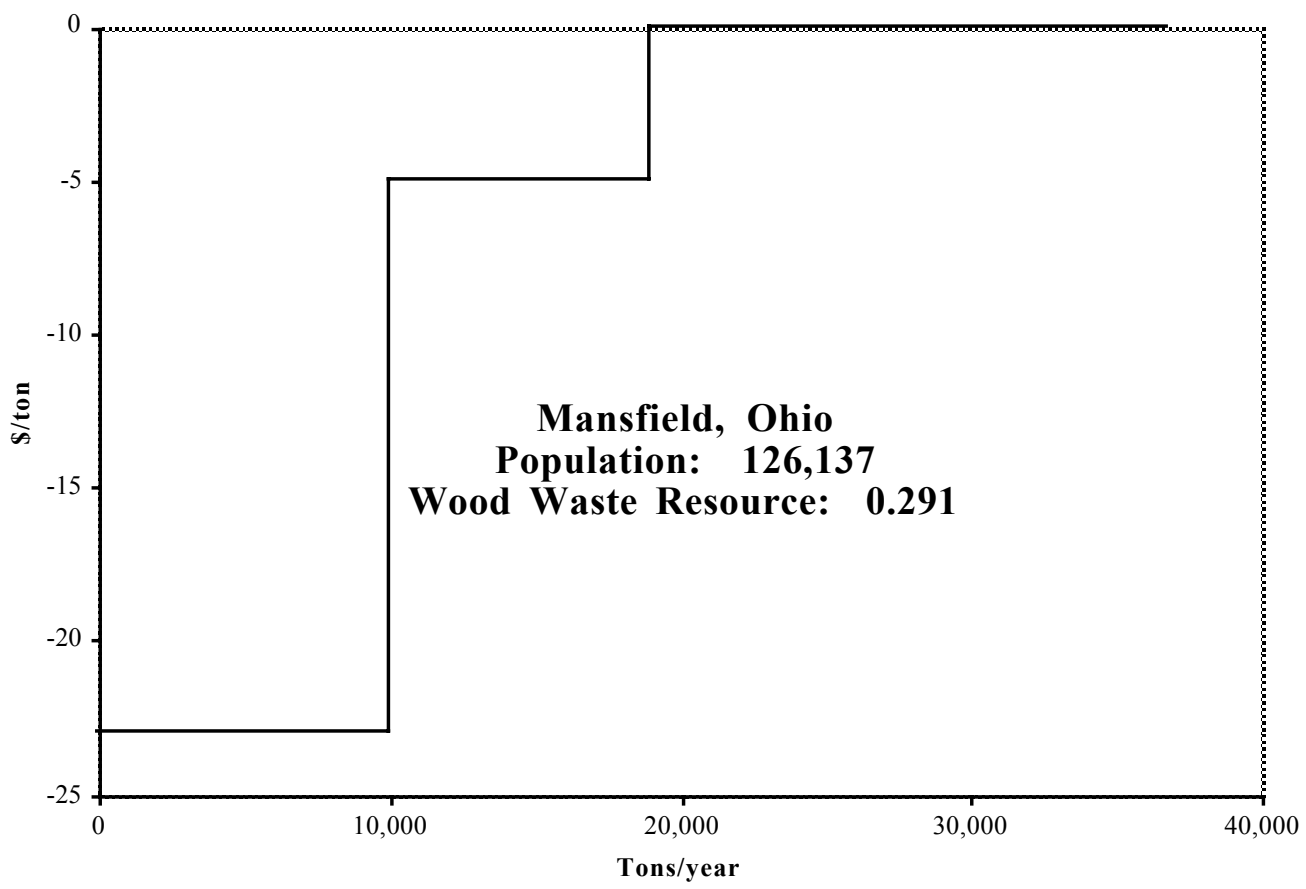

Figure 9-1. Supply Curve for Urban Wood Wastes in Mansfield, Ohio

\section{Table 9-4}

Data and Assumptions Used in Supply Curve for Mansfield

Tons/year Cumulative $\frac{\text { \$/ton }}{10,000}$

$10,000 \frac{10,000}{-23}$

Assumptions/Comments

$9,000 \quad 19,000 \quad-5 \quad$ Wood processor - industrial wood

$17,750 \quad 36,750 \quad 0 \quad$ Firewood, mulch, animal bedding - given away 
Elmira is south of the Finger Lakes in western New York, just a few miles north of the Pennsylvania border, about 15 miles east of Corning and 50 miles west of Binghamton. The region is referred to as the "Southern Tier". Elmira is centrally located in Chemung County, which has a population of about 100,000. Corning is in Steuben County, and I did not include either Corning or Steuben County as part of the Elmira metropolitan area. Small towns and villages that I did include as part of the Elmira metropolitan area are Horseheads, Pine City, Big Flats, Breesport, Chemung, Erin, Lowman, Millport, Pine Valley, Van Etten, and Wellsburg.

Table 10-1 summarizes the data collected on urban wood resources in the Elmira area. The estimated total urban wood waste resource, 0.269 tons/year/person, is below the weighted average of 0.333 tons/year/person for the 30 metropolitan areas surveyed; the range for the 30 cities is from 0.156 to 0.829 tons/year/person. The market for wood wastes around Elmira is constrained by the lack of demand for wood from power plants or other large wood-consuming (such as medium-density fiberboard) plants in the region. New York State Electric \& Gas Company (NYSEG) has a coal-fired power plant about 40 miles north of Elmira (the Greenidge plant in Dresden, New York on Seneca Lake). That plant has been cofiring wood wastes with coal for several years, and currently consumes about 20,000 tons/year of wood, very little of which comes from Elmira. A biomass project developer in the Elmira area could probably secure 8,000-10,000 tons/year of feedstock at close to zero delivered cost (most of it from the Chemung County landfill, which grinds wood and puts it in a C/D landfill cell), and produce 0.5 to $1 \mathrm{MW}$ of electricity.

Table 10-1

Resource Estimate for Urban Wood Waste in Elmira, New York

\begin{tabular}{|c|c|c|c|c|c|}
\hline \multirow[b]{2}{*}{ Use or Disposal Method: } & \multicolumn{4}{|c|}{ Tons/Year } & \multirow[b]{2}{*}{$\begin{array}{c}\text { Price, } \\
\text { \$/ton }\end{array}$} \\
\hline & $\begin{array}{l}\text { MSW } \\
\text { Wood }\end{array}$ & $\begin{array}{l}\text { Industr. } \\
\text { Wood }\end{array}$ & $\begin{array}{c}\text { C/D } \\
\text { Wood }\end{array}$ & Total & \\
\hline Firewood & 2,000 & 2,220 & & 4,220 & 0 \\
\hline Mulch & 8,500 & & & 8,500 & 0 \\
\hline Boiler fuel & & 2,000 & & 2,000 & 0 \\
\hline Landfill & 2,300 & & 8,600 & 10,900 & -50 to -55 \\
\hline Total & 12,800 & 4,220 & 8,600 & 25,620 & \\
\hline Total, tons/year/person & 0.134 & 0.044 & 0.090 & 0.269 & \\
\hline
\end{tabular}

\section{Municipal Solid Waste (MSW) Collection and Disposal}

The City of Elmira provides trash pickup to residential customers in Elmira. Private haulers handle the small towns and rural areas. All of the MSW in Chemung County goes to the Chemung County Landfill -- much of it by way of four county-owned transfer stations, two of which are in Elmira, one in Horseheads, and one in Erin. The landfill itself is located in Lowman, about ten miles east of Elmira and Horseheads. Tipping fees are $\$ 55 /$ ton for MSW and $\$ 50 /$ ton for $\mathrm{C} / \mathrm{D}$ waste. The landfill does not receive much brush, but it does have a grinder and uses some mulch as daily cover, and buries the rest in the C/D cell. Some municipalities, such as Horseheads, grind up brush and distribute it as mulch. The brush collected by Elmira city trucks goes to the Elmira transfer station on Lake Street, which is called the Milling Site and has complete recycling capabilities. 
About 47,000 tons/year of MSW are dumped in the MSW cells at the Chemung County Landfill, and about 13,000 tons/year of C/D waste (including wood that is ground onsite) are placed in the C/D cell. The landfill manager estimates that about $5 \%$ of the MSW may be wood, and that about $2 / 3$ of the material entering the $C / D$ cell is wood. In the tables below, I have counted the former (2,300 tons/year) as MSW wood, and the latter $(8,600$ tons/year) as $\mathrm{C} / \mathrm{D}$ wood.

\section{MSW Wood (Primarily Tree and Yard Wastes)}

As discussed above, Elmira and several other municipalities grind yard waste and recycle it as mulch. I estimate the quantity to be about 2,000 tons/year. Several of the trash hauling companies said that they separate usable wood from some loads. When they get loads of waste wood to haul, including tree removals, they take them to the county landfill at Lowman. The landfill grinds wood and places it in the C/D cell. (Note that I have counted this as C/D wood rather than MSW wood.)

NYSEG provides electric service to the Elmira area. The manager of NYSEG's tree trimming operations said that most of the wood is chipped and left in place as the crews work. In many cases, the terrain is too remote and difficult to allow recovery of the wood in an economical manner. As a result, most of the utility's waste wood from tree trimming cannot be considered a resource. My guesstimate of the amount of wood waste generated by NYSEG in the Elmira area that could be recovered is about 500 tons/year, all mulch.

The Elmira Yellow Pages list 13 local tree service companies. After calling all of them, I determined that nine tree companies actually operate in the Elmira area, and I was able to get quantitative information from two of them. My estimate is that tree service companies in Elmira generate about 8,000 tons/year of wood wastes, about 2,000 tons/year to firewood and 6,000 tons/year to mulch.

Table 10-2 summarizes the estimated resources of MSW wood in the Elmira area. The total estimate, 12,800 tons/year (of which 2,300 tons/year enter the landfill), is equivalent to 0.134 tons/year/person based on the Elmira metropolitan area population of 95,195. This is below the weighted average of 0.209 tons/year/person of MSW wood for the 30 metropolitan areas; in fact, it is at the bottom of the range ( 0.134 to 0.538 tons/year/person) of per capita estimates for MSW wood in the study.

\section{Table 10-2 \\ Resource Estimate for MSW Wood in Elmira, New York Tons/year}

\begin{tabular}{|c|c|c|c|c|}
\hline & Mulch & Firewood & Landfill & Total \\
\hline Hauled with trash & & & 2,300 & 2,300 \\
\hline Municipal yard waste recycl. & 2,000 & & & 2,000 \\
\hline Utility tree trimming & 500 & & & 500 \\
\hline Private tree service co's & 6,000 & 2,000 & & 8,000 \\
\hline Total & 8,500 & 2,000 & 2,300 & 12,800 \\
\hline
\end{tabular}

\section{Industrial Wood Wastes}

The Elmira Yellow Pages list three local companies under Pallets and Skids, no companies under Trusses-Construction, one local company under Lumber-Wholesale, seven companies under Lumber-Retail, and five companies under Cabinet Makers or Furniture 
Manufacturers (woodworking companies). The Pallet Corporation of America in Elmira grinds about 2,000 tons/year of pallet wood waste and sells it to the power company (presumably NYSEG) and to some schools for boiler fuel. When I asked if he got a good price for the wood fuel, he said "no, but it's better than paying to get rid of it."

The Lindley Wood Works in Lindley burns some of its own waste wood, and sells about 1,200 tons/year of wood pieces as firewood. Valley Pallet Corporation in Waverly gives away their waste wood as firewood. They have a bin out by the road, and people pick up the wood on a regular basis. I estimate they give away about 800 tons/year. Thus, the total estimate for pallet wastes in the Elmira area is 4,000 tons/year, of which 2,000 tons/year go to boiler fuel and 2,000 tons/year go to firewood.

The retail lumber companies in the Elmira area all give away their waste wood as firewood. They put pieces of wood in bins for people to take, and some companies also put pallets out by the road for people to take. The total amount is probably about 200 tons/year.

The woodworking companies (cabinet and furniture makers) in the Elmira area are all very small companies. They produce very small amounts of wood scraps that are used by family and friends. My estimate is 20 tons/year.

Table 10-3 summarizes the estimated resources of industrial wood wastes in the Elmira metropolitan area. The total estimate of 4,220 tons/year is equivalent to 0.044 tons/year/person based on the Elmira metropolitan area population of 95,195. This is very close to the weighted average of 0.048 tons/year/person of industrial wood waste for the 30 metropolitan areas surveyed; the range is from 0.001 to 0.488 tons/year/person.

Table 10-3

Resource Estimate for Industrial Wood Wastes in EImira, New York Tons/year

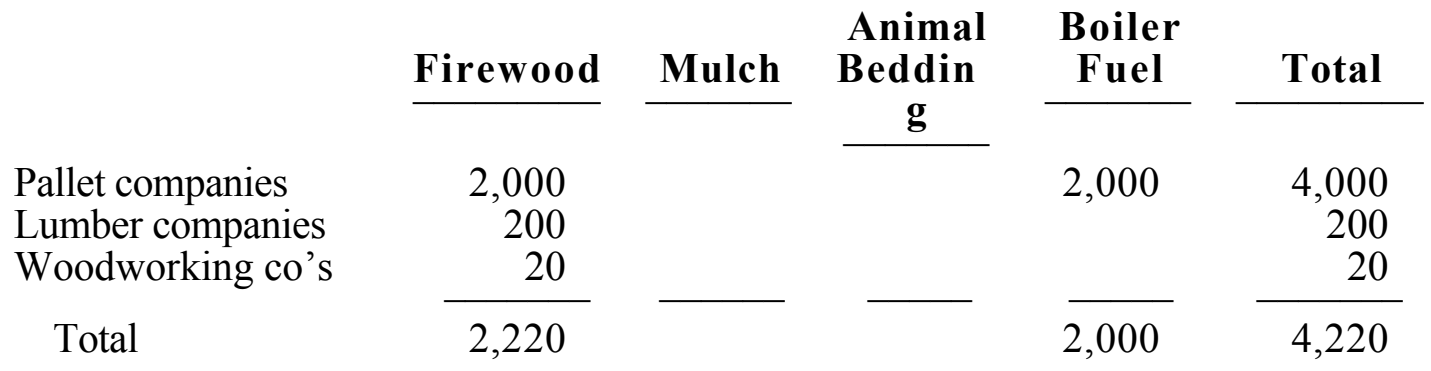

\section{Construction/Demolition Wood Wastes}

The Elmira Yellow Pages list two local companies under Demolition Contractors and no companies under Land Clearing \& Leveling. I called both demolition companies and found that they take all of their C/D material to the county landfill; I did not get quantitative estimates. Based on information from the landfill manager as discussed above, I estimate that 8,600 tons/year of wood waste are ground and dumped in the landfill's C/D cell. The estimated total of 8,600 tons/year is equivalent to 0.090 tons/year/person based on the Elmira metropolitan area population of 95,195. This is above the weighted average of 0.076 tons/year/person of C/D wood for the 30 metropolitan areas surveyed; the range is from 0.015 to 0.250 tons/year/person. 


\section{Supply Curve}

Figure 10-1 shows the supply curve for urban wood wastes in the Elmira area. Table 10-4 shows the data and assumptions used to produce the supply curve.

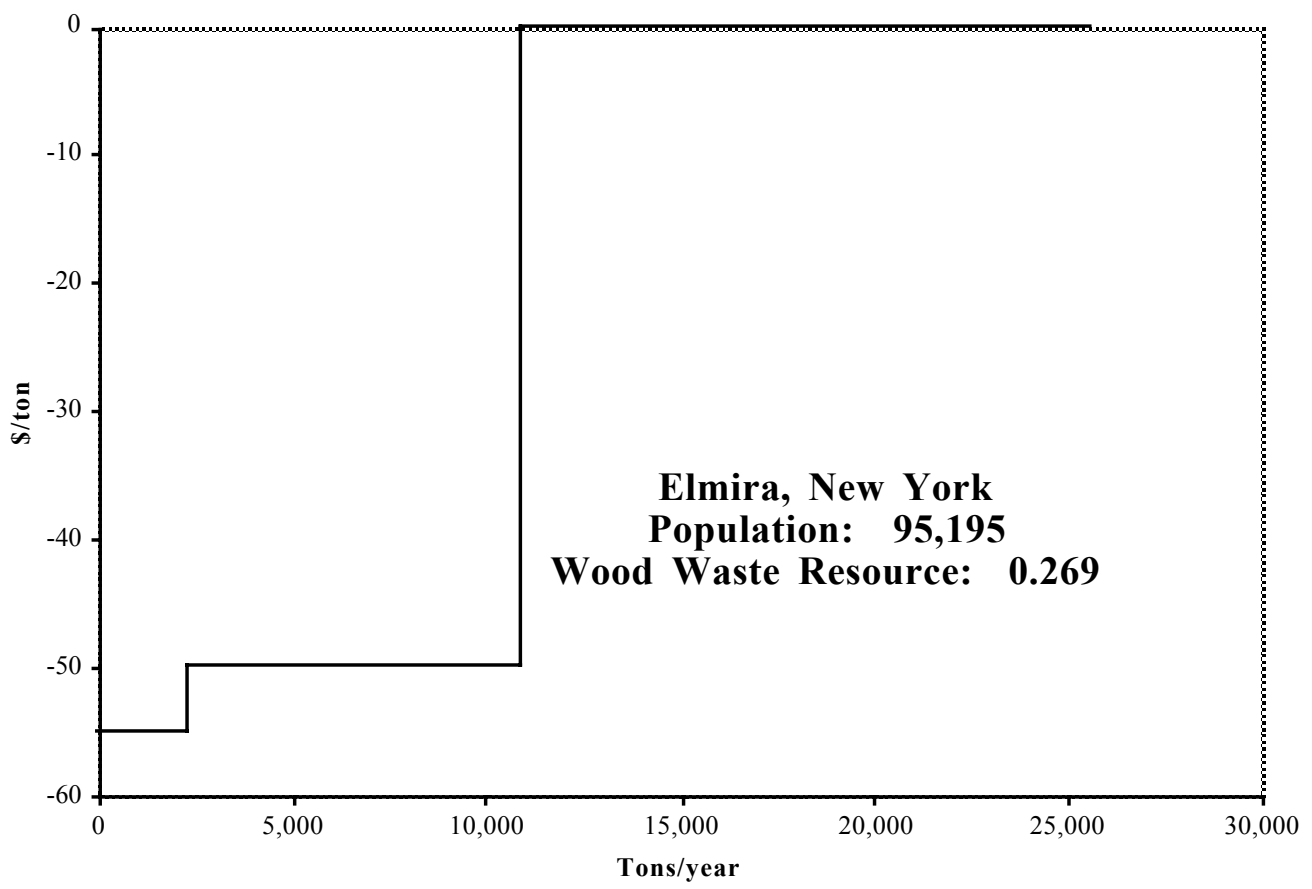

Figure 10-1. Supply Curve for Urban Wood Wastes in Elmira, New York

Table 10-4

Data and Assumptions Used in Supply Curve for Elmira

Tons/year Cumulative \$/ton

2,300

$2,300 \frac{\$}{-55}$

8,600

10,900

$-50$

14,720

25,620

Assumptions/Comments

Landfilled with MSW

Landfilled with $\mathrm{C} / \mathrm{D}$ debris

0 Firewood, mulch, animal bedding - given away 
Boston is one of the ten largest metropolitan areas in the US, with a thriving, diversified economy. The area contains a large number of universities, and major concentrations of high-technology businesses. I obtained data from only a few of the major cities, and was able to obtain only a little information from state agencies. Because of the active market in wood fuel and mulch in the area (as well as the tough competition in the waste management industry), private companies were more than usually cautious about sharing information.

Table 11-1 summarizes the data collected on urban wood resources in the Boston area. The estimated total urban wood waste resource, 0.330 tons/year/person, is very close to the weighted average of 0.333 tons/year/person for the 30 metropolitan areas surveyed; the range for the 30 cities is from 0.156 to 0.829 tons/year/person. Large wood processing companies deliver biomass fuel to power plants in the northern New England states. Some of these wood processors are located in the Boston metropolitan area, and others are in the neighboring states. The 292,400 tons/year going to biomass fuel are enough to generate about 25 MW of electricity. Still, a large proportion of Sacramento's wood waste is informally recycled to mulch or disposed of in landfills and incinerators. A local biomass power project could probably secure 400,000-500,000 tons/year of feedstock at close to zero delivered cost, and produce $28-53 \mathrm{MW}$ of electricity.

Table 11-1

Resource Estimate for Urban Wood Waste in Boston, Massachusetts

\begin{tabular}{|c|c|c|c|c|c|}
\hline \multirow[b]{2}{*}{ Use or Disposal Method: } & \multicolumn{4}{|c|}{ Tons/Year } & \multirow[b]{2}{*}{$\begin{array}{l}\text { Price, } \\
\text { \$/ton }\end{array}$} \\
\hline & $\begin{array}{l}\text { MSW } \\
\text { Wood }\end{array}$ & $\begin{array}{l}\text { Industr. } \\
\text { Wood }\end{array}$ & $\begin{array}{c}\text { C/D } \\
\text { Wood }\end{array}$ & Total & \\
\hline Firelogs and pellets & & & 1,000 & 1,000 & \\
\hline Mulch or firewood & 154,000 & 12,200 & 5,000 & 171,200 & 0 to -45 \\
\hline Biomass fuel & 130,000 & 48,400 & 114,000 & 292,400 & 0 to -45 \\
\hline Combustion or landfill & 78,000 & 400 & 100,000 & 178,400 & -50 to -85 \\
\hline Total (roun & 362,000 & 61,000 & 220,000 & 643,000 & \\
\hline Total, tons/year/person & 0.186 & 0.031 & 0.113 & 0.330 & \\
\hline
\end{tabular}

\section{Municipal Solid Waste (MSW) Collection and Disposal}

Most trash pickup and hauling services in the Boston metropolitan area are provided by private haulers. Only seven Boston-area municipalities have active landfills, all of which are closing by the end of 1998. In the city of Boston itself, Waste Management Inc. and Laidlaw currently have contracts for residential trash pickup routes. The city of Cambridge Sanitation Department picks up residential trash and hauls it to a transfer station in Somerville owned and operated by Waste Management Inc. The tipping fee charged by the WMI transfer station to the city is about $\$ 50-54 /$ ton; to others, the tipping fee is $\$ 85 /$ ton. Waste Management Inc. hauls trash from the transfer station (which receives trash from all over the Boston metro area, not just from Cambridge) to its Turnkey Landfill in Rochester, New Hampshire. At the landfill in New Hampshire (but not at the transfer station in Somerville), Waste Management has a wood grinding and yard waste composting

\footnotetext{
${ }^{1}$ This is the estimated population of the cities and towns covered by the "Yellow Pages for the Boston Area (including Brookline, Cambridge, and Somerville)", which is the area covered in the data collection effort reported here. See the final subsection in this section for more information on the survey area.
} 
operation. Around Boston, Waste Management hauls loads of clean wood, such as pallets and tree wastes, to Kaknes Wood Products and Landscape Supply, Inc. Other haulers in the Boston area take wood to processors in New Hampshire and Maine who produce fuel.

The Massachusetts Solid Waste Management Plan 1997 Update (Draft, July 1997) provided the following statistics for the state as a whole in 1996, in tons/year:

$\begin{array}{lrcr}\text { Total generation } & 11,190,000 & \text { Diversion } & 5,240,000 \\ \text { Exports } & 408,000 & \text { MSW } & 2,340,000 \\ \text { MSW } & 7,160,000 & \text { Residential recycling } & 470,000 \\ \text { Residential } & 3,280,000 & \text { Commercial recycling } & 1,200,000 \\ \text { Commercial } & 3,880,000 & \text { Residential composting } & 440,000 \\ \text { Non-MSW } & 4,030,000 & \text { Commercial composting } & 230,000 \\ \text { C/D } & 3,780,000 & \text { Non-MSW (C/D) } & 2,900,000 \\ \text { Biosolids } & 70,000 & \text { Disposal } & 6,150,000 \\ \text { Other } & 180,000 & \text { Landfill } & 2,820,000 \\ \text { Total management } & 11,390,000 & \text { MSW } & 1,620,000 \\ \text { Imports } & 608,000 & \text { C/D } & 900,000 \\ & & \text { Biosolids } & 70,000 \\ & & \text { Other } & 230,000 \\ & & \text { Combustion } & 3,330,000 \\ & & \text { MSW } & 3,310,000 \\ & & \text { Other } & 20,000\end{array}$

Of the 7.16 million tons of MSW generated in Massachusetts in 1996, about 33\% were recycled, $46 \%$ went to combustion facilities, and $21 \%$ were landfilled. Most of the waste exported from Massachusetts (408,000 tons) went to Waste Management's landfill in New Hampshire from the Boston area. The 2.9 million tons of C\&D debris diverted consisted primarily of asphalt road pavement and concrete. A small portion, by weight, was wood chipped for mulch or for landfill cover. This non-MSW was processed and recycled by 55 C\&D waste processing facilities in the state. There are nine solid waste combustion facilities in Massachusetts, none of which are in the Boston metropolitan area. The number of landfills operating in the state will decrease from 73 in 1997 to 11 in 2000.

The Boston area population $(1,950,855)$ is $32.4 \%$ of the state's population $(6,018,305)$. I estimate that the MSW generation in the Boston area is 0.324 times $7,160,000$, or about $2,320,000$ tons/year. About $67 \%$ of that MSW, or 1,550,000 tons/year, goes to landfills or combustion facilities. Assuming 5\% of that MSW is wood, about 78,000 tons/year of wood wastes from the Boston area enter MSW combustion facilities and landfills.

\section{MSW Wood (Primarily Tree and Yard Wastes)}

Boston has a composting site at the city yard, where yard waste picked up by the trash haulers is composted and given away to the public. Demand for the compost exceeds supply. One crew takes care of city trees on sidewalks and parks in Boston; contractors are hired when needed. A storm on April 1, 1997 produced over 10,000 cubic yards of tree debris within the city limits of Boston, most of which is still piled at the city yard. There is not much demand for mulch or firewood in the city; some mulch is used in city parks, and the rest is hauled away. Wood waste generation from city trees in an average year is about 5,000 cubic yards, or about 1,500 tons/year. Assuming all of the cities and towns in the metropolitan area have per capita tree trimming rates that are similar to the rate in Boston 
itself, I estimate that the total generation of wood from tree trimming and removals on city property in the Boston metropolitan area is about 5,000 tons/year.

BFI hauls trash for municipalities and businesses, usually to combustion facilities that the municipalities designate. BFI does no wood grinding or separation in the Boston area, but uses a company named Lopes in Taunton that grinds wood and stumps as well as concrete. Other trash haulers haul loads of wood to Kaknes Wood Products \& Landscape Supply Inc. in Woburn. Kaknes' price list indicates the following tipping fees: \$9/cubic yard for yard wastes; \$6/cubic yard for pallets or whole tree chips; $\$ 14 /$ cubic yard for stumps or logs over two feet in diameter; and $\$ 10 /$ cubic yard for clean construction wood and fencing. (Very roughly, these tipping fees are equivalent to $\$ 20-45 /$ ton.) Products include a variety of bark mulches (using bark brought in from Maine) for $\$ 22.50$ to $\$ 30.50 /$ yard; hemlock colored chip (using wood brought in from Maine and Vermont) for \$27/yard; and composted wood mulch for $\$ 15 /$ yard. The company accepts grass clippings and other yard waste, and sells compost and "super loam" (screened loam mixed with 10\% compost) for $\$ 17-21 /$ cubic yard. Whatever Kaknes cannot sell in these relatively high value-added forms is sold as biomass fuel, which is typically a break-even product at best. I have used an estimate of 100,000 tons/year for Kaknes Wood Products, and assumed that 20,000 tons/year come from pallets and 80,000 tons/year come from tree wastes and other MSW wood. Of the MSW wood, I have assumed that 60,000 tons/year end up as mulch and 20,000 tons/year end up as biomass fuel. Of the pallet wood, I have assumed that 10,000 tons/year end up as mulch and 10,000 tons/year end up as biomass fuel.

Northern Tree Servicing in Palmer, Massachusetts processes about 13,000 tons/year of tree wastes from the Boston area (about half from land clearing and half from municipal trees). Northern Tree sells most of this wood as biomass fuel to power plants in New Hampshire, Maine, and Fitchburg, Massachusetts. Off-spec material is used as low-grade mulch at new residential developments and other commercial landscaping projects. A small amount goes to sewage treatment plants for blending with biosolids. Northern Tree has wood processing yards in Bellerica, Lowell, Tewksbury, and Malden.

JM Cook Company in Mendon, Massachusetts operates two big wood grinding machines, grinding tree wastes, stumps, and pallets for municipalities, tree service companies, and industrial companies. Scott Paper Company in Maine takes all their wood chips as fuel for its power boiler. The total is probably about 40,000 tons/year, of which maybe 20,000 tons/year come from stumps, 12,000 tons/year come from tree wastes, and 8,000 tons/year come from pallets. JM Cook's trucks haul bark back from Maine, which is ground and sold as bark mulch. The company's wood processing yard in Bellingham charges a tipping fee of about $\$ 185$ for a 30-yard trailer of wood (equivalent to about $\$ 20 /$ ton). They provide pallet waste pick-up service to two pallet companies. About 75 towns (about 1/4 of the towns in Massachusetts) use JM Cook for municipal wood recycling.

New England Recycling in Taunton, Massachusetts has a wood processing yard that grinds stumps and tree wastes (mostly from land clearing), and pallet wastes. At a separate site, New England Recycling runs a C/D waste disposal operation, grinding, picking, and then landfilling the construction and demolition waste. Tipping fees are $\$ 6 /$ cubic yard for stumps, $\$ 3 /$ cubic yard for pallets (both roughly equivalent to $\$ 15-20 /$ ton), and $\$ 15 /$ cubic yard for C/D waste. Stump grindings (about 8,000 tons/year) are stored over winter, ground again in the spring, and sold as mulch. Ground pallet wastes are sold as fuel to the biomass power plant in Fitchburg, Massachusetts; my guess is 10,000 tons/year.

The Boston Area Yellow Pages list 108 tree service companies, 19 with big ads. I called about 30 of these companies and obtained useful information from seven of them. I estimate that about 20 of the tree service companies operate multiple crews and generate an 
average of 2,000 tons/year of wood. About 80 of the other companies operate one crew and average about 1,000 tons/year of wood waste generation. I estimate that tree service companies in the Boston area generate about 60,000 tons/year of biomass fuel, 40,000 tons/year of mulch, and 20,000 tons/year of firewood.

Harvard University has about 3,000 trees on its campuses and five arborists on its staff, who do most of the tree trimming work themselves. The wood is chipped and composted at the Arnold Arboretum across town, and used there. I did not get an estimate of the quantity of wood generated in a typical year; my guess is in the range of 100-500 tons/year. Boston College does its own composting and reuses the compost on campus. Boston University's tree wastes are largely hauled away with the trash. The quantities estimated were very small: 300-500 cubic yards/year of leaves, and 10-20 cubic yards/year of wood (less than 10 tons/year of wood). I estimate that all of the universities and colleges in the Boston area generate about 1,000 tons/year, which go largely to mulch or compost.

The only Boston area electric utility from which I was able to get information about tree trimming was Cambridge Electric Light, whose estimate was about 900 tons/year. I estimated the utility wood generation for the Boston metropolitan area based on the population ratio to Cambridge: 20,000 tons/year.

Table 11-2 summarizes the estimated resources of MSW wood in the Boston area. The total estimate, 362,000 tons/year (of which 78,000 tons/year enter combustion plants or landfills), is equivalent to 0.186 tons/year/person based on the area population of $1,950,855$. This is below the weighted average of 0.209 tons/year/person of MSW wood for the 30 metropolitan areas surveyed; the range is from 0.134 to 0.538 tons/year/person.

Table 11-2

\section{Resource Estimate for MSW Wood in Boston, Massachusetts Tons/year}

\begin{tabular}{|c|c|c|c|c|}
\hline & $\begin{array}{l}\text { Biomass } \\
\text { Fuel }\end{array}$ & $\begin{array}{l}\text { Mulch or } \\
\text { Firewood }\end{array}$ & $\begin{array}{l}\text { Combustion } \\
\text { or Landfill }\end{array}$ & Total \\
\hline Hauled with trash & & & 78,000 & 78,000 \\
\hline City streets and parks & & 5,000 & & 5,000 \\
\hline Wood waste processors: & & & & \\
\hline Kaknes Wood Products & 20,000 & 60,000 & & 80,000 \\
\hline Northern Tree Servicing & 13,000 & & & 13,000 \\
\hline JM Cook Company & 32,000 & & & 32,000 \\
\hline New England Recycling & & 8,000 & & 8,000 \\
\hline Bonnie \& Clyde Contr. & 5,000 & & & 5,000 \\
\hline Universities & & 1,000 & & 1,000 \\
\hline Utility tree trimming & & 20,000 & & 20,000 \\
\hline Private tree service co's & 60,000 & 60,000 & & 120,000 \\
\hline Total & 130,000 & 154,000 & 78,000 & 362,000 \\
\hline
\end{tabular}

\section{Industrial Wood Wastes}

As discussed above, Kaknes Wood Products, JM Cook Company, and New England Recycling process pallet wastes in the Boston metropolitan area. Kaknes did not divulge quantities; I assumed that they process 20,000 tons/year of pallet wood wastes, and that 10,000 tons/year go to mulch and 10,000 tons/year go to biomass fuel. JM Cook 
Company processes about 8,000 tons/year of pallet wood into biomass fuel, and New England Recycling processes about 10,000 tons/year of pallet wood into biomass fuel. Petrofiber in Henniker, New Hampshire processes about 33,000 tons/year of pallet wood wastes (at least $95 \%$ of the wood comes from pallets) into fuel for its parent company, Bioenergy, which operates a wood-fired power plant about two miles away. The company estimates that about 20,000 tons/year of this wood come from the Boston metropolitan area. No tipping fee is charged for clean pallet wood. Thus, the disposal cost to the Boston-area companies that haul pallet wastes up to Henniker is simply the transport cost, which is probably about $\$ 10 /$ ton for the 60-80 mile trip.

The Boston Area Yellow Pages list 12 companies under Pallets \& Skids; one company under Trusses-Construction; 27 companies under Lumber-Wholesale; 46 companies under Lumber-Retail; 83 companies under Cabinet Makers; 55 companies under Furniture Designers \& Custom Builders; 23 companies under Furniture Manufacturers; and 10 companies under Hardwoods. Three of the pallet companies from whom I was able to get information take their pallet wood waste to Petrofiber in Henniker, New Hampshire. The total amount for these three companies is about 3,000 tons/year, which is included in the 20,000 tons/year estimate for Petrofiber discussed above. Two of the other pallet companies from whom I was able to get information each produce less than 50 tons/year of wood waste, which mostly gets used as firewood but occasionally gets hauled away by the trash company. One pallet company operates a wood grinder and magnetic separator, and produces decorative chips from its pallet wood wastes. They did not divulge the amount; I have assumed 1,000 tons/year. Of the six pallet companies that did not give me information, I have assumed that three take their wood wastes to Petrofiber, and that the other three together generate about 1,000 tons/year of mulch. Thus, my total estimate for pallet companies in the Boston area (other than those who send wood to Petrofiber) is 2,000 tons/year of mulch, plus insignificant amounts of firewood and wood thrown away.

I got information from fifteen lumber companies (five wholesale, ten retail). About half of these companies do no significant amount of wood cutting (they are basically resellers), and thus produce no significant amounts of wood wastes. All of the lumber companies that generate wood wastes either burn the material in their own combustion facilities (for heating or drying), or give away wood as firewood. The quantities of wood waste generated by the lumber companies range from less than 10 tons/year up to about 100 tons/year. I estimate that lumber companies in the Boston area generate about 400 tons/year of fuel and 100 tons/year of firewood. The majority of woodworking companies (cabinet and furniture makers) produce very small amounts of wood wastes and simply put the wood in their trash bins. A few use wood scraps for fuel or give them away for firewood. I estimate that woodworking companies in the Boston area dispose of about 400 tons/year of wood wastes as trash, and give away about 100 tons/year as firewood.

Table 11-3 summarizes the estimated resources of industrial wood wastes in the Boston metropolitan area. The total estimate of 61,000 tons/year is equivalent to 0.031 tons/year/person based on the Boston metropolitan area population of 1,950,855. This is lower than the weighted average of 0.048 tons/year/person of industrial wood waste for the 30 metropolitan areas surveyed; the range is from 0.001 to 0.488 tons/year/person. 
Table 11-3

Resource Estimate for Industrial Wood Wastes in Boston, Massachusetts

Tons/year

\begin{tabular}{|c|c|c|c|c|c|}
\hline & Firewood & Mulch & $\begin{array}{c}\text { Hauled } \\
\text { w Trash }\end{array}$ & $\begin{array}{c}\text { Boiler } \\
\text { Fuel }\end{array}$ & Total \\
\hline \multicolumn{6}{|l|}{ Wood processors: } \\
\hline Kaknes Wood Prod & & 10,000 & & 10,000 & 20,000 \\
\hline JM Cook Co. & & & & 8,000 & 8,000 \\
\hline New England Recyc & & & & 10,000 & 10,000 \\
\hline Petrofiber $(\mathrm{NH})$ & & & & 20,000 & 20,000 \\
\hline Pallet companies* & & 2,000 & & & 2,000 \\
\hline Lumber companies & 100 & & & 400 & 500 \\
\hline Woodworking co's & 100 & & 400 & & 500 \\
\hline Total & 200 & 12,000 & 400 & 48,400 & 61,000 \\
\hline
\end{tabular}

*Most pallet company wastes are counted under Petrofiber.

\section{Construction/Demolition Wood Wastes}

Several companies in New England process C/D wastes and grind up the wood for fuel. KTI in Lewiston, Maine processes about 70,000 tons/year of C/D waste, about 30,000 tons of which come from the Boston area. This produces about 10,000 tons/year of biomass fuel from Boston area C/D waste. ERCO in Epping, New Hampshire receives a "huge" amount of C/D waste (the word used by the person at KTI), much of which comes from the Boston area. ERCO confirmed that they were processing large amounts of $\mathrm{C} / \mathrm{D}$ wood into biomass fuel, but declined to provide estimates of the quantities. My guess is on the order of 50,000 tons/year of C/D wood from the Boston area. A very large C/D wood processor in Johnstown, Rhode Island goes by the acronym NEED (New England Ecological Development). About $60 \%$ of the material processed by NEED comes from the Boston metropolitan area. About 60,000 tons/year of wood are recovered from Boston area waste, of which about 54,000 tons/year go to biomass fuel, 5,000 tons/year go to mulch, and 1,000 tons/year go to firelogs and pellets for wood stoves. A company called EIRCO in New Hampshire hauls and processes C/D wastes. It has contracts for closure of municipal landfills in Massachusetts and uses $\mathrm{C} / \mathrm{D}$ waste to cap the landfills. I did not get any information about wood recovered by EIRCO, if any. A company called AEI has recently bought a facility on Cape Cod and is just starting to process C/D waste. Their volume in the past year was negligible.

According to the Massachusetts Solid Waste Management Plan, the 2.9 million tons/year of $\mathrm{C} / \mathrm{D}$ waste disposed of in Massachusetts consists primarily of asphalt road pavement and concrete. If we assume that the Boston metropolitan area generates about $1 / 3$ of the $C / D$ waste in Massachusetts, and that $10 \%$ of the $\mathrm{C} / \mathrm{D}$ waste disposed of in landfills is wood, then approximately 100,000 tons/year of C/D wood from the Boston metropolitan area may be entering $\mathrm{C} / \mathrm{D}$ landfills in the state. Based on this (clearly incomplete) information about $\mathrm{C} / \mathrm{D}$ waste in the Boston area, I estimate a total of at least 220,000 tons/year of C/D wood generated, which is equivalent to 0.113 tons/year/person based on the Boston metropolitan area population of $1,950,855$. This is above the weighted average of 0.076 tons/year/person of $\mathrm{C} / \mathrm{D}$ wood for the 30 metropolitan areas surveyed; the range is from 0.015 to 0.250 tons/year/person. About 114,000 tons/year of C/D wood go to biomass fuel, 5,000 tons/year go to mulch, and 1,000 tons/year go to firelogs and pellets. 


\section{Supply Curve}

Figure 11-1 shows the supply curve for urban wood wastes in the Boston area. Table 11-4 shows the data and assumptions used to produce the supply curve.

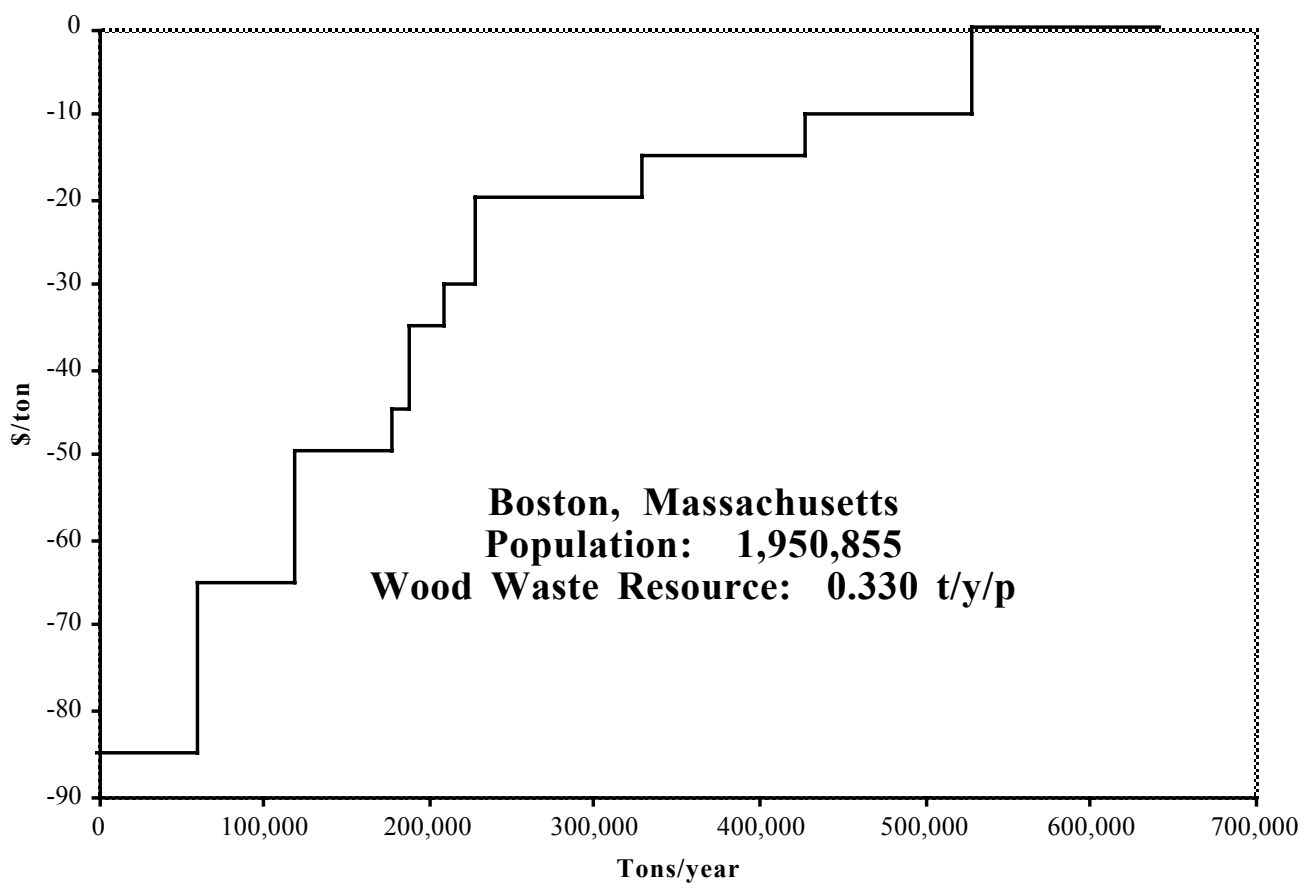

Figure 11-1. Supply Curve for Urban Wood Wastes in Boston, Massachusetts

Table 11-4

Data and Assumptions Used in Supply Curve for Boston

Tons/year Cumulative $\underline{\text { \$ton }}$

60,000

60,000

58,400

10,000

20,000

20,000

100,000

100,000

100,000

114,600
60,000

120,000

178,400

188,400

208,400

228,400

328,400

428,400

528,400

643,000

\section{Assumptions/Comments}

-85 Landfilled or incinerated with MSW or C/D

-65 Landfilled or incinerated with MSW or C/D

-50 Landfilled or incinerated with MSW or C/D

-45 Wood processors - stumps, large logs

-35 Wood processors - construction wood, fencing

-30 Wood processors - yard wastes

-20 Wood processors - tree wastes, industrial wood

-15 Wood processors - tree wastes, industrial wood

-10 Wood processors - tree wastes, industrial, C/D

0 Firewood, mulch, animal bedding - given away 


\section{Definition of the Boston Metropolitan Area Used in This Report}

The official 1990 definition of the metropolitan area by the Census Bureau is BostonLawrence Salem-Lowell-Brockton, and the population of this metropolitan area in 1990 was 3,783,817. Lawrence, Salem, Lowell, and Brockton are each about 20 or more miles from Boston, and have their own telephone directories. Including them (as well as a number of other towns not in the Boston Area Yellow Pages ${ }^{2}$ ) would have added greatly to the work involved in collecting data. Instead, I confined my data collection effort to the area covered by the Boston Area Yellow Pages. The cities and towns covered by this directory are listed in Table 11-5, along with the 1990 populations for these cities and towns. The total, 1,950,855, is the figure I used for all calculations in this section.

\section{Table 11-5
Boston -- Cities Included in Survey Area}

\begin{tabular}{lrlrlr} 
Arlington & 44,530 & Holbrook & 11,041 & Revere & 42,786 \\
Bedford & 12,996 & Lexington & 28,974 & Scituate & 16,783 \\
Belmont & 24,720 & Lincoln & 7,666 & Somerville & 76,210 \\
Boston* & 574,283 & Malden & 53,884 & Stoneham & 22,203 \\
Braintree & 33,836 & Medford & 57,407 & Wakefield & 24,825 \\
Brookline & 54,718 & Melrose & 28,150 & Waltham & 57,878 \\
Burlington & 23,302 & Milton & 25,725 & Watertown & 33,284 \\
Cambridge & 95,802 & Needham & 27,557 & Wellesley & 26,615 \\
Canton & 18,530 & Newton & 82,585 & Weston & 10,200 \\
Chelsea & 28,710 & North Reading & 12,002 & Westwood & 12,557 \\
Cohasset & 7,075 & Norwood & 28,700 & Weymouth & 54,063 \\
Dedham & 23,782 & Quincy & 84,985 & Winchester & 20,267 \\
Everett & 35,701 & Randolph & 30,093 & Winthrop & 18,127 \\
Hingham & 19,821 & Reading & 22,539 & Woburn & 35,943 \\
\cline { 2 - 6 } & & & & Total & $1,950,855$
\end{tabular}

*Boston includes Allston, Brighton, Charleston, Dorchester, East Boston, Hyde Park, Jamaica Plain, Mattapan, Roslindale, Roxbury, and West Roxbury.

\footnotetext{
${ }^{2}$ An example is the Marlborough, Concord, Acton Area Yellow Pages, which also include the towns of Carlisle, Boxborough, Maynard, Stow, Hudson, and Southborough.
} 
Harrisburg is the capital of Pennsylvania, and is on the east bank of the Susquehanna River in the south-central part of the state, in Dauphin County. Lebanon is about 25 miles east of Harrisburg, in Lebanon County; Carlisle is about 20 miles west of Harrisburg, in Cumberland County. York is considered a separate metropolitan area (population 417,848), although it is about the same distance (south) from Harrisburg as are Lebanon and Carlisle. There are many other towns included in the Harrisburg metropolitan area.

Wood processing companies in the Harrisburg area produce relatively high-value products such as furnish for particleboard plants and colored chips, primarily from clean pallet wood waste. They also produce small amounts of biomass fuel, although this is a break-even product at best in this area. The particleboard plant is in Winchester, Virginia (about 120 miles southwest of Harrisburg). The closest wood-burning power plant in Pennsylvania is Viking Energy in Northumberland (about 60 miles north of Harrisburg). Several wood processing companies in the Harrisburg area said that Viking pays such low amounts for biomass fuel that it is not worth processing wood to meet their tight specifications and hauling it that distance; cheaper wood disposal options are available locally.

Table 12-1 summarizes the data collected on urban wood resources in the Harrisburg area. The estimated total urban wood waste resource, 0.245 tons/year/person, is below the weighted average of 0.333 tons/year/person for the 30 metropolitan areas surveyed; the range for the 30 cities is from 0.156 to 0.829 tons/year/person. A biomass project developer in the Harrisburg area might be able to secure about 50,000 to 100,000 tons/year of feedstock at a low cost, by diverting some of the wood currently going to landfills or incinerators, and obtaining some of the wood being given away as firewood and mulch. This could produce 3 to $10 \mathrm{MW}$ of electricity.

Table 12-1

Resource Estimate for Urban Wood Waste in Harrisburg, Pennsylvania

\begin{tabular}{|c|c|c|c|c|c|}
\hline \multirow[b]{2}{*}{ Use or Disposal Method: } & \multicolumn{4}{|c|}{ Tons/Year } & \multirow[b]{2}{*}{$\begin{array}{l}\text { Price, } \\
\text { \$/ton }\end{array}$} \\
\hline & $\begin{array}{l}\text { MSW } \\
\text { Wood }\end{array}$ & $\begin{array}{l}\text { Industr. } \\
\text { Wood }\end{array}$ & $\begin{array}{c}\text { C/D } \\
\text { Wood }\end{array}$ & Total & \\
\hline Firewood & 15,000 & 5,000 & & 20,000 & 0 \\
\hline Mulch & 58,000 & 5,000 & & 63,000 & 0 \\
\hline Animal bedding & & 1,300 & & 1,300 & 0 \\
\hline Furnish for particleboard & & 10,000 & & 10,000 & 0 to -20 \\
\hline Biomass fuel & & 6,800 & & 6,800 & 0 to -20 \\
\hline Landfill or incinerator & 20,000 & & 23,000 & 43,000 & -35 to -64 \\
\hline Total & 93,000 & 28,100 & 23,000 & 144,100 & \\
\hline Total, tons/year/person & 0.158 & 0.048 & 0.039 & 0.245 & \\
\hline
\end{tabular}

\section{Municipal Solid Waste (MSW) Collection and Disposal}

The Harrisburg Refuse Incinerator (also listed as the Harrisburg Steam Generating Facility) burns all of the residential trash from the city of Harrisburg and several nearby municipalities. (In addition, this facility and the others listed below receive large amounts of solid waste from New York, New Jersey, Maryland, and other nearby states.) City trucks pick up the residential trash and bring it to the plant. Commercial haulers bring industrial and commercial solid wastes. The Harrisburg Refuse Incinerator's tipping fees 
are negotiated with each hauler; the fee charged to the public is about $\$ 64 /$ ton. In addition to the wood debris that is mixed in with the waste, the plant receives occasional loads of pallets, skids, tree debris, etc. In addition, grease that is recovered from grease traps and dewatered is combusted in the facility. The plant has two combustion units that are about 25-30 years old; each unit has a rated capacity of 360 tons/day.

I obtained the Pennsylvania Department of Environmental Protection's County Waste Destination Reports for Dauphin, Lebanon, and Cumberland Counties for the first three quarters of 1997. I annualized these data to produce the following estimate of the total solid waste disposed of in the three counties containing the Harrisburg metropolitan area:

\begin{tabular}{|c|c|c|c|c|}
\hline $\begin{array}{l}\text { Approx. tons/year (first } 3 \\
\text { quarters of } 1997 \text { times 4/3): }\end{array}$ & $\begin{array}{l}\text { Dauphin } \\
\text { County }\end{array}$ & $\begin{array}{l}\text { Lebanon } \\
\text { County }\end{array}$ & $\begin{array}{l}\text { Cumberland } \\
\text { County }\end{array}$ & Total \\
\hline Municipal & 183,000 & 66,000 & 150,000 & 399,000 \\
\hline Construction & 61,000 & 14,000 & 40,000 & 115,000 \\
\hline Total solid waste* & 244,000 & 80,000 & 190,000 & 514,000 \\
\hline
\end{tabular}

*Excludes the following categories also reported in the Pennsylvania County Waste Destinations Report: residual, sewage sludge, infectious, ash residual, and asbestos.

The largest waste destinations for municipal waste from the three counties are listed below along with their tipping fees:

Harrisburg Refuse Incinerator, Harrisburg

Modern Landfill, York

Maximum Disposal Fee, \$/ton

R\&A Bender Landfill, Scotland

MSW

Cumberland County Landfill, Shippensburg

39.26

Dauphin Meadows Landfill, Millersburg

York County Resource Recovery Center, York

Construction waste was disposed of primarily at the landfills (but not the two combustion facilities) listed above. Assuming the municipal waste contains about 5\% wood and the construction waste contains about $20 \%$ wood, then the amounts of MSW wood and C/D wood waste from the Harrisburg metropolitan area entering waste disposal facilities along with other solid wastes are about 20,000 tons/year and 23,000 tons/year, respectively.

\section{MSW Wood (Primarily Tree and Yard Wastes)}

The Harrisburg Parks \& Recreation Department gives away their tree trimming wastes as firewood and mulch. In 1996, the three counties in the Harrisburg area recycled an estimated total of 15,000 tons of leaf and yard waste to compost and mulch, according to the state Department of Environmental Protection.

I spoke to five of the largest trash hauling companies in the area. None of them have wood grinding or recycling operations, although one company was in the process of starting a wood grinding program. This company operates a transfer station and a land clearing 
company, and plans to sell mulch when its wood grinder begins operating. The transfer station charges a tipping fee of $\$ 63.25 /$ ton. Two of the trash haulers mentioned that they haul pallets and some C/D wood to two wood grinding companies (Laukemann Recycling and Zeager Brothers Inc.), discussed below.

GPU provides electric service in the Harrisburg area. GPU's tree trimming supervisor said their contractors (Asplundh, Independent Tree Service, York Tree Service, and others) are responsible to dispose of the wood generated by their tree trimming operations. Asplundh Tree Expert Company operates about 60 crews in the region of Pennsylvania bounded by Reading, Johnstown, Indiana, and State College. Based on population I estimated that Asplundh has about 16 crews operating in the Harrisburg metropolitan area, each generating an average of 1,000 tons/year of wood from tree trimming, for a total estimate of about 16,000 tons/year. The wood is usually left onsite as firewood and mulch at the request of the owners. If the wood is removed, it is usually left as mulch with companies or people who want it, such as golf courses. Assuming Asplundh is the largest but not the only tree trimming contractor working for utilities in the Harrisburg area, I estimate that a total of 20,000 tons/year of firewood and mulch are generated from these activities.

The Harrisburg Yellow Pages list 30 tree service companies (including Asplundh, discussed above). I called all of these companies and was able to obtain useful information from 11 of them. Assuming there are six companies that operate a total of 15 crews, and that the other 23 companies operate one crew each, my estimate of the total amount of wood generated from tree trimming and removal operations in the Harrisburg metropolitan area is about 38,000 tons/year (10,000 tons/year to firewood and 28,000 to mulch).

Table 12-2 summarizes the estimated resources of MSW wood in the Harrisburg metropolitan area. The total estimate, 93,000 tons/year (of which about 20,000 tons/year enter landfills), is equivalent to 0.158 tons/year/person based on the Harrisburg metropolitan area population of 587,986. This is below the weighted average of 0.209 tons/year/person of MSW wood for the 30 metropolitan areas, which range from 0.134 to 0.538 tons/year/person.

\section{Table 12-2 \\ Resource Estimate for MSW Wood in Harrisburg, Pennsylvania Tons/year}

\begin{tabular}{|c|c|c|c|c|}
\hline & Mulch* & Firewood & Landfill & Total \\
\hline Hauled with trash & & & 20,000 & 20,000 \\
\hline Municipal yard waste recycl. & 15,000 & & & 15,000 \\
\hline Utility tree trimming & 15,000 & 5,000 & & 20,000 \\
\hline Private tree service co's & 28,000 & 10,000 & & 38,000 \\
\hline Total & 58,000 & 15,000 & 20,000 & 93,000 \\
\hline
\end{tabular}

*"Mulch" includes compost in this case.

\section{Industrial Wood Wastes}

The Harrisburg Yellow Pages list eleven companies under Pallets and Skids, only four of which are in the local area; no local companies under Trusses-Construction; one local company under Lumber-Wholesale; 16 local companies under Lumber-Retail; and 14 local companies under Cabinet Makers or Furniture Designers \& Custom Builders 
(woodworking companies). In addition, I found two unlisted companies that process wood wastes (almost entirely pallet wastes).

The largest pallet manufacturing and recycling company I found in the Harrisburg area was Pallet Outlet Company Inc. in Biglerville. This company produces 8,000-10,000 new pallets/day, dismantles about 3,000 pallets/day, and ships about 5,000 reconditioned pallets/day. In the process, the company generates about 50-60 tons/day of wood waste, or about 12,000-16,000 tons/year. The waste wood is fed automatically to an in-line grinder and is sold to the highest-value markets available, which at this time are furnish for particleboard plants, high-quality mulch (including colored chips), and biomass fuel (which is a breakeven product at best). The primary outlets for these products are south of Pennsylvania, such as Winchester, Virginia, the site of the particleboard plant. The Viking biomass power plant north of Harrisburg is not a customer because it pays too low a price.

Zeager Brothers Inc. operates a wood recycling yard that accepts pallet wood and other clean wood wastes, and produces mulch, colored chips, animal bedding, and bulking agents for sewage sludge (now discontinued). The wood is processed through a tub grinder and a metal removal unit, and then screened and re-ground. Zeager Brothers' estimated total production of recycled wood products is in the range of 7,000-10,000 tons/year. I did not get information on tipping fees or product prices.

A company named Laukemann Recycling (and/or Enviroproducts) in Mechanicsburg was identified by one of the waste haulers as the place they take pallets and clean C/D wood. Laukemann Recycling grinds the wood into mulch. However, they have recently cut back on the amount of wood they are accepting, because they have "more product on hand than needed". I interpret this to mean that they are not able to market their mulch profitably. Presently they are only taking in about 2 tons/week of wood waste (i.e., about 100 tons/year). I do not know how this rate compares to their previous or "normal" rate.

One company listed under Pallets \& Skids, Jack's Cooperage, is a barrel-making company that repairs a small number of pallets as a sidelight. This company does not generate a significant quantity of wood waste, and the wood that it does generate is used as fuel onsite. My guesstimate is less than 100 tons/year.

A pallet company named Brykris Industries in Lykens uses its wood scraps as fuel in a relatively inefficient furnace and heating system that consumes most of the wood waste generated by the business. Small amounts of animal bedding and firewood are sold or given away. My guesstimate is 1,000 tons/year total, of which half is used onsite as fuel and half is given away as animal bedding and firewood. The manager told me that most of the pallet companies in the area simply burn their waste wood out back.

Righi Pallet Company in Newville also uses its wood scraps as fuel or firewood. They also give some wood to a company that grids it to mulch -- about 40 tons/year. My guesstimate for the total amount of wood waste generated by Righi is 100-200 tons/year.

Adding up the numbers above for pallet wood wastes gives a range of about 20,00028,000 tons/year. I chose 25,000 tons/year as a reasonable estimate, and assigned it to the following categories: 10,000 tons/year sold as furnish for particleboard plants (i.e., most of the production of Pallet Outlet Company); 9,000 tons/year of firewood and mulch (combined); 5,000 tons/year of biomass fuel; and 1,000 tons/year of animal bedding.

The one wholesale lumber company in the Harrisburg area, Lafferty \& Company Inc. in Lemoyne, operates a planing mill, molder, etc., and uses almost all of the resulting sawdust and shavings as fuel to displace oil and gas in its drying kilns. The company also 
gives away some sawdust and shavings as animal bedding. The manager estimated the total quantity generated at about 600 cubic feet per day, or about 2,000 tons/year.

The 16 retail lumber companies in the Harrisburg area all give away their small quantities of waste wood as firewood, or in a few cases as animal bedding. They put pieces of wood in bins for people to take, and some companies also put pallets out by the road for people to take. The total amount is probably about 1,000 tons/year.

The 14 woodworking companies (cabinet and custom furniture makers) in the Harrisburg area are all very small companies. They produce very small amounts of wood scraps that are used by family and friends, and/or given away as firewood. My estimate for the total amount of wood generated by these companies is 100 tons/year or less.

Table 12-3 summarizes the estimated resources of industrial wood wastes in the Harrisburg metropolitan area. The total estimate of 28,100 tons/year is equivalent to 0.048 tons/year/person based on the Harrisburg metropolitan area population of 587,986. This is the same as the weighted average of 0.048 tons/year/person of industrial wood waste for the 30 metropolitan areas surveyed; the range is from 0.001 to 0.488 tons/year/person.

Table 12-3

Resource Estimate for Industrial Wood Wastes in Harrisburg, Pennsylvania Tons/year

\begin{tabular}{|c|c|c|c|c|c|}
\hline & $\begin{array}{l}\text { Firewood } \\
\text { or Mulch }\end{array}$ & $\begin{array}{c}\text { Biomass } \\
\text { Fuel }\end{array}$ & $\begin{array}{l}\text { Animal } \\
\text { Beddin }\end{array}$ & $\begin{array}{l}\text { Furnish } \\
\text { for Pbd }\end{array}$ & Total \\
\hline Pallet companies & 9,000 & 5,000 & 1,000 & 10,000 & 25,000 \\
\hline Lumber companies & 900 & 1,800 & 300 & & 3,000 \\
\hline Woodworking co's & 100 & & & & 100 \\
\hline Total & 10,000 & 6,800 & 1,300 & 10,000 & 28,100 \\
\hline
\end{tabular}

\section{Construction/Demolition Wood Wastes}

The Harrisburg Yellow Pages list seven local companies under Demolition Contractors and one company under Land Clearing \& Leveling (which turned out to be a subsidiary of a large local trash hauling company). I called all of the local demolition companies and found that all except one company take their C/D material to landfills and pay tipping fees in the range of $\$ 35-45 /$ ton. One company (L\&W Demolition) reportedly grinds C/D wood to mulch, but that company did not return my calls.

I did not get quantitative estimates from the demolition contractors, but the state report cited earlier (see the table in the subsection on MSW Collection and Disposal) provided data on "construction" waste sent to landfills from the three counties in the Harrisburg metropolitan area. Based on that information, I estimate that 23,000 tons/year of C/D wood waste from the Harrisburg metropolitan area are disposed of in landfills. The estimated total of 23,000 tons/year is equivalent to 0.039 tons/year/person based on the Harrisburg metropolitan area population of 587,986. This is below the weighted average of 0.076 tons/year/person of $\mathrm{C} / \mathrm{D}$ wood for the 30 metropolitan areas surveyed; the range is from 0.015 to 0.250 tons/year/person. 


\section{Supply Curve}

Figure 12-1 shows the supply curve for urban wood wastes in the Harrisburg-LebanonCarlisle area. Table 12-4 shows the data and assumptions used to produce the supply curve.

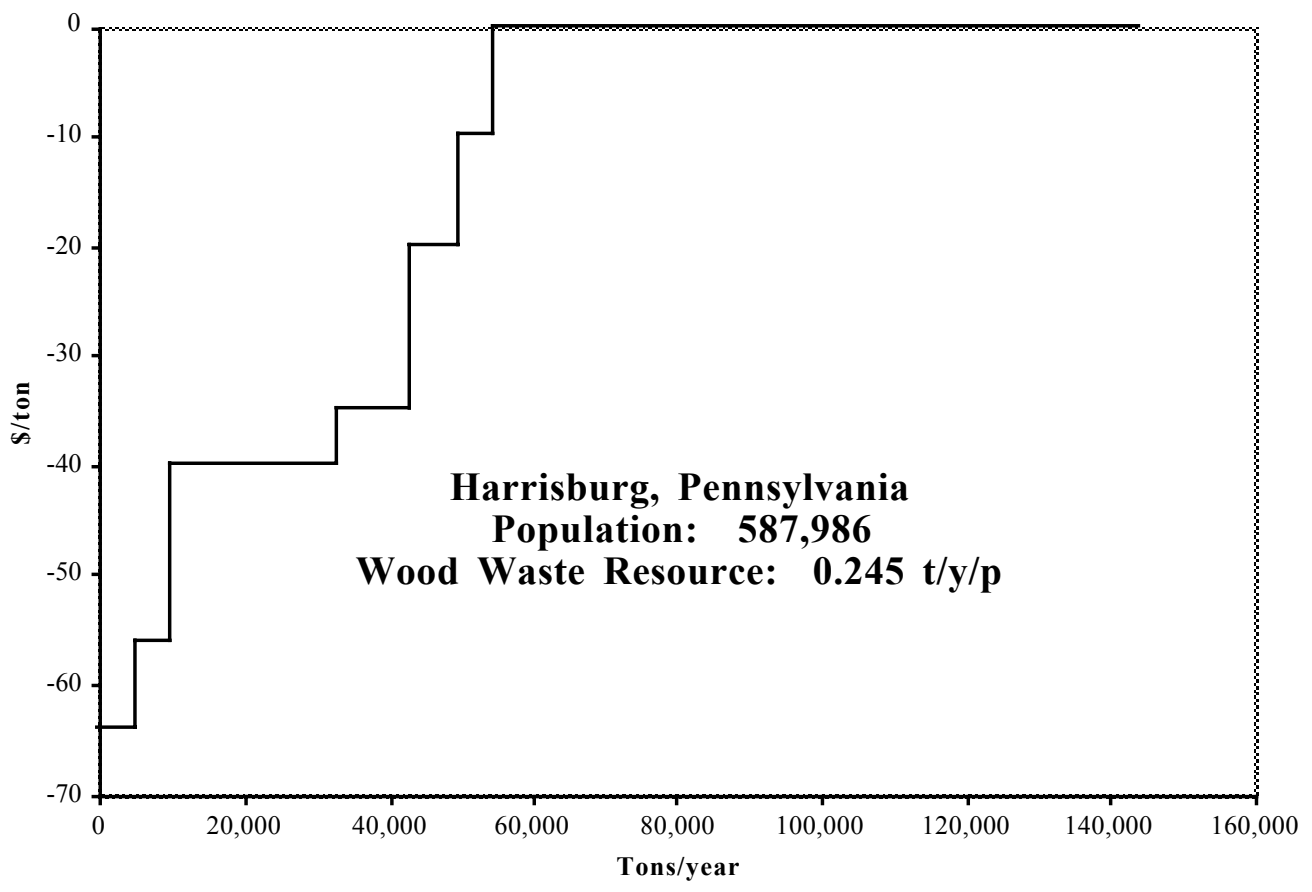

Figure 12-1. Supply Curve for Urban Wood Wastes in Harrisburg, Pennsylvania

Table 12-4

Data and Assumptions Used in Supply Curve for Harrisburg

Tons/year Cumulative $\frac{\text { \$/ton }}{5,000}$ Assumptions/Comments

\begin{tabular}{|c|c|c|c|}
\hline 5,000 & 5,000 & -64 & Incinerated with MSW - Harrisburg \\
\hline 5,000 & 10,000 & -56 & Incinerated with MSW - York County \\
\hline 23,000 & 33,000 & -40 & Landfilled with MSW and C/D \\
\hline 10,000 & 43,000 & -35 & Landfilled with MSW and C/D \\
\hline 6,800 & 49,800 & -20 & Wood processors - tree wastes, industrial wood \\
\hline 5,000 & 54,800 & -10 & Wood processors - tree wastes, industrial wood \\
\hline 5,000 & 59,800 & 0 & Wood processors - tree wastes, industrial wood \\
\hline 84,300 & 144,100 & 0 & Animal bedding, firewood, mulch - given away \\
\hline
\end{tabular}


Altoona is in Blair County, about 80 miles east of Pittsburgh, between Johnstown and State College. The Pennsylvania Railroad, now Conrail, founded Altoona in 1849 during construction of the first railroad over the Alleghenies. For years the town's economy depended on railroad building and repair shops; other industries have since developed.

Table 13-1 summarizes the data collected on urban wood resources in the Altoona area. The estimated total urban wood waste resource, 0.430 tons/year/person, is above the weighted average of 0.333 tons/year/person for the 30 metropolitan areas surveyed; the range for the 30 cities is from 0.156 to 0.829 tons/year/person. The urban wood waste in the Altoona area is more heavily weighted towards industrial wood wastes than in many of the other cities surveyed. There are profitable markets for most of this industrial wood waste: wood chips sold to a paper mill, furnish for a particleboard plant, and decorative mulch. A biomass project developer in the Altoona area would probably be able to secure only about 10,000 to 20,000 tons/year of feedstock at a low cost, by diverting some of the wood currently going to landfills, and obtaining some of the wood being given away as firewood and mulch. This could produce on the order of 1 to $2 \mathrm{MW}$ of electricity.

Table 13-1

Resource Estimate for Urban Wood Waste in Altoona, Pennsylvania

\begin{tabular}{|c|c|c|c|c|c|}
\hline \multirow[b]{2}{*}{ Use or Disposal Method: } & \multicolumn{4}{|c|}{ Tons/Year } & \multirow[b]{2}{*}{$\begin{array}{c}\text { Price, } \\
\text { \$/ton }\end{array}$} \\
\hline & $\begin{array}{l}\text { MSW } \\
\text { Wood }\end{array}$ & $\begin{array}{c}\text { Industr. } \\
\text { Wood }\end{array}$ & $\begin{array}{c}\text { C/D } \\
\text { Wood }\end{array}$ & Total & \\
\hline Paper mill or particleboard & & 14,700 & & 14,700 & 24 \\
\hline Animal bedding & & 4,300 & & 4,300 & 10 \\
\hline Firewood & 5,000 & 600 & & 5,600 & 0 \\
\hline Mulch (ground cover) & 15,000 & 8,700 & & 23,700 & 0 \\
\hline Landfill & 4,400 & & 3,400 & 7,800 & -35 to -40 \\
\hline Total & 24,400 & 28,300 & 3,400 & 56,100 & \\
\hline Total, tons/year/person & 0.187 & 0.217 & 0.026 & 0.430 & \\
\hline
\end{tabular}

\section{Municipal Solid Waste (MSW) Collection and Disposal}

All trash pickup and hauling in Altoona and Blair County is done by private haulers. The Blair County Solid Waste Department gave me data for both MSW and C/D waste disposal in 1996 and the first half of 1997: about 88,000 tons/year of MSW and about 17,000 tons/year of $\mathrm{C} / \mathrm{D}$ waste, all disposed of in landfills. Assuming the MSW contains about $5 \%$ wood and the C/D waste contains about $20 \%$ wood, I estimate that about 4,400 tons/year of MSW wood and about 3,400 tons/year of C/D wood are being landfilled.

\section{MSW Wood (Primarily Tree and Yard Wastes)}

The Blair County Solid Waste Department operates a composting facility for yard waste. The manager estimated that about 4,000 tons/year of brush are processed through a tub grinder and added to the compost piles. The largest trash hauler in the area, Burgmeier's Hauling, also operates a tub grinder, and reportedly uses it primarily to grind pallets to supply chips to a local paper mill. (Burgmeier's personnel did not return my calls.)

The Altoona Yellow Pages list eight tree service companies. I contacted all of these companies, and got information from three. Based on their information, I estimate that a 
total of about 12 crews perform tree trimming and removal work in the Altoona area, generating about 12,000 tons/year of wood. My guesstimate is that about 4,000 tons/year end up as firewood and 8,000 tons/year go to mulch.

The electric utility in the Altoona area, GPU, contracts with Asplundh and other tree service companies for tree trimming services along their utility lines. Based on information provided by the Asplundh regional manager (see Harrisburg section), I estimate that utility tree trimming work in the Altoona area generates about 4,000 tons/year of wood. Most of this wood is left on site for the land owners to use as firewood and mulch. My guesstimate is that about 1,000 tons/year end up as firewood and 3,000 tons/year go to mulch.

Table 13-2 summarizes the estimated resources of MSW wood in the Altoona metropolitan area. The total estimate, 24,400 tons/year (of which about 4,400 tons/year enter landfills), is equivalent to 0.187 tons/year/person based on the Altoona metropolitan area population of 130,542. This is below the weighted average of 0.209 tons/year/person of MSW wood for the 30 metropolitan areas, which range from 0.134 to 0.538 tons/year/person.

\section{Table 13-2 \\ Resource Estimate for MSW Wood in Altoona, Pennsylvania Tons/year}

\begin{tabular}{|c|c|c|c|c|}
\hline & Mulch & Firewood & Landfill & Total \\
\hline Hauled with trash & & & 4,400 & 4,400 \\
\hline Municipal yard waste recycl. & 4,000 & & & 4,000 \\
\hline Utility tree trimming & 3,000 & 1,000 & & 4,000 \\
\hline Private tree service co's & 8,000 & 4,000 & & 12,000 \\
\hline Total & 15,000 & 5,000 & 4,400 & 24,400 \\
\hline
\end{tabular}

\section{Industrial Wood Wastes}

The Altoona Yellow Pages list two companies under Pallets and Skids; no local companies under Trusses-Construction; two companies under Lumber-Wholesale; 12 companies under Lumber-Retail; and 8 companies under Cabinet Makers or Furniture Designers \& Custom Builders (woodworking companies). In addition, one trash hauling and recycling company processes wood wastes (mostly pallet wastes).

One pallet company (Conrad Lumber) grinds its wood scraps to mulch, and sells sawdust to an Allegheny particleboard plant, and also for animal bedding. They would not give me an estimate of the quantities involved other than to say they were significant amounts. My guess is a total of 10,000 tons/year -- 5,000 tons/year to mulch, 3,000 to particleboard furnish, and 2,000 to animal bedding. The other company listed under Pallets \& Skids was primarily a fencing company. They appear to do very little pallet business, and produce an insignificant amount of wood waste. Burgmeier's Hauling reportedly grinds pallet wood wastes in a tub grinder and sells the wood chips to a local paper mill. I did not get any information from this company. My guess is a total of 5,000 tons/year.

One wholesale lumber company, Krumenacker Lumber Company, produces about 1,700 tons/year of sawdust that goes to animal bedding; about 1,700 tons/year of wood chips that go to a paper mill; and about 1,700 tons/year of bark that goes to mulch. The other wholesale lumber company, George Long \& Son, does exactly the same things with its three waste streams (about 1,600 tons/year of sawdust to animal bedding; about 5,000 
tons/year of wood chips to the paper mill; and about 2,000 tons/year of bark mulch). All of these products produce income; they should be considered by-products, not wastes. Appleton Paper Company in Roaring Springs (about 40 miles away) pays about \$24/ton for wood chips (delivered). Farmers pay about $\$ 22 /$ farm truck load (maybe \$10/ton) for animal bedding. I did not find out the price of bark mulch.

The 12 retail lumber companies in the Altoona area all give away their small quantities of waste wood as firewood, or in a few cases as animal bedding. They put pieces of wood in bins for people to take, and some companies also put pallets out by the road for people to take. The total amount is probably about 500 tons/year.

The 8 woodworking companies (cabinet and custom furniture makers) in the Altoona area are all very small companies. They produce very small amounts of wood scraps that are used by family and friends, and/or given away as firewood. My estimate for the total amount of wood generated by these companies is 100 tons/year or less.

Table 13-3 summarizes the estimated resources of industrial wood wastes in the Altoona metropolitan area. The total estimate of 28,300 tons/year is equivalent to 0.217 tons/year/person based on the Altoona metropolitan area population of 130,542. This is above the weighted average of 0.048 tons/year/person of industrial wood waste for the 30 metropolitan areas surveyed; the range is from 0.001 to 0.488 tons/year/person.

Table 13-3

Resource Estimate for Industrial Wood Wastes in Altoona, Pennsylvania Tons/year

\begin{tabular}{|c|c|c|c|c|c|}
\hline & Firewood & Mulch & $\begin{array}{l}\text { Animal } \\
\text { Beddin }\end{array}$ & $\begin{array}{l}\text { Pbd or } \\
\text { Paper* }\end{array}$ & Total \\
\hline Pallet companies & & 5,000 & 2,000 & 8,000 & 15,000 \\
\hline Lumber companies & 500 & 3,700 & 2,300 & 6,700 & 13,200 \\
\hline Woodworking co's & 100 & & & & 100 \\
\hline Total & 600 & 8,700 & 4,300 & 14,700 & 28,300 \\
\hline
\end{tabular}

*Furnish to particleboard plants or wood chips to paper mills.

\section{Construction/Demolition Wood Wastes}

The Altoona Yellow Pages list six local companies under Demolition Contractors and no companies under Land Clearing \& Leveling. I called all of the local demolition companies and found that all of them take their C/D material to landfills and pay tipping fees in the range of $\$ 35-45 /$ ton. I did not get quantitative estimates from the demolition contractors, but the Blair County Solid Waste Department recorded about 17,000 tons/year of C/D waste disposed of in 1996. Assuming 20\% wood in the C/D waste, I estimate that about 3,400 tons/year of C/D wood waste from the Altoona metropolitan area are disposed of in landfills. The estimated total of 3,400 tons/year is equivalent to 0.026 tons/year/person based on the Altoona metropolitan area population of 130,542. This is below the weighted average of 0.076 tons/year/person of $\mathrm{C} / \mathrm{D}$ wood for the 30 metropolitan areas surveyed; the range is from 0.015 to 0.250 tons/year/person. 


\section{Supply Curve}

Figure 13-1 shows the supply curve for urban wood wastes in the Altoona area. Table 134 shows the data and assumptions used to produce the supply curve.

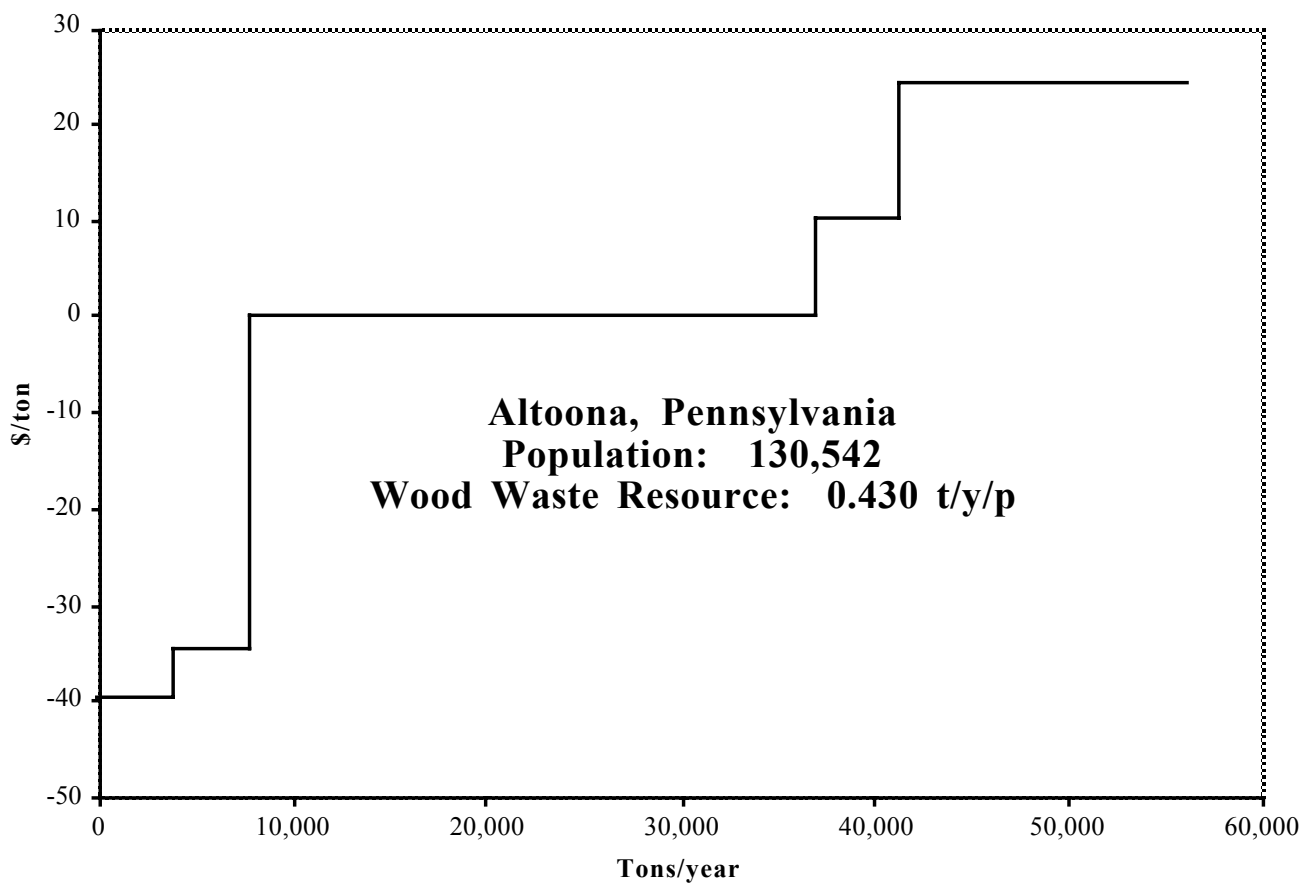

Figure 13-1. Supply Curve for Urban Wood Wastes in Altoona, Pennsylvania

Table 13-4

Data and Assumptions Used in Supply Curve for Altoona

Tons/year Cumulative \$/ton

3,900

3,900

29,300

4,300

14,700

\section{3,900}

7,800

37,100

41,400

56,100
Assumptions/Comments

Landfilled with MSW and C/D

-35 Landfilled with MSW and C/D

$0 \quad$ Firewood and mulch - given away

10 Animal bedding - sold

24 Pulp chips and furnish for particleboard - sold 
Hagerstown, in Washington County, is the largest community in western Maryland, with a mixture of old and new buildings interspersed with many trees and public parks. Two major interstate highways, I-70 running east-west and I-81 running north-south, intersect at Hagerstown. Except for a few busy streets, shopping malls, etc., the city has an open, rural feeling. Modern industrial facilities dot the landscape along the interstates.

Table 14-1 summarizes the data collected on urban wood resources in the Hagerstown area. The estimated total urban wood waste resource, 0.358 tons/year/person, is above the weighted average of 0.333 tons/year/person for the 30 metropolitan areas surveyed; the range for the 30 cities is from 0.156 to 0.829 tons/year/person. A biomass project developer in the Hagerstown area would probably be able to secure about 10,000 to 20,000 tons/year of feedstock at a low cost, by diverting some of the wood currently going to landfills, and obtaining some of the wood being given away as firewood and mulch. This could produce on the order of 1 to $2 \mathrm{MW}$ of electricity.

Table 14-1

Resource Estimate for Urban Wood Waste in Hagerstown, Maryland

\begin{tabular}{|c|c|c|c|c|c|}
\hline \multirow[b]{2}{*}{ Use or Disposal Method: } & \multicolumn{4}{|c|}{ Tons/Year } & \multirow[b]{2}{*}{$\begin{array}{c}\text { Price, } \\
\text { \$/ton } \\
\end{array}$} \\
\hline & $\begin{array}{l}\text { MSW } \\
\text { Wood }\end{array}$ & $\begin{array}{c}\text { Industr. } \\
\text { Wood }\end{array}$ & $\begin{array}{c}\text { C/D } \\
\text { Wood }\end{array}$ & Total & \\
\hline Firewood & 6,000 & 1,600 & & 7,600 & 0 \\
\hline Mulch (ground cover) & 24,000 & 1,000 & & 25,000 & 0 \\
\hline Animal bedding & & 600 & & 600 & 0 \\
\hline Furnish for particleboard & & 1,000 & & 1,000 & -10 to -20 \\
\hline Landfill & 6,000 & & 3,200 & 9,200 & -35 \\
\hline Total & 36,000 & 4,200 & 3,200 & 43,400 & \\
\hline Total, tons/year/person & 0.297 & 0.035 & 0.026 & 0.358 & \\
\hline
\end{tabular}

\section{Municipal Solid Waste (MSW) Collection and Disposal}

Hagerstown contracts with BFI for residential trash and yard waste pickup. BFI has a Recyclery outside of town but does no wood grinding there. Washington County has two solid waste facilities: Resh Road II sanitary landfill (116,000 tons of MSW in 1995); and Washington County Rubble Landfill (about 16,000 tons/year of C/D debris). Tipping fees are about $\$ 35 /$ ton for commercial haulers. Members of the public who obtain permits from the County can drop waste at the landfills or transfer stations for free. The County operates a wood grinder at the rubble landfill, grinding pallet wood and brush only, and selling the mulch for \$12/ton. C/D wood is not recovered; it goes into the rubble landfill. Assuming $5 \%$ wood in the MSW and $20 \%$ wood in the C/D waste, I estimate that about 6,000 tons/year of MSW wood waste and about 3,200 tons/year of C/D wood waste from the Hagerstown metropolitan area are disposed of in the county landfills.

\section{MSW Wood (Primarily Tree and Yard Wastes)}

The Washington County recycling manager would not divulge the amount of wood recycled in the municipal yard waste program. I estimate that the amount would be similar to that in Altoona, a city of comparable size and geography: about 4,000 tons/year. 
The Hagerstown Yellow Pages list 9 tree service companies. I called all of these companies and got information from five of them. Based on this information, I estimate that there are a total of about 16 crews operating in the Hagerstown area, generating about 16,000 tons/year of wood. I guesstimate that about 4,000 tons/year go to firewood and 12,000 tons/year go to mulch. Several companies mentioned taking excess wood or diseased wood to the rubble landfill, but I believe this is not a large quantity.

Electric utility service within the Hagerstown city limits is provided by Hagerstown City Light Department. They contract to one of the local tree service companies, Antietam Tree $\&$ Turf, for tree trimming work. The wood generated from this activity is included in the private tree service company estimate above.

Outside the city limits (throughout Washington County), Allegheny Power provides electric service. They contract to several tree service companies (primarily Gilbert Company; also Davey Tree, Asplundh, and Aaron Tree) who operate an estimated total of 10 crews and generate about 10,000 tons/year of wood waste from tree trimming along utility lines in Washington County. My guesstimate is that 2,000 tons/year go to firewood and 8,000 tons/year go to mulch.

Table 14-2 summarizes the estimated resources of MSW wood in the Hagerstown area. The total estimate, 36,000 tons/year (of which about 6,000 tons/year enter landfills), is equivalent to 0.297 tons/year/person based on the Hagerstown metropolitan area population of 121,393. This is above the weighted average of 0.209 tons/year/person of MSW wood for the 30 metropolitan areas, which range from 0.134 to 0.538 tons/year/person.

Table 14-2

Resource Estimate for MSW Wood in Hagerstown, Maryland Tons/year

\begin{tabular}{|c|c|c|c|c|}
\hline & Mulch & Firewood & Landfill & Total \\
\hline Hauled with trash & & & 6,000 & 6,000 \\
\hline Municipal yard waste recycl. & 4,000 & & & 4,000 \\
\hline Utility tree trimming & 8,000 & 2,000 & & 10,000 \\
\hline Private tree service co's & 12,000 & 4,000 & & 16,000 \\
\hline Total & 24,000 & 6,000 & 6,000 & 36,000 \\
\hline
\end{tabular}

\section{Industrial Wood Wastes}

The Hagerstown Yellow Pages list three companies under Pallets and Skids; one local company under Trusses-Construction; no local companies under Lumber-Wholesale; 9 companies under Lumber-Retail; and 15 companies under Cabinet Makers or Furniture Designers \& Custom Builders (woodworking companies). One of the pallet companies listed in the Hagerstown Yellow Pages is Pallet Outlet Company Inc. in Biglerville, Pennsylvania, which is about halfway (30 miles) between Hagerstown and Harrisburg. I interviewed the president of Pallet Outlet while gathering data in Harrisburg, and talked to him again while in Hagerstown. He receives about 4 or 5 loads of pallets per week from the Hagerstown area. (Separately, BFI in Hagerstown told me that they haul loads of pallets from Hagerstown to Pallet Outlet.) I estimate that this represents about 2,000 tons/year of wood waste generated from Hagerstown area pallets, which is ground and sold as furnish for particleboard plants, high-quality mulch, and biomass fuel. 
Shank Pallet Recyclers in Greencastle, Pennsylvania recycles pallets from the Hagerstown area, generating about 100 tons/year of wood waste, which goes mostly to firewood. Rodgers Pallet Company in Shady Grove, Pennsylvania burns all of their wood waste onsite, including about 100 tons/year from the Hagerstown area.

Cavco Homes in Cavetown, Maryland manufactures pre-built homes, wall units, doors, window sashes, etc. They give away about 6 pickup truckloads per week of sawdust for animal bedding, or about 600 tons/year. Cavco burns all of the wood scraps they generate in their own boiler. I did not get an estimate of the quantity; my guess is 1,000 tons/year.

The 9 retail lumber companies in the Hagerstown area all give away small quantities of waste wood as firewood, or in a few cases as animal bedding. The total amount is probably about 300 tons/year.

The 15 woodworking companies (cabinet and custom furniture makers) in the Hagerstown area are all very small companies. They produce very small amounts of wood scraps that are used by family and friends, and/or given away as firewood. My estimate for the total amount of wood generated by these companies is 100 tons/year or less.

Table 14-3 shows the estimated resources of industrial wood wastes in the Hagerstown area. The total estimate of 4,200 tons/year is equivalent to 0.035 tons/year/person based on the Hagerstown metropolitan area population of 121,393. This is below the weighted average of 0.048 tons/year/person of industrial wood waste for the 30 metropolitan areas surveyed; the range is from 0.001 to 0.488 tons/year/person.

Table 14-3

Resource Estimate for Industrial Wood Wastes in Hagerstown, Maryland Tons/year

\begin{tabular}{|c|c|c|c|c|c|}
\hline & Firewood & Mulch & $\begin{array}{l}\text { Animal } \\
\text { Beddin }\end{array}$ & $\begin{array}{c}\text { Furnish } \\
\text { to Pbd }\end{array}$ & Total \\
\hline Pallet companies & 200 & 1,000 & & 1,000 & 2,200 \\
\hline Lumber companies & 300 & & & & 300 \\
\hline Woodworking co's & 1,100 & & 600 & & 1,700 \\
\hline Total & 1,600 & 1,000 & 600 & 1,000 & 4,200 \\
\hline
\end{tabular}

\section{Construction/Demolition Wood Wastes}

The Hagerstown Yellow Pages list six local companies under Demolition Contractors and no companies under Land Clearing \& Leveling. I called all of the local demolition companies and found that they take their $\mathrm{C} / \mathrm{D}$ material to the county rubble landfill. The Maryland Department of the Environment recorded 6,777 tons of C/D waste disposed of in the last five months of 1995, which I translated to about 16,000 tons/year. (The rubble landfill opened in August 1995, and Washington County had not yet reported its 1996 data.) Assuming 20\% wood in the C/D waste, I estimate that about 3,200 tons/year of C/D wood waste from the Hagerstown metropolitan area are disposed of in the landfill. The estimated total of 3,200 tons/year is equivalent to 0.026 tons/year/person based on the Hagerstown metropolitan area population of 121,393. This is below the weighted average of 0.076 tons/year/person of C/D wood for the 30 metropolitan areas surveyed; the range is from 0.015 to 0.250 tons/year/person. 


\section{Supply Curve}

Figure 14-1 shows the supply curve for urban wood wastes in the Hagerstown area. Table 14-4 shows the data and assumptions used to produce the supply curve.

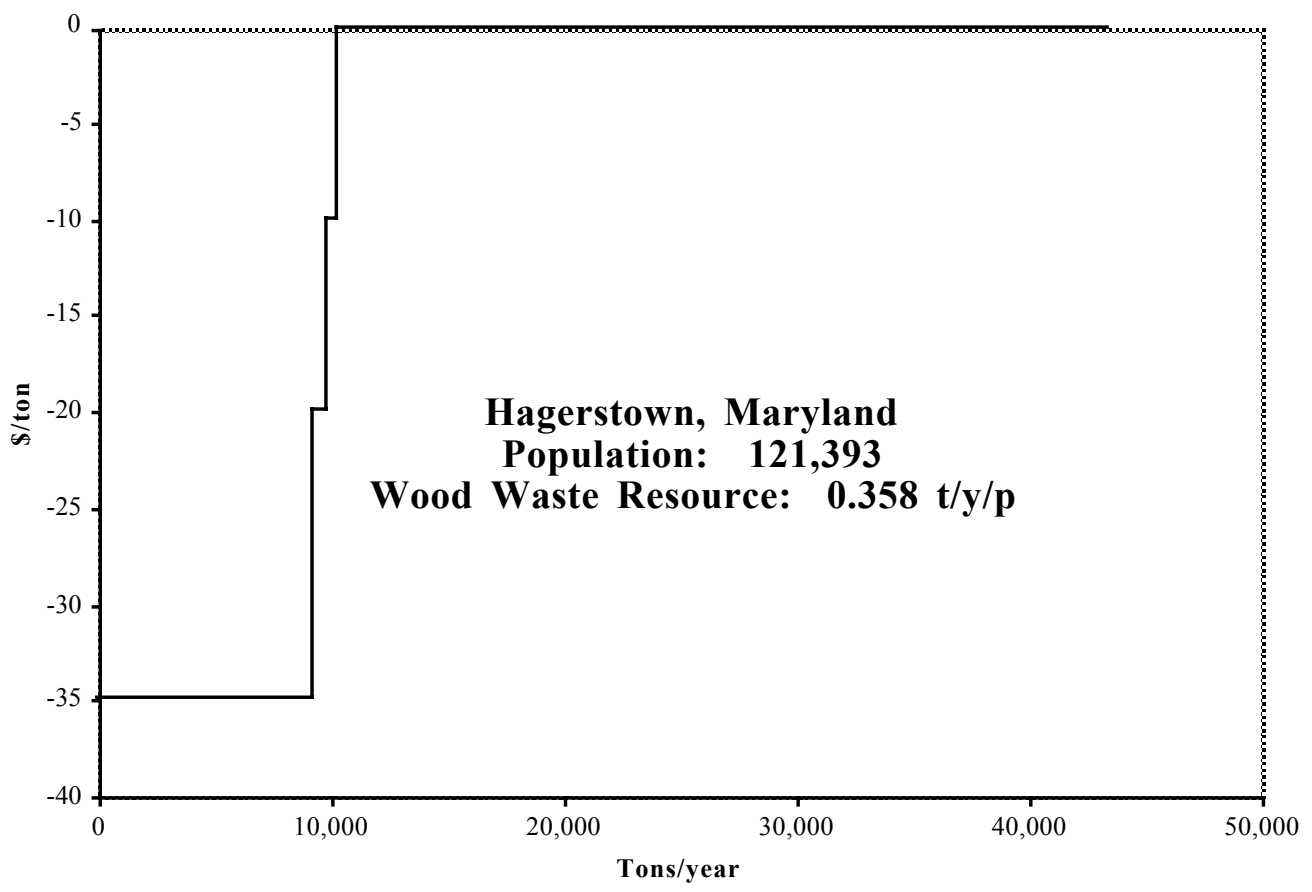

Figure 14-1. Supply Curve for Urban Wood Wastes in Hagerstown, Maryland

Table 14-4

Data and Assumptions Used in Supply Curve for Hagerstown

Tons/year Cumulative $\frac{\text { \$/ton }}{9,200}$

9,200

500

500

33,200
9,200

9,700

10,200

43,400
Assumptions/Comments

Landfilled with MSW and C/D

-20 Wood processors - industrial wood

-10 Wood processors - industrial wood

0 Animal bedding, firewood and mulch - given away 
Washington, DC is somewhat unique among the metropolitan areas included in this urban biomass resource study. It is comprised of the District of Columbia, parts of Arlington and Fairfax Counties in Virginia, and Montgomery and Prince George's Counties in Maryland. The primary "industry" throughout the metropolitan area is government. There is a great deal of office space filled with government officials and contractors, supported by a large infrastructure of service industries, as well as urban and suburban residential areas.

My primary resource was the Northern Virginia Yellow Pages. It appeared to give a full representation of companies in the District of Columbia as well as the Maryland and Virginia counties mentioned above. I confirmed this when I spent some time in both Maryland and DC, and compared those areas' Yellow Pages sections with the Northern Virginia book that I used as a primary source. I also obtained all of the necessary Maryland government agency office numbers from a Montgomery County phone book.

Table 15-1 summarizes the data collected on urban wood resources in the Washington, DC area. The estimated total urban wood waste resource, 0.156 tons/year/person, is the lowest of the 30 metropolitan areas surveyed, which range from 0.156 to 0.829 , and average 0.333 tons/year/person. The Washington, DC area generates almost no industrial wood wastes such as pallet wastes. About $25 \%$ of the wood waste in the metropolitan area is disposed of in landfills or waste-to-energy plants. A biomass project developer in the Washington, DC area would probably be able to secure about 300,000 to 400,000 tons/year of feedstock at a low cost, and produce 20 to $40 \mathrm{MW}$ of electricity.

Table 15-1

Resource Estimate for Urban Wood Waste in Washington, DC

\begin{tabular}{|c|c|c|c|c|c|}
\hline \multirow[b]{2}{*}{ Use or Disposal Method: } & \multicolumn{4}{|c|}{ Tons/Year } & \multirow[b]{2}{*}{$\begin{array}{l}\text { Price, } \\
\text { \$/ton }\end{array}$} \\
\hline & $\begin{array}{l}\text { MSW } \\
\text { Wood }\end{array}$ & $\begin{array}{l}\text { Industr. } \\
\text { Wood }\end{array}$ & $\begin{array}{c}\text { C/D } \\
\text { Wood }\end{array}$ & Total & \\
\hline Firewood & 100,000 & 2,300 & & 102,300 & 0 \\
\hline Mulch (ground cover) & 340,000 & & 20,000 & 360,000 & 0 \\
\hline Animal bedding & & 200 & & 200 & 0 \\
\hline Landfill or incinerator & 96,000 & 500 & 55,000 & 151,500 & -44 \\
\hline Total & 536,000 & 3,000 & 75,000 & 614,000 & \\
\hline Total, tons/year/person & 0.137 & 0.001 & 0.019 & 0.156 & \\
\hline
\end{tabular}

\section{Municipal Solid Waste (MSW) Collection and Disposal}

District of Columbia. The District of Columbia generates about 750,000-800,000 tons/year of solid waste, per the DC Solid Waste Management Administration. Two District-owned transfer stations process about 221,000 tons/year of residential trash and send it to Fairfax County, where it is incinerated. Another 14,000 tons/year of DC's residential trash go directly to the incinerator. The disposition of the commercial trash is not tracked by the Solid Waste Management Administration. I believe most of it (over 500,000 tons/year) ends up in Virginia and Pennsylvania waste-to-energy plants and landfills.

Northern Virginia. Fairfax County collects trash from residences in the cities of Arlington and Alexandria (with about $13 \%$ of the county's population). Private haulers provide service to the rest of the residences in Fairfax County. Separate handling and collection of 
yard debris is mandatory. The county provides vacuum leaf service to about $11 \%$ of the residences, and operates a mulch giveaway program. Fairfax County and District of Columbia trash trucks haul to the I-66 Transfer Station and the I-95 Landfill and Resource Recovery Facility. Homeowners can also haul trash to the I-66 Transfer Station. A manager at the Fairfax County Solid Waste Division estimated that about 600,000 tons/year of solid waste are generated and disposed of in Fairfax County.

Wood grinding takes place at both the C/D landfill and the sanitary landfill at Lorton. A mobile grinding machine spends alternate weeks at the two facilities. The Fairfax County Mulch Hotline recording says that double shredded wood and leaf mulch are available at the I-95 Sanitary Landfill in Lorton and at the I-66 Transfer Station. Deliveries are also available on Wednesdays and Thursdays. The operator at the I-95 Sanitary Landfill said that they charge no tipping fee for wood, and referred me to Fairfax County Solid Waste Disposal and Resource Recovery Division personnel for further information.

The Arlington County Refuse Collection Supervisor said that all the residential trash in the county goes to the Ogden Martin waste-to-energy facility in Arlington. Residents are provided with 95 gallon refuse carts, which can hold a lot of brush and other residential wood wastes. The residential trash in the city of Arlington (31,800 customers) amounts to about 43,000 tons/year. The rated capacity of the waste-to-energy plant is about 975 tons/day (about 300,000 tons/year). Commercial haulers can take industrial or C/D wastes to any disposal facility of their choice.

The Arlington County Leaf Mulch and Wood Chip Recycling recording indicates that wood chips are available for $\$ 30$ per 2.5 cubic yards, or $\$ 50$ per 5 cubic yards, delivered to the buyer's site. (These prices are equivalent to about $\$ 40 /$ ton and $\$ 33 /$ ton, respectively.) The wood chips are given away free at the two County composting sites.

Maryland. The Montgomery County Solid Waste Services Department managers I spoke to said that about half of the trash in the county is hauled by private haulers, and about half by public haulers. Tipping fees for commercial haulers are in the $\$ 43-44 /$ ton range. There is no wood recycling program other than yard waste and brush. This program produced about 9,500 tons of mulch in fiscal year 1997 (July 1996 - June 1997). MSW sampling and composition studies in 1995 showed that combined residential and commercial solid waste in Montgomery County contained about 3.3 weight percent wood, most of which was derived from lumber and pallets. MSW from commercial sources averaged about $5.2 \%$ wood, and residential trash averaged less than $3 \%$.

A manager at Prince George's County Waste Management Division said that residential trash is picked up by private haulers under contract to the county. Yard waste is taken to a site near the Western Branch wastewater treatment plant in Upper Marlboro; compost is produced by Maryland Environmental Services and marketed through nurseries. Residential trash is disposed of at two county-owned landfills: Brown Station Road and Sandy Hill. (Sandy Hill is owned by the county and operated by Waste Management, Inc.) Commercial haulers take solid waste to wherever the tipping fees are lowest; most of it goes through transfer stations to mega-landfills in southern Pennsylvania or northern Virginia. There are two licensed C/D landfills in PG County: Ritchie Reclamation Project, and Cross Trails Rubble Fill (aka Brandywine Enterprises). I obtained the following data from the Maryland Department of the Environment about the permitted solid waste acceptance facilities in Montgomery and Prince George's Counties: 


\begin{tabular}{|c|c|c|c|c|}
\hline & Type of Facility & Ownership & Tons/year & Notes \\
\hline \multicolumn{5}{|l|}{ Montgomery County } \\
\hline Layhill/Bonifant & Rubble landfill & County & 2,600 & 1 \\
\hline Mont. Cty RRF & Waste to energy & Ogden Martin & 422,648 & 2 \\
\hline Oaks & Municipal landfill & County & 156,457 & 3 \\
\hline Shady Grove TS & Transfer station & County & 532,561 & 4 \\
\hline Prince George's County & & & & 5 \\
\hline Brandywine RLF & Rubble landfill & Private & 267,777 & 6 \\
\hline Brown Station B & Municipal landfill & County & 262,615 & 7 \\
\hline Ritchie Land Rec. & Rubble landfill & Private & 271,688 & 8 \\
\hline CDP/Sandy Hill & Municipal landfill & County & 361,034 & 9 \\
\hline
\end{tabular}

Notes:

1. Converted from 1,125 cubic yards in a six-month period assuming 1.14 tons/cubic yard.

2. All waste to Montgomery County Resource Recovery Facility is delivered from Shady Grove Transfer Station. 1,509,457 cubic yards of mixed residential and commercial waste $(\mathrm{MR} \& \mathrm{CW})$.

3. Composition (tons/year): ash 117,$428 ; \mathrm{C} / \mathrm{D} \&$ land clearing debris (LCD) 21,960; non-processible bulky wastes (NPBW) 16,977; asbestos 93.

4. Composition (tons/year): MR\&CW 419,809; ash 69,262; NPBW 21,569; CD\&LCD 19,713; recycle 2,119; asbestos 88 .

5. County population 779,684 .

6. C/D debris. Essentially no wood; just concrete, block, brick, road material.

7. Composition (tons/year): residential 131,046; commercial 89,566; bulky 8,180; C/D-highway 5,830; LCD 3,885; shredder fluff 23,170; tires 907; metals \& wood 31. Overall bulk density: 0.55 tons/cubic yard.

8. C/D debris. 11,855 tons/year stumps/brush, mostly chipped and recycled. Bulk densities (tons/cubic yard): stumps/brush: 0.30; overall average: 0.50; dirt, concrete, asphalt: 1.5 .

9. Mixed residential and commercial, plus tires. Started operation 8/95.

Summary. Tabulated below is a summary of the amounts of solid waste generated and disposed of in the DC metropolitan area. The total is about 2,900,000 tons/year, or about 0.74 tons/year/person. I assumed that all of the MSW in the Washington, DC metropolitan area contains an average of $3.3 \%$ wood. Unless specifically noted otherwise (e.g., note 6 in the table above), I assumed that $\mathrm{C} / \mathrm{D}$ debris contains an average of $20 \%$ wood. As a result of these assumptions, I estimate that about 96,000 tons/year of MSW wood waste, and about 55,000 tons/year of C/D wood waste, are included in the solid waste going to landfills and waste-to-energy plants in the Washington, DC metropolitan area.

Summary of Estimated MSW and C/D Debris Generation, tons/year

Washington, DC

Fairfax County

Arlington County (guess)

Montgomery County (rounded)

Prince George's County (rounded)

Total

\begin{tabular}{|c|c|}
\hline MSW & C/D \\
\hline 800,000 & \\
\hline 600,000 & \\
\hline 300,000 & \\
\hline 580,000 & 3,000 \\
\hline 620,000 & 539,000 \\
\hline $2,900,000$ & 542,000 \\
\hline
\end{tabular}




\section{MSW Wood (Primarily Tree and Yard Wastes)}

As discussed in the subsection above, an estimated 96,000 tons/year of MSW wood waste are included in the solid waste going to landfills and waste-to-energy plants in the area. None of the waste hauling companies I talked to in the Washington, DC area (Waste Management, BFI, USA Waste, and several others) do any wood separation or grinding.

Fairfax, Arlington, Montgomery, and Prince George's Counties have yard waste recycling programs that produce and give away mulch: an estimated 9,500 tons/year in Montgomery County, and comparable amounts in the other three counties. My estimate of the amount of mulch generated from yard waste in the metropolitan area is 40,000 tons/year.

The electric utilities serving the metropolitan area are PEPCO (serving all of DC and most of Montgomery and Prince George's Counties), and Virginia Power (serving the northern Virginia counties). Both utilities contract primarily to Asplundh for tree trimming services, with a total of about 100 crews operating in the metropolitan area, producing an estimated 100,000 tons/year of mulch and firewood (assumed split: 25,000 firewood, 75,000 mulch). Almost all of this material is given away to land owners or to others who want it.

The Yellow Pages list 213 tree service companies (108 in northern Virginia, 98 in Maryland, 7 in the District of Columbia). I called about half of these companies, and based on that information I estimate that there are a total of about 300 crews operating in the metropolitan area, generating about 300,000 tons/year of wood from tree trimming and removals (75,000 tons/year of firewood and 225,000 tons/year of mulch).

Table 15-2 summarizes the estimated resources of MSW wood in the Washington, DC metropolitan area. The total estimate, 536,000 tons/year (of which about 96,000 tons/year enter landfills), is equivalent to 0.137 tons/year/person based on the metropolitan area population of 3,923,574. This is near the bottom of the range of MSW wood for the 30 metropolitan areas, which range from 0.134 to 0.538 , and average 0.209 tons/year/person.

Table 15-2

Resource Estimate for MSW Wood in Washington, DC Tons/year

\begin{tabular}{|c|c|c|c|c|}
\hline & Mulch & Firewood & Landfill & Total \\
\hline Hauled with trash & & & 96,000 & 96,000 \\
\hline Municipal yard waste recycl. & 40,000 & & & 40,000 \\
\hline Utility tree trimming & 75,000 & 25,000 & & 100,000 \\
\hline Private tree service co's & 225,000 & 75,000 & & 300,000 \\
\hline Total & 340,000 & 100,000 & 96,000 & 536,000 \\
\hline
\end{tabular}

\section{Industrial Wood Wastes}

The Yellow Pages list two local companies under Pallets and Skids; no local companies under Trusses-Construction; 20 local companies under Lumber-Wholesale; 16 companies under Lumber-Retail; and 194 companies under Cabinet Makers or Furniture Designers \& Custom Builders (woodworking companies). I was unable to locate any pallet wood recycling businesses in the DC area. I believe the area's pallet needs are serviced primarily from the Baltimore and Richmond areas. The one local pallet company I spoke to takes a small amount of pallet wood waste to the landfill. My estimate for pallet wood waste generated in the Washington, DC metropolitan area is a nominal 1,000 tons/year. 
The 36 wholesale and retail lumber companies in the Washington, DC area all use or give away small quantities of waste wood as firewood, or in a few cases as animal bedding. The total amount is probably about 1,000 tons/year. The 194 woodworking companies (cabinet and custom furniture makers) in the Washington, DC area are all very small companies. They produce a total of 1,000 tons/year or less of wood scraps that are used by family and friends, and/or given away as firewood.

Table 15-3 summarizes the estimated resources of industrial wood wastes in the DC metropolitan area. The total estimate of 3,000 tons/year is equivalent to about 0.001 tons/year/person based on the metropolitan area population of 3,923,574. This is at the low end of the range of estimates found in the 30-city sample (which range from 0.001 to 0.488 and average 0.048 tons/year/person).

Table 15-3

Resource Estimate for Industrial Wood Wastes in Washington, DC Tons/year

\begin{tabular}{|c|c|c|c|c|c|}
\hline & Firewood & Mulch & $\begin{array}{l}\text { Animal } \\
\text { Beddin }\end{array}$ & Landfill & Total \\
\hline Pallet companies & 500 & & & 500 & 1,000 \\
\hline Lumber companies & 800 & & 200 & & 1,000 \\
\hline Woodworking co's & 1,000 & & & & 1,000 \\
\hline Total & 2,300 & & 200 & 500 & 3,000 \\
\hline
\end{tabular}

\section{Construction/Demolition Wood Wastes}

The Yellow Pages list 31 local companies under Demolition Contractors and four companies under Land Clearing \& Leveling. All of the demolition contractors I talked to haul their solid waste to landfills. As discussed in the MSW subsection above, about 55,000 tons/year of C/D wood from the DC metropolitan area are disposed of in landfills.

In Prince George's County, Brandywine Enterprises landfill receives essentially no wood; just concrete, bricks, block, and road material. The Ritchie Land Reclamation C/D landfill separates and grinds wood, and uses it as wet weather cover, road cover, etc. The owner is planning to expand the grinding operation from the current level of 5,000-6,000 tons/year and begin marketing mulch sometime in the future.

The land clearing companies grind the wood they generate onsite, and use the mulch in the landscaping process. One company has a wood grinding yard near Baltimore, and grinds wood for other land clearing companies as well as its own wood, selling mulch and topsoil. None of these companies was willing to give me an estimate of the quantity of wood they grind. My guess is that about 20,000 tons/year ends up as mulch.

Based on this information, about 55,000 tons/year of C/D wood end up in landfills, and another 20,000 tons/year of land clearing wood end up as mulch. The estimated total of 75,000 tons/year is equivalent to 0.019 tons/year/person based on the metropolitan area population of $3,923,574$. This is near the bottom of the range of the estimates found in the 30 -city survey for C/D wood wastes, which range from 0.015 to 0.250 and average 0.076 tons/year/person. 


\section{Supply Curve}

Figure 15-1 shows the supply curve for urban wood wastes in the Washington, DC area. Table 15-4 shows the data and assumptions used to produce the supply curve.

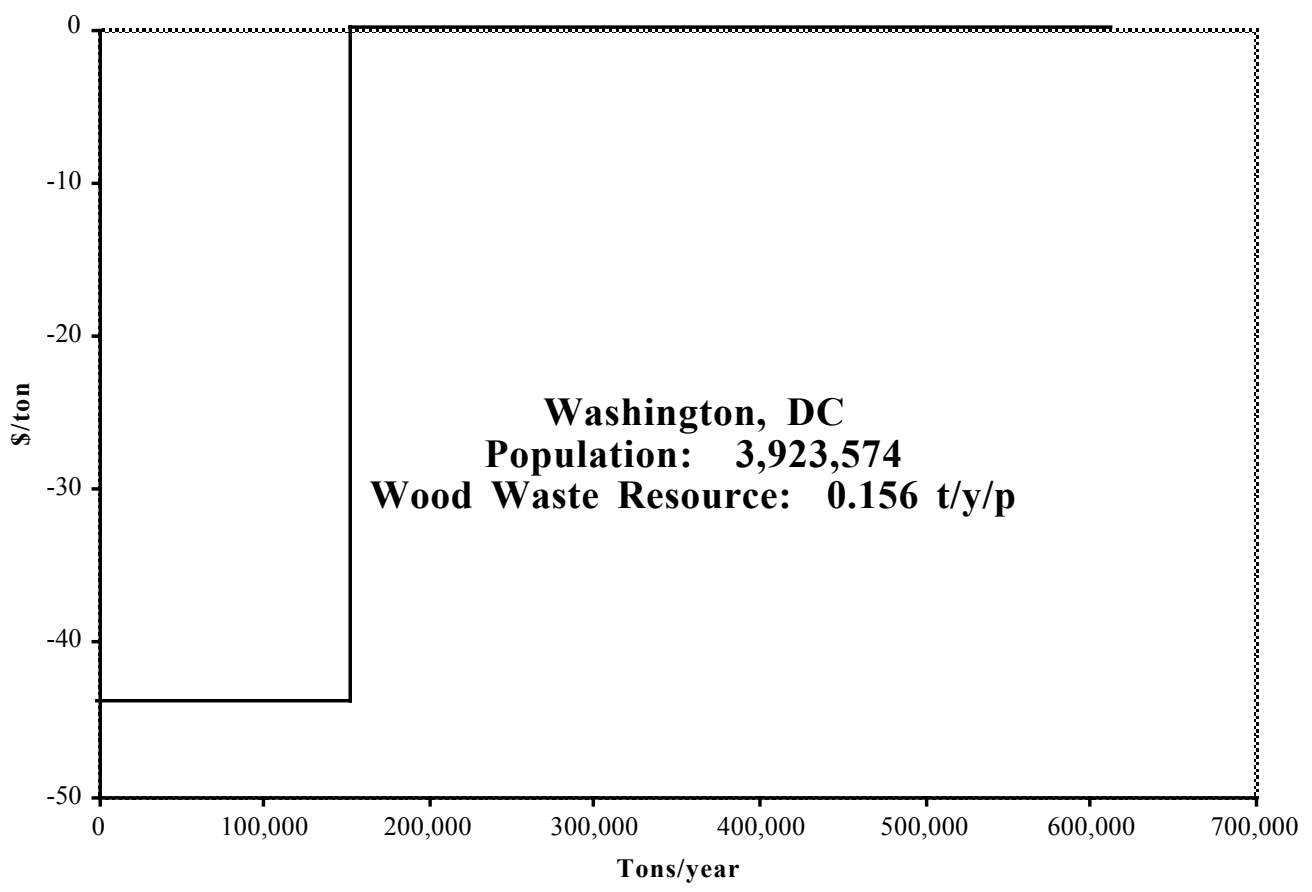

Figure 15-1. Supply Curve for Urban Wood Wastes in Washington, DC

Table 15-4

Data and Assumptions Used in Supply Curve for Washington, DC

Tons/year Cumulative \$/ton Assumptions/Comments

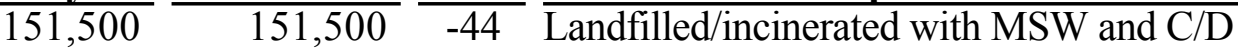

$462,500 \quad 614,000 \quad 0 \quad$ Animal bedding, firewood and mulch - given away 
The Richmond-Petersburg, Virginia metropolitan area is comprised of five cities and nine counties. All of these entities except one county are members of the Central Virginia Waste Management Authority (CVWMA). The cities are adjacent to the counties (rather than part of counties as they are in other states). I obtained data from CVWMA and from interviews, and obtained telephone numbers from the Richmond and Petersburg telephone books.

Richmond, the capital of Virginia, straddles the James River and lies on Interstate 95, about 75 miles south of Washington, DC. Petersburg, on the Appomatox River, is also on Interstate 95 about 20 miles farther south. Chesterfield and Henrico Counties are adjacent to Richmond. These three entities (Richmond, Chesterfield, and Henrico) each had 1990 populations of about 210,000 to 220,000 people. The populations of the other cities and counties range from about 6,000 to about 60,000. City populations have been declining, while the counties and the overall area have been growing, with a diverse range of government, manufacturing, service, and trade industries. Manufacturing is playing a larger role in the region's economy, and the forest products industry is very significant.

Table 16-1 summarizes the data collected on urban wood resources in the RichmondPetersburg area. The estimated total urban wood waste resource, 0.829 tons/year/person, is the highest in the 30 metropolitan areas surveyed, which range from from 0.156 to 0.829 , and average 0.333 tons/year/person. In both the industrial wood and C/D wood categories, generation rates are unusually high because of the industrial and population growth in the area. Wood recovery rates are high because the large forest products industry in the area provides a ready market for saw logs, pulp chips, and biomass fuel.

Table 16-1

\section{Resource Estimate for Urban Wood Waste in Richmond-Petersburg, Virginia}

\begin{tabular}{|c|c|c|c|c|c|}
\hline \multirow[b]{2}{*}{ Use or Disposal Method: } & \multicolumn{4}{|c|}{ Tons/Year } & \multirow[b]{2}{*}{$\begin{array}{c}\text { Price } \\
\text { S/ton }\end{array}$} \\
\hline & $\begin{array}{l}\text { MSW } \\
\text { Wood }\end{array}$ & $\begin{array}{c}\text { Industr. } \\
\text { Wood }\end{array}$ & $\begin{array}{c}\text { C/D } \\
\text { Wood }\end{array}$ & Total & \\
\hline Pulp chips & & 108,000 & 20,000 & 128,000 & 12 \\
\hline Biomass fuel & & 92,000 & 20,000 & 112,000 & 9 to -42 \\
\hline Mulch & 191,000 & 32,000 & 80,000 & 303,000 & 9 to -42 \\
\hline Animal bedding & & 12,000 & & 12,000 & 9 to -42 \\
\hline Firewood & 36,000 & 1,000 & & 37,000 & 0 \\
\hline Saw logs & & & 20,000 & 20,000 & -15 \\
\hline Landfill & 30,000 & & 76,000 & 106,000 & -21 to -50 \\
\hline Total & 257,000 & 245,000 & 216,000 & 718,000 & \\
\hline Total, tons/year/person & 0.297 & 0.283 & 0.250 & 0.829 & \\
\hline
\end{tabular}

\section{Municipal Solid Waste (MSW) Collection and Disposal}

CVWMA estimated that 1,426,640 tons of solid waste were generated and disposed of in landfills in 1995 (not counting large quantities coming in from the DC metropolitan area and other states). There are no waste-to-energy facilities in the CVWMA area. The following table shows the estimated amounts of solid waste generated in the CVWMA area in 1990, and the type of facilities (public or private landfills) that received the wastes: 


\begin{tabular}{|c|c|c|c|}
\hline & Public Landfills & Private Landfills & Total \\
\hline Residential wastes & 177,000 & 518,000 & $695,000 *$ \\
\hline Commercial wastes & 144,000 & 164,000 & 308,000 \\
\hline Other** & & & 424,000 \\
\hline Total & & & $1,427,000$ \\
\hline
\end{tabular}

Notes: *Estimated by CVWMA using EPA's recommended rate of 4.4 pounds of waste per person per day (0.803 tons/year/person).

**By difference. Assumed to be $\mathrm{C} / \mathrm{D}$ plus land clearing waste.

The CVWMA Waste Management Plan (1992 -- out-of-date information) lists the following sanitary landfills in the area and their "potential future annual tonnages":

\begin{tabular}{|c|c|}
\hline Private Landfills & Potential Future Annual Tonnage \\
\hline Shoosmith Brothers & 520,000 \\
\hline BFI King and Queen & 285,000 \\
\hline BFI Cumberland & 285,000 \\
\hline Chambers & $1,092,000$ \\
\hline \multicolumn{2}{|l|}{ Public Landfills } \\
\hline Hanover & 37,500 \\
\hline Henrico \#1 & 110,000 \\
\hline Goochland (2) & 4,700 \\
\hline Chesterfield & 88,000 \\
\hline Hopewell & 31,200 \\
\hline Prince George & 31,000 \\
\hline Petersburg & 35,000 \\
\hline Total & $2,519,400$ \\
\hline
\end{tabular}

All four of the private sanitary landfills listed above came online in about 1992. USA Waste now has two large sanitary landfills in the area as well: Amelia, which receives about 600,000 tons/year, and Charles City, which receives about 700,000 tons/year, mostly from New York, Washington, DC, etc. In addition to the 12 sanitary landfills listed above, there are about 14 debris landfills that take $\mathrm{C} / \mathrm{D}$ and land clearing debris. Tipping fees at the county owned landfills are about $\$ 50 /$ ton. Tipping fees at the privately owned landfills range from about $\$ 21$ to about $\$ 48 /$ ton.

In the City of Richmond, city trucks pick up residential trash and haul it to a transfer station owned by USA Waste. USA Waste hauls the trash to its Charles City County landfill. The city collects residential yard waste and grinds the brush to mulch, producing about 16,000 tons/year of mulch. Chesterfield and Henrico Counties have similar programs and each produce about 16,000 tons/year of mulch. The mulch is given away to the public.

The CVWMA estimated that its recycling program diverted 81,665 tons/year of "arboreal" material and 38,007 tons/year of "wood/pallets" material from landfills in 1995. The arboreal waste consisted of 29,165 tons/year of leaves and 52,500 tons/year of brush. Households produced 68,540 tons/year of the arboreal waste, and non-household sources produced 13,125 tons/year (all of which was brush). The mulch produced by the City of 
Richmond and the counties of Chesterfield and Henrico is included in these amounts. (It should be noted that the City of Richmond stopped participating in the CVWMA recycling program in 1997 and is conducting its own recycling program.)

At USA Waste's Qualla Road debris landfill, tipping fees are \$8.50/cubic yard for debris and $\$ 6.50 /$ cubic yard for stumps and brush. (These are equivalent to about $\$ 8 /$ ton for debris and \$21/ton for stumps and brush.) About 225,000 cubic yards/year of C/D and land clearing debris enter the landfill, which the landfill manager estimated to be roughly half wood by volume. Assuming 113,000 cubic yards/year of wood in this debris at 3.3 cubic yards/ton, this is about 34,000 tons/year of wood entering the Qualla Road landfill. The only wood recovered and sold is about 800 tons/year of marketable logs. The other debris landfills I contacted did not give me estimates of total tonnage or of the percentage of wood entering the landfills. None of them recover any wood for recycling. One recycling company diverts about 1,000,000 tons/year of land clearing debris from landfills by charging lower tipping fees, and processes the wood and dirt into a full product line, as discussed below under Construction/Demolition Wood Wastes.

The amount of wood in the residential/commercial solid waste stream is probably somewhat lower than in other areas because of the relatively high rates of recycling noted in the Richmond-Petersburg area. If $3 \%$ of the approximately 1,000,000 tons/year of residential/commercial waste is wood, then about 30,000 tons/year of MSW wood may be entering landfills along with the trash. If $18 \%$ by weight (equivalent to about $50 \%$ by volume) of the approximately 424,000 tons/year of C/D and land clearing debris is wood, then about 76,000 tons/year of C/D wood may be entering landfills in the area.

\section{MSW Wood (Primarily Tree and Yard Wastes)}

As discussed above, an estimated 30,000 tons/year of MSW wood waste are included in the solid waste going to landfills in the area. (This only counts the wood that is in the locally generated solid waste. In fact, the amount of solid waste generated in other areas but disposed of in Richmond-Petersburg area landfills exceeds the amount generated locally.) All of the cities and counties in the Richmond-Petersburg metropolitan area have yard waste recycling programs that produce and give away mulch: an estimated 82,000 tons/year in all, according to the CVWMA. With one exception, none of the waste hauling companies I talked to in the Richmond-Petersburg area (BFI, USA Waste, Waste Management, and several others) do any wood separation or grinding. The one exception is USA Waste, which recovers and sells about 800 tons/year of saw logs.

The electric utility serving the Richmond-Petersburg metropolitan area is Virginia Power, which contracts primarily to Asplundh for tree trimming services. The Asplundh manager did not return my phone calls. Based on information from Asplundh and other utility tree service contractors in other areas, I estimate that a total of about 25 crews may be operating in the Richmond-Petersburg metropolitan area, producing an estimated 25,000 tons/year of mulch and firewood (assumed split: 6,000 firewood, 19,000 mulch). Almost all of this material is given away to land owners or to others who want it.

The Richmond and Petersburg Yellow Pages list 102 tree service companies (93 in the Richmond book, 9 others in the Petersburg book). I called about half of these companies, and based on that information I estimate that there are a total of about 120 crews operating in the metropolitan area, generating about 120,000 tons/year of wood from tree trimming and removals. Essentially all of this wood is given away or sold as mulch and firewood; my estimate is 30,000 tons/year of firewood and 90,000 tons/year of mulch. (A couple of companies mentioned taking some pine wood to landfills, and one mentioned recovering logs for sale to lumber mills.) Winter ice storms are the primary source of major tree 
damage in the Richmond area. The most recent one was in January 1994. The trees that sustain the most damage in these ice storms are the evergreens.

Table 16-2 summarizes the estimated resources of MSW wood in the Richmond-Petersburg metropolitan area. The total estimate, 257,000 tons/year (of which about 30,000 tons/year enter landfills), is equivalent to 0.297 tons/year/person based on the metropolitan area population of 865,640 . This is above the weighted average of 0.209 tons/year/person of MSW wood for the 30 cities, which range from 0.134 to 0.538 tons/year/person.

\section{Table 16-2 \\ Resource Estimate for MSW Wood in Richmond-Petersburg, Virginia Tons/year}

\begin{tabular}{|c|c|c|c|c|}
\hline & Mulch & Firewood & Landfill & Total \\
\hline Hauled with trash & & & 30,000 & 30,000 \\
\hline Municipal yard waste recycl. & 82,000 & & & 82,000 \\
\hline Utility tree trimming & 19,000 & 6,000 & & 25,000 \\
\hline Private tree service co's & 90,000 & 30,000 & & 120,000 \\
\hline Total & 191,000 & 36,000 & 30,000 & 257,000 \\
\hline
\end{tabular}

\section{Industrial Wood Wastes}

The Richmond and Petersburg Yellow Pages list 19 local companies under Pallets and Skids; two local companies under Trusses-Construction; 32 local companies under Lumber-Wholesale; 27 companies under Lumber-Retail; four furniture manufacturers; and 97 companies under Cabinet Makers or Furniture Designers \& Custom Builders (woodworking companies). Pallet wood recycling is a big business in the RichmondPetersburg metropolitan area, compared to most of the other metropolitan areas I have visited. Four large pallet companies (Interstate, Allied, Pioneer, and JC) generate a total of about 30,000 tons/year of pallet wood waste products. Six smaller companies generate a total of about 24,000 tons/year, and the remaining nine or so pallet companies probably generate a total of about 10,000 tons/year. Most of these companies declined to give estimates; my estimates are pieced together from information provided by one of the large pallet companies, a large wood recycler that services one of the large companies, most of the mid-sized companies, and others. My estimates of the amounts of products produced from pallet waste wood are approximately 40,000 tons/year of biomass fuel, 20,000 tons/year of mulch/compost, and 4,000 tons/year of animal bedding.

Interstate Pallet Company is a large, full-service pallet company that was recently acquired by PalEx, Inc., a publicly traded company that is acquiring the largest pallet companies in key markets. Interstate serves a large geographical region in the Southeast; its manager would not divulge any data. Biomass fuel is their primary wood waste product, because it is easy to market in the Richmond area, which has large pulp and paper plants. Pioneer Pallets Inc. sends 150 tons/week of wood waste to Environmental Contracting Company Inc. (ECC), who grinds pallet wood and sells biomass fuel to three paper companies in the area, and also sells mulch and compost. ECC charges a tipping fee of $\$ 250$ per trailer of pallet wood and boards, which is equivalent to about $\$ 42 /$ ton for an average load, or about $\$ 17 /$ ton for a large load. The Ledbetter landfill (a private landfill) charges a tipping fee of $\$ 350$ per flatbed truck for pallet wood. ECC processes on the order of 7,000-10,000 tons/year of pallet wood, producing biomass fuel and mulch. 
The current price for wood mulch around Richmond is about \$9-10/cubic yard, which is equivalent to about \$30-33/ton. (Higher quality mulch such as "double shredded hardwood mulch" sells for about \$17.50/cubic yard, and compost sells for about \$30/cubic yard.) The pulp and paper companies (Stone Container Corp., Bear Island Paper, and West Point Pulp and Paper) are currently paying about $\$ 9.00-9.50 /$ ton for biomass fuel from pallet wood, delivered. Stone Container Corp. has recently become a much smaller customer because it recently built a large wood processing yard, and now receives pallet wood and other wood wastes for a tipping fee, and generates its own fuel and pulp chips.

Wholesale lumber companies in the Richmond-Petersburg metropolitan area generate significant amounts of clean wood byproducts (wood chips and sawdust) that they sell to local pulp and paper companies for pulp chips and biomass fuel, respectively. Some of the lumber companies sell bark for mulch, and some sell sawdust as animal bedding rather than fuel. Of the 32 wholesale lumber companies listed in the Yellow Pages, I found 13 that produce significant amounts of wood residue byproducts. The estimates I obtained from those 13 lumber companies are summarized below:

\begin{tabular}{lr} 
Wood chips sold for pulp & 108,000 tons/year \\
Sawdust sold for fuel & 52,000 \\
Sawdust sold for animal bedding & 8,000 \\
Bark sold for mulch & 12,000 \\
\cline { 2 - 2 } Total & 180,000 tons/year
\end{tabular}

The 27 retail lumber companies in the Richmond-Petersburg area use or give away about 500 tons/year of waste wood as firewood, or in a few cases as animal bedding. The 97 woodworking companies (cabinet and custom furniture makers) in the area are all very small companies that generate a total of 500 tons/year or less of firewood.

Table 16-3 summarizes the estimated resources of industrial wood wastes in the RichmondPetersburg metropolitan area. The total estimate of 245,000 tons/year is equivalent to about 0.283 tons/year/person based on the Richmond-Petersburg metropolitan area population of 865,640 . This is the second-highest estimate found in the 30-city survey for pallet wood wastes (which range from 0.000 to 0.104 and average 0.042 tons/year/person).

Table 16-3

\section{Resource Estimate for Industrial Wood Wastes in Richmond-Petersburg, Virginia Tons/year}

\begin{tabular}{|c|c|c|c|c|c|c|}
\hline & $\begin{array}{l}\text { Pulp } \\
\text { Chips }\end{array}$ & Biofuel & $\begin{array}{l}\text { Animal } \\
\text { Beddin }\end{array}$ & Mulch & $\begin{array}{l}\text { Fire- } \\
\text { wood }\end{array}$ & Total \\
\hline Pallet companies & & 40,000 & 4,000 & 20,000 & & 64,000 \\
\hline Whlsl lumber co's & 108,000 & 52,000 & 8,000 & 12,000 & & 180,000 \\
\hline Retail lumber co's & & & & & 500 & 500 \\
\hline Woodwrking co's & & & & & 500 & 500 \\
\hline Total & 108,000 & 92,000 & 12,000 & 32,000 & 1,000 & 245,000 \\
\hline
\end{tabular}




\section{Construction/Demolition Wood Wastes}

As discussed in the subsection above on MSW Collection and Disposal, an estimated 76,000 tons/year of C/D wood waste are included in the solid waste going to landfills in the area. One C/D landfill, the Ashcake Road Landfill, has separate tipping fees for C/D debris, stumps and wood, concrete and asphalt, clean dirt, and pallets. They grind wood and sell mulch, but I was unable to get estimates of quantities. The tipping fees for stumps and wood range up to $\$ 140$ for a 26 foot trailer; for pallets, $\$ 350$ per flatbed truck.

The Yellow Pages list 31 local companies under Demolition Contractors and four companies under Land Clearing \& Leveling. Most of the debris these companies generate goes to debris landfills or to East Coast Wood Recycling, Inc. Salvageable logs are sold to sawmills, and some wood is cut up for firewood.

East Coast Wood Recycling, Inc. processes land clearing debris into a full product line, including saw logs, pulp chips, biomass fuel, mulch, bulking agent for sewage sludge, compost, and topsoil. Tipping fees are charged by the size of the truck, ranging from $\$ 30$ for a truck under 8 feet long up to $\$ 140$ for a truck 26 feet long. (These are roughly equivalent to $\$ 5 /$ cubic yard, which is equivalent to about $\$ 5 /$ ton for dirt and about $\$ 15 /$ ton for wood. The USA Waste Qualla Road debris landfill charges $\$ 8.50$ /cubic yard for debris and $\$ 6.50$ /cubic yard for stumps and brush.) The owner estimated that he processed about $1,000,000$ tons/year of land clearing debris last year. He sold about 20,000 tons/year of boiler fuel to three paper companies. I did not get estimates of the amounts of wood he sold in the form of saw logs, pulp chips, mulch, bulking agent, or compost. Assuming $50 \%$ wood by volume in the incoming material, which is equivalent to about $18 \%$ wood by weight, results in an estimate of about 180,000 tons/year of wood. Assuming about 80\% recovery of wood into salable products, the estimated total production of recycled wood materials by East Coast Wood Recycling, Inc. is about 140,000 tons/year. My guess is that about 20,000 tons/year went to saw $\operatorname{logs}, 20,000$ tons/year to pulp chips, 20,000 to biomass fuel, and the remainder (about 80,000 tons/year) went to mulch/compost.

To summarize, the following quantities of wood are estimated for the construction/demolition and land clearing category in the Richmond-Petersburg metropolitan area:

\begin{tabular}{ll} 
Wood to landfills & 76,000 tons/year \\
Biomass fuel & 20,000 \\
Saw logs & 20,000 \\
Pulp chips & 20,000 \\
Mulch & 80,000 \\
\cline { 2 - 2 }$\quad$ Total & 216,000 tons/year
\end{tabular}

The estimated total of 216,000 tons/year is equivalent to 0.250 tons/year/person based on the Richmond-Petersburg metropolitan area population of 865,640. This is the highest of the per capita $C / D$ wood estimates found in the 30 -city survey, which range from 0.015 to 0.250 and average 0.076 tons/year/person. 


\section{Supply Curve}

Figure 16-1 shows the supply curve for urban wood wastes in the Richmond-Petersburg area. Table 16-4 shows the data and assumptions used to produce the supply curve.

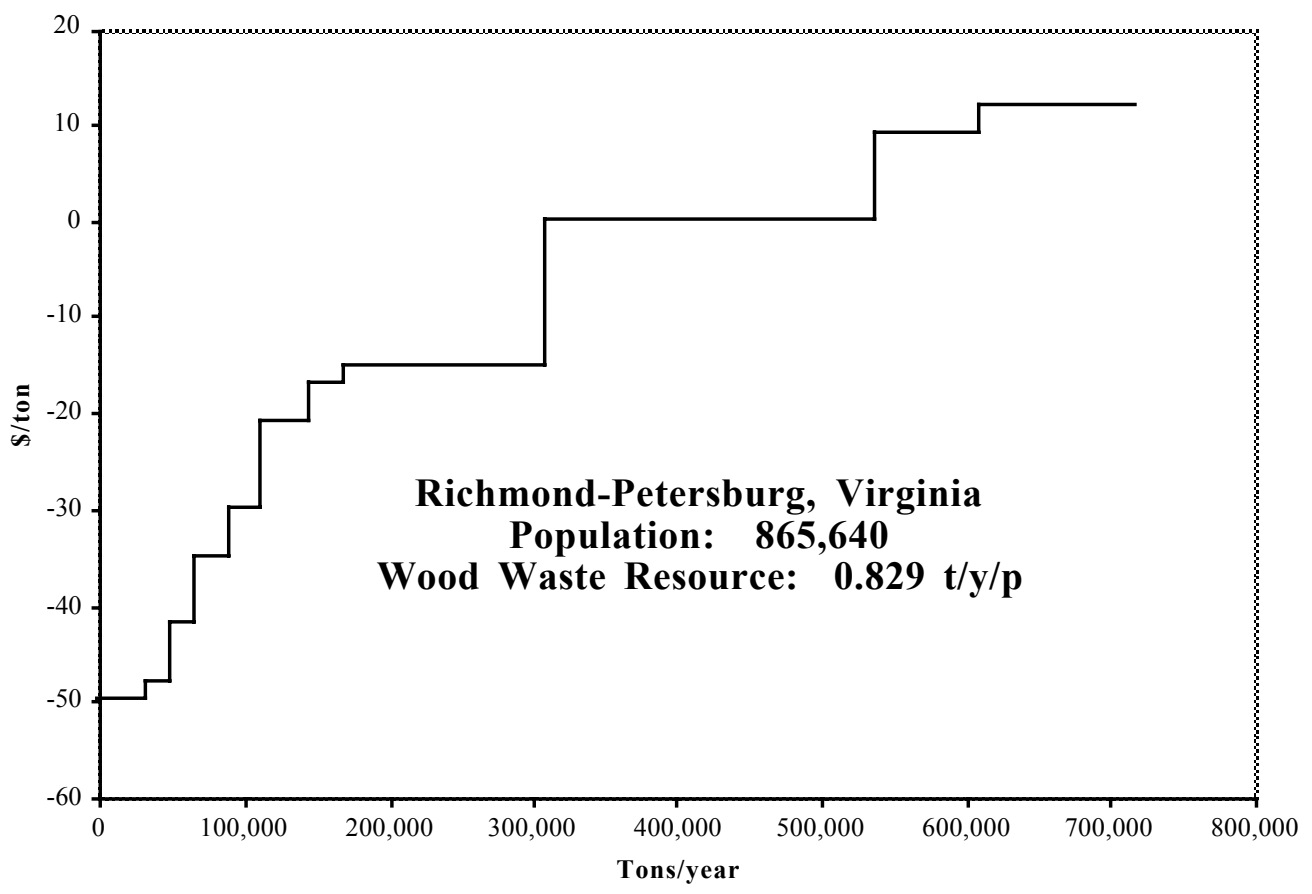

Figure 16-1. Supply Curve for Urban Wood Wastes in Richmond-Petersburg, Virginia

Table 16-4

Data and Assumptions Used in Supply Curve for Richmond-Petersburg

Tons/year Cumulative $\frac{\$ / \text { ton }}{34,000}$

\begin{tabular}{|c|c|c|c|}
\hline 34,000 & 34,000 & -50 & Landfilled with MSW and C/D - public landfills \\
\hline 15,000 & 49,000 & -48 & Landfilled with MSW and C/D - private landfills \\
\hline 18,000 & 67,000 & -42 & Pallet wood processors - biofuel, animal bd, mulch \\
\hline 24,000 & 91,000 & -35 & Landfilled with MSW and C/D - private landfills \\
\hline 20,000 & 111,000 & -30 & Pallet wood processors - biofuel, animal bd, mulch \\
\hline 33,000 & 144,000 & -21 & Landfilled with MSW and C/D - private landfills \\
\hline 26,000 & 170,000 & -17 & Pallet wood processors - biofuel, animal bd, mulch \\
\hline 140,000 & 310,000 & -15 & Land clearing wood processors - fuel, logs, chips, \\
\hline 228,000 & 538,000 & 0 & Firewood and mulch - given away \\
\hline 72,000 & 610,000 & 9 & Biofuel, animal bedding, mulch - sold \\
\hline 108,000 & 718,000 & 12 & Pulp chips - sold \\
\hline
\end{tabular}


Danville is on the Dan River, just north of North Carolina on Virginia's southern border, approximately midway between the eastern and western ends of the state. Nearby cities include Greensboro, North Carolina (about 30 miles south) and Lynchburg, Virginia (about 60 miles north). Danville is in Pittsylvania County. Caswell County, North Carolina is just across the river.

Table 17-1 summarizes the data collected on urban wood resources in the Danville area. The estimated total urban wood waste resource, 0.727 tons/year/person, is well above the weighted average of 0.333 tons/year/person for the 30 metropolitan areas surveyed; the range for the 30 cities is from 0.156 to 0.829 tons/year/person. The Danville metropolitan area has a good yard and tree waste recycling program, run by the city. Two local wholesale lumber companies produce a significant amount of industrial wood wastes (byproducts, really). The large forest products industry in the area provides a ready market for the saw logs, pulp chips, and biomass fuel produced from these operations.

Table 17-1

Resource Estimate for Urban Wood Waste in Danville, Virginia

\begin{tabular}{|c|c|c|c|c|c|}
\hline \multirow[b]{2}{*}{ Use or Disposal Method: } & \multicolumn{4}{|c|}{ Tons/Year } & \multirow[b]{2}{*}{$\begin{array}{c}\text { Price } \\
\text { \$/ton }\end{array}$} \\
\hline & $\begin{array}{l}\text { MSW } \\
\text { Wood }\end{array}$ & $\begin{array}{l}\text { Industr. } \\
\text { Wood }\end{array}$ & $\begin{array}{c}\text { C/D } \\
\text { Wood }\end{array}$ & Total & \\
\hline Pulp chips & & 27,000 & & 27,000 & 12 \\
\hline Biomass fuel & & 18,000 & & 18,000 & 9 \\
\hline Mulch (ground cover) & 11,000 & 3,000 & & 14,000 & 9 to 0 \\
\hline Animal bedding & & 5,000 & & 5,000 & 9 to 0 \\
\hline Firewood & 1,000 & & & 1,000 & 0 \\
\hline Saw logs & & & 1,000 & 1,000 & -15 \\
\hline Landfill or rural dumping* & 6,000 & & 7,000 & 13,000 & 0 to -38 \\
\hline Total & 18,000 & 53,000 & 8,000 & 79,000 & \\
\hline Total, tons/year/person & 0.166 & 0.488 & 0.074 & 0.727 & \\
\hline
\end{tabular}

* Rural dumping includes burning (common in this area).

\section{Municipal Solid Waste (MSW) Collection and Disposal}

The City of Danville collects about 30,000 tons/year of solid waste (residential trash, bulk wastes, yard wastes, and commercial solid waste). About 10,000 tons/year of this material is yard waste and brush that is ground to mulch and/or composted by the city. All of the mulch and compost is given away to local residents. The city delivers the remainder of the solid waste to a Waste Management, Inc. transfer station in Danville. Waste Management, Inc. transports the solid waste to its landfill in Kernersville, North Carolina (near WinstonSalem, about 50 miles southwest of Danville). The landfill tipping fee is about \$38/ton.

Pittsylvania County (in the rural area outside Danville city limits) has drop-off sites where people take their trash. The Pittsylvania County landfill receives about 42,000 tons/year of solid waste. The county does not have a yard waste or wood waste recycling program. Most of the wood wastes (brush, etc.) in the rural areas get burned rather than collected. 
If we use 62,000 tons/year as the total solid waste in the Danville metropolitan area going to landfills, and assume that this waste contains about 3\% wood, then about 2,000 tons/year of wood wastes are included in the solid waste entering landfills.

\section{MSW Wood (Primarily Tree and Yard Wastes)}

As discussed in the subsection above, an estimated 2,000 tons/year of MSW wood waste are included in the solid waste going to landfills in the area. The Danville yard waste recycling program produces and gives away an estimated 10,000 tons/year of mulch and compost. Neither of the waste hauling companies I talked to in the Danville area (First Piedmont Corp. and Waste Management, Inc.) do any wood separation or grinding.

The City of Danville Department of Power \& Light has a tree trimming crew that hauls the wood it generates to the city yard waste mulch and compost facility. This wood is included in the 10,000 tons/year estimate discussed above.

The Danville Yellow Pages list five tree service companies. I called all of these companies, and based on that information I estimate that there are a total of about six crews operating in the metropolitan area, generating about 6,000 tons/year of wood from tree trimming and removals. Some of this wood is given away or sold as mulch and firewood; my estimate is 1,000 tons/year of firewood and 1,000 tons/year of mulch. The remainder, about 4,000 tons/year, is disposed of on private rural land either by dumping in gullies or by burning.

Table 17-2 summarizes the estimated resources of MSW wood in the Danville metropolitan area. The total estimate, 18,000 tons/year (of which about 6,000 tons/year enter landfills or are dumped or burned in rural areas), is equivalent to 0.166 tons/year/person based on the Danville metropolitan area population of 108,711. This is below the weighted average of 0.209 tons/year/person of MSW wood for the 30 metropolitan areas, which range from 0.134 to 0.538 tons/year/person.

Table 17-2

Resource Estimate for MSW Wood in Danville, Virginia Tons/year

\begin{tabular}{|c|c|c|c|c|}
\hline & Mulch & Firewood & Landfill* & Total \\
\hline Hauled with trash & & & 2,000 & 2,000 \\
\hline Municipal yard waste recycl. & 10,000 & & & 10,000 \\
\hline Utility tree trimming & included & & & \\
\hline Private tree service co's & 1,000 & 1,000 & 4,000 & 6,000 \\
\hline Total & 11,000 & 1,000 & 6,000 & 18,000 \\
\hline
\end{tabular}

\section{Industrial Wood Wastes}

The Danville Yellow Pages list no local companies under Pallets and Skids; one local company under Trusses-Construction; three local companies under Lumber-Wholesale; three companies under Lumber-Retail; and 11 companies under Cabinet Makers or Furniture Designers \& Custom Builders (woodworking companies). Wholesale lumber companies in the Danville metropolitan area sell most of their wood byproducts (wood chips and sawdust) to local pulp and paper companies for pulp chips and biomass fuel, respectively. Some of the lumber companies sell bark for mulch, and some sell sawdust as 
animal bedding rather than fuel. The estimates I obtained from the three lumber companies in the Danville area are summarized below:

\begin{tabular}{lr} 
Wood chips sold for pulp & 27,000 tons/year \\
Sawdust sold for fuel & 18,000 \\
Shavings sold for animal bedding & 5,000 \\
Bark sold for mulch & 3,000 \\
\cline { 2 - 2 } Total & 53,000 tons/year
\end{tabular}

One of the three retail lumber companies in the Danville area burns small quantities of waste wood. The other two companies do no cutting and produce essentially no wood wastes. The 11 woodworking companies (cabinet and custom furniture makers) in the Danville area are all very small companies. They produce very small amounts of wood scraps that are used by family and friends, and/or given away as firewood. My estimate for the total amount of wood generated by these companies is 100 tons/year or less.

Table 17-3 summarizes the estimated resources of industrial wood wastes in the Danville metropolitan area. The total estimate of 53,000 tons/year is equivalent to about 0.488 tons/year/person based on the Danville metropolitan area population of 108,711. This is the highest per capita estimate of industrial wood waste for the 30 metropolitan areas surveyed; the range is from 0.001 to 0.488 , and the average is 0.048 tons/year/person.

Table 17-3

Resource Estimate for Industrial Wood Wastes in Danville, Virginia
Tons/year

\begin{tabular}{|c|c|c|c|c|c|}
\hline & $\begin{array}{l}\text { Pulp } \\
\text { Chips }\end{array}$ & $\begin{array}{c}\text { Biomass } \\
\text { Fuel }\end{array}$ & $\underset{\text { Beddin }}{\text { Animal }}$ & Mulch & Total \\
\hline $\begin{array}{l}\text { Pallet companies } \\
\text { Wholesale lumber co's } \\
\text { Woodworking co's }\end{array}$ & 27,000 & $\begin{array}{r}18,000 \\
<100\end{array}$ & 5,000 & 3,000 & $\begin{array}{r}53,000 \\
<100\end{array}$ \\
\hline Total & 27,000 & 18,000 & 5,000 & 3,000 & 53,000 \\
\hline
\end{tabular}

\section{Construction/Demolition Wood Wastes}

I obtained no information about C/D landfills in the Danville area. The Danville Yellow Pages list one local company under Demolition Contractors and two companies under Land Clearing \& Leveling. Salvageable logs are sold to sawmills, and some wood is cut up for firewood. Any wood that does not produce revenues is burned with a permit. I was unable to get quantitative estimates.

My estimated total of 8,000 tons/year of $\mathrm{C} / \mathrm{D}$ wood wastes is equivalent to 0.075 tons/year/person based on the Danville metropolitan area population of 108,711. This is very close to the weighted average of 0.076 tons/year/person of $C / D$ wood for the 30 metropolitan areas surveyed; the range is from 0.015 to 0.250 tons/year/person. 


\section{Supply Curve}

Figure 17-1 shows the supply curve for urban wood wastes in the Danville area. Table 174 shows the data and assumptions used to produce the supply curve.

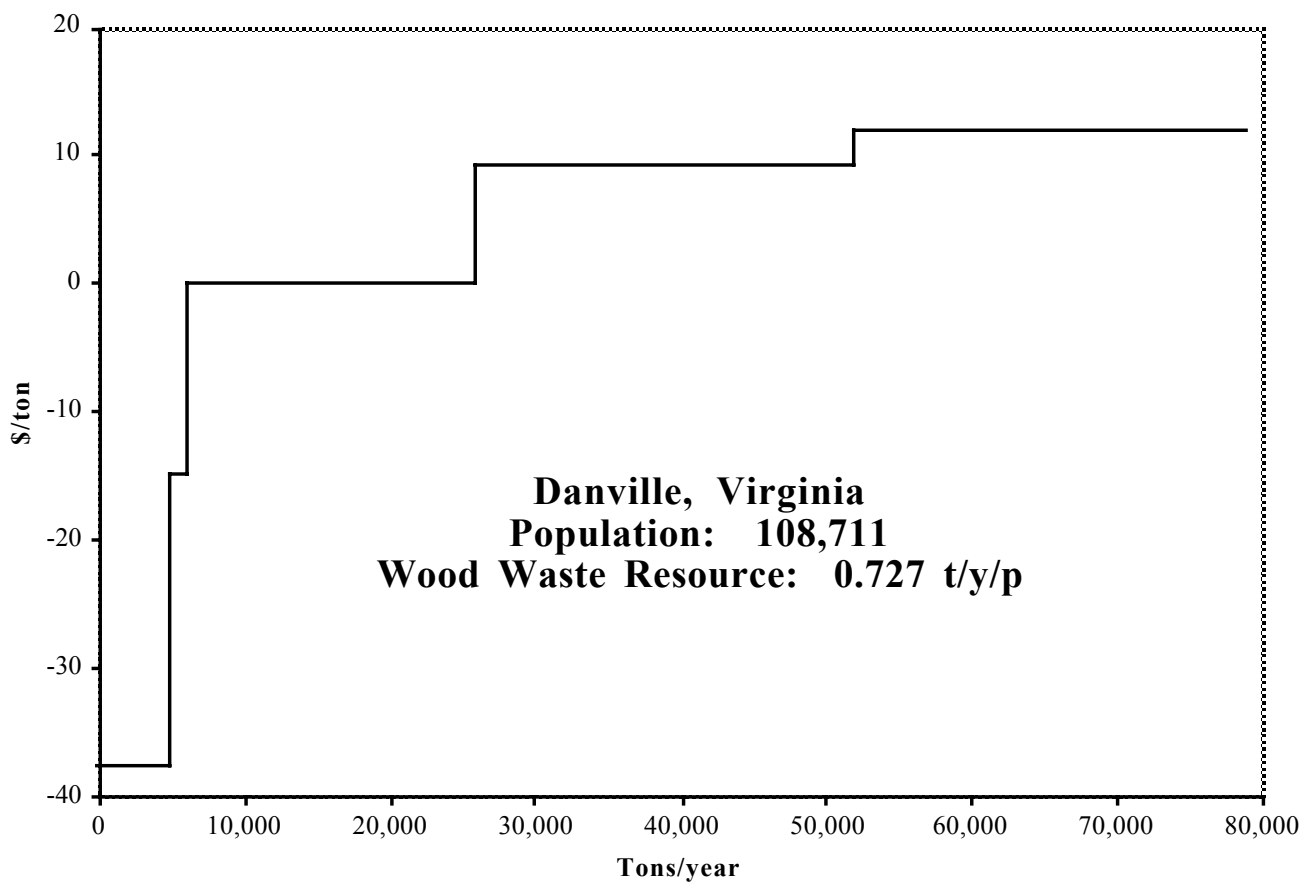

Figure 17-1. Supply Curve for Urban Wood Wastes in Danville, Virginia

Table 17-4

Data and Assumptions Used in Supply Curve for Danville

Tons/year Cumulative \$/ton

5,000

1,000

8,000

12,000

26,000

27,000

\section{5,000}

6,000

14,000

26,000

52,000

79,000

\section{Assumptions/Comments}

-38 Landfilled with MSW and C/D

-15 Land clearing wood processors - saw logs

0 Rural dumping and burning

0 Firewood, mulch and animal bedding - given away

9 Biofuel, animal bedding, mulch - sold

12 Pulp chips - sold 
Fayetteville, an inland port on the Cape Fear River, is in the center of Cumberland County. There are no other large towns in the county; county data are equivalent to data on the Fayetteville metropolitan area. I made no attempt to collect data from Fort Bragg or Pope Air Force Base. I am not sure whether the population figure cited by the US Bureau of the Census includes the population of the military personnel and families living on those bases.

Table 18-1 summarizes the data collected on urban wood resources in the Fayetteville area. The estimated total urban wood waste resource, 0.322 tons/year/person, is just below the weighted average of 0.333 tons/year/person for the 30 metropolitan areas surveyed; the range for the 30 cities is from 0.156 to 0.829 tons/year/person. The Fayetteville metropolitan area has a good yard and tree waste recycling program, run by the city and county. The forest products industry in the area (within about a 100 mile radius) provides a reasonably good market for saw logs and biomass fuel. If a biomass energy project were developed in the Fayetteville area, it could capture the 19,000 tons/year of biomass fuel now being transported up to 100 miles away. In addition, a local biomass energy project might be able to extract another 30,000-60,000 tons/year of wood from the MSW and C/D wood streams at a relatively low cost, and produce 3-8 MW of electricity.

Table 18-1

Resource Estimate for Urban Wood Waste in Fayetteville, North Carolina

\begin{tabular}{|c|c|c|c|c|c|}
\hline \multirow[b]{2}{*}{ Use or Disposal Method: } & \multicolumn{4}{|c|}{ Tons/Year } & \multirow[b]{2}{*}{$\begin{array}{c}\text { Price, } \\
\text { \$/ton }\end{array}$} \\
\hline & $\begin{array}{l}\text { MSW } \\
\text { Wood }\end{array}$ & $\begin{array}{l}\text { Industr. } \\
\text { Wood }\end{array}$ & $\begin{array}{c}\text { C/D } \\
\text { Wood }\end{array}$ & Total & \\
\hline Saw logs & & & 2,600 & 2,600 & 0 \\
\hline Biomass fuel & 13,300 & 5,600 & & 18,900 & 0 \\
\hline Firewood & 6,000 & 300 & & 6,300 & 0 \\
\hline Mulch & 20,700 & & & 20,700 & 0 \\
\hline Animal bedding & & 100 & & 100 & 0 \\
\hline Landfill or rural dumping* & 21,600 & 100 & 18,000 & 39,700 & 0 to -38 \\
\hline Total & 61,600 & 6,100 & 20,600 & 88,300 & \\
\hline Total, tons/year/person & 0.224 & 0.022 & 0.075 & 0.322 & \\
\hline
\end{tabular}

*Rural dumping includes private rural disposal or burning (common in this area).

\section{Municipal Solid Waste (MSW) Collection and Disposal}

The City of Fayetteville, Cumberland County, and other haulers in the metropolitan area collect about 243,000 tons/year of solid waste (residential trash, bulk wastes, yard wastes, commercial and industrial solid waste, and rubble). About 211,000 tons/year of this solid waste go to the Ann Street sanitary landfill (owned by the county, and located on the outskirts of Fayetteville). A county solid transfer station and rubble landfill on Wilkes Road accepts about 32,000 tons/year of inert rubble, wood and yard wastes, and tires. The tipping fee is currently $\$ 37 /$ ton. Most of the wood received or separated at the Wilkes Road facility is ground to boiler fuel and mulch, and given away. Some wood (e.g., large spools, or pieces of lumber attached to metal) is burned in a pit burner. The following is a summary of solid wastes received and shipped from these two facilities in 1997: 
$\frac{\text { Wilkes Road Facility }}{\text { Incoming material: }}$

MSW wood

Industrial wood

Rubble

Tires

Total incoming

Outgoing material:

\begin{tabular}{lr} 
Biomass fuel & 13,300 \\
Mulch & 8,736 \\
\cline { 2 - 2 } Total outgoing & 22,036
\end{tabular}

Ann Street Sanitary Landfill

Incoming material:

MSW wood

Industrial wood

C/D wood

tons/year

7,414

84

62

Mulch (alternate daily cover) $\quad 12,842$

Rubble

1,433

All other solid waste

189,023

Total incoming

210,858

The data above show that the total amount of solid waste received at both facilities is about 243,000 tons/year. Subtracting the 22,000 tons/year of ground wood shipped from the Wilkes Road facility, the total solid waste disposed of is about 221,000 tons/year. The mulch that is used at the Ann St. landfill for alternate daily cover is the product of debris cleaned up after Hurricane Fran came through the area in the fall of 1996. The debris ("mulch") contains at least 50\% dirt, and I have not counted it in the estimated amount of wood disposed of in the landfill along with the garbage (or burned at the Wilkes Road facility). My estimates (derived from the above data) of the amounts of wood disposed of in these ways are about 11,600 tons/year of MSW wood, 100 tons/year of industrial wood, and 500 tons/year of C/D wood.

The 13,300 tons of biomass fuel listed above were sent primarily to Stone Container Corp. mills in Florence, South Carolina and Regalwood, North Carolina. Stone Container pays only the trucking cost, which I estimate to be on the order of $\$ 10 /$ ton; Cumberland County does not charge for the wood. In addition, about 8,700 tons/year of mulch were given away from the Cumberland County Wilkes Road facility to the general public.

\section{MSW Wood (Primarily Tree and Yard Wastes)}

As discussed in the subsection above, an estimated 11,600 tons/year of MSW wood waste are included in the solid waste going to landfills in the area. The Cumberland County wood waste recycling program produces and gives away an estimated 13,300 tons/year of boiler fuel, and an estimated 8,700 tons/year of mulch. None of the waste hauling companies I talked to in the Fayetteville area (including Waste Industries Inc. and Waste Management of Central North Carolina) do any wood separation or grinding.

Carolina Power \& Light Company Provides electric service to Fayetteville, and throughout North and South Carolina. Their switchboard operator transferred me directly to Asplundh Tree Service Company, who did not return my calls. Two other utilities in the area are Lumbee River Electric Membership Corp. and South River Electric Membership Corp. One of them uses Bartlett Tree Service as their primary tree trimming contractor; I did not get information from the other. Based on information gathered from Asplundh, Bartlett, and utilities in other areas, I estimate that about 8,000 tons/year of wood are generated by utility tree trimming operations in the Fayetteville area. About 2,000 tons/year of this wood are given away as firewood, and the remainder is given away as mulch.

The Fayetteville Yellow Pages list 24 tree service companies. I found that seven of them were no longer in business. Based on information from the eight tree service companies I did talk to, I estimate that about 20 crews operate in the metropolitan area, generating about 
20,000 tons/year of wood from tree trimming and removals. About 4,000 tons/year of firewood and 6,000 tons/year of mulch are given away as mulch and firewood. About 10,000 tons/year are disposed of at the county rubble fill for $\$ 37 /$ ton, or (in most cases) at private rubble landfills for much lower tipping fees on the order of $\$ 10 /$ ton.

Table 18-2 summarizes the estimated resources of MSW wood in the Fayetteville area. The total estimate, 61,600 tons/year (of which about 21,600 tons/year enter landfills or are dumped or burned in rural areas), is equivalent to 0.224 tons/year/person based on the Fayetteville metropolitan area population of 274,566. This is above the weighted average of 0.209 tons/year/person of MSW wood for the 30 metropolitan areas, which range from 0.134 to 0.538 tons/year/person.

\section{Table 18-2 \\ Resource Estimate for MSW Wood in Fayetteville, North Carolina Tons/year}

\begin{tabular}{|c|c|c|c|c|c|}
\hline & Biofuel & Mulch & $\begin{array}{l}\text { Fire- } \\
\text { wood }\end{array}$ & $\begin{array}{l}\text { Land- } \\
\text { fill* }\end{array}$ & Total \\
\hline Hauled with trash & & & & 11,600 & 11,600 \\
\hline Municipal yard waste recycl. & 13,300 & 8,700 & & & 22,000 \\
\hline Utility tree trimming & & 6,000 & 2,000 & & 8,000 \\
\hline Private tree service co's & & 6,000 & 4,000 & 10,000 & 20,000 \\
\hline Total & 13,300 & 20,700 & 6,000 & 21,600 & 61,600 \\
\hline
\end{tabular}

*“Landfill” includes rural dumping and burning.

\section{Industrial Wood Wastes}

The Fayetteville Yellow Pages list three local companies under Pallets and Skids; two local companies under Trusses-Construction; no local companies under Lumber-Wholesale; five companies under Lumber-Retail; and 16 companies under Cabinet Makers or Furniture Designers \& Custom Builders (woodworking companies). The pallet companies in the Fayetteville area grind their wood waste and sell most of it (at least 5,000 tons/year) as boiler fuel to pulp and paper companies in Florence, South Carolina and New Bern, North Carolina. The truss companies in the Fayetteville area produce very small amounts of waste wood, and consume them on site as fuel.

Two of the retail lumber companies in the Fayetteville area generate small quantities of waste wood. About 100 tons/year of sawdust go to animal bedding; 100 tons/year of sawdust go to the landfill; and about 200 tons/year of small pieces of wood get used as firewood or kindling. The other retail lumber companies in the area do no cutting and produce essentially no wood wastes. The 16 woodworking companies (cabinet and custom furniture makers) in the Fayetteville area are all very small companies. They produce about 200 tons/year of wood scraps that are hauled to the landfill, used by family and friends, and/or given away as firewood.

As discussed above under MSW Collection and Disposal, about 700 tons/year of industrial waste are identified in the landfill records. I have assumed that 200 tons/year of this industrial waste originate from the retail lumber companies and woodworking companies I interviewed, and that another 500 tons/year originate from companies I did not interview. I 
also have assumed that about 100 of the 700 tons/year actually end up in the landfill, and that about 600 tons/year are ground at the landfill and sold as boiler fuel.

Table 18-3 summarizes the estimated resources of industrial wood wastes in the Fayetteville metropolitan area. The total estimate of 6,100 tons/year is equivalent to about 0.022 tons/year/person based on the Fayetteville metropolitan area population of 274,566. This is below the weighted average of 0.048 tons/year/person of industrial wood waste for the 30 metropolitan areas surveyed; the range is from 0.001 to 0.488 tons/year/person.

\section{Table 18-3 \\ Resource Estimate for Industrial Wood Wastes in Fayetteville, North Carolina Tons/year}

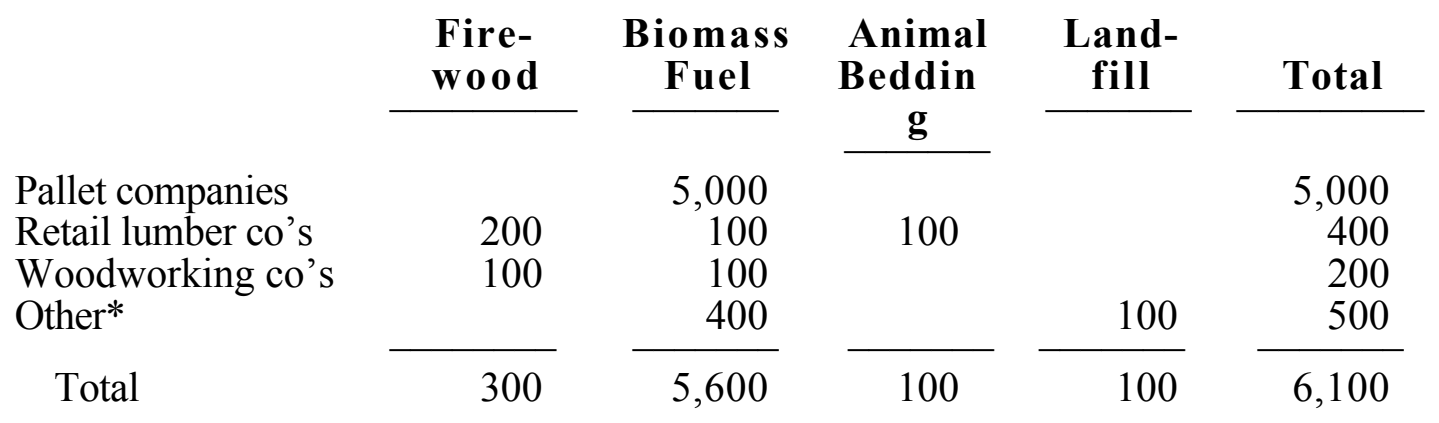

* "Other" refers to industrial wood wastes in the landfill records from sources I did not identify.

\section{Construction/Demolition Wood Wastes}

There are several private rubble landfills in the Fayetteville area that charge much lower tipping fees than the county landfill (less than $\$ 20 /$ ton versus $\$ 37 /$ ton). I did not obtain statistics on the amounts of $\mathrm{C} / \mathrm{D}$ and land clearing wastes disposed of at these private rubble landfills, but nearly all of the $\mathrm{C} / \mathrm{D}$ and land clearing contractors I interviewed said they took at least part of their wastes to these landfills.

The Fayetteville Yellow Pages list nine local companies under Demolition Contractors and seven companies under Land Clearing \& Leveling. Salvageable logs are sold to sawmills, and some wood is cut up for firewood. Any wood that does not produce revenues is burned with a permit. Other options available, depending on the location of the site (e.g., rural vs. urban) and the land owner's wishes, include grinding the wood and using it on site for landscaping, or hauling it to rural locations to fill gullies. One company has its own landfill. I was unable to get quantitative estimates.

My estimated total of 20,600 tons/year of C/D wood wastes is equivalent to 0.075 tons/year/person based on the Fayetteville metropolitan area population of 274,566. This is very close to the weighted average of 0.076 tons/year/person of $C / D$ wood for the 30 metropolitan areas surveyed; the range is from 0.015 to 0.250 tons/year/person. 


\section{Supply Curve}

Figure 18-1 shows the supply curve for urban wood wastes in the Fayetteville area. Table 18-4 shows the data and assumptions used to produce the supply curve.

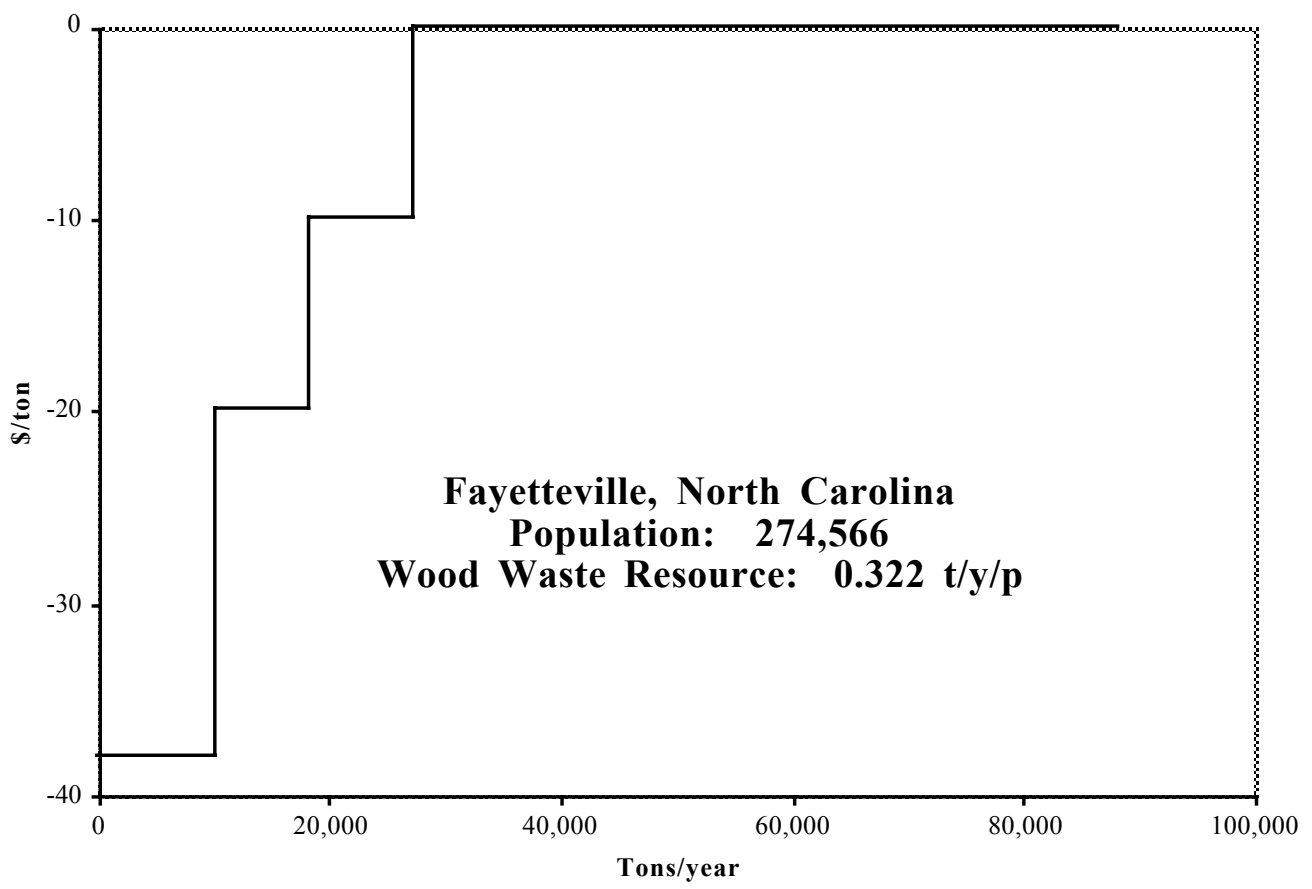

Figure 18-1. Supply Curve for Urban Wood Wastes in Fayetteville, North Carolina

Table 18-4

Data and Assumptions Used in Supply Curve for Fayetteville

$\underline{\text { Tons/year }}$ Cumulative $\frac{\text { \$/ton }}{10,100}$

10,100

$10,100-38$

Assumptions/Comments

$8,000 \quad 18,100 \quad-20 \quad$ Landfilled - private rubble landfills

$9,000 \quad 27,100 \quad-10 \quad$ Landfilled - private rubble landfills

$48,200 \quad 75,300 \quad 0 \quad$ Firewood, mulch, animal bd, fuel, logs - given away

$13,000 \quad 88,300 \quad 0 \quad$ Rural dumping and burning 
Florence has been an important junction of two railroad systems since the 1850s, and is a retail and wholesale distribution center. Florence is located on I-95, near the Great Pee Dee River. The counties of Florence and Darlington can be considered equivalent to the Florence metropolitan area. Stone Container Corp. operates a major containerboard plant in Florence and buys about 450,000 tons/year of wood wastes for fuel from throughout a 100-mile radius -- but none of the wood wastes bought by Stone Container come from Florence itself. The City of Florence does recycle yard and tree wastes, mixing the mulch with sewage sludge and composting the mixture.

Table 19-1 summarizes the data collected on urban wood resources in the Florence area. The estimated total urban wood waste resource, 0.273 tons/year/person, is below the weighted average of 0.333 tons/year/person for the 30 metropolitan areas surveyed; the range for the 30 cities is from 0.156 to 0.829 tons/year/person. A local biomass energy project might be able to extract about 10,000-20,000 tons/year of wood from the MSW and $\mathrm{C} / \mathrm{D}$ wood streams at a relatively low cost, and produce 1-2 MW of electricity.

Table 19-1

Resource Estimate for Urban Wood Waste in Florence, South Carolina

\begin{tabular}{|c|c|c|c|c|c|}
\hline \multirow[b]{2}{*}{ Use or Disposal Method: } & \multicolumn{4}{|c|}{ Tons/Year } & \multirow[b]{2}{*}{$\begin{array}{c}\text { Price, } \\
\$ / \text { ton } \\
\end{array}$} \\
\hline & $\begin{array}{l}\text { MSW } \\
\text { Wood }\end{array}$ & $\begin{array}{c}\text { Industr. } \\
\text { Wood }\end{array}$ & $\begin{array}{c}\text { C/D } \\
\text { Wood }\end{array}$ & Total & \\
\hline Firewood & 3,000 & & & 3,000 & 0 \\
\hline Mulch & 11,200 & & & 11,200 & 0 \\
\hline Landfill & 11,000 & 4,000 & 2,000 & 17,000 & -28 to -30 \\
\hline Total & 25,200 & 4,000 & 2,000 & 31,200 & \\
\hline Total, tons/year/person & 0.220 & 0.035 & 0.017 & 0.273 & \\
\hline
\end{tabular}

\section{Municipal Solid Waste (MSW) Collection and Disposal}

According to data from the South Carolina Department of Health and Environmental Control (DHEC), the total amount of C/D debris disposed of in Florence and Darlington counties in fiscal year 1997 (July 1996 - June 1997) was about 16,300 tons/year. Florence County generated about 43,100 tons/year of MSW in FY97, plus about 71,700 tons/year of industrial solid waste and about 2,000 tons/year of $\mathrm{C} / \mathrm{D}$ and land clearing debris. Florence County recycled about 5,200 tons/year of yard waste in FY97. The City of Florence collected about 3,500-3,900 tons/year of yard waste during the last several years. Hurricane Fran in the fall of 1996 caused FY97 to be a somewhat higher than normal year. The city grinds the wood and mixes the wood and leaves with sewage sludge to make compost, which is used in city landscaping and given away to the public.

Trash collected in the City of Florence and most of the surrounding area is brought to the American Refuse Transfer Station owned by ARS/Waste Management, who compacts and hauls the solid waste from there to a private landfill in Lee County (30 or 40 miles west of Florence). The ARS/Waste Management manager said they haul about 79,000 tons/year. (Comparing this with the data in the DHEC Annual Report, I assume that this is a mixture of municipal and industrial wastes, and that other trash haulers take trash to other facilities besides the transfer station.) The transfer station charges a tipping fee of $\$ 28.50 /$ ton; the tipping fee at the landfill in Lee County is in the same range (\$28-30/ton). There is no 
wood separation or grinding at the transfer station. ARS/Waste Management has recently acquired two mobile wood grinding machines for use in the region, but these machines have not yet been to Florence.

The Florence County landfill is a C/D landfill that charges an average tipping fee of about $\$ 60$ per 20 cubic yard container. (Assuming a full container, this is equivalent to about $\$ 10 /$ ton of wood or about $\$ 3 /$ ton of dirt or concrete) The landfill manager estimated that they received about 19,000 tons of debris in calendar year 1997, and that about half of that was yard and wood waste. The other half was about equally split between C/D debris and land clearing debris, which he guesstimated was about $50 \%$ wood by volume (about $20 \%$ wood by weight). Thus, the Florence County C/D landfill received about 9,000 tons/year of MSW wood, and about 2,000 tons/year of C/D and land clearing wood waste.

Based on all of the information collected, I estimate that the total solid waste stream in the Florence metropolitan area consists of about 43,000 tons/year of MSW, 72,000 tons/year of industrial wastes, and 19,000 tons/year of C/D and land clearing wastes, all of which end up in landfills except for the 5,200 tons/year of yard wastes recycled to compost. As discussed above, I estimate that the C/D landfill receives about 9,000 tons/year of MSW wood and about 2,000 tons/year of $\mathrm{C} / \mathrm{D}$ and land clearing wood waste. In addition, I estimate that both the municipal and industrial waste streams going to landfills contain about 5\% wood. Thus, another 2,000 tons/year of MSW wood enter the sanitary landfill (bringing the total for MSW wood entering landfills to about 11,000 tons/year), and about 4,000 tons/year of industrial wood wastes are landfilled.

\section{MSW Wood (Primarily Tree and Yard Wastes)}

As discussed above, about 11,000 tons/year of MSW wood are included in the solid waste going to landfills in the area. The City of Florence yard and wood waste recycling program gives away an estimated 5,200 tons/year of compost. None of the waste hauling companies I talked to do any wood separation or grinding in the Florence area. Carolina Power \& Light Company uses Asplundh Tree Service Company for tree trimming; the Asplundh manager did not return my calls. Pee Dee Electric Cooperative Inc. serves some of the rural areas near Florence. The manager of the Cooperative did not return my calls. Based on information gathered from Asplundh, Bartlett, and utilities in other areas, I estimate that about 3,000 tons/year of wood are generated by utility tree trimming operations in the Florence area. About 1,000 tons/year of this wood are given away as firewood, and the remainder is given away as mulch.

The Florence Yellow Pages list eight tree service companies, each of which uses one crew, generating in all about 8,000 tons/year of wood from tree trimming and removals. Some of this wood is given away or sold as mulch and firewood; my estimate is 2,000 tons/year of firewood and 4,000 tons/year of mulch. The remainder, about 2,000 tons/year, is disposed of at the county C/D landfill for about $\$ 10 /$ ton, or at private rural disposal sites. (Note that in the summary table below I have assumed that this 2,000 tons/year is included in the 11,000 tons/year discussed above, because the Florence County $\mathrm{C} / \mathrm{D}$ manager specifically identified about 9,000 tons/year of yard and tree wastes entering his landfill.)

Table 19-2 summarizes the estimated resources of MSW wood in the Florence metropolitan area. The total estimate, 25,200 tons/year (of which about 11,000 tons/year enter landfills or are dumped or burned in rural areas), is equivalent to 0.220 tons/year/person based on the Florence metropolitan area population of 114,344. This is above the weighted average of 0.209 tons/year/person of MSW wood for the 30 metropolitan areas, which range from 0.134 to 0.538 tons/year/person. 
Table 19-2

Resource Estimate for MSW Wood in Florence, South Carolina

Tons/year

\begin{tabular}{|c|c|c|c|c|}
\hline & Mulch & $\begin{array}{l}\text { Fire- } \\
\text { wood }\end{array}$ & $\begin{array}{l}\text { Land- } \\
\text { fill * }\end{array}$ & Total \\
\hline Hauled with trash & & & 9,000 & 9,000 \\
\hline Municipal yard waste recycl. & 5,200 & & & 5,200 \\
\hline Utility tree trimming & 2,000 & 1,000 & & 3,000 \\
\hline Private tree service co's & 4,000 & 2,000 & 2,000 & 8,000 \\
\hline Total & 11,200 & 3,000 & 11,000 & 25,200 \\
\hline
\end{tabular}

\section{Industrial Wood Wastes}

The Florence Yellow Pages list one local company under Pallets and Skids; one company under Trusses-Construction; one company under Lumber-Wholesale; five companies under Lumber; and six companies under Cabinet Makers or Furniture Designers \& Custom Builders (woodworking companies). The pallet company is a small home-based business that did not return my calls. Most of the companies supplying and recycling pallets in the Florence area are located outside the Florence metropolitan area. Thus, even though there is significant industrial activity in the area, and many pallets are used, the wood wastes from the recycling of those pallets are generated outside the metropolitan area.

The wholesale lumber company in Florence owns the truss company. Wood wastes from the truss company are delivered to the lumber company, and added to the wood wastes produced at the lumber mill. All of these wood wastes are used as fuel within the mill itself. One of the retail lumber companies in the Florence area generates small quantities of waste wood. Less than 100 tons/year of sawdust go to animal bedding. The other retail lumber companies in the area do no cutting and produce essentially no wood wastes. The six woodworking companies (cabinet and custom furniture makers) in the Florence area are all very small companies that generate a total of less than 100 tons/year of wood wastes.

As discussed above, about 4,000 tons/year of industrial wood wastes are estimated to enter landfills in the Florence area. Ignoring the very small amounts of wood wastes from small woodworking shops, 4,000 tons/year is my estimate of the industrial wood waste resource in the Florence metropolitan area, and is equivalent to about 0.035 tons/year/person based on the Florence metropolitan area population of 114,344. This is below the weighted average of 0.048 tons/year/person of industrial wood waste for the 30 metropolitan areas surveyed; the range is from 0.001 to 0.488 tons/year/person.

\section{Construction/Demolition Wood Wastes}

As discussed above in the subsection on MSW Collection and Disposal, I estimate that about 2,000 tons/year of wood from C/D and land clearing operations are disposed of in the Florence County C/D landfill. The estimated total of 2,000 tons/year of C/D wood wastes is equivalent to 0.017 tons/year/person based on the Florence metropolitan area population of 114,344 . This is below the weighted average of 0.076 tons/year/person of $\mathrm{C} / \mathrm{D}$ wood for the 30 metropolitan areas surveyed; the range is from 0.015 to 0.250 tons/year/person. 


\section{Supply Curve}

Figure 19-1 shows the supply curve for urban wood wastes in the Florence area. Table 19-3 shows the data and assumptions used to produce the supply curve.

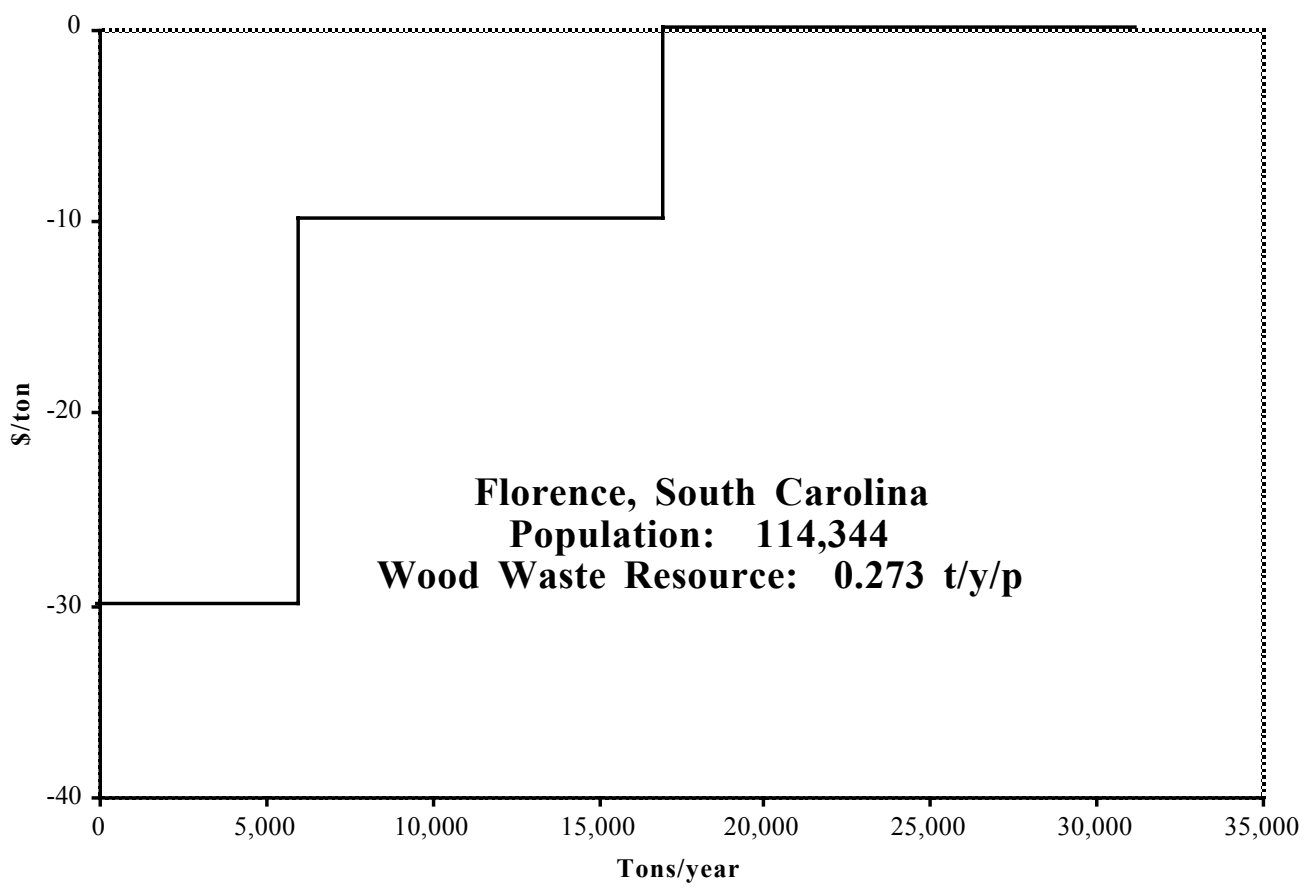

Figure 19-1. Supply Curve for Urban Wood Wastes in Florence, South Carolina

Table 19-3

Data and Assumptions Used in Supply Curve for Florence

Tons/year Cumulative \$/ton

Assumptions/Comments

6,000

$6,000 \frac{\$ 1 t 0 n}{-30}$

Landfilled with MSW and industrial waste

11,000

17,000

$-10$

Landfilled in C/D landfill (C/D and MSW wood)

14,200

31,200

0 Firewood and mulch - given away 


\section{Greenville-Spartanburg, South Carolina Population (1990): 640,861}

Known for textiles and peaches, Greenville and Spartanburg have recently attracted some major manufacturing facilities. The cities are about 25 miles apart along I-85, and their populations are only about 58,000 and 44,000, which means that some 539,000 people live in the nearby small towns and rural areas. Greenville is in Greenville County, and Spartanburg is in Spartanburg County. I assumed that data on these two counties were effectively the same as data on the Greenville-Spartanburg metropolitan area.

Table 20-1 summarizes the data collected on urban wood resources in the GreenvilleSpartanburg area. The estimated total urban wood waste resource, 0.443 tons/year/person, is above the weighted average of 0.333 tons/year/person for the 30 metropolitan areas surveyed; the range for the 30 cities is from 0.156 to 0.829 tons/year/person. The forest products industry in the area provides a market for saw logs and biomass fuel. A local biomass energy project might be able to obtain some of the 16,000 tons/year of biomass fuel now being transported up to 100 miles away, plus 100,000-200,000 tons/year of MSW and C/D wood at a relatively low cost, and produce 8-20 MW of electricity.

Table 20-1

\section{Resource Estimate for Urban Wood Waste in Greenville-Spartanburg, South Carolina}

\begin{tabular}{|c|c|c|c|c|c|}
\hline \multirow[b]{2}{*}{ Use or Disposal Method: } & \multicolumn{4}{|c|}{ Tons/Year } & \multirow[b]{2}{*}{$\begin{array}{l}\text { Price, } \\
\text { \$/ton }\end{array}$} \\
\hline & $\begin{array}{l}\text { MSW } \\
\text { Wood }\end{array}$ & $\begin{array}{c}\text { Industr. } \\
\text { Wood }\end{array}$ & $\begin{array}{c}\text { C/D } \\
\text { Wood }\end{array}$ & Total & \\
\hline Saw $\log s$ & & & 1,000 & 1,000 & 12 \\
\hline Biomass fuel & & 16,000 & & 16,000 & 0 to 9 \\
\hline Firewood & 25,000 & 2,000 & & 27,000 & 0 \\
\hline Mulch & 116,000 & & 16,000 & 132,000 & 0 \\
\hline Animal bedding & & 2,000 & & 2,000 & 0 \\
\hline Landfill or rural dumping* & 50,000 & 6,000 & 50,000 & 106,000 & 0 to -38 \\
\hline Total & 191,000 & 26,000 & 67,000 & 284,000 & \\
\hline Total, tons/year/person & 0.298 & 0.041 & 0.105 & 0.443 & \\
\hline
\end{tabular}

*Rural dumping includes private rural disposal or burning (common in this area).

\section{Municipal Solid Waste (MSW) Collection and Disposal}

The Enoree landfill, owned by Greenville County, receives about 244,000 tons/year of MSW and about 31,000 tons/year of C/D debris, all from within the county. (Not all Greenville County solid waste goes to this landfill, however.) Yard waste and other clean wood waste received at the landfill is ground to mulch, which is given away to the public. The tipping fee for C/D waste at the Enoree landfill is \$26/ton. The Palmetto landfill, a few miles southwest of Greenville, receives a lot of the privately hauled waste in the area. The City of Greenville collects about 22,000 tons/year of MSW and takes it to the Enoree landfill. The city and the county have a joint yard waste collection program. The city shreds yard wastes and hauls them to the Enoree landfill, where they are ground along with the county's yard wastes, producing a total of about 23,000 tons/year of mulch. Some of the mulch is given away, and some is used as alternate daily cover in the landfill. The City of Spartanburg hauls its MSW and yard waste to the Wellford landfill, which is owned by Spartanburg County. About 6,400 tons/year of yard waste are hauled to the landfill by the 
city. The logs and most of the small limbs are placed in separate areas of the landfill. I believe only the leaves and a small portion of the brush are composted.

The South Carolina Department of Health and Environmental Control (DHEC) report for fiscal year 1997 (July 1996 - June 1997) includes the following data for solid waste generated in Greenville and Spartanburg Counties, in tons/year:

\begin{tabular}{|c|c|c|c|}
\hline & Greenville & Spartanburg & Total \\
\hline MSW & $492,542 *$ & 303,989 & 796,531 \\
\hline Industrial solid waste & & 27,698 & 27,698 \\
\hline $\mathrm{C} / \mathrm{D}$ debris & 49,442 & 36,427 & 85,869 \\
\hline Yard trash/land & 5,720 & 8,264 & 13,984 \\
\hline Total & 547,704 & 376,378 & 924,082 \\
\hline $\begin{array}{l}\text { Yard waste/land } \\
\text { clearing debris recycled }\end{array}$ & 34,753 & 20,821 & 55,574 \\
\hline
\end{tabular}

*295,060 tons/year of the MSW in Greenville County were "exported" to disposal sites in other counties (probably Spartanburg County, which "imported" 738,803 tons/year of MSW).

Based on the information above, my estimates of the amounts of wood waste entering landfills in the Greenville-Spartanburg metropolitan area are approximately:

MSW wood: $5 \%$ of $796,531=40,000$ tons/year;

Industrial wood: $5 \%$ of $27,698=1,000$ tons/year;

C/D wood: $20 \%$ of $85,869=17,000$ tons $/$ year.

\section{MSW Wood (Primarily Tree and Yard Wastes)}

As discussed in the subsection above, an estimated 40,000 tons/year of MSW wood waste are included in the solid waste going to landfills in the area. The Greenville-Spartanburg wood waste recycling programs produce and give away an estimated 56,000 tons/year of mulch. None of the waste hauling companies I talked to in the Greenville-Spartanburg area (including Waste Management of South Carolina) do any wood separation or grinding.

Duke Power and the Blue Ridge Electric Cooperative Inc. provide electric service in the Greenville-Spartanburg area. The tree trimming supervisors for these companies did not return my calls. Based on information gathered from Asplundh, Bartlett, and utilities in other areas, I estimate that about 20,000 tons/year of wood are generated by utility tree trimming operations in the Greenville-Spartanburg area. About 5,000 tons/year are given away as firewood, and the remainder is given away as mulch.

The Greenville and Spartanburg Yellow Pages list 70 tree service companies. Based on information from the 26 tree service companies I talked to, I estimate that there are a total of about 75 crews operating in the metropolitan area, generating about 75,000 tons/year of wood from tree trimming and removals. I estimate that about 20,000 tons/year of firewood and 45,000 tons/year of mulch are given away, and that about 10,000 tons/year are disposed of at landfills for $\$ 26 /$ ton, or on rural land.

Table 20-2 summarizes the estimated resources of MSW wood in the GreenvilleSpartanburg metropolitan area. The total estimate, 191,000 tons/year (of which about 50,000 tons/year enter landfills or are dumped or burned in rural areas), is equivalent to 
0.298 tons/year/person based on the Greenville-Spartanburg metropolitan area population of 640,861. This is above the weighted average of 0.209 tons/year/person of MSW wood for the 30 metropolitan areas, which range from 0.134 to 0.538 tons/year/person.

\section{Table 20-2 \\ Resource Estimate for MSW Wood in Greenville-Spartanburg, South Carolina Tons/year}

\begin{tabular}{|c|c|c|c|c|}
\hline & Mulch & $\begin{array}{l}\text { Fire- } \\
\text { wood }\end{array}$ & $\begin{array}{l}\text { Land- } \\
\text { fill * }\end{array}$ & Total \\
\hline Hauled with trash & & & 40,000 & 40,000 \\
\hline Municipal yard waste recycl. & 56,000 & & & 56,000 \\
\hline Utility tree trimming & 15,000 & 5,000 & & 20,000 \\
\hline Private tree service co's & 45,000 & 20,000 & 10,000 & 75,000 \\
\hline Total & 116,000 & 25,000 & 50,000 & 191,000 \\
\hline
\end{tabular}

*“Landfill” includes rural dumping and burning.

\section{Industrial Wood Wastes}

The Greenville and Spartanburg Yellow Pages list 19 local companies under Pallets and Skids; six companies under Trusses-Construction; 10 companies under Lumber-Wholesale; 32 companies under Lumber; and 92 companies under Cabinet Makers, Furniture Designers \& Custom Builders, and Furniture Manufacturers (woodworking companies). The six large pallet companies grind their wood waste and sell most of it (about 12,500 tons/year) as boiler fuel to pulp and paper companies. These large pallet companies also sell or give away about 500 tons/year of firewood, 1,000 tons/year of animal bedding, and send about 1,000 tons/year to landfills. The other 13 pallet companies in the GreenvilleSpartanburg area generate very small amounts of wood wastes. I estimate that collectively they give away about 500 tons/year of firewood and send about 500 tons/year to landfills.

The truss companies in the area produce very small amounts of waste wood, and consume them onsite as fuel or have them hauled away with the trash. Collectively, I estimate that these companies send about 1,000 tons/year of wood wastes to landfills. The wholesale lumber companies in the area produce very small quantities of wood wastes. Most of them do no cutting at all. I estimate that two of the lumber companies produce a total of about 500 tons/year of sawdust, which they give away as animal bedding. The retail lumber companies in the area generate very small quantities of waste wood. About 500 tons/year of sawdust go to animal bedding, and about 500 tons/year of sawdust go to the landfill.

One furniture manufacturer in the area is a large company that generates about 3,000 tons/year of sawdust and scraps that are given away for boiler fuel. This avoids a landfill tipping fee of about $\$ 25 /$ ton. Six of the other 91 woodworking companies in the area are big enough companies to produce measurable amounts of wood wastes. Most of their wood waste (about 2,000 tons/year) goes to landfills because it is treated wood (plywood, particleboard, melamine, etc.). About 500 tons/year of these companies' wood waste is clean and goes for boiler fuel. The remaining 85 woodworking companies are all very small companies that generate a total of 1,000 tons/year or less of wood wastes. 
Table 20-3 summarizes the estimated resources of industrial wood wastes in the GreenvilleSpartanburg metropolitan area. The total estimate of 26,000 tons/year is equivalent to about 0.041 tons/year/person based on the Greenville-Spartanburg metropolitan area population of 640,861 . This is below the weighted average of 0.048 tons/year/person of industrial wood waste for the 30 metropolitan areas surveyed; the range is from 0.001 to 0.488 tons/year/person.

Table 20-3

\section{Resource Estimate for Industrial Wood Wastes in Greenville-Spartanburg, South Carolina Tons/year}

\begin{tabular}{|c|c|c|c|c|c|}
\hline & $\begin{array}{l}\text { Fire- } \\
\text { wood }\end{array}$ & $\begin{array}{c}\text { Biomass } \\
\text { Fuel }\end{array}$ & $\begin{array}{l}\text { Animal } \\
\text { Beddin }\end{array}$ & $\begin{array}{c}\text { Land- } \\
\text { fill }\end{array}$ & Total \\
\hline Pallet companies & 1,000 & 12,500 & 1,000 & 1,500 & 16,000 \\
\hline Truss companies & & & & 1,000 & 1,000 \\
\hline Whlsl lumber co's & & & 500 & & 500 \\
\hline Retail lumber co's & & & 500 & 500 & 1,000 \\
\hline Woodworking co's & 1,000 & 3,500 & & 2,000 & 6,500 \\
\hline Other* & & & & 1,000 & 1,000 \\
\hline Total & 2,000 & 16,000 & 2,000 & 6,000 & 26,000 \\
\hline
\end{tabular}

*Industrial wood wastes going to landfills from sources I did not identify.

\section{Construction/Demolition Wood Wastes}

As discussed above under MSW Collection and Disposal, an estimated 17,000 tons/year of wood waste enter landfills with $\mathrm{C} / \mathrm{D}$ and land clearing debris in the Greenville-Spartanburg area. The Greenville and Spartanburg Yellow Pages list 12 local companies under Demolition Contractors and 18 companies under Land Clearing \& Leveling. Salvageable logs are sold to sawmills, and some wood is cut up for firewood. I have assumed that about 1,000 tons/year of saw logs are produced from land clearing operations. Any wood that does not produce revenues is burned, if it is in a location where a permit can be obtained. Other options available, depending on the location of the site (e.g., rural vs. urban) and the land owner's wishes, include grinding the wood and using it on site for landscaping, or hauling it to rural locations to fill gullies. One company grinds wood (about 60\% generated from its own land clearing operations, and 40\% from others) and sells it for landscaping mulch, along with topsoil and other products. The amount of wood mulch sold by this company is about 16,000 tons/year.

Assuming that 17,000 tons/year of C/D and land clearing wood enter landfills, I estimate that at least an equal amount, and probably twice as much, is disposed of by burning and rural dumping. My estimate for the total amount of $\mathrm{C} / \mathrm{D}$ and land clearing wood disposed of by these methods is about 50,000 tons/year. Adding the 1,000 tons/year of saw $\operatorname{logs}$ recovered, and the 16,000 tons/year of mulch produced, gives a total estimate of 67,000 tons/year of C/D wood wastes. This is equivalent to 0.105 tons/year/person based on the Greenville-Spartanburg metropolitan area population of 640,861. This is above the weighted average of 0.076 tons/year/person of $\mathrm{C} / \mathrm{D}$ wood for the 30 metropolitan areas surveyed; the range is from 0.015 to 0.250 tons/year/person. 


\section{Supply Curve}

Figure 20-1 shows the supply curve for urban wood wastes in the Greenville-Spartanburg area. Table 20-4 shows the data and assumptions used to produce the supply curve.

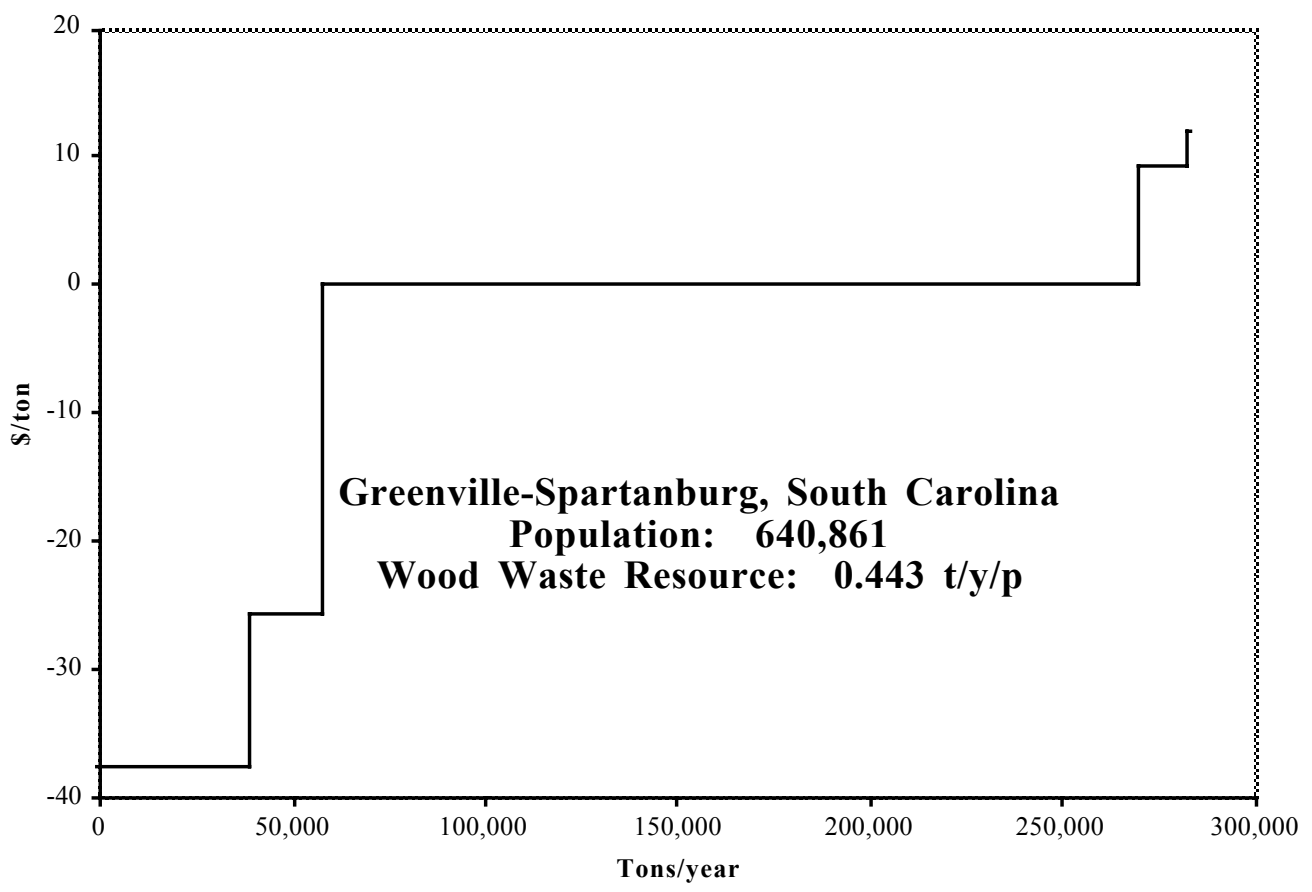

Figure 20-1. Supply Curve for Urban Wood Wastes in Greenville-Spartanburg, South Carolina

Table 20-4

Data and Assumptions Used in Supply Curve for Greenville-Spartanburg

Tons/year Cumulative $\frac{\text { \$/ton }}{39,600}$

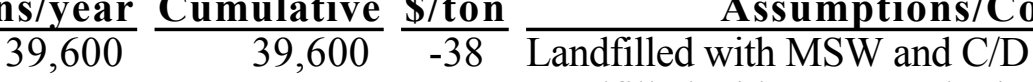

$18,400 \quad 58,000 \quad-26 \quad$ Landfilled with MSW and C/D - private landfills

$48,000 \quad 106,000 \quad 0 \quad$ Rural dumping and burning

$164,500 \quad 270,500 \quad 0 \quad$ Firewood, mulch, animal bd, biofuel - given away

12,500 283,000 9 Biofuel - sold

$1,000 \quad 284,000 \quad 12 \quad$ Saw logs - sold 
Kentucky's second largest city, Lexington is the commercial center of Bluegrass Country, a region that centers on tobacco and Thoroughbred horses. The city is the country's chief producer of bluegrass seed and white barley. More than 50 major Lexington industries manufacture everything from peanut butter to laser printers. The City of Lexington makes up nearly all of the County of Fayette. The city and county governments are merged into one entity called the Lexington-Fayette Urban County.

Table 21-1 summarizes the data collected on urban wood resources in the LexingtonFayette area. The estimated total urban wood waste resource, 0.278 tons/year/person, is below the weighted average of 0.333 tons/year/person for the 30 metropolitan areas surveyed; the range for the 30 cities is from 0.156 to 0.829 tons/year/person. The Lexington-Fayette metropolitan area does not have significant markets for waste wood, such as wood-fired boilers or wood products industries. A biomass energy project might be able to obtain about 40,000-80,000 tons/year of MSW and C/D wood at a relatively low cost, and produce 3-8 MW of electricity.

Table 21-1

Resource Estimate for Urban Wood Waste in Lexington-Fayette, Kentucky

\begin{tabular}{|c|c|c|c|c|c|}
\hline \multirow[b]{2}{*}{ Use or Disposal Method: } & \multicolumn{4}{|c|}{ Tons/Year } & \multirow[b]{2}{*}{$\begin{array}{c}\text { Price, } \\
\text { \$/ton }\end{array}$} \\
\hline & $\begin{array}{l}\text { MSW } \\
\text { Wood }\end{array}$ & $\begin{array}{c}\text { Industr. } \\
\text { Wood }\end{array}$ & $\begin{array}{c}\text { C/D } \\
\text { Wood }\end{array}$ & Total & \\
\hline Biomass fuel & & 500 & & 500 & 0 \\
\hline Firewood & 10,000 & 700 & & 10,700 & 0 \\
\hline Mulch & 49,000 & & & 49,000 & 0 \\
\hline Animal bedding & & 500 & & 500 & 0 \\
\hline Landfill or rural dumping* & 20,000 & 3,300 & 13,000 & 36,300 & 0 to -25 \\
\hline Total & 79,000 & 5,000 & 13,000 & 97,000 & \\
\hline Total, tons/year/person & 0.227 & 0.014 & 0.037 & 0.278 & \\
\hline
\end{tabular}

*Rural dumping includes private rural disposal or burning (common in this area).

\section{Municipal Solid Waste (MSW) Collection and Disposal}

The Lexington-Fayette Urban County "Area Solid Waste Management Plan Annual Report" for 1996, plus interviews with a number of waste management officials, indicated that total MSW disposal is 342,000 tons/year and total C/D debris disposal is 66,000 tons/year. About 240,000 tons/year (70\%) of the MSW is city trash that goes through the Lexington Transfer Station, which is owned by the city/county and operated by Bluegrass Waste Alliance. Five other facilities receive MSW from the Lexington-Fayette area. Tipping fees are $\$ 20-24.50 /$ ton. The C/D debris generated in the Lexington-Fayette area goes to two C/D landfills, where tipping fees are \$20-24/ton.

In 1996 Lexington started a pilot program on yard waste collection and grinding. About 3,700 households participated in the first year, and about 3,300 tons of yard waste were diverted from landfills. In 1997 the pilot program expanded to about 8,000 households, and my assumption is that this diverted about 7,000 tons (data were not in yet). Approximately 14,000 additional tons/year of yard wastes were delivered to drop-off sites. Thus, the current estimate of yard waste diverted from landfills is about 21,000 tons/year. 
A contractor grinds the yard waste and produces compost. Participants in the program are eligible to receive compost for free; the rest of the compost is sold by the contractor. Based on the information above, my estimates of the amounts of wood waste entering landfills in the Lexington-Fayette metropolitan area are approximately:

MSW wood: $5 \%$ of $342,000=17,000$ tons/year;

C/D wood: $20 \%$ of $66,000=13,000$ tons $/$ year.

\section{MSW Wood (Primarily Tree and Yard Wastes)}

As discussed above, an estimated 17,000 tons/year of MSW wood waste are included in the solid waste going to landfills in the area. The Lexington-Fayette yard waste recycling program produces an estimated 21,000 tons/year of compost. None of the waste hauling companies I talked to in the Lexington-Fayette area (including BFI and Waste Management of Kentucky) do any wood separation or grinding.

Kentucky Utilities provides electric service in the Lexington-Fayette area. The tree trimming supervisor said that about 14 tree service crews (Asplundh and other contractors) are keeping the utility lines and rights of way clear in the area, generating about 14,000 tons/year of wood. About 4,000 tons/year of this wood are given away as firewood, and the remainder is given away as mulch.

The Lexington-Fayette Yellow Pages list 17 tree service companies that I found to be actively doing tree service work. Based on the information these companies provided, I estimate that there are a total of about 27 crews operating in the metropolitan area, generating about 27,000 tons/year of wood from tree trimming and removals. Most of this wood is given away or sold as mulch and firewood; my estimate is 6,000 tons/year of firewood and 18,000 tons/year of mulch. The remainder, about 3,000 tons/year of pine that is not wanted for firewood, is burned on private rural land.

Table 21-2 summarizes the estimated resources of MSW wood in the Lexington-Fayette metropolitan area. The total estimate, 79,000 tons/year (of which about 20,000 tons/year enter landfills), is equivalent to 0.227 tons/year/person based on the Lexington-Fayette population of 348,428. This is above the weighted average of 0.209 tons/year/person of MSW wood for the 30 urban areas, which range from 0.134 to 0.538 tons/year/person.

Table 21-2

Resource Estimate for MSW Wood in Lexington-Fayette, Kentucky Tons/year

\begin{tabular}{|c|c|c|c|c|}
\hline & Mulch & $\begin{array}{l}\text { Fire- } \\
\text { wood }\end{array}$ & $\begin{array}{l}\text { Land- } \\
\text { fill* }\end{array}$ & Total \\
\hline Hauled with trash & & & 17,000 & 17,000 \\
\hline Municipal yard waste recycl. & 21,000 & & & 21,000 \\
\hline Utility tree trimming & 10,000 & 4,000 & & 14,000 \\
\hline Private tree service co's & 18,000 & 6,000 & 3,000 & 27,000 \\
\hline Total & 49,000 & 10,000 & 20,000 & 79,000 \\
\hline
\end{tabular}

*“Landfill” includes rural dumping and burning. 


\section{Industrial Wood Wastes}

The Lexington-Fayette Yellow Pages list six local companies under Pallets and Skids; two local companies under Trusses-Construction; two local companies under LumberWholesale; 19 companies under Lumber-Retail; and 38 companies under Cabinet Makers, Furniture Designers \& Custom Builders, and Furniture Manufacturers (woodworking companies). None of the pallet companies in the Lexington-Fayette area produce large amounts of wood wastes. One pallet company sends about 900 tons/year to the landfill, and one of the truss companies also sends about 2,000 tons/year of wood wastes to the landfill. Another pallet company gives about 500 tons/year to a company in southern Kentucky, and is not sure how they use the wood (my guess is fuel). The pallet and truss companies in the Lexington-Fayette area give away about 1,000 tons/year of firewood or biomass fuel, and send about 3,000 tons/year of wood wastes to landfills.

The wholesale lumber companies in the Lexington-Fayette area produce very small quantities of wood wastes. Most of them do no cutting at all. I estimate that one of the lumber companies produces a total of about 200 tons/year of sawdust, which they give away as animal bedding. The retail lumber companies in the area generate very small quantities of waste wood. About 200 tons/year of sawdust go to animal bedding, and about 200 tons/year of sawdust go to the landfill. The woodworking companies in the area produce 400 tons/year or less of wood scraps that are hauled to the landfill, used by family and friends, and/or given away as firewood.

Table 21-3 summarizes the estimated resources of industrial wood wastes in the LexingtonFayette metropolitan area. The total estimate of 5,000 tons/year is equivalent to about 0.014 tons/year/person based on the metropolitan area population of 348,428. This is below the weighted average of 0.048 tons/year/person of industrial wood waste for the 30 metropolitan areas surveyed; the range is from 0.001 to 0.488 tons/year/person.

\section{Table 21-3 \\ Resource Estimate for Industrial Wood Wastes in Lexington-Fayette, Kentucky Tons/year}

\begin{tabular}{|c|c|c|c|c|c|}
\hline & $\begin{array}{l}\text { Fire- } \\
\text { wood }\end{array}$ & $\begin{array}{c}\text { Biomass } \\
\text { Fuel }\end{array}$ & $\begin{array}{l}\text { Animal } \\
\text { Beddin }\end{array}$ & $\begin{array}{c}\text { Land- } \\
\text { fill }\end{array}$ & Total \\
\hline Pallet \& truss co's & 500 & 500 & & 3,000 & 4,000 \\
\hline Whlsl lumber co's & & & 200 & & 200 \\
\hline Retail lumber co's & & & 200 & 200 & 400 \\
\hline Woodworking co's & 200 & & 100 & 100 & 400 \\
\hline Total & 700 & 500 & 500 & 3,300 & 5,000 \\
\hline
\end{tabular}

\section{Construction/Demolition Wood Wastes}

The Lexington-Fayette Yellow Pages list seven companies under Demolition Contractors and one company under Land Clearing \& Leveling. All of these companies said they dispose of their debris at landfills. As discussed above under MSW Collection and Disposal, an estimated 13,000 tons/year of wood waste enter landfills with $\mathrm{C} / \mathrm{D}$ and land clearing debris in the Lexington-Fayette area, which is equivalent to 0.037 tons/year/person based on the Lexington-Fayette metropolitan area population of 348,428. This is below the 
weighted average of 0.076 tons/year/person of $\mathrm{C} / \mathrm{D}$ wood for the 30 metropolitan areas surveyed; the range is from 0.015 to 0.250 tons/year/person.

\section{Supply Curve}

Figure 21-1 shows the supply curve for urban wood wastes in the Lexington-Fayette area. Table 21-4 shows the data and assumptions used to produce the supply curve.

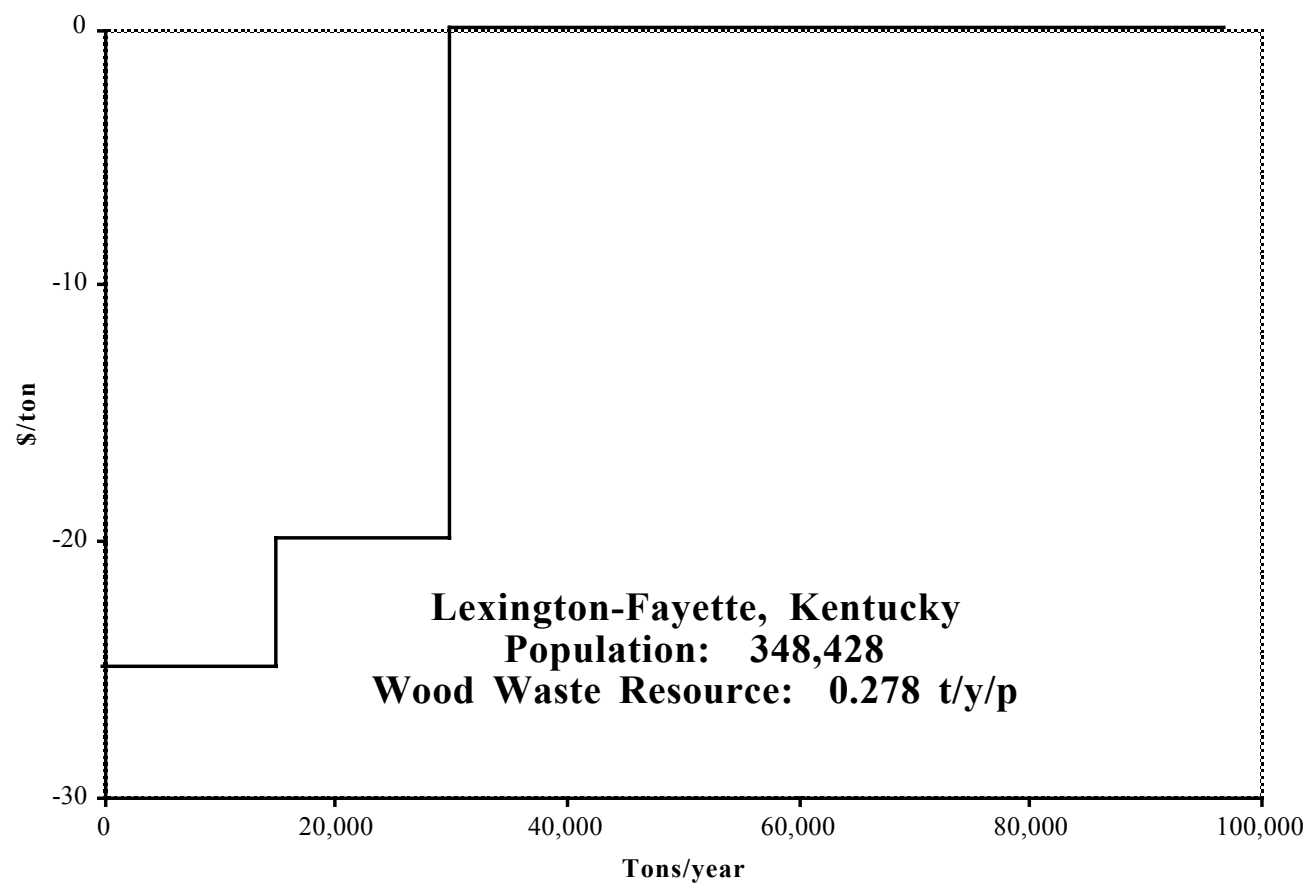

Figure 21-1. Supply Curve for Urban Wood Wastes in Lexington-Fayette, Kentucky

Table 21-4

Data and Assumptions Used in Supply Curve for Lexington-Fayette

Tons/year Cumulative \$/ton

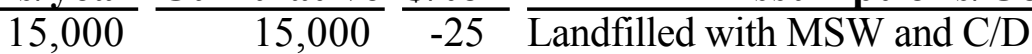

$15,000 \quad 30,000 \quad-20 \quad$ Landfilled with MSW and C/D

$6,300 \quad 36,300 \quad 0 \quad$ Rural dumping and burning

$60,700 \quad 97,000 \quad 0 \quad$ Firewood, mulch, animal bd, biofuel - given away 


\section{Memphis, Tennessee Population (1990): 981,747}

As a metropolis for Tennessee, Mississippi, and Arkansas, Memphis has been called the capital of the Mississippi Delta. Federal Express and several large trucking firms are based in Memphis; this creates a large market for pallets. Memphis has a major convention center, modern skyscrapers, expressways, large suburban areas, and a major international airport. Although the metropolitan area spills across the Tennessee state border into rural areas of both Arkansas and Mississippi, the vast majority of the Memphis metropolitan area's population and industry are within Shelby County, Tennessee.

Table 22-1 summarizes the data collected on urban wood resources in the Memphis area. The estimated total urban wood waste resource, 0.378 tons/year/person, is above the weighted average of $0.333 \mathrm{tons} / \mathrm{year} / \mathrm{person}$ for the 30 cities surveyed; the range is from 0.156 to 0.829 tons/year/person. There are not many local biomass fuel users or other wood waste users, although TVA's Allen Fossil Plant has been testing cofiring of wood wastes with coal. A biomass energy project might be able to obtain about 200,000300,000 tons/year of wood at a relatively low cost, and produce 15-30 MW of electricity.

Table 22-1

Resource Estimate for Urban Wood Waste in Memphis, Tennessee

\begin{tabular}{|c|c|c|c|c|c|}
\hline \multirow[b]{2}{*}{ Use or Disposal Method: } & \multicolumn{4}{|c|}{ Tons/Year } & \multirow[b]{2}{*}{$\begin{array}{l}\text { Price, } \\
\text { \$/ton }\end{array}$} \\
\hline & $\begin{array}{l}\text { MSW } \\
\text { Wood }\end{array}$ & $\begin{array}{c}\text { Industr. } \\
\text { Wood }\end{array}$ & $\underset{\text { Wood }}{\text { C/D }}$ & Total & \\
\hline Furnish for particleboard & & 3,000 & & 3,000 & 3 \\
\hline Firewood & 6,000 & 6,000 & & 12,000 & 0 \\
\hline Mulch (ground cover) & 90,000 & 3,000 & 40,000 & 133,000 & 0 \\
\hline Animal bedding & & 3,500 & & 3,500 & 0 \\
\hline Incineration & & 50,000 & 50,000 & 100,000 & 0 to -2 \\
\hline Landfill & 55,000 & 4,500 & 60,000 & 119,500 & -17 to -28 \\
\hline Total & 151,000 & 70,000 & 150,000 & 371,000 & \\
\hline Total, tons/year/person & 0.154 & 0.071 & 0.153 & 0.378 & \\
\hline
\end{tabular}

\section{Municipal Solid Waste (MSW) Collection and Disposal}

The Memphis metropolitan area generates about 1,100,000 tons/year of MSW and about 300,000 tons/year of $\mathrm{C} / \mathrm{D}$ debris. The city collects about 370,000 tons/year of MSW; private haulers collect the rest. Most of the MSW goes through four transfer stations in the Memphis area, and from there to two BFI landfills in Shelby county. The city negotiated a low tipping fee (about \$16.75/ton) with BFI in return for agreeing not to open its own landfill. USA Waste will open a large landfill in Mississippi soon, and several other large private landfills in the region keep tipping fees low. The general public pays about $\$ 28 /$ ton at the BFI landfills in Shelby County. C/D landfills in the area charge \$5-6 per cubic yard, which is equivalent to about $\$ 16-20$ per ton of wood.

The City of Memphis "Earth Complex" is a yard waste grinding and composting operation that currently receives about 25,000 tons/year of woody material. The mulch is used in city parks and other city projects, given away to the public, or sold. About 90,000 tons/year of mulch are produced in Shelby County through the combined efforts of the City and County programs, private companies, and the Memphis Light Gas \& Water Division, which generates about 18,000 tons/year of mulch from its utility tree trimming operations. Based 
on the information above, my estimates of the amounts of wood waste entering landfills in the Memphis metropolitan area are approximately:

MSW wood: $5 \%$ of $1,100,000=55,000$ tons/year;

C/D wood: $20 \%$ of $300,000=60,000$ tons $/$ year.

\section{MSW Wood (Primarily Tree and Yard Wastes)}

As discussed above, an estimated 55,000 tons/year of MSW wood waste are included in the solid waste going to landfills in the area. The Memphis yard waste recycling program produces an estimated 25,000 tons/year of mulch. None of the waste hauling companies I talked to in the Memphis area (including BFI and Waste Management of Tennessee) do any wood separation or grinding. As discussed above, the Memphis Light Gas \& Water Division generates about 18,000 tons/year of mulch through its tree trimming operations. I estimate that the tree service contractors (Asplundh and others) working for the utility also generate about 3,000 tons/year of firewood, most of which is given to property owners.

The Memphis Yellow Pages list 45 tree service companies that I found to be actively doing tree service work. About 50 crews operate in the area, generating about 50,000 tons/year of wood from tree trimming and removals. About 3,000 tons/year are cut into firewood, and about 47,000 tons/year are hauled to J\&B Company to be ground to mulch.

Table 22-2 summarizes the estimated resources of MSW wood in the Memphis area. The total estimate, 151,000 tons/year (of which about 55,000 tons/year enter landfills), is equivalent to 0.154 tons/year/person based on the Memphis metropolitan area population of 981,747. This is below the weighted average of 0.209 tons/year/person of MSW wood for the 30 metropolitan areas, which range from 0.134 to 0.538 tons/year/person.

\section{Table 22-2 \\ Resource Estimate for MSW Wood in Memphis, Tennessee Tons/year}

\begin{tabular}{|c|c|c|c|c|}
\hline & Mulch & $\begin{array}{l}\text { Fire- } \\
\text { wood }\end{array}$ & $\begin{array}{c}\text { Land- } \\
\text { fill }\end{array}$ & Total \\
\hline Hauled with trash & & & 55,000 & 55,000 \\
\hline Municipal yard waste recycl. & 25,000 & & & 25,000 \\
\hline Utility tree trimming & 18,000 & 3,000 & & 21,000 \\
\hline Private tree service co's & 47,000 & 3,000 & & 50,000 \\
\hline Total & 90,000 & 6,000 & 55,000 & 151,000 \\
\hline
\end{tabular}

\section{Industrial Wood Wastes}

The Memphis Yellow Pages list 25 local companies under Pallets and Skids; one local company under Trusses-Construction; 20 local companies under Lumber-Wholesale; 21 companies under Lumber; and 56 companies under Cabinet Makers, Furniture Designers \& Custom Builders, and Furniture Manufacturers (woodworking companies). Incineration is the favored disposal method for pallet wood waste. Wood Processing Inc. incinerates about 40,000 tons/year of wood waste for at least 10 pallet companies. At least four pallet companies have their own incinerators, which consume a total of about 10,000 tons/year of wood waste. If the energy in these combustors were converted to electricity at $30 \%$ efficiency, it would generate about 9-10 MW. Other uses or disposal methods for pallet wood waste in the Memphis area include furnish for particleboard (about 3,000 tons/year); 
firewood (about 3,000 tons/year); mulch (about 3,000 tons/year); animal bedding (about 1,500 tons/year); and landfill (about 1,500 tons/year).

The wholesale lumber companies in the Memphis area produce about 1,000 tons/year of sawdust that go to animal bedding, 1,000 tons/year of scraps that go to firewood, and about 1,000 tons/year of wood wastes that are hauled to the landfill. The retail lumber companies in the Memphis area generate about the same amounts in the same three categories. The woodworking companies in the area generate 2,000 tons/year or less of wood scraps that are hauled to the landfill or given away as firewood.

Table 22-3 summarizes the estimated resources of industrial wood wastes in the Memphis metropolitan area. The total estimate of 70,000 tons/year is equivalent to about 0.071 tons/year/person based on the Memphis metropolitan area population of 981,747. This is above the weighted average of 0.048 tons/year/person of industrial wood waste for the 30 metropolitan areas surveyed; the range is from 0.001 to 0.488 tons/year/person.

Table 22-3

\section{Resource Estimate for Industrial Wood Wastes in Memphis, Tennessee Tons/year}

\begin{tabular}{|c|c|c|c|c|c|c|}
\hline & $\begin{array}{l}\text { Incinera- } \\
\text { tion }\end{array}$ & $\begin{array}{l}\text { Fire- } \\
\text { wood }\end{array}$ & $\begin{array}{l}\text { Pbd or } \\
\text { Mulch }\end{array}$ & $\begin{array}{l}\text { Animal } \\
\text { Beddin }\end{array}$ & $\begin{array}{c}\text { Land- } \\
\text { fill }\end{array}$ & Total \\
\hline Pallet companies & 50,000 & 3,000 & 6,000 & 1,500 & 1,500 & 62,000 \\
\hline Whlsl lumber co's & & 1,000 & & 1,000 & 1,000 & 3,000 \\
\hline Retail lumber co's & & 1,000 & & 1,000 & 1,000 & 3,000 \\
\hline Woodworking co's & & 1,000 & & & 1,000 & 2,000 \\
\hline Total & 50,000 & 6,000 & 6,000 & 3,500 & 4,500 & 70,000 \\
\hline
\end{tabular}

\section{Construction/Demolition Wood Wastes}

As discussed above under MSW Collection and Disposal, an estimated 60,000 tons/year of wood waste enter landfills with $\mathrm{C} / \mathrm{D}$ and land clearing debris in the Memphis area. The Memphis Yellow Pages list 16 local companies under Demolition Contractors and two companies under Land Clearing \& Leveling. Most of their debris goes to landfills. However, one private company, Brown's ET Landscape Co., grinds about 40,000 tons/year of land clearing wood debris to mulch. Also, one C/D landfill operator, at the Frank Road landfill, incinerates land clearing and C/D wood debris. He did not disclose the amount, but information from others indicated that it is at least 50,000 tons/year. Thus, my estimate for C/D and land clearing wood in the Memphis area is 150,000 tons/year. This is equivalent to 0.153 tons/year/person based on the Memphis metropolitan area population of 981,747 . This is above the weighted average of 0.076 tons/year/person of $\mathrm{C} / \mathrm{D}$ wood for the 30 metropolitan areas surveyed; the range is from 0.015 to 0.250 tons/year/person. 


\section{Supply Curve}

Figure 22-1 shows the supply curve for urban wood wastes in the Memphis area. Table 22-4 shows the data and assumptions used to produce the supply curve.

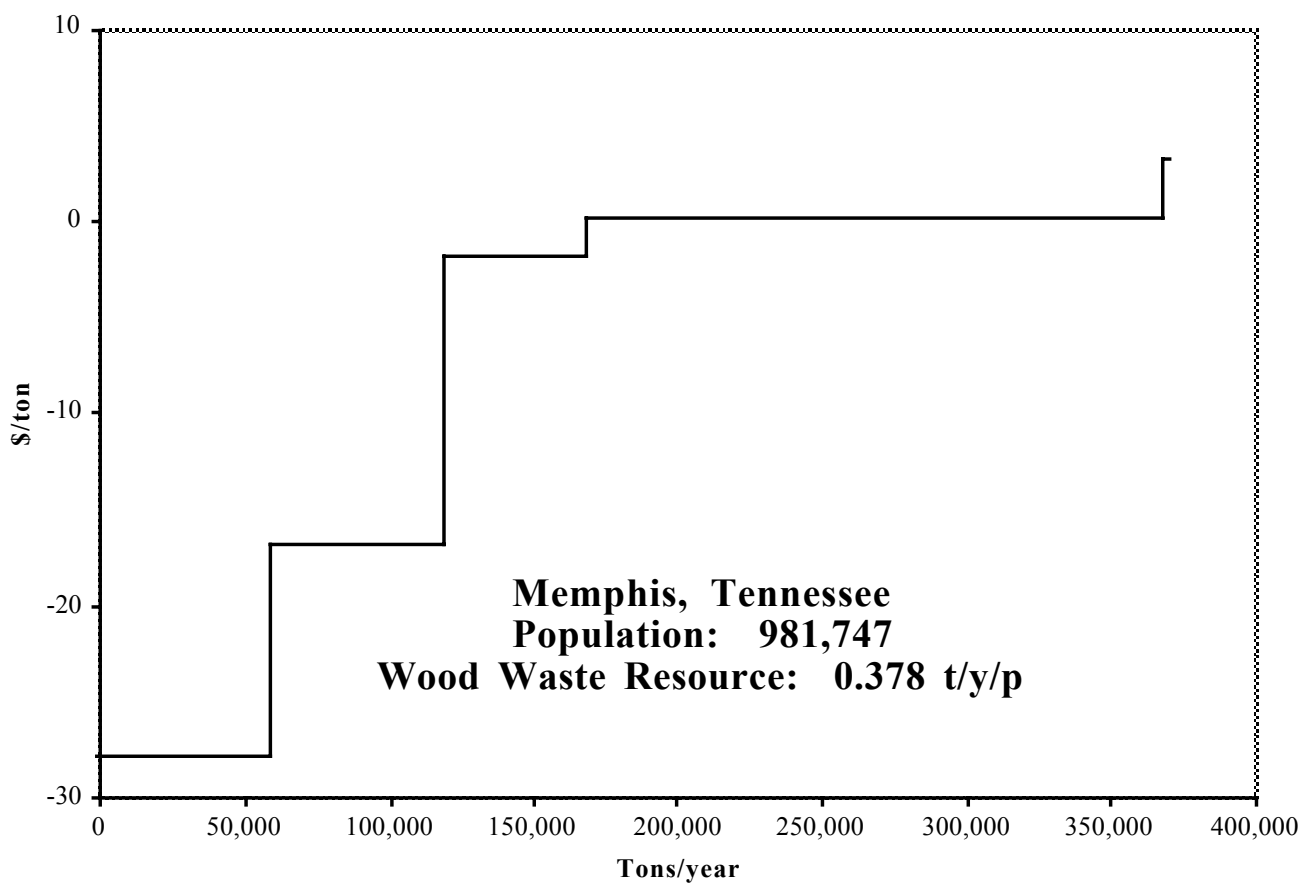

Figure 22-1. Supply Curve for Urban Wood Wastes in Memphis, Tennessee

Table 22-4

Data and Assumptions Used in Supply Curve for Memphis

Tons/year Cumulative $\frac{\text { \$ton }}{59,500}$

59,500

60,000

50,000

50,000

148,500

3,000

$59,500 \frac{\$}{-28}$

119,500

169,500

219,500

368,000

371,000
Assumptions/Comments

Landfilled with MSW and C/D

-17 Landfilled with MSW and C/D

-2 Incineration

Incineration

Firewood, mulch, animal bedding - given away

Furnish for particleboard - sold 
Decatur is in northern Alabama, on the south side of the Tennessee River. Huntsville is across the river and about 20 miles east of Decatur. Reduced to four buildings by the end of the Civil War and blighted by a yellow fever epidemic in 1888, Decatur survived and then prospered when chemical companies were established in the 1950s. Decatur is in Morgan County. My data collection effort covered both the city and the county. I did not collect data from Limestone County, across the Tennessee River.

Table 23-1 summarizes the data collected on urban wood resources in the Decatur area. The estimated total urban wood waste resource, 0.426 tons/year/person, is above the weighted average of 0.333 tons/year/person for the 30 metropolitan areas surveyed; the range for the 30 cities is from 0.156 to 0.829 tons/year/person. Decatur has markets available for biofuel that have not been fully developed. Monsanto, American Fruit, and TVA have discussed the possibility of cofiring wood wastes in their coal-fired boilers. If a biomass energy project were developed in the Decatur area, it might be able to obtain about 20,00030,000 tons/year of wood at a relatively low cost, and produce 1-3 MW of electricity.

Table 23-1

Resource Estimate for Urban Wood Waste in Decatur, Alabama

\begin{tabular}{|c|c|c|c|c|c|}
\hline \multirow[b]{2}{*}{ Use or Disposal Method: } & \multicolumn{4}{|c|}{ Tons/Year } & \multirow[b]{2}{*}{$\begin{array}{c}\text { Price } \\
\text { \$/ton }\end{array}$} \\
\hline & $\begin{array}{l}\text { MSW } \\
\text { Wood }\end{array}$ & $\begin{array}{l}\text { Industr. } \\
\text { Wood }\end{array}$ & $\begin{array}{c}\text { C/D } \\
\text { Wood }\end{array}$ & Total & \\
\hline Biomass fuel & & 7,000 & & 7,000 & 0 to 3 \\
\hline Animal bedding & & 8,200 & & 8,200 & 0 to 3 \\
\hline Firewood & 4,000 & 1,000 & & 5,000 & 0 \\
\hline Mulch (ground cover) & 22,000 & & & 22,000 & 0 \\
\hline Landfill or rural dumping* & 4,000 & 1,800 & 8,000 & 13,800 & 0 to -25 \\
\hline Total & 30,000 & 18,000 & 8,000 & 56,000 & \\
\hline Total, tons/year/person & 0.228 & 0.137 & 0.061 & 0.426 & \\
\hline
\end{tabular}

*Rural dumping includes private rural disposal or burning (common in this area).

\section{Municipal Solid Waste (MSW) Collection and Disposal}

Decatur picks up residential garbage and yard waste. The city/county landfill receives about 67,000 tons/year of MSW and 40,000 tons/year of C/D debris, and the compost site at the landfill produces about 13,000 tons/year of compost and mulch from the city's yard waste. In addition, BFI hauls about 20,000 tons/year of MSW to their own landfill. Tipping fees are $\$ 25 /$ ton at the city/county landfill and $\$ 20 /$ ton at the BFI landfill. The mulch and compost produced at the city/county landfill are sold and given away.

Monsanto, 3M, and some lumber companies discard their broken pallets at the landfill. They are kept in a separate pile on the 200-by-300 foot concrete pad at the landfill compost site. The ground pallet wood has been sold to Champion Paper as boiler fuel in the past, but currently is used on the landfill site as road cover material and alternate daily cover. The amount is about 1,200 tons/year.

Based on the information above, my estimates of the amounts of wood waste entering landfills in the Decatur metropolitan area are approximately: 
MSW wood: $5 \%$ of $87,000=4,000$ tons/year;

Industrial wood: 1,200 tons/year;

C/D wood: $20 \%$ of $40,000=8,000$ tons/year.

\section{MSW Wood (Primarily Tree and Yard Wastes)}

As discussed in the subsection above, an estimated 4,000 tons/year of MSW wood waste are included in the solid waste going to landfills in the area. The Decatur yard waste recycling program produces an estimated 13,000 tons/year of mulch and compost. The only major waste hauling company in the Decatur area, BFI, hauls waste to its own landfill. It does no wood separation or grinding.

The Decatur Utilities electric department has three contract tree service crews (two from Asplundh and one from Decatur Utilities) trimming trees along its rights of way. These operations generate about 3,000 tons/year of mulch and firewood, mostly given away.

The Decatur Yellow Pages list eight tree service companies that I found to be actively doing tree service work. About ten crews operate in the metropolitan area, generating about 10,000 tons/year of wood from tree trimming and removals $(3,000$ tons/year of firewood and 7,000 tons/year of mulch).

Table 23-2 summarizes the estimated resources of MSW wood in the Decatur area. The total estimate, 30,000 tons/year (of which about 4,000 tons/year enter landfills), is equivalent to 0.228 tons/year/person based on the Decatur metropolitan area population of 131,556. This is above the weighted average of 0.209 tons/year/person of MSW wood for the 30 metropolitan areas, which range from 0.134 to 0.538 tons/year/person.

\section{Table 23-2 \\ Resource Estimate for MSW Wood in Decatur, Alabama Tons/year}

\begin{tabular}{|c|c|c|c|c|}
\hline & Mulch & $\begin{array}{l}\text { Fire- } \\
\text { wood }\end{array}$ & $\begin{array}{l}\text { Land- } \\
\text { fill * }\end{array}$ & Total \\
\hline Hauled with trash & & & 4,000 & 4,000 \\
\hline Municipal yard waste recycl. & 13,000 & & & 13,000 \\
\hline Utility tree trimming & 2,000 & 1,000 & & 3,000 \\
\hline Private tree service co's & 7,000 & 3,000 & & 10,000 \\
\hline Total & 22,000 & 4,000 & 4,000 & 30,000 \\
\hline
\end{tabular}

\section{Industrial Wood Wastes}

The Decatur Yellow Pages list six local companies under Pallets and Skids; one local company under Trusses-Construction; three local companies under Lumber-Wholesale; nine companies under Lumber-Retail; and 39 companies under Cabinet Makers, Furniture Designers \& Custom Builders, and Furniture Manufacturers (woodworking companies). As discussed above in the subsection on MSW Collection and Disposal, an estimated 1,200 tons/year of pallet wood waste are used at the city/county landfill site for road cover and alternate daily cover. The pallet companies in the Decatur area sell most of their sawdust and ground-up wood scraps (about 5,000 tons/year) as boiler fuel to Champion 
International, Mead Container Corp., and Jack Daniels Company. In addition, some pallet wood scraps are given away as firewood (about 500 tons/year), and some pallet waste wood is burned in rural areas (300 tons/year).

One of the three wholesale lumber companies in the Decatur area uses its wood scraps and sawdust (about 2,000 tons/year) as fuel in its own boiler, producing steam for drying kilns. This company actually buys waste wood from others in order to generate the required steam. Another wholesale lumber company sells its sawdust and ground-up wood scraps (about 8,000 tons/year) to a major poultry farm. This poultry farm also obtains sawdust from several other sources outside the Decatur metropolitan area. The third wholesale lumber company in the Decatur area does no wood cutting onsite.

The retail lumber companies in the area generate about 200 tons/year of sawdust that go to animal bedding, and about 200 tons/year of small wood scraps that go to firewood. The woodworking companies in the Decatur area generate 600 tons/year or less of wood scraps that are hauled to the landfill, used by family and friends, and/or given away as firewood.

Table 23-3 summarizes the estimated resources of industrial wood wastes in the Decatur metropolitan area. The total estimate of 18,000 tons/year is equivalent to about 0.137 tons/year/person based on the Decatur metropolitan area population of 131,556. This is above the weighted average of 0.048 tons/year/person of industrial wood waste for the 30 metropolitan areas surveyed; the range is from 0.001 to 0.488 tons/year/person.

Table 23-3

\section{Resource Estimate for Industrial Wood Wastes in Decatur, Alabama} Tons/year

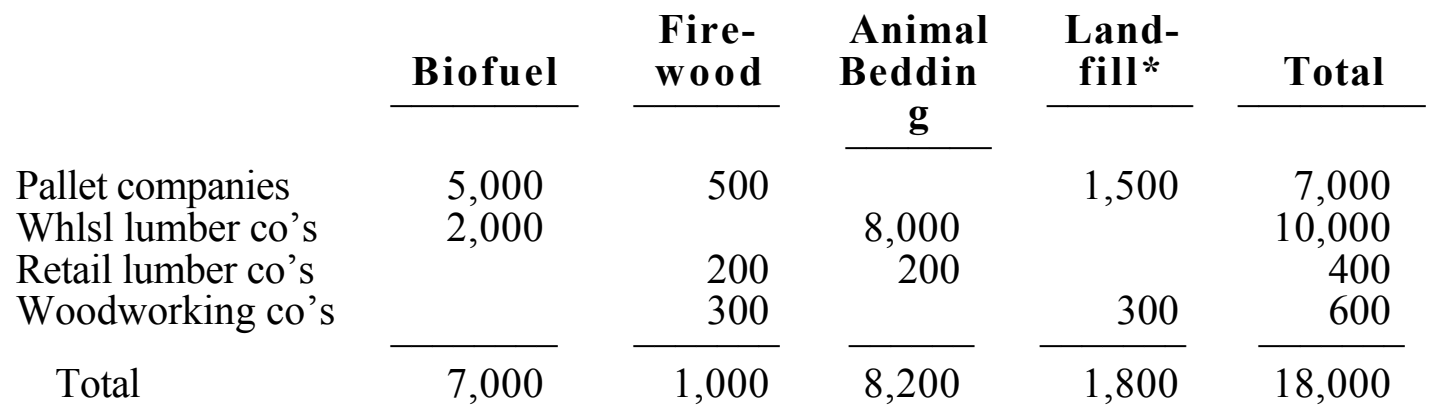

*Landfill includes burning in rural areas (about 300 tons/year in this case).

\section{Construction/Demolition Wood Wastes}

The Decatur Yellow Pages list three local companies under Demolition Contractors and four companies under Land Clearing \& Leveling. Most of their debris goes to landfills. As discussed above under MSW Collection and Disposal, an estimated 8,000 tons/year of wood waste enter landfills with $\mathrm{C} / \mathrm{D}$ and land clearing debris in the Decatur area. This is equivalent to 0.061 tons/year/person based on the Decatur metropolitan area population of 131,556. This is below the weighted average of 0.076 tons/year/person of $C / D$ wood for the 30 metropolitan areas surveyed; the range is from 0.015 to 0.250 tons/year/person. 


\section{Supply Curve}

Figure 23-1 shows the supply curve for urban wood wastes in the Decatur area. Table 234 shows the data and assumptions used to produce the supply curve.

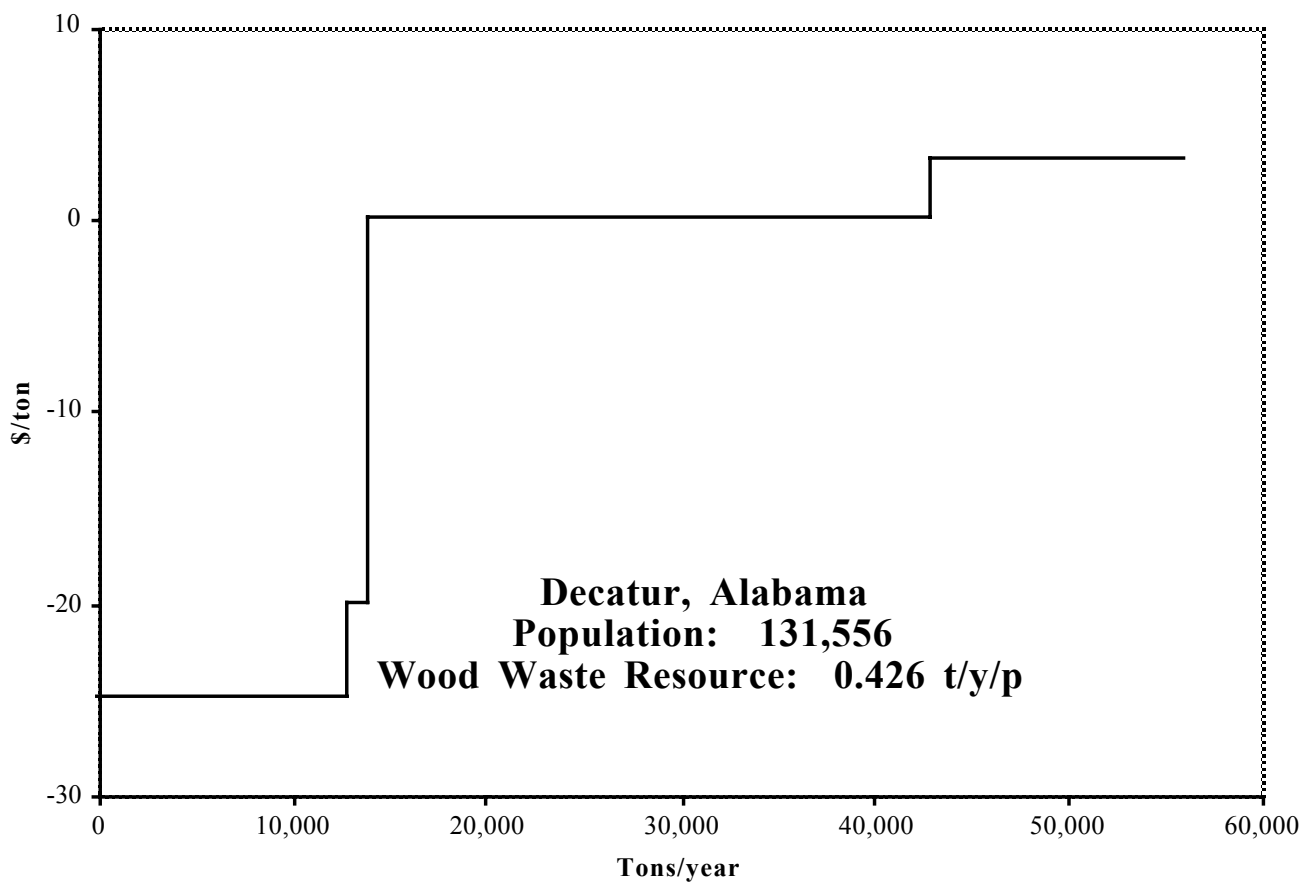

Figure 23-1. Supply Curve for Urban Wood Wastes in Decatur, Alabama

Table 23-4

Data and Assumptions Used in Supply Curve for Decatur

Tons/year Cumulative $\underline{\text { \$ton }}$

12,800

$12,800 \frac{\$ / t}{-25}$

Assumptions/Comments

1,000

13,800

$-20$

Landfilled with MSW and C/D - public landfill

28,200

42,000

1,000

43,000

0

Landfilled with MSW - private landfill

13,000

56,000

Firewood, mulch, animal bedding - given away

Rural dumping or burning

Biofuel and animal bedding - sold 
Macon and Warner Robins are in central Georgia, in Bibb County and Houston County, respectively. Macon is about 20 miles north of Warner Robins; both cities are on the Ocmulgee River. Although the Census Bureau considers Macon-Warner Robins to be a single metropolitan area, functionally they are separate. It was necessary to use both cities' phone books in order to locate all of the relevant companies and agencies. There are relatively few industrial plants in the area. One of the most important features of the local economy is Robins Air Force Base.

Table 24-1 summarizes the data collected on urban wood resources in the Macon-Warner Robins area. The estimated total urban wood waste resource, 0.347 tons/year/person, is above the weighted average of 0.333 tons/year/person for the 30 metropolitan areas surveyed; the range for the 30 cities is from 0.156 to 0.829 tons/year/person. Most of the pallet wood waste in the Macon-Warner Robins area is used for biomass fuel by regional paper mills. Most of the other wood wastes are landfilled or used as mulch or firewood. A biomass energy project could probably obtain about 40,000-70,000 tons/year of wood at a relatively low cost, and produce 3-7 MW of electricity.

Table 24-1

\section{Resource Estimate for Urban Wood Waste in Macon-Warner Robins, Georgia}

\begin{tabular}{|c|c|c|c|c|c|}
\hline \multirow[b]{2}{*}{ Use or Disposal Method: } & \multicolumn{4}{|c|}{ Tons/Year } & \multirow[b]{2}{*}{$\begin{array}{c}\text { Price } \\
\text { \$/ton }\end{array}$} \\
\hline & $\begin{array}{l}\text { MSW } \\
\text { Wood }\end{array}$ & $\begin{array}{c}\text { Industr. } \\
\text { Wood }\end{array}$ & $\begin{array}{c}\text { C/D } \\
\text { Wood }\end{array}$ & Total & \\
\hline Saw logs & & & 2,000 & 2,000 & $>10$ \\
\hline Biomass fuel & & 5,000 & & 5,000 & 0 to 3 \\
\hline Firewood & 10,000 & 1,300 & 1,000 & 12,300 & 0 \\
\hline Mulch (ground cover) & 36,000 & & 2,000 & 38,000 & 0 \\
\hline Animal bedding & & 400 & & 400 & 0 \\
\hline Landfill or rural dumping* & 29,000 & 800 & 10,000 & 39,800 & 0 to -28 \\
\hline Total & 75,000 & 7,500 & 15,000 & 97,500 & \\
\hline Total, tons/year/person & 0.267 & 0.027 & 0.053 & 0.347 & \\
\hline
\end{tabular}

*Rural dumping includes private rural disposal or burning (common in this area).

\section{Municipal Solid Waste (MSW) Collection and Disposal}

Bibb County (including Macon) generated about 276,000 tons/year of solid waste, and Houston County (including Warner Robins) generated about 115,000 tons/year of solid waste in fiscal year 1997 (July 1996 - June 1997). Most of the solid waste was disposed of in the two counties' landfills and in the privately owned Swift Creek landfill. About 50,000 tons/year of the total of 391,000 tons/year in the two counties is C/D debris. The Macon/Bibb County landfill operator said that the landfill receives a small amount of C/D debris. Tree waste (including 12,000 tons/year of Macon's yard waste) is placed in a pit from which the dirt was mined for alternate daily cover. The landfill used to grind all this wood, but stopped to save money. The landfill tipping fee is about $\$ 27.50 /$ ton.

The City of Warner Robins picks up about 7,000 tons/year of yard waste. A company in Atlanta (about 80 miles north) converts it to compost. The Houston County landfill has a 
tub grinder, and grinds some of the wood it receives from Robins Air Force Base, plus land clearing debris. Most of the ground-up wood is used as alternate daily cover at the landfill; about 4,000 tons/year of mulch are given away to the public. Based on the information above, my estimates of the amounts of wood waste entering landfills with the solid waste in the Macon-Warner Robins metropolitan area are approximately:

MSW wood: $5 \%$ of $341,000=17,000$ tons/year;

C/D wood: $20 \%$ of $50,000=10,000$ tons $/$ year.

\section{MSW Wood (Primarily Tree and Yard Wastes)}

As discussed above, an estimated 17,000 tons/year of MSW wood waste are included in the solid waste going to landfills in the area. The Macon yard waste collection program puts an estimated 12,000 tons/year into the wood pit at the Macon/Bibb County landfill. The Warner Robins yard waste recycling program produces an estimated 7,000 tons/year of mulch in Atlanta. The Houston County landfill gives away about 4,000 tons/year of mulch. None of the waste hauling companies I talked to in the Macon-Warner Robins area (including BFI and Waste Management of Macon) do any wood separation or grinding.

Georgia Power Company provides electric service to the Macon/Bibb County area, and employs about seven tree service crews (from Asplundh, Gilbert, Davey, and Burfort) to trim trees along its rights of way. Flint Electric Membership Corporation provides electric service to the Warner Robins/Houston County area, and uses three tree service crews. The total of ten crews working for the two utilities generate an estimated 10,000 tons/year of wood wastes $(3,000$ tons/year of firewood and 7,000 tons/year of mulch).

The Macon and Warner Robins Yellow Pages list 14 and 8 tree service companies, respectively, that I found to be actively doing tree service work. Based on the information these companies provided, I estimate that there are a total of about 25 crews operating in the metropolitan area, generating about 25,000 tons/year of wood from tree trimming and removals (7,000 tons/year of firewood and 18,000 tons/year of mulch).

Table 24-2 summarizes the estimated resources of MSW wood in the Macon-Warner Robins area. The total estimate, 75,000 tons/year (of which about 29,000 tons/year enter landfills), is equivalent to 0.267 tons/year/person based on the metropolitan area population of 281,103 . This is above the weighted average of 0.209 tons/year/person of MSW wood for the 30 metropolitan areas, which range from 0.134 to 0.538 tons/year/person.

Table 24-2

Resource Estimate for MSW Wood in Macon-Warner Robins, Georgia Tons/year

\begin{tabular}{|c|c|c|c|c|}
\hline & Mulch & $\begin{array}{l}\text { Fire- } \\
\text { wood }\end{array}$ & $\begin{array}{c}\text { Land- } \\
\text { fill }\end{array}$ & Total \\
\hline Hauled with trash & & & 17,000 & 17,000 \\
\hline Municipal yard waste recycl. & 11,000 & & 12,000 & 23,000 \\
\hline Utility tree trimming & 7,000 & 3,000 & & 10,000 \\
\hline Private tree service co's & 18,000 & 7,000 & & 25,000 \\
\hline Total & 36,000 & 10,000 & 29,000 & 75,000 \\
\hline
\end{tabular}




\section{Industrial Wood Wastes}

The Macon and Warner Robins Yellow Pages list a total of eight local companies under Pallets and Skids; one local company under Trusses-Construction; nine local companies under Lumber; and 22 companies under Cabinet Makers, Furniture Designers \& Custom Builders, and Furniture Manufacturers (woodworking companies). The pallet companies in the area sell most of their sawdust and wood scraps (about 5,000 tons/year) as boiler fuel to Georgia-Pacific Paper Company and others. About 500 tons/year of pallet wood scraps are given away as firewood, and about 500 tons/year are burned in rural areas.

The lumber companies in the area generate about 400 tons/year of sawdust that go to animal bedding, and about 400 tons/year of wood scraps that go to firewood. Woodworking companies in the area generate 700 tons/year or less of wood scraps that are hauled to the landfill, used by family and friends, and/or given away as firewood.

Table 24-3 summarizes the estimated resources of industrial wood wastes in the MaconWarner Robins metropolitan area. The total estimate of 7,500 tons/year is equivalent to about 0.027 tons/year/person based on the metropolitan area population of 281,103 . This is below the weighted average of 0.048 tons/year/person of industrial wood waste for the 30 metropolitan areas surveyed; the range is from 0.001 to 0.488 tons/year/person.

Table 24-3

\section{Resource Estimate for Industrial Wood Wastes in Macon-Warner Robins, Georgia Tons/year}

\begin{tabular}{|c|c|c|c|c|c|}
\hline & Biofuel & $\begin{array}{l}\text { Fire- } \\
\text { wood }\end{array}$ & $\underset{\text { Beddin }}{\text { Animal }}$ & $\begin{array}{l}\text { Land- } \\
\text { fill* }\end{array}$ & Total \\
\hline Pallet companies & 5,000 & 500 & & 500 & 6,000 \\
\hline Lumber companies & & 400 & 400 & & 800 \\
\hline Woodworking co's & & 400 & & 300 & 700 \\
\hline Total & 5,000 & 1,300 & 400 & 800 & 7,500 \\
\hline
\end{tabular}

*Landfill includes burning in rural areas.

\section{Construction/Demolition Wood Wastes}

The Macon and Warner Robins Yellow Pages list a total of four local companies under Demolition Contractors and eight companies under Land Clearing \& Leveling. Most of the $\mathrm{C} / \mathrm{D}$ debris goes to landfills. As discussed above under MSW Collection and Disposal, an estimated 10,000 tons/year of wood waste enter landfills with $\mathrm{C} / \mathrm{D}$ and land clearing debris in the Macon-Warner Robins area. In addition, an estimated 5,000 tons/year of land clearing wood are converted to saw logs, firewood, and mulch. The estimated total of 15,000 tons/year is equivalent to 0.053 tons/year/person based on the Macon-Warner Robins metropolitan area population of 281,103. This is below the weighted average of 0.076 tons/year/person of C/D wood for the 30 metropolitan areas surveyed; the range is from 0.015 to 0.250 tons/year/person. 


\section{Supply Curve}

Figure 24-1 shows the supply curve for urban wood wastes in the Macon-Warner Robins area. Table 24-4 shows the data and assumptions used to produce the supply curve.

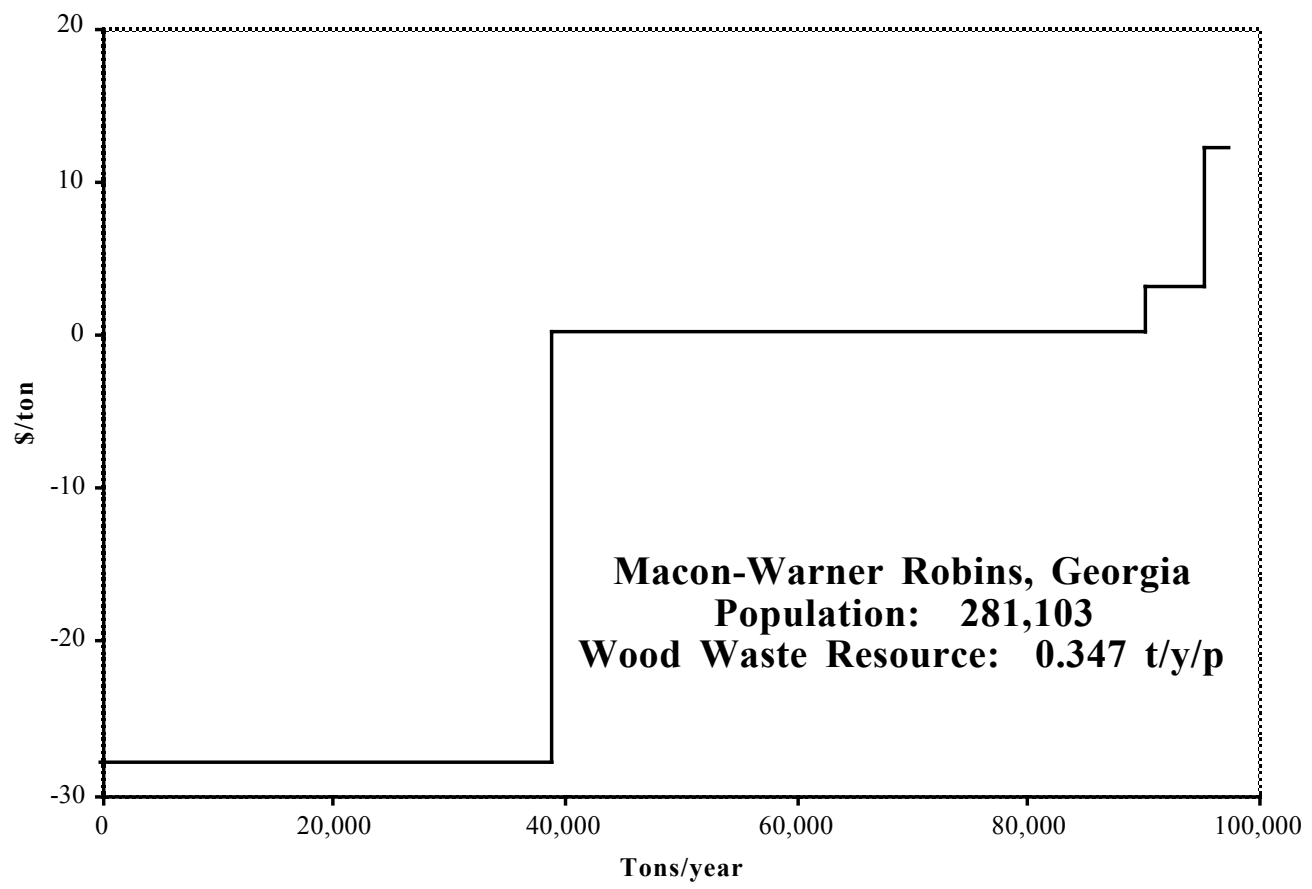

Figure 24-1. Supply Curve for Urban Wood Wastes in Macon-Warner Robins, Georgia

Table 24-4

Data and Assumptions Used in Supply Curve for Macon-Warner Robins

Tons/year Cumulative $\frac{\text { \$/ton }}{39,000}$

39,000

50,700

800

5,000

2,000

$39,000 \frac{\mathrm{s} / \mathrm{ton}}{-28}$

$89,700 \quad 0$

$90,500 \quad 0$

95,500

97,500

\section{Assumptions/Comments}

Landfilled with MSW and C/D

Firewood, mulch, animal bedding - given away

Rural dumping or burning

Biofuel - sold

12 Saw logs - sold 
Lakeland and Winter Haven are in Polk County, roughly halfway between Tampa and Orlando. The area encompasses 13 lakes, and is a processing and distribution center for citrus fruits and other agricultural products. A majority of the world's phosphate is mined in the Lakeland area. A waste fuel-fired power plant adjacent to the Polk County landfill burns about 250,000 tons/year of urban wood wastes (as well as scrap tires and landfill gas). It consumes a large portion of the wood wastes generated in the Lakeland-Winter Haven area and attracts wood wastes from other urban areas such as Tampa and Orlando.

Table 25-1 summarizes the data collected on urban wood resources in the Lakeland-Winter Haven area. The estimated total urban wood waste resource, 0.523 tons/year/person, is above the weighted average of 0.333 tons/year/person for the 30 metropolitan areas surveyed; the range for the 30 cities is from 0.156 to 0.829 tons/year/person.

\section{Table 25-1 \\ Resource Estimate for Urban Wood Waste in Lakeland-Winter Haven, Florida}

\begin{tabular}{|c|c|c|c|c|c|}
\hline \multirow[b]{2}{*}{ Use or Disposal Method: } & \multicolumn{4}{|c|}{ Tons/Year } & \multirow[b]{2}{*}{$\begin{array}{c}\text { Price, } \\
\text { S/ton }\end{array}$} \\
\hline & $\begin{array}{l}\text { MSW } \\
\text { Wood }\end{array}$ & $\begin{array}{l}\text { Industr. } \\
\text { Wood }\end{array}$ & $\begin{array}{c}\text { C/D } \\
\text { Wood }\end{array}$ & Total & \\
\hline Firewood & 3,000 & 1,000 & & 4,000 & 0 \\
\hline Mulch (ground cover) & 27,000 & 35,500 & & 62,500 & 0 \\
\hline Animal bedding & & 3,000 & & 3,000 & 0 \\
\hline Biomass fuel & 91,000 & 6,500 & & 97,500 & -5 to -13 \\
\hline Landfill or incineration & 17,000 & & 28,000 & 45,000 & -15 to -44 \\
\hline Total & 138,000 & 46,000 & 28,000 & 212,000 & \\
\hline Total, tons/year/person & 0.340 & 0.113 & 0.069 & 0.523 & \\
\hline
\end{tabular}

\section{Municipal Solid Waste (MSW) Collection and Disposal}

Polk County owns and operates two class 1 landfills and one C/D landfill. The following amounts of solid waste were disposed of in these landfills in fiscal year 10/1/96-9/30/97: 148,923 tons residential; 158,607 tons commercial; and 29,920 tons of C/D debris. About 41,400 tons of brush were collected and sent as fuel to the Wheelabrator Ridge Energy plant. The Polk County landfills charge tipping fees of $\$ 44 /$ ton for household garbage and $\$ 25 /$ ton for yard waste or C/D debris. The City of Lakeland operates the $300 \mathrm{MW}$ McIntosh coal-fired power plant, designed to cofire refuse-derived fuel (RDF) along with the coal. The McIntosh plant consumed about 38,000 tons/year of RDF in FY1996-97.

The BFI Cedar Trails Landfill in Polk County has a class 3 permit, which allows disposal of C/D debris plus items like carpet, paper, and glass. This landfill receives about 108,000 tons/year of solid waste, mostly C/D debris. About 10,000 tons/year of clean wood waste are ground at the BFI landfill; most of this material goes to the Wheelabrator Ridge Energy plant. The BFI landfill gate rates are $\$ 15 /$ ton for C/D debris, $\$ 18 /$ ton for yard waste, and $\$ 20 /$ ton for class 3 materials. Based on the information above, my estimates of the amounts of wood waste entering landfills and the McIntosh power plant with the solid waste in the Lakeland-Winter Haven area are approximately:

MSW wood: $5 \%$ of $345,000=17,000$ tons $/$ year; 
C/D wood: $20 \%$ of $138,000=28,000$ tons/year.

\section{MSW Wood (Primarily Tree and Yard Wastes)}

Most of the yard waste in the metropolitan area (about 51,000 tons/year) goes to the Wheelabrator Ridge Energy plant. Other than BFI, which grinds about 10,000 tons/year of wood at its Cedar Woods landfill, none of the waste hauling companies I talked to in the area (including Waste Management of Tampa) do any wood separation or grinding. BFI takes pallet loads, as well as the wood ground at its landfill, to Wheelabrator Ridge Energy.

The Wheelabrator Ridge Energy plant is located near Auburndale (between Lakeland and Winter Haven), adjacent to the Polk County North Central landfill. The unit has a gross capacity of $45 \mathrm{MW}$ and nets about $40 \mathrm{MW}$ in sales to the City of Lakeland. It is designed to burn waste wood, waste tires, and landfill gas. The facility receives waste wood and tires from local haulers and communities; tipping fees for wood wastes are approximately $\$ 5 /$ ton for clean chips or logs, and $\$ 12.50 /$ ton for brush, limbs, etc. The tipping fee for tires is about $\$ 60 /$ ton. The plant processes about 250,000 tons/year of waste wood and nearly 30,000 tons/year of scrap tires. The plant's design and air quality permit allow it to burn any type of wood, including treated wood.

The Lakeland Electric \& Water Utilities Department employs about 15 contract tree service crews to keep its rights of way clear. Most of the 15,000 tons/year of wood generated by this tree trimming activity are ground up and given away as mulch. About 600 tons of large tree pieces and 63 tons of utility poles were taken to the Wheelabrator Ridge Energy plant in 1997. Tampa Electric Company provides electric service to Winter Haven and employs about five tree service crews, generating about 5,000 tons/year of mulch.

The Lakeland/Winter Haven Yellow Pages list 42 tree service companies; about 50 crews generate about 50,000 tons/year of wood from tree trimming and removals. A large percentage of this wood goes to Wheelabrator Ridge Energy; about 40,000 tons/year go to biofuel, about 3,000 tons/year go to firewood, and about 7,000 tons/year go to mulch.

Table 25-2 summarizes the estimated resources of MSW wood in the Lakeland-Winter Haven area. The total estimate, 138,000 tons/year (of which about 17,000 tons/year enter waste facilites), is equivalent to 0.340 tons/year/person based on the area population of 405,382. This is above the weighted average of 0.209 tons/year/person of MSW wood for the 30 metropolitan areas, which range from 0.134 to 0.538 tons/year/person.

\section{Table 25-2 \\ Resource Estimate for MSW Wood in Lakeland-Winter Haven, Florida Tons/year}

\begin{tabular}{|c|c|c|c|c|c|}
\hline & Biofuel & Mulch & $\begin{array}{l}\text { Fire- } \\
\text { wood }\end{array}$ & $\begin{array}{l}\text { Land- } \\
\text { fill* }\end{array}$ & Total \\
\hline Hauled with trash & & & & 17,000 & 17,000 \\
\hline Municipal yard waste recycl. & 51,000 & & & & 51,000 \\
\hline Utility tree trimming & & 20,000 & & & 20,000 \\
\hline Private tree service co's & 40,000 & 7,000 & 3,000 & & 50,000 \\
\hline Total & 91,000 & 27,000 & 3,000 & 17,000 & 138,000 \\
\hline
\end{tabular}

*“Landfill” includes RDF burned in the McIntosh power plant. 


\section{Industrial Wood Wastes}

The Lakeland-Winter Haven Yellow Pages list eight companies under Pallets and Skids; three companies under Trusses-Construction; six companies under Lumber-Wholesale; six companies under Lumber-Retail; and 39 companies under Cabinet Makers, Furniture Designers \& Custom Builders, and Furniture Manufacturers (woodworking companies). Five of the pallet companies grind up about 32,000 tons/year of pallet wood waste and sell it as mulch. In some cases (included in the above estimate) they deliver their wood scraps to a company called Southern Softwoods Inc. who produces and sells the mulch. Four pallet companies take about 6,000 tons/year of wood scraps to Wheelabrator Ridge Energy. One pallet/lumber company sells about 2,000 tons/year of animal bedding.

Only one of the three truss companies reported producing a significant amount of wood waste. They have about 500 tons/year of wood scraps picked up by Southern Softwoods Inc., who produces and sells mulch. Wholesale lumber companies in the area generate about 3,000 tons/year of mulch, and about 1,000 tons/year of animal bedding. Retail lumber companies in the area generate about 500 tons/year of wood scraps that go to firewood. Woodworking companies produce 1,000 tons/year or less of wood scraps that are hauled to the landfill, Wheelabrator Ridge Energy plant, or given away as firewood.

Table 25-3 summarizes the estimated resources of industrial wood wastes in the LakelandWinter Haven metropolitan area. The total estimate of 46,000 tons/year is equivalent to about 0.113 tons/year/person based on the metropolitan area population of 405,382 . This is above the weighted average of 0.048 tons/year/person of industrial wood waste for the 30 metropolitan areas surveyed; the range is from 0.001 to 0.488 tons/year/person.

\section{Table 25-3 \\ Resource Estimate for Industrial Wood Wastes in Lakeland-Winter Haven, Florida Tons/year}

\begin{tabular}{|c|c|c|c|c|c|}
\hline & Mulch & Biofuel & $\begin{array}{l}\text { Animal } \\
\text { Beddin }\end{array}$ & $\begin{array}{l}\text { Fire- } \\
\text { wood }\end{array}$ & Total \\
\hline Pallet companies & 32,000 & 6,000 & 2,000 & & 40,000 \\
\hline Truss companies & 500 & & & & 500 \\
\hline Whlsl lumber co's & 3,000 & & 1,000 & & 4,000 \\
\hline Retail lumber co's & & & & 500 & 500 \\
\hline Woodworking co's & & 500 & & 500 & 1,000 \\
\hline Total & 35,500 & 6,500 & 3,000 & 1,000 & 46,000 \\
\hline
\end{tabular}

\section{Construction/Demolition Wood Wastes}

The Lakeland-Winter Haven Yellow Pages list six local companies under Demolition Contractors and ten companies under Land Clearing \& Leveling. All of these companies reported that they take all of their debris to C/D landfills. As discussed above under MSW Collection and Disposal, an estimated 28,000 tons/year of wood waste enter landfills with $\mathrm{C} / \mathrm{D}$ and land clearing debris in the Lakeland-Winter Haven area. The estimated total of 28,000 tons/year is equivalent to 0.069 tons/year/person based on the Lakeland-Winter Haven metropolitan area population of 405,382. This is below the weighted average of 0.076 tons/year/person of $\mathrm{C} / \mathrm{D}$ wood for the 30 metropolitan areas surveyed; the range is from 0.015 to 0.250 tons/year/person. 


\section{Supply Curve}

Figure 25-1 shows the supply curve for urban wood wastes in the Lakeland-Winter Haven area. Table 25-4 shows the data and assumptions used to produce the supply curve.

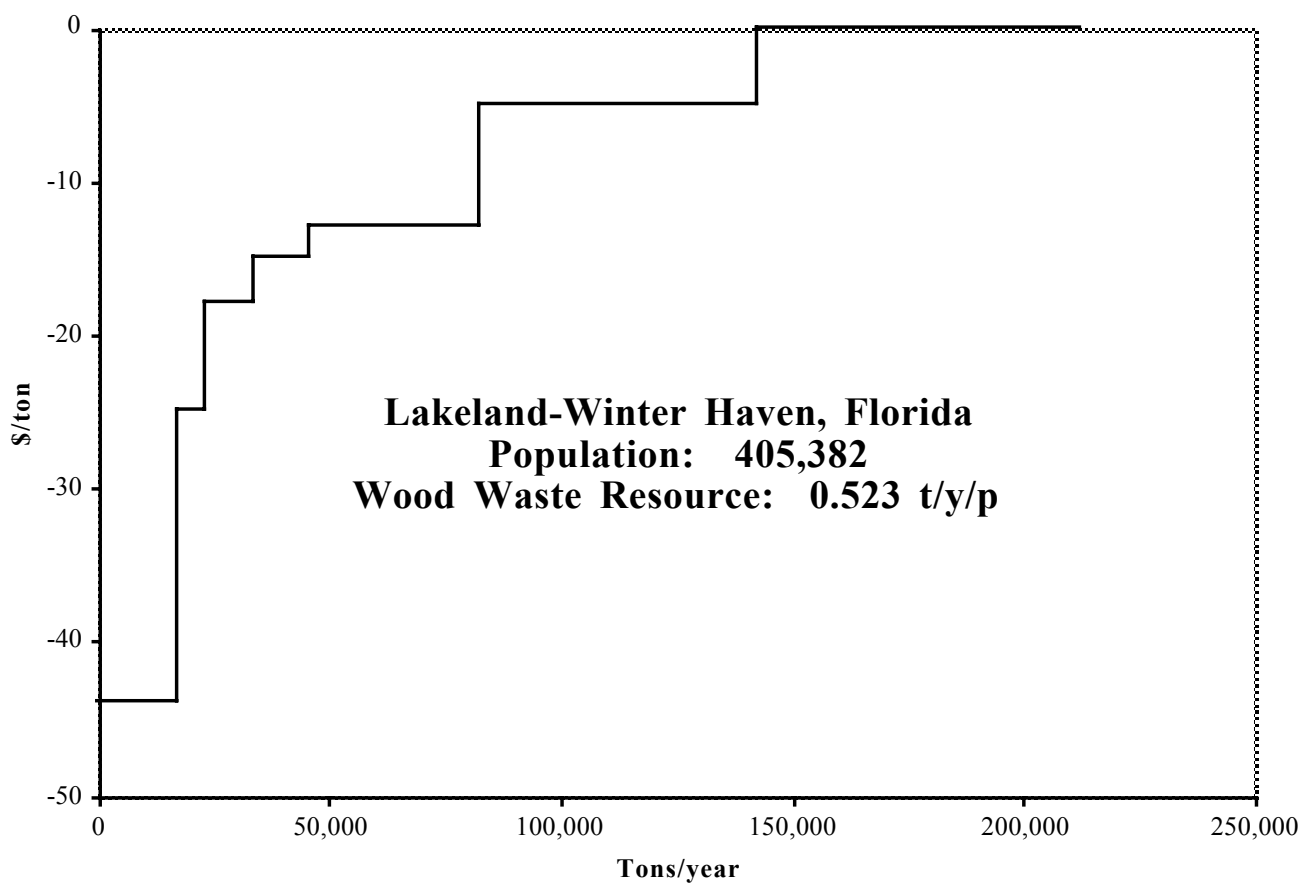

Figure 25-1. Supply Curve for Urban Wood Wastes in Lakeland-Winter Haven, Florida

Table 25-4

Data and Assumptions Used in Supply Curve for Lakeland-Winter Haven

Tons/year Cumulative \$/ton

$17,000 \frac{17,000}{-44}$

Assumptions/Comments

$6,400 \quad 23,400 \quad-25$ Landfilled with C/D - county landfill

$10,000 \quad 33,400 \quad-18 \quad$ Private landfill - yard waste processed

$11,600 \quad 45,000 \quad-15 \quad$ Landfilled with C/D - private landfill

$37,500 \quad 82,500 \quad-13 \quad$ Biopower plant - tipping fee

$60,000 \quad 142,500 \quad-5 \quad$ Biopower plant - tipping fee

$69,500 \quad 212,000 \quad 0 \quad$ Firewood, mulch, animal bedding - given away 
Bradenton is on Florida's west coast, south of Tampa and north of Sarasota, in Manatee County. The Manatee River empties into a large bay that forms Bradenton's northern boundary. There are no large industries in Bradenton. The Bradenton Yellow Pages include listings for many businesses in Sarasota, which is a separate metropolitan area. I did not include any of the Sarasota-based businesses in the data collection effort.

Table 26-1 summarizes the data collected on urban wood resources in the Bradenton area. The estimated total urban wood waste resource, 0.654 tons/year/person, is well above the weighted average of 0.333 tons/year/person for the 30 metropolitan areas surveyed; the range for the 30 cities is from 0.156 to 0.829 tons/year/person. The Bradenton area has a high biomass growth rate that produces a large amount of MSW wood waste. The Manatee County landfill has a wood grinding yard. In addition to the city and county, tree service companies and industrial wood waste generators haul wood wastes to this facility. Any mulch that cannot be used in landscaping projects by the city and county is the contractor's to dispose of, and the primary outlet is as boiler fuel at Wheelabrator Ridge Energy near Lakeland, where the same contractor operates in the fuel yard. A biomass energy project in the Bradenton area could capture most of this wood waste (plus more from Tampa, St. Petersburg, and Sarasota). About 50,000-100,000 tons/year of wood waste appear to be available in the Bradenton metropolitan area, enough to generate 3 to $10 \mathrm{MW}$ of electricity.

Table 26-1

Resource Estimate for Urban Wood Waste in Bradenton, Florida

\begin{tabular}{|c|c|c|c|c|c|}
\hline \multirow[b]{2}{*}{ Use or Disposal Method: } & \multicolumn{4}{|c|}{ Tons/Year } & \multirow[b]{2}{*}{$\begin{array}{c}\text { Price, } \\
\text { \$/ton }\end{array}$} \\
\hline & $\begin{array}{l}\text { MSW } \\
\text { Wood }\end{array}$ & $\begin{array}{c}\text { Industr. } \\
\text { Wood }\end{array}$ & $\begin{array}{c}\text { C/D } \\
\text { Wood }\end{array}$ & Total & \\
\hline Firewood & 1,500 & 300 & & 1,800 & 0 \\
\hline Animal bedding & & 200 & & 200 & 0 \\
\hline Mulch* & 94,500 & 4,000 & 7,000 & 105,500 & 0 to -23 \\
\hline Landfill & 18,000 & & 13,000 & 31,000 & -23 \\
\hline Total & 14,000 & 4,500 & 20,000 & 138,500 & \\
\hline Total, tons/year/person & 0.538 & 0.021 & 0.094 & 0.654 & \\
\hline
\end{tabular}

*Excess mulch is disposed of as boiler fuel.

\section{Municipal Solid Waste (MSW) Collection and Disposal}

Manatee County collects all of the solid waste generated in the city and county and disposes of it at the county landfill. Separate yard waste collection is mandatory. The total amount of solid waste collected in 1977 was 505,399 tons, of which 148,051 tons were recycled and 357,348 tons were landfilled. Included in the recycled material were about 70,000 tons/year of yard waste, which were processed through a tub grinder and trommel screen at the landfill. The fines were used in the landfill as alternate daily cover, and the mulch was used by the city and county for landscaping at schools, parks, etc. C/D debris goes into a separate cell at the landfill (66,824 tons/year). The landfill tipping fee is $\$ 23 /$ ton for solid waste originating inside the county; for tires, the tipping fee is $\$ 72 /$ ton. Based on the information above, my estimates of the amounts of wood waste entering landfills along with the solid waste in the Bradenton metropolitan area are approximately: 
MSW wood: $5 \%$ of $357,000=18,000$ tons/year;

C/D wood: $20 \%$ of $67,000=13,000$ tons/year.

\section{MSW Wood (Primarily Tree and Yard Wastes)}

As discussed above, an estimated 18,000 tons/year of MSW wood waste are included in the solid waste going to the landfill. Most of the yard waste in the area (about 70,000 tons/year) is converted to mulch and used in city/county landscaping projects. None of the waste hauling companies I talked to in the Bradenton area (including BFI and Waste Management of Manatee County) do any wood separation or grinding.

Consolidated Resource Recovery Inc. in Bradenton is a wood grinding contractor that grinds yard wastes and tree wastes at the county landfill and for various municipalities in the area, as well as many other parts of Florida. Statewide, Consolidated Resource Recovery processes about 750,000 tons/year of wood wastes, including the wood received at the Wheelabrator Ridge Energy plant (see Lakeland-Winter Haven). The company does not have any wood processing yards; it is strictly a mobile, on-site operation. It gets paid by the ton of wood processed, and is responsible for disposal of the resulting product to the extent that the customers do not use it themselves.

Florida Power \& Light provides electric service to Manatee County and the city of Bradenton, and employs about six contract tree service crews to keep its rights of way clear. About 5,500 tons/year of mulch and about 500 tons/year of firewood generated by this tree trimming activity are given away to property owners or to others who want it.

The Bradenton Yellow Pages list 17 tree service companies that I found to be actively doing tree service work. About 20 crews operate in the metropolitan area, generating about 20,000 tons/year of wood from tree trimming and removals. A large percentage of this wood is hauled to the landfill where it is ground to mulch along with the county yard waste. About 1,000 tons/year go to firewood and about 19,000 tons/year go to mulch.

Table 26-2 summarizes the estimated resources of MSW wood in the Bradenton area. The total estimate, 114,000 tons/year (of which about 18,000 tons/year enter the landfill), is equivalent to 0.538 tons/year/person based on the metropolitan area population of 211,707 . This is the highest per capita estimate for MSW wood for the 30 metropolitan areas, which range from 0.134 to 0.538 and average 0.209 tons/year/person.

Table 26-2

Resource Estimate for MSW Wood in Bradenton, Florida Tons/year

\begin{tabular}{|c|c|c|c|c|}
\hline & Mulch* & $\begin{array}{l}\text { Fire- } \\
\text { wood }\end{array}$ & $\begin{array}{c}\text { Land- } \\
\text { fill }\end{array}$ & Total \\
\hline Hauled with trash & & & 18,000 & 18,000 \\
\hline Municipal yard waste recycl. & 70,000 & & & 70,000 \\
\hline Utility tree trimming & 5,500 & 500 & & 6,000 \\
\hline Private tree service co's & 19,000 & 1,000 & & 20,000 \\
\hline Total & 94,500 & 1,500 & 18,000 & 114,000 \\
\hline
\end{tabular}

*Excess mulch is disposed of as boiler fuel. 


\section{Industrial Wood Wastes}

The Bradenton Yellow Pages list one local company under Pallets and Skids; one local company under Trusses-Construction; two local companies under Lumber-Wholesale; three local companies under Lumber-Retail; and 48 companies under Cabinet Makers, Furniture Designers \& Custom Builders, and Furniture Manufacturers (woodworking companies). The one local pallet company in the Bradenton area hauls about four trailers per week (about 4,000 tons/year) of waste wood to the county landfill, where it is ground and ends up either as mulch or boiler fuel. The two local truss companies and the two local wholesale lumber companies generate about 200 tons/year of animal bedding.

The retail lumber companies in the Bradenton area generate about 100 tons/year of small wood scraps that go to firewood. Woodworking companies in the area generate 200 tons/year or less of wood scraps that are hauled to the landfill, used by family and friends, and/or given away as firewood.

Table 26-3 summarizes the estimated resources of industrial wood wastes in the Bradenton metropolitan area. The total estimate of 4,500 tons/year is equivalent to about 0.021 tons/year/person based on the Bradenton metropolitan area population of 211,707. This is below the weighted average of 0.048 tons/year/person of industrial wood waste for the 30 metropolitan areas surveyed; the range is from 0.001 to 0.488 tons/year/person.

Table 26-3

\section{Resource Estimate for Industrial Wood Wastes in Bradenton, Florida Tons/year}

\begin{tabular}{|c|c|c|c|c|}
\hline & Mulch* & $\begin{array}{l}\text { Animal } \\
\text { Beddin }\end{array}$ & $\begin{array}{l}\text { Fire- } \\
\text { wood }\end{array}$ & Total \\
\hline Pallet companies & 4,000 & & & 4,000 \\
\hline $\begin{array}{l}\text { Truss \& wholesale lumber } \\
\text { co's }\end{array}$ & & 200 & & 200 \\
\hline Retail lumber co's & & & 100 & 100 \\
\hline Woodworking co's & & & 200 & 200 \\
\hline Total & 4,000 & 200 & 300 & 4,500 \\
\hline
\end{tabular}

*Excess mulch is disposed of as boiler fuel.

\section{Construction/Demolition Wood Wastes}

The Bradenton Yellow Pages list two local companies under Demolition Contractors and 12 companies under Land Clearing \& Leveling. Most of these companies reported that they take all of their debris to C/D landfills. Some of the land clearing companies have Consolidated Resource Recovery Inc. come onsite and grind up trees and stumps. As discussed above under MSW Collection and Disposal, an estimated 13,000 tons/year of wood waste enter landfills with $\mathrm{C} / \mathrm{D}$ and land clearing debris in the Bradenton area. In addition, I estimate that another 7,000 tons/year are ground on land clearing sites and end up as mulch or boiler fuel. The estimated total of 20,000 tons/year is equivalent to 0.094 tons/year/person based on the Bradenton metropolitan area population of 211,707. This is above the weighted average of 0.076 tons/year/person of C/D wood for the 30 metropolitan areas surveyed; the range is from 0.015 to 0.250 tons/year/person. 


\section{Supply Curve}

Figure 26-1 shows the supply curve for urban wood wastes in the Bradenton area. Table 26-4 shows the data and assumptions used to produce the supply curve.

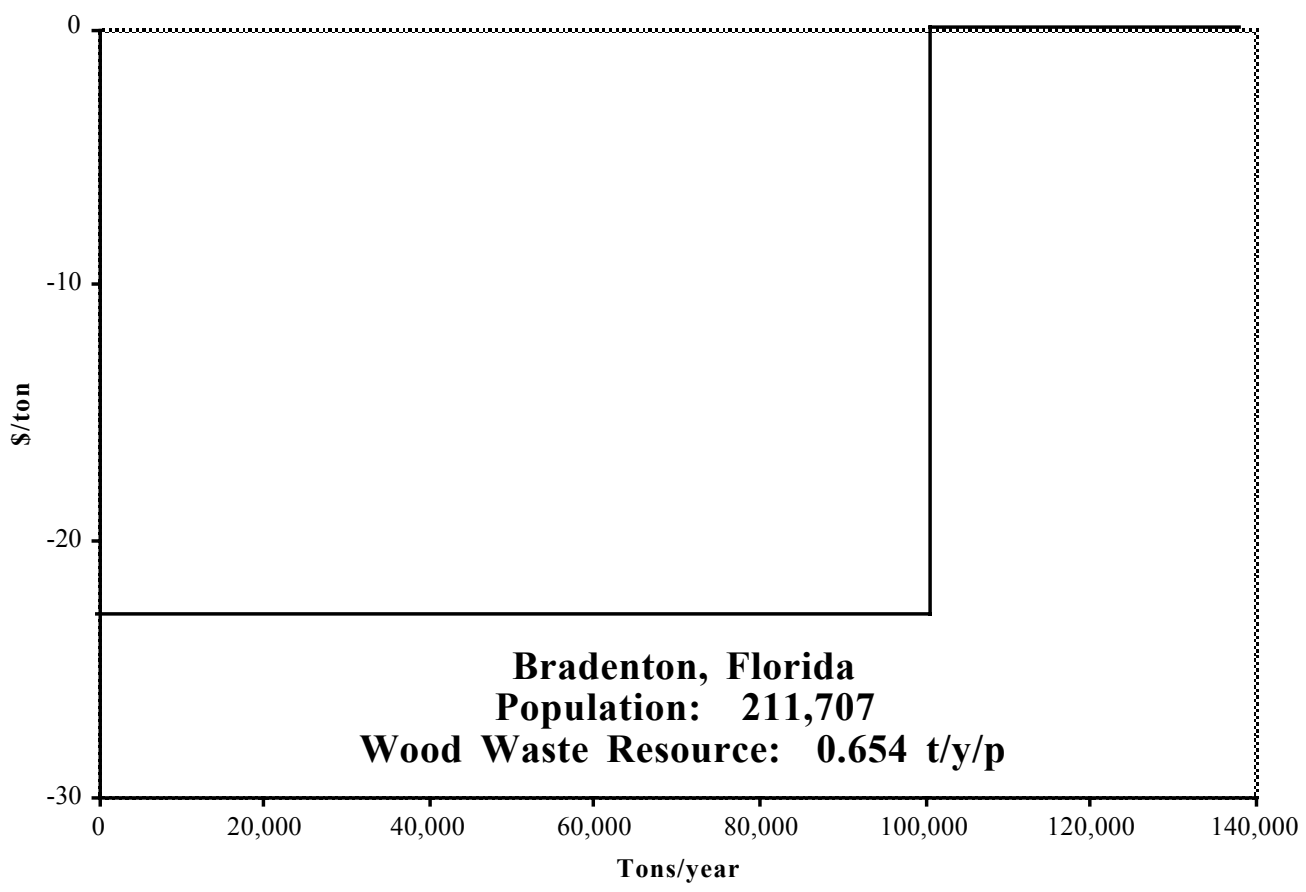

Figure 26-1. Supply Curve for Urban Wood Wastes in Bradenton, Florida

Table 26-4

Data and Assumptions Used in Supply Curve for Bradenton

Tons/year Cumulative $\frac{\text { \$/ton }}{31,000}$ Assumptions/Comments

31,000

70,000

37,500
31,000

101,000

138,500

\section{$-23$}

$-23$

Landfilled with MSW and C/D - county landfill

Yard waste processed at county landfill

Firewood, mulch, animal bedding - given away 
Baton Rouge is the state capital and second largest city in Louisiana, and one of the largest ports in the nation. It lies on the east bank of the Mississippi River in East Baton Rouge Parish; West Baton Rouge and West Baton Rouge Parish are across the river. Baton Rouge is at the northern end of the petrochemical and industrial belt that flanks the Mississippi for 100 miles downriver to New Orleans. Across the river from Baton Rouge great sugar plantations form an area known as the "Sugar Bowl of America." Baton Rouge has two major universities: Louisiana State University and Southern University.

Table 27-1 summarizes the data collected on urban wood resources in the Baton Rouge area. The estimated total urban wood waste resource, 0.490 tons/year/person, is above the weighted average of 0.333 tons/year/person for the 30 metropolitan areas surveyed; the range for the 30 cities is from 0.156 to 0.829 tons/year/person. The area has one wood processing company, but the demand for its products is very low compared to the supply, and the company's primary activity is on-site incineration of land clearing wood debris. Baton Rouge has a relatively low level of industrial wood waste generation. A biomass energy project might be able to obtain 150,000-200,000 tons/year of MSW and C/D wood at a relatively low cost, and produce 10-20 MW of electricity.

Table 27-1

Resource Estimate for Urban Wood Waste in Baton Rouge, Louisiana

Tons/Year

\begin{tabular}{|c|c|c|c|c|c|}
\hline Use or Disposal Method: & $\begin{array}{l}\text { MSW } \\
\text { Wood }\end{array}$ & $\begin{array}{c}\text { Industr. } \\
\text { Wood }\end{array}$ & $\begin{array}{c}\text { C/D } \\
\text { Wood }\end{array}$ & Total & $\begin{array}{l}\text { Price, } \\
\text { \$/ton }\end{array}$ \\
\hline Mulch (ground cover) & 43,000 & & & 43,000 & 0 \\
\hline Animal bedding & & 4,600 & & 4,600 & 0 \\
\hline Firewood & 8,000 & 1,200 & & 9,200 & 0 \\
\hline Rural dumping or burning & 33,000 & & 20,000 & 53,000 & 0 \\
\hline Saw logs or pulp chips & 4,000 & & 5,000 & 9,000 & -14 to -19 \\
\hline Biomass fuel & 2,000 & & & 2,000 & -14 to -19 \\
\hline Landfill or incineration & 73,000 & 5,200 & 60,000 & 138,200 & -14 to -28 \\
\hline Total & 163,000 & 11,000 & 85,000 & 259,000 & \\
\hline Total, tons/year/person & 0.309 & 0.021 & 0.161 & 0.490 & \\
\hline
\end{tabular}

\section{Municipal Solid Waste (MSW) Collection and Disposal}

The State of Louisiana Department of Environmental Quality, Office of Solid Waste, provided the following solid waste disposal statistics for the three landfills in the Baton Rouge area for the fiscal year that ended June 30, 1997, in tons/year:

\begin{tabular}{|c|c|c|c|c|}
\hline Landfill: & Baton Rouge & BFI Colonial & WM Woodside & Total \\
\hline Residential & 154,884 & 15,651 & 77,086 & 247,621 \\
\hline Commercial & 102,102 & 108,756 & 249,379 & 460,237 \\
\hline Trash & 136,483 & 10,224 & 2,889 & 149,596 \\
\hline Total MSW & 393,469 & 134,631 & 329,354 & 857,454 \\
\hline $\mathrm{C} / \mathrm{D}$ debris & 21,029 & 2,364 & 715 & 24,108 \\
\hline
\end{tabular}


The Baton Rouge North landfill is owned by the city parish government and operated by the Public Works Department; the other two landfills are privately owned (Colonial by BFI and Woodside by Waste Management Inc.). "Trash" apparently refers to self-hauled municipal solid waste. The MSW disposed of at the three landfills, over 857,000 tons/year, likely includes solid waste from outside the Baton Rouge metropolitan area; it is equivalent to over 1.6 tons/year/person, which is about twice the EPA national average per capita solid waste generation rate. The landfill tipping fees are \$20/ton at the Baton Rouge North landfill (\$25/ton for waste originating outside the parish); $\$ 27.50 /$ ton at the Woodside landfill; and $\$ 8.25 /$ cubic yard at the Colonial landfill. The latter is equivalent to about $\$ 27 /$ ton for wood chips.

Baton Rouge is in the startup phase of a yard waste collection program. Presently about 6,000 tons/year of yard waste are being collected and delivered to a contractor, Total Wood Recycling Services, Inc. (discussed below). Studies by the city's recycling office have estimated that about 30,000 to 40,000 tons/year of yard waste are generated in the city, most of which is currently entering landfills. Based on the information above, my estimates of the amounts of wood waste entering landfills along with the solid waste in the Baton Rouge metropolitan area are approximately:

MSW wood: $5 \%$ of $857,000=43,000$ tons/year, plus about 30,000 tons/year of yard waste that is not currently collected separately; total $=73,000$ tons/year;

C/D wood: $20 \%$ of $24,000=5,000$ tons/year.

\section{MSW Wood (Primarily Tree and Yard Wastes)}

As discussed above, an estimated 73,000 tons/year of MSW wood waste are included in the solid waste going to landfills in the Baton Rouge area. None of the waste hauling companies (including BFI and Waste Management of Baton Rouge) separate or grind wood. BFI stated that they do have a few customers (e.g., pallet companies) that generate loads of clean wood. BFI takes these loads to Total Wood Recycling Services, Inc., who accepts all kinds of wood waste (trees, limbs, brush, stumps, pallets, woodworking waste, etc.), except wood that is chemically treated or contaminated. Some of the wood is ground to mulch and boiler fuel, and some is incinerated using a technique called "Air Curtain Incineration". Total Wood Recycling charges a tipping fee of $\$ 18.50 /$ ton of wood brought to its facilities. The company operates three wood processing yards around the Baton Rouge area. The company also operates at customers' job sites -- incinerating trees and stumps at land clearing sites, for example. Fees for these jobs are submitted on a competitive bid basis, and are typically about $\$ 14.50 /$ ton of wood.

During 1997, Total Wood Recycling processed 6,799 tons of residential wood waste and 6,073 tons of commercial wood waste at its three yards $(12,872$ tons/year total). Most of the commercial wood waste is from tree service companies $(5,000$ tons/year or more); the remainder (500-1,000 tons/year) is industrial wood wastes, primarily pallets. Total Wood Recycling produced the following products from this wood waste in 1997, in tons/year:

\begin{tabular}{lr} 
Pulpwood & 1,531 \\
Firewood & 772 \\
Wood chips (fuel) & 2,074 \\
Saw logs & 2,941 \\
Pallets/lumber & 370 \\
Mix & 1,304 \\
Mulch & 912 \\
Wood ash & 158 \\
\cline { 2 - 2 } Total & 10,063
\end{tabular}


The difference between the wood waste input and output totals (about 2,809 tons/year) is due to weight loss (drying) and incineration, as well as some inventory change. The company owner did not give me similar accounting records on the incineration of wood wastes at customers' job sites, but he mentioned a figure of about 55,000 tons/year. This would be essentially all in the land clearing wood waste category.

Entergy (Gulf States Utilities) provides electric service to the city of Baton Rouge. Entergy employs 26 contract tree service crews (Nelson Tree Company, based in Ohio) in the area from Lafayette to Baton Rouge, and 43 crews in the area from Hammond to Brouillette, to keep its rights of way clear. About half of these crews (say 34) are actually in the Baton Rouge metropolitan area. Most of the 34,000 tons/year of wood generated by this tree trimming activity is ground to mulch or cut to firewood length and given away, either to the property owners or to companies and people that want it. My estimate is 30,000 tons/year of mulch and 4,000 tons/year of firewood. The Entergy Forestry Operations manager said that some mulch that cannot be given away is dumped at approved dump sites.

The Baton Rouge Yellow Pages list 42 tree service companies that I found to be actively doing tree service work. About 50 crews operate in the metropolitan area, generating about 50,000 tons/year of wood from tree trimming and removals. About 5,000 tons/year of this wood goes to Total Wood Recycling where it is processed into the products discussed above; about three out of every four tree service companies I interviewed took some wood there. The rest is disposed of by giving away mulch and firewood, and by rural dumping and burning. My estimate is that about 33,000 tons/year are dumped or burned in rural areas, about 2,000 tons/year end up as saw logs or pulp chips, about 1,000 tons/year go to biofuel, about 4,000 tons/year go to firewood, and about 10,000 tons/year go to mulch.

Table 27-2 summarizes the estimated resources of MSW wood in the Baton Rouge metropolitan area. The total estimate, 163,000 tons/year (of which about 106,000 tons/year enter landfills or are dumped or burned in rural areas), is equivalent to 0.309 tons/year/person based on the metropolitan area population of 528,264. This is above the weighted average of 0.209 tons/year/person of MSW wood for the 30 metropolitan areas, which range from 0.134 to 0.538 tons/year/person.

\section{Table 27-2 \\ Resource Estimate for MSW Wood in Baton Rouge, Louisiana Tons/year}

\begin{tabular}{|c|c|c|c|c|c|}
\hline & Mulch & $\begin{array}{c}\text { To } \\
\text { Mills* }\end{array}$ & $\begin{array}{l}\text { Fire- } \\
\text { wood }\end{array}$ & $\begin{array}{l}\text { Land- } \\
\text { fill** }\end{array}$ & Total \\
\hline Hauled with trash & & & & 73,000 & 73,000 \\
\hline Municipal yard waste recycl. & 3,000 & 3,000 & & & 6,000 \\
\hline Utility tree trimming & 30,000 & & 4,000 & & 34,000 \\
\hline Private tree service co's & 10,000 & 3,000 & 4,000 & 33,000 & 50,000 \\
\hline Total & 43,000 & 6,000 & 8,000 & 106,000 & 163,000 \\
\hline
\end{tabular}

*"To Mills" includes saw logs and pulp chips (2,000 tons/year), and biofuel (1,000 tons/year).

**“Landfill” includes rural dumping or burning (about 33,000 tons/year). 


\section{Industrial Wood Wastes}

The Baton Rouge Yellow Pages list four companies under Pallets and Skids; no companies under Trusses-Construction; two companies under Lumber-Wholesale; 24 under LumberRetail; and 56 companies under Cabinet Makers, Furniture Designers \& Custom Builders, and Furniture Manufacturers (woodworking companies). The pallet companies in the Baton Rouge area incinerate most of their wood wastes. One small company puts some of its wood waste in the dumpster. One company gives its sawdust away as animal bedding and incinerates its wood scraps. My estimates are 5,000 tons/year incinerated and 2,000 tons/year given away as animal bedding.

One of the wholesale lumber companies in the Baton Rouge area generates about 2,000 tons/year of sawdust, which it sells for animal bedding. The other wholesale lumber company is a broker who does no cutting and generates no wood waste. The retail lumber companies in the Baton Rouge area generate about 1,000 tons/year of small wood scraps that go to firewood. Woodworking companies in the area generate about 600 tons/year of animal bedding, 200 tons/year of firewood, and 200 tons/year to the landfill.

Table 27-3 summarizes the estimated resources of industrial wood wastes in the Baton Rouge area. The total estimate of 11,000 tons/year is equivalent to about 0.021 tons/year/person based on the metropolitan area population of 528,264. This is below the weighted average of 0.048 tons/year/person of industrial wood waste for the 30 metropolitan areas surveyed; the range is from 0.001 to 0.488 tons/year/person.

Table 27-3

\section{Resource Estimate for Industrial Wood Wastes in Baton Rouge, Louisiana Tons/year}

\begin{tabular}{|c|c|c|c|c|}
\hline & $\begin{array}{c}\text { Incin. or } \\
\text { Landfill } \\
\end{array}$ & $\begin{array}{l}\text { Animal } \\
\text { Beddin }\end{array}$ & $\begin{array}{l}\text { Fire- } \\
\text { wood }\end{array}$ & Total \\
\hline Pallet companies & 5,000 & 2,000 & & 7,000 \\
\hline Whlsl lumber co's & & 2,000 & & 2,000 \\
\hline Retail lumber co's & & & 1,000 & 1,000 \\
\hline Woodworking co's & 200 & 600 & 200 & 1,000 \\
\hline Total & 5,200 & 4,600 & 1,200 & 11,000 \\
\hline
\end{tabular}

\section{Construction/Demolition Wood Wastes}

The Baton Rouge Yellow Pages list eight local companies under Demolition Contractors and 14 companies under Land Clearing \& Leveling. All of the demolition contractors reported that they take their debris to C/D landfills. As discussed above under MSW Collection and Disposal, an estimated 5,000 tons/year of wood waste enters landfills with $\mathrm{C} / \mathrm{D}$ debris in the Baton Rouge area. The land clearing companies recover saw logs to the extent possible and burn the wood debris or have it incinerated on site by Total Wood Recycling Services, Inc. Total Wood Recycling gave me a rough estimate of about 55,000 tons/year of land clearing wood incinerated. I assumed that land clearing companies sell about 5,000 tons/year of saw logs, and burn about 20,000 tons/year of wood debris.

The estimated total of 85,000 tons/year is equivalent to 0.161 tons/year/person based on the Baton Rouge metropolitan area population of 528,264. This is above the weighted average 
of 0.076 tons/year/person of C/D wood for the 30 metropolitan areas surveyed; the range is from 0.015 to 0.250 tons/year/person.

\section{Supply Curve}

Figure 27-1 shows the supply curve for urban wood wastes in the Baton Rouge area. Table 27-4 shows the data and assumptions used to produce the supply curve.

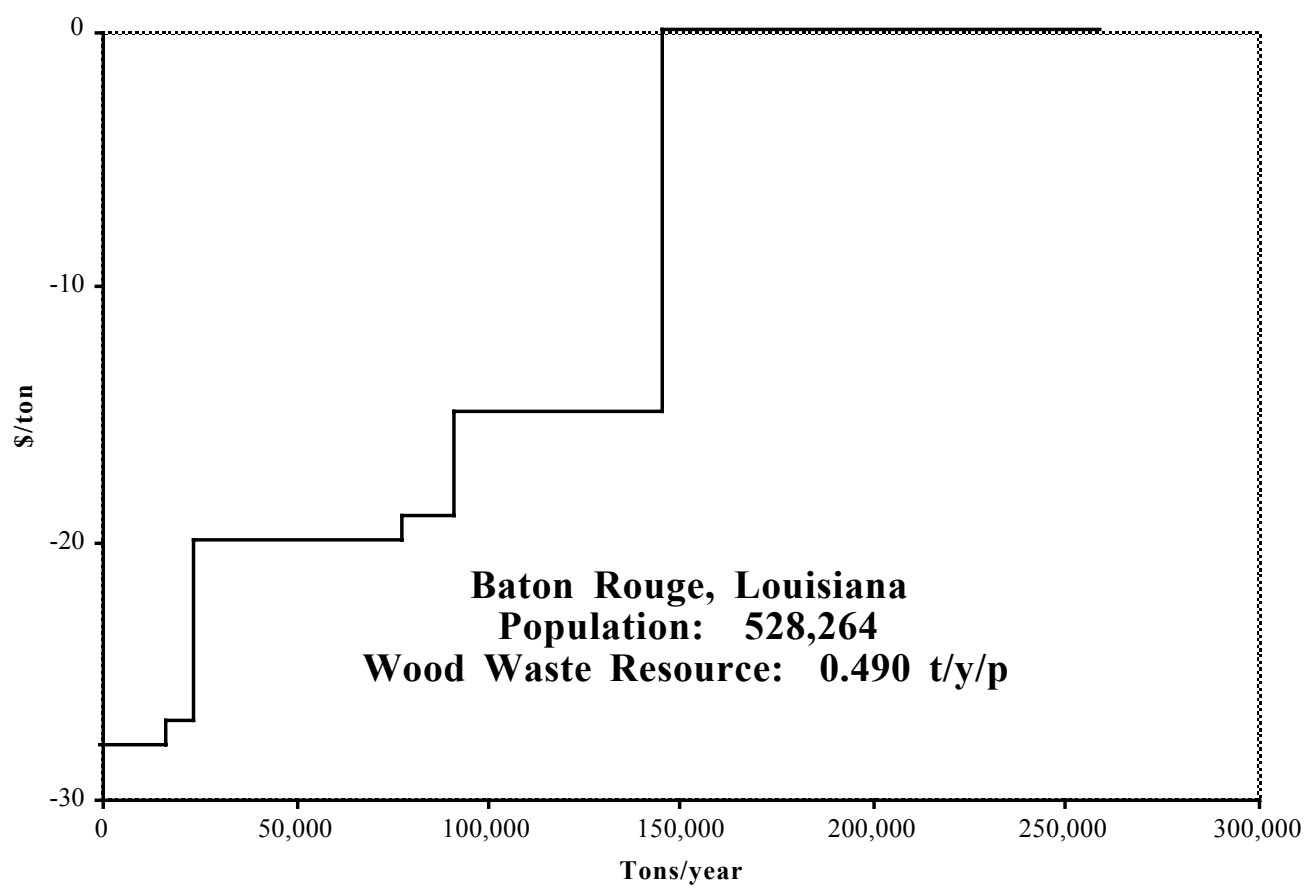

Figure 27-1. Supply Curve for Urban Wood Wastes in Baton Rouge, Louisiana

Table 27-4

Data and Assumptions Used in Supply Curve for Baton Rouge

Tons/year Cumulative $\frac{\text { \$/ton }}{16,300}$

$16,300 \frac{16,300}{-28}$

Assumptions/Comments

7,500 23,800 $\quad-27$ Landfilled with MSW and C/D - private landfill

24,200 48,000 -20 Landfilled with MSW and C/D - city landfill

$30,000 \quad 78,000 \quad-20 \quad$ Yard waste processed at city landfill

$13,000 \quad 91,000 \quad-19$ Wood processor - yard tipping fee

$55,000 \quad 146,000 \quad-15 \quad$ Wood processor - onsite incineration fee

$53,000 \quad 199,000 \quad 0 \quad$ Rural dumping or burning

$60,000 \quad 259,000 \quad 0 \quad$ Firewood, mulch, animal bedding - given away 
Shreveport is on the Red River in an oil and cotton rich area known as the "Ark-La-Tex." The metropolitan area consists of Shreveport, which is in Caddo Parish on the west bank of the Red River; and Bossier City, which is in Bossier Parish on the east bank of the river. Barksdale Air Force Base is on the southeastern perimeter of Bossier City.

Table 28-1 summarizes the data collected on urban wood resources in the Shreveport area. The estimated total urban wood waste resource, 0.325 tons/year/person, is about the same as the weighted average of 0.333 tons/year/person for the 30 metropolitan areas surveyed; the range for the 30 cities is from 0.156 to 0.829 tons/year/person. Other than the yard waste collected and composted, most of the wood waste in the area is simply dumped or burned. A biomass energy project might be able to obtain 50,000-70,000 tons/year of MSW and C/D wood at a relatively low cost, and produce 4-7 MW of electricity.

Table 28-1

Resource Estimate for Urban Wood Waste in Shreveport, Louisiana

\begin{tabular}{|c|c|c|c|c|c|}
\hline \multirow[b]{2}{*}{ Use or Disposal Method: } & \multicolumn{4}{|c|}{ Tons/Year } & \multirow[b]{2}{*}{$\begin{array}{c}\text { Price, } \\
\text { \$/ton }\end{array}$} \\
\hline & $\begin{array}{l}\text { MSW } \\
\text { Wood }\end{array}$ & $\begin{array}{c}\text { Industr. } \\
\text { Wood }\end{array}$ & $\begin{array}{c}\text { C/D } \\
\text { Wood }\end{array}$ & Total & \\
\hline Pulp chips & 1,000 & 2,000 & & 3,000 & 5 to 9 \\
\hline Mulch (ground cover) & 15,000 & & & 15,000 & 0 \\
\hline Animal bedding & & 1,100 & & 1,100 & 0 \\
\hline Firewood & 5,000 & 200 & & 5,200 & 0 \\
\hline Landfill, dumping, burning & 61,000 & 3,500 & 20,000 & 84,500 & 0 to -27 \\
\hline Total & 82,000 & 6,800 & 20,000 & 108,800 & \\
\hline Total, tons/year/person & 0.245 & 0.020 & 0.060 & 0.325 & \\
\hline
\end{tabular}

\section{Municipal Solid Waste (MSW) Collection and Disposal}

The Louisiana Department of Environmental Quality provided solid waste disposal statistics for the Shreveport landfill for the fiscal year that ended June 30, 1997, in tons/year:

\begin{tabular}{lr} 
Residential & 136,267 \\
Commercial & 158,256 \\
Trash & 7,851 \\
\cline { 2 - 2 } \multicolumn{1}{c}{ Total MSW } & 302,374 \\
C/D debris & 3,924
\end{tabular}

Shreveport and Bossier City haul residential trash to the Shreveport landfill, and haul yard waste to a 25 acre compost facility at the landfill that is operated by Scott Hyponex. Most of the compost is sold under the name "Shrevepost". Once a year there is a compost giveaway to residents. The Recycling Manager said they average about 10,000 tons/year of yard waste/compost, and that they probably get about half the material that could be collected if everyone would participate. Demand for compost exceeds the supply. The landfill tipping fee is $\$ 27 /$ ton. If people bring wood waste to the compost facility they are charged the same fee as if it were garbage; as a result, not much wood is hauled there. 
There are two C/D landfills in town, which charge tipping fees less than \$20/ton, and are also more conveniently located. Neither facility separates or grinds wood waste. I estimate that at least 40,000 tons/year of C/D debris are disposed of in these landfills. Based on the information above, my estimates of the amounts of wood waste entering landfills along with the solid waste in the Shreveport metropolitan area are approximately:

MSW wood: $5 \%$ of $302,000=15,000$ tons/year;

C/D wood: $20 \%$ of $45,000=9,000$ tons/year.

\section{MSW Wood (Primarily Tree and Yard Wastes)}

As discussed above, an estimated 15,000 tons/year of MSW wood waste is included in the solid waste going to landfills. Most of the yard waste generated in the area (about 10,000 tons/year) goes to the compost facility at the city landfill. None of the waste hauling companies I talked to in the Shreveport area (including BFI and Waste Management of Northwest Louisiana) separate or grind wood. BFI operates the city landfill.

Southwestern Electric Power Company (SWEPCO) employs contract tree service crews to keep its rights of way clear. The Louisiana Department of Environmental Quality requires the utility to report the amount of wood waste dumped by their contractors. The amount for the year ended June 30, 1996 was 8,238 tons. They commonly use "borrow pits" -pits dug to obtain dirt for freeway construction. I estimate that about 2,000 tons/year of firewood and about 2,000 tons/year of mulch are given away, in addition to the approximately 8,000 tons/year dumped by SWEPCO's tree service contractors.

The Shreveport Yellow Pages list 40 tree service companies. About 45 crews operate in the metropolitan area, generating about 45,000 tons/year of wood from tree trimming and removals, which is disposed of as follows: 1,000 tons/year of chips sold to pulp mills; 3,000 tons/year of firewood given away or sold; 3,000 tons/year of mulch given away; and 38,000 tons/year of wood burned or dumped in rural areas or "borrow pits".

Table 28-2 summarizes the estimated resources of MSW wood in the Shreveport area. The total estimate, 82,000 tons/year (of which about 61,000 tons/year are dumped or burned), is equivalent to 0.245 tons/year/person based on the metropolitan area population of 334,341. This is above the weighted average of 0.209 tons/year/person of MSW wood for the 30 metropolitan areas, which range from 0.134 to 0.538 tons/year/person.

\section{Table 28-2 \\ Resource Estimate for MSW Wood in Shreveport, Louisiana Tons/year}

\begin{tabular}{|c|c|c|c|c|c|}
\hline & $\begin{array}{l}\text { Pulp } \\
\text { Chips } \\
\end{array}$ & Mulch & $\begin{array}{l}\text { Fire- } \\
\text { wood }\end{array}$ & $\begin{array}{c}\text { Land- } \\
\text { fill * }\end{array}$ & Total \\
\hline Hauled with trash & & & & 15,000 & 15,000 \\
\hline Municipal yard waste recycl. & & 10,000 & & & 10,000 \\
\hline Utility tree trimming & & 2,000 & 2,000 & 8,000 & 12,000 \\
\hline Private tree service co's & 1,000 & 3,000 & 3,000 & 38,000 & 45,000 \\
\hline Total & 1,000 & 15,000 & 5,000 & 61,000 & 82,000 \\
\hline
\end{tabular}




\section{Industrial Wood Wastes}

The Shreveport Yellow Pages list four companies under Pallets and Skids; one company under Trusses-Construction; six companies under Lumber-Wholesale; five companies under Lumber; and 15 companies under Cabinet Makers, Furniture Designers \& Custom Builders, and Furniture Manufacturers (woodworking companies). The pallet companies are all small operations that either put their wood wastes in dumpsters or burn them (about 2,000 tons/year total). The truss company grinds up about 2,000 tons/year of wood waste and sells it to a company that makes a pressed board product. I have classified this material under "pulp chips" in the table.

The wholesale lumber companies in the Shreveport area generate at most about 1,000 tons/year of wood waste, nearly all of which is put in dumpsters. A very small amount (less than 100 tons/year) of sawdust is given away as grease cleanup material and animal bedding. The retail lumber companies generate about 200 tons/year of small wood scraps that go to firewood. Woodworking companies generate about 1,000 tons/year of animal bedding and 500 tons/year of waste wood that go to landfills or other dump sites.

Table 28-3 summarizes the estimated resources of industrial wood wastes in the Shreveport area. The total estimate of 6,800 tons/year is equivalent to about 0.020 tons/year/person based on the Shreveport metropolitan area population of 334,341. This is below the weighted average of 0.048 tons/year/person of industrial wood waste for the 30 metropolitan areas surveyed; the range is from 0.001 to 0.488 tons/year/person.

Table 28-3

Resource Estimate for Industrial Wood Wastes in Shreveport, Louisiana Tons/year

\begin{tabular}{|c|c|c|c|c|c|}
\hline & Landfill & $\begin{array}{l}\text { Pulp } \\
\text { Chips }\end{array}$ & $\begin{array}{l}\text { Animal } \\
\text { Beddin }\end{array}$ & $\begin{array}{l}\text { Fire- } \\
\text { wood }\end{array}$ & Total \\
\hline Pallet companies & 2,000 & & & & 2,000 \\
\hline Truss companies & & 2,000 & & & 2,000 \\
\hline Whlsl lumber co's & 1,000 & & 100 & & 1,100 \\
\hline Retail lumber co's & & & & 200 & 200 \\
\hline Woodworking co's & 500 & & 1,000 & & 1,500 \\
\hline Total & 3,500 & 2,000 & 1,100 & 200 & 6,800 \\
\hline
\end{tabular}

\section{Construction/Demolition Wood Wastes}

The Shreveport Yellow Pages list ten local companies under Demolition Contractors and ten companies under Land Clearing \& Leveling. All of the demolition contractors reported that they take their debris to C/D landfills. As discussed above under MSW Collection and Disposal, an estimated 9,000 tons/year of wood waste enters landfills with $\mathrm{C} / \mathrm{D}$ and land clearing debris in the Shreveport area. The land clearing companies I was able to talk to said they mostly burn the wood debris generated in land clearing work. Based on the information they provided, I estimate that about 11,000 tons/year of wood debris are burned by land clearing companies in the Shreveport metropolitan area. The estimated total of 20,000 tons/year is equivalent to 0.060 tons/year/person based on the Shreveport metropolitan area population of 334,341. This is below the weighted average of 0.076 tons/year/person of $\mathrm{C} / \mathrm{D}$ wood for the 30 metropolitan areas surveyed; the range is from 0.015 to 0.250 tons/year/person. 


\section{Supply Curve}

Figure 28-1 shows the supply curve for urban wood wastes in the Shreveport area. Table 28-4 shows the data and assumptions used to produce the supply curve.

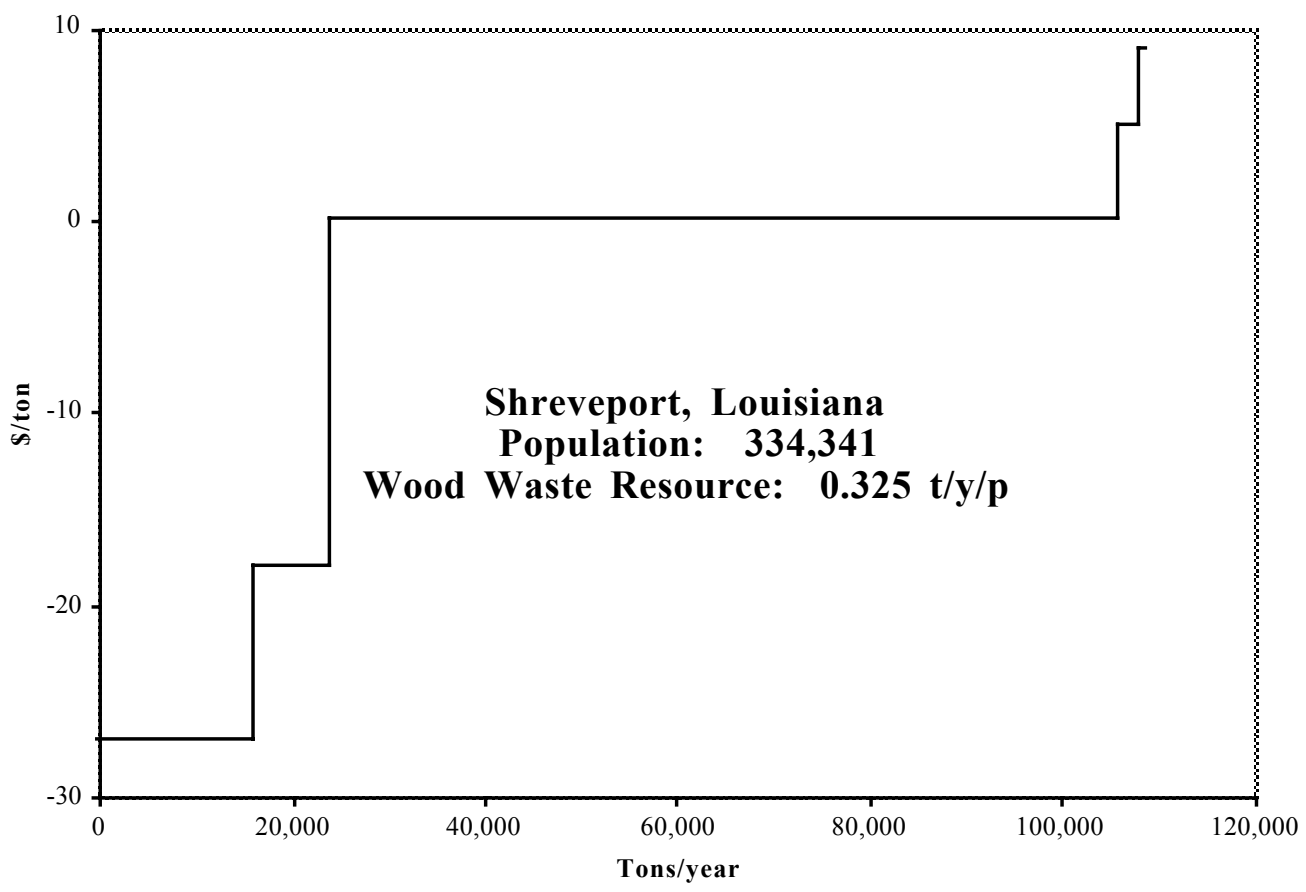

Figure 28-1. Supply Curve for Urban Wood Wastes in Shreveport, Louisiana

Table 28-4

Data and Assumptions Used in Supply Curve for Shreveport

Tons/year Cumulative $\frac{\text { \$/ton }}{16,000}$

$16,000 \frac{16,000}{-27}$

Assumptions/Comments

$8,000 \quad 24,000 \quad-18 \quad$ Landfilled with $\mathrm{C} / \mathrm{D}$ - private landfills

$60,500 \quad 84,500 \quad 0 \quad$ Rural dumping or burning

21,300 105,800 $0 \quad$ Firewood, mulch, animal bedding - given away

2,000 $\quad 107,800 \quad 5 \quad$ Furnish for pressed board - sold

$1,000 \quad 108,800 \quad 9 \quad$ Pulp chips - sold 
Beaumont and Port Arthur are located in southeastern Texas, a few miles from the Gulf of Mexico and the Louisiana border, and have a large concentration of oil refineries. Classified as a single metropolitan area, Beaumont and Port Arthur have separate solid waste programs, landfills, and telephone books. Adjacent to Port Arthur are Groves, Nederland, and Port Neches. All five cities lie in Jefferson County.

Table 29-1 summarizes the data collected on urban wood resources in the Beaumont-Port Arthur area. The estimated total urban wood waste resource, 0.340 tons/year/person, is about the same as the weighted average of 0.333 tons/year/person for the 30 metropolitan areas surveyed; the range for the 30 cities is from 0.156 to 0.829 tons/year/person. The cities have good yard waste collection programs that produce substantial amounts of mulch and compost. A biomass energy project might be able to obtain 60,000-90,000 tons/year of wood MSW and C/D wood at a relatively low cost, and produce 5-9 MW of electricity.

Table 29-1

Resource Estimate for Urban Wood Waste in Beaumont-Port Arthur, Texas

\begin{tabular}{|c|c|c|c|c|c|}
\hline \multirow[b]{2}{*}{ Use or Disposal Method: } & \multicolumn{4}{|c|}{ Tons/Year } & \multirow[b]{2}{*}{$\begin{array}{c}\text { Price } \\
\text { \$/ton }\end{array}$} \\
\hline & $\begin{array}{l}\text { MSW } \\
\text { Wood }\end{array}$ & $\begin{array}{c}\text { Industr. } \\
\text { Wood }\end{array}$ & $\begin{array}{c}\text { C/D } \\
\text { Wood }\end{array}$ & Total & \\
\hline Biomass fuel & & 3,000 & & 3,000 & 0 to 5 \\
\hline Animal bedding & & 200 & & 200 & 0 to 3 \\
\hline Firewood & 6,000 & 200 & & 6,200 & 0 \\
\hline Mulch* & 86,000 & & & 86,000 & 0 to -16 \\
\hline Landfill or incineration & 10,000 & 2,300 & 15,000 & 27,300 & 0 to -21 \\
\hline Total & 102,000 & 5,700 & 15,000 & 122,700 & \\
\hline Total, tons/year/person & 0.282 & 0.016 & 0.042 & 0.340 & \\
\hline
\end{tabular}

*“Mulch" includes compost, and probably some boiler fuel.

\section{Municipal Solid Waste (MSW) Collection and Disposal}

Beaumont and Port Arthur both provide residential trash pickup and yard waste collection and grinding services. The Beaumont landfill received about 121,000 tons/year of solid waste in 1997, of which about $20 \%$ was estimated to be C/D debris. The landfill's compost facility produces about 26,000 tons/year of compost, which is given away to city residents and sold to others. Tipping fees are $\$ 5.50 /$ cubic yard for non-compacted and $\$ 6.00 /$ cubic yard for compacted garbage. Local residents can bring yard wastes or tree wastes to the landfill composting facility for free, but commercial companies like tree service companies are charged $\$ 5.25 /$ cubic yard, which is equivalent to about $\$ 17 /$ ton.

The Port Arthur landfill received about 84,000 tons/year of solid waste in 1996, of which about 17,000 tons/year (20\%) was C/D debris. About 11,000 tons/year of yard waste are converted to mulch at the yard waste site at the landfill. The mulch is given away to citizens and used by the city in parks, etc. Residents of Port Arthur do not pay a tipping fee for garbage, but do pay a fee for $\mathrm{C} / \mathrm{D}$ debris. The tipping fee for non-residents and for $\mathrm{C} / \mathrm{D}$ debris is $\$ 6.50 /$ cubic yard. (For wood waste, this is equivalent to about \$21/ton.) 
Groves, Nederland, and Port Neches provide garbage and yard waste pickup, but deliver the garbage to the BFI Golden Triangle Landfill and the yard waste to Nelson Services' wood processing yard in Nederland. I estimate that the three cities generate a total of about 35,000 tons/year of solid waste, including about 20\% C/D debris. Nelson Services processes about 24,000 tons/year of yard waste, mostly from the three cities, for tipping fees of about $\$ 4.40 /$ cubic yard to the cities, and about $\$ 4.70 /$ cubic yard to private haulers (equivalent to about $\$ 14.50 /$ ton and $\$ 15.50 /$ ton, respectively). Nelson Services grinds the wood in a tub grinder and hauls it to its headquarters plant in Conroy, Texas (north of Houston), which produces a range of products including specialty mulches, compost, and boiler fuel. Nelson Services operates in five or more other cities in Texas and Louisiana.

In addition to about 61,000 tons/year of yard waste diverted from landfills and converted to mulch, compost, and other products, the following estimated amounts of wood waste enter landfills along with the solid waste in the Beaumont-Port Arthur area:

MSW wood: $5 \%$ of $192,000=10,000$ tons/year;

C/D wood: $20 \%$ of $48,000=10,000$ tons $/$ year.

\section{MSW Wood (Primarily Tree and Yard Wastes)}

None of the waste hauling companies (including BFI and Waste Management Golden Triangle) separate or grind wood. BFI takes pallets to the landfill; the BFI Recyclery in the area was shut down recently due to lack of business. Entergy employs about 11 contract tree service crews in this area to keep its utility lines and rights of way clear. Most of the 11,000 tons/year of wood generated by this tree trimming activity is given away as mulch and firewood. The Beaumont and Port Arthur Yellow Pages list 20 and five tree service companies, respectively. About 30 crews operate in the metropolitan area, generating about 30,000 tons/year of wood from tree trimming and removals. About 10,000 tons/year go to the Nelson Services yard and the city landfill wood grinding yards, and are included in the estimate given above for city yard waste programs. Of the remaining 20,000 tons/year, about 4,000 tons/year go to firewood and about 16,000 tons/year go to mulch.

Table 29-2 summarizes the estimated resources of MSW wood in the Beaumont-Port Arthur area. The total estimate, 102,000 tons/year (of which about 10,000 tons/year enter landfills), is equivalent to 0.282 tons/year/person based on the metropolitan area population of 361,226 . This is above the weighted average of 0.209 tons/year/person of MSW wood for the 30 metropolitan areas, which range from 0.134 to 0.538 tons/year/person.

Table 29-2

Resource Estimate for MSW Wood in Beaumont-Port Arthur, Texas Tons/year

\begin{tabular}{|c|c|c|c|c|}
\hline & Mulch* & $\begin{array}{l}\text { Fire- } \\
\text { wood }\end{array}$ & $\begin{array}{l}\text { Land- } \\
\text { fill }\end{array}$ & Total \\
\hline Hauled with trash & & & 10,000 & 10,000 \\
\hline Municipal yard waste recycl. & 51,000 & & & 51,000 \\
\hline Utility tree trimming & 9,000 & 2,000 & & 11,000 \\
\hline Private tree service co's & 26,000 & 4,000 & & 30,000 \\
\hline Total & 86,000 & 6,000 & 10,000 & 102,000 \\
\hline
\end{tabular}

*"Mulch" includes compost, and probably some boiler fuel. 


\section{Industrial Wood Wastes}

The Beaumont and Port Arthur Yellow Pages list two companies under Pallets and Skids; no companies under Trusses-Construction; five companies under Lumber-Wholesale; 18 companies under Lumber-Retail; and 33 companies under Cabinet Makers, Furniture Designers \& Custom Builders, and Furniture Manufacturers (woodworking companies). One of the pallet companies sells about 3,000 tons/year of sawdust to a paper mill as boiler fuel. The company also gives away a small amount of wood as firewood, and puts some broken pallets in a dumpster that BFI hauls to the landfill. The other pallet company has an incinerator, in which it disposes of an estimated 2,000 tons/year of wood waste.

The wholesale lumber companies in the area are all brokers who do no cutting. The retail lumber companies generate about 100 tons/year of small wood scraps that go to firewood. Woodworking companies generate 500 tons/year or less of wood scraps that are hauled to the landfill, used by family and friends, and/or given away as animal bedding.

Table 29-3 summarizes the estimated resources of industrial wood wastes in the BeaumontPort Arthur area. The total estimate of 5,700 tons/year is equivalent to about 0.016 tons/year/person based on the metropolitan area population of 361,226. This is below the weighted average of 0.048 tons/year/person of industrial wood waste for the 30 metropolitan areas surveyed; the range is from 0.001 to 0.488 tons/year/person.
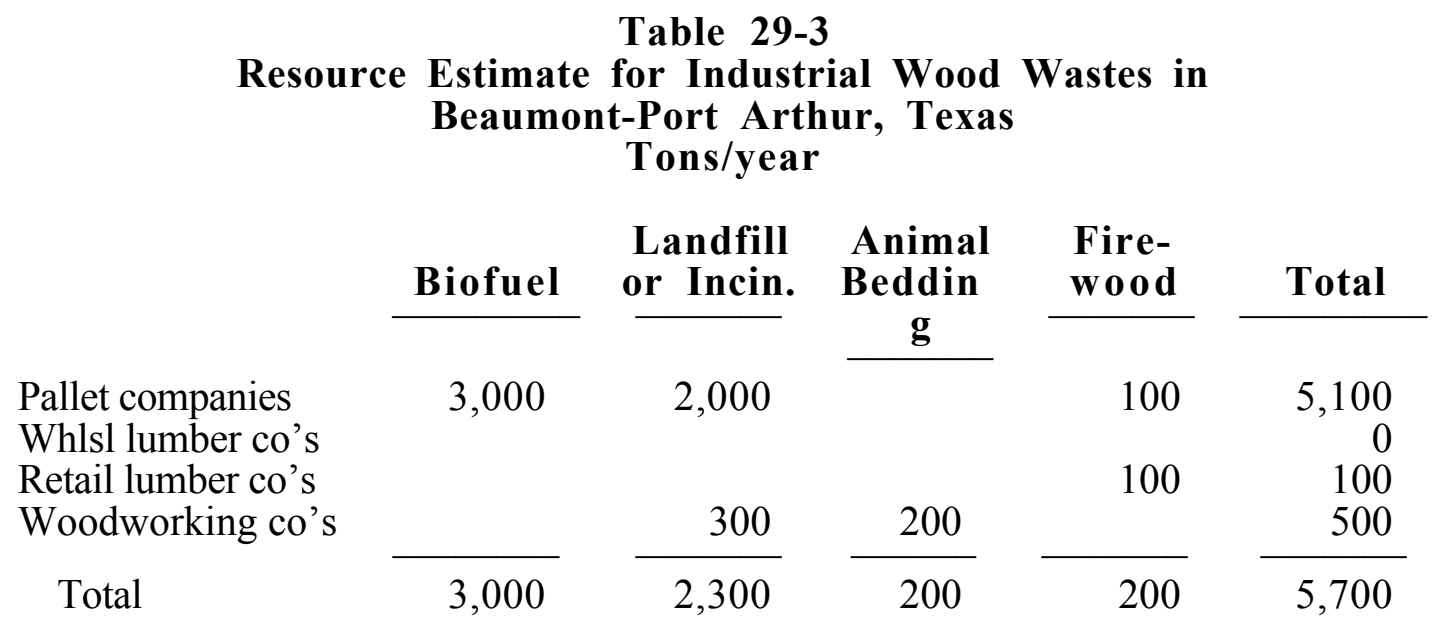

\section{Construction/Demolition Wood Wastes}

The Beaumont and Port Arthur Yellow Pages list two local companies under Demolition Contractors (other than iron and steel specialists) and eight companies under Land Clearing \& Leveling. I got through to only two of these companies; both reported that they take all of their debris to C/D landfills. The manager of the Nelson Services wood processing yard said that they receive very little land clearing wood debris, because there are not many trees on the undeveloped land in the area, and usually the land clearing companies just push and burn the small amounts that do exist.

As discussed above under MSW Collection and Disposal, an estimated 10,000 tons/year of wood waste enters landfills with $\mathrm{C} / \mathrm{D}$ and land clearing debris in the Beaumont-Port Arthur area. I estimate another 5,000 tons/year of land clearing wood are burned on rural job sites. The estimated total of 15,000 tons/year is equivalent to 0.042 tons/year/person based on the Beaumont-Port Arthur metropolitan area population of 361,226 . This is below the 
weighted average of 0.076 tons/year/person of $\mathrm{C} / \mathrm{D}$ wood for the 30 metropolitan areas surveyed; the range is from 0.015 to 0.250 tons/year/person.

\section{Supply Curve}

Figure 29-1 shows the supply curve for urban wood wastes in the Beaumont-Port Arthur area. Table 29-4 shows the data and assumptions used to produce the supply curve.

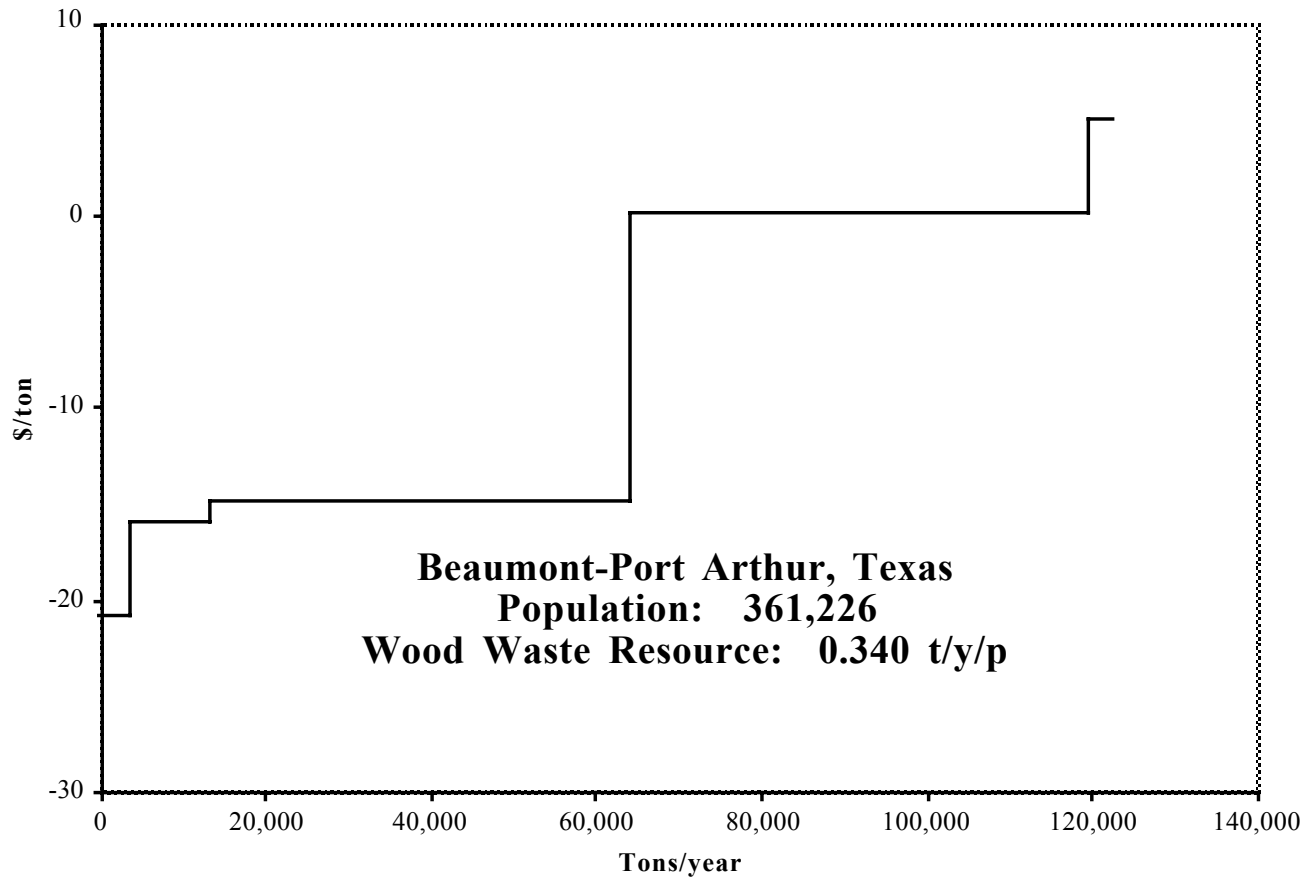

Figure 29-1. Supply Curve for Urban Wood Wastes in Beaumont-Port Arthur, Texas

Table 29-4

Data and Assumptions Used in Supply Curve for Beaumont-Port Arthur

Tons/year Cumulative $\frac{\text { \$/ton }}{3,400}$

$3,400 \frac{\text { Cum }}{3,400} \frac{\text { s/ton }}{-21}$

Assumptions/Comments

$10,000 \quad 13,400 \quad-16 \quad$ Wood processor - tipping fee to private haulers

$51,000 \quad 64,400 \quad-15 \quad$ Wood processor - tipping fee to city haulers

$16,600 \quad 81,000 \quad 0 \quad$ Landfilled with MSW and C/D - city landfills

$5,000 \quad 86,000 \quad 0 \quad$ Rural dumping or burning

33,700 $119,700 \quad 0 \quad$ Firewood, mulch, animal bedding - given away

$3,000 \quad 122,700 \quad 5 \quad$ Biofuel - sold 
Bryan-College Station is probably best known as the home of Texas A\&M University. Bryan is the county seat of Brazos County and is a commercial area near the center of the triangle formed by Dallas, Houston, and Austin. The local economy is based on diversified agriculture and industry, as well as the University. Bryan and College Station are contiguous, and share the same landfill, composting site, and telephone book.

Table 30-1 summarizes the data collected on urban wood resources in the Bryan-College Station area. The estimated total urban wood waste resource, 0.281 tons/year/person, is below the weighted average of 0.333 tons/year/person for the 30 metropolitan areas surveyed; the range for the 30 cities is from 0.156 to 0.829 tons/year/person. A biomass energy project might be able to obtain 15,000-30,000 tons/year of MSW and C/D wood at a relatively low cost, and produce 1-3 MW of electricity.

Table 30-1

Resource Estimate for Urban Wood Waste in Bryan-College Station, Texas

\begin{tabular}{|c|c|c|c|c|c|}
\hline \multirow[b]{2}{*}{ Use or Disposal Method: } & \multicolumn{4}{|c|}{ Tons/Year } & \multirow[b]{2}{*}{$\begin{array}{c}\text { Price } \\
\$ / \text { ton }\end{array}$} \\
\hline & $\begin{array}{l}\text { MSW } \\
\text { Wood }\end{array}$ & $\begin{array}{l}\text { Industr. } \\
\text { Wood }\end{array}$ & $\begin{array}{c}\text { C/D } \\
\text { Wood }\end{array}$ & Total & \\
\hline Animal bedding & & 200 & & 200 & 0 \\
\hline Rural burning & 7,000 & & 2,000 & 9,000 & 0 \\
\hline Firewood & 3,000 & 100 & & 3,100 & 0 \\
\hline Mulch & 9,000 & & & 9,000 & 0 to -12 \\
\hline Landfill & 8,000 & & 5,000 & 13,000 & -24 \\
\hline Total & 27,000 & 300 & 7,000 & 34,300 & \\
\hline Total, tons/year/person & 0.222 & 0.002 & 0.057 & 0.281 & \\
\hline
\end{tabular}

\section{Municipal Solid Waste (MSW) Collection and Disposal}

Bryan and College Station jointly own the Brazos Valley Waste Management Association (BVWMA) landfill, which receives about 180,000 tons/year of solid waste from a 13county area (all rural except for Bryan-College Station). The landfill manager estimates $\mathrm{C} / \mathrm{D}$ debris accounts for about $15 \%$ of this total. The tipping fee is $\$ 23.50 /$ ton. The landfill does no wood grinding; it refers all wood loads to the Bryan compost facility.

Bryan and College Station both pick up yard waste separately from residential garbage, and deliver it to the Bryan compost facility where a contractor grinds, screens, and blends it with sewage sludge, and produces compost that the city sells for $\$ 35.15 /$ ton. The tipping fee for wood wastes or yard wastes at the compost facility is $\$ 12 /$ ton. The total production of compost is currently about 6,000 tons/year. This includes tree and yard waste from Texas A\&M University, and some tree and wood wastes from private companies. Based on the information above, my estimates of the amounts of wood waste entering landfills along with the solid waste in the Bryan-College Station area are approximately:

MSW wood: $5 \%$ of $153,000=8,000$ tons/year;

C/D wood: $20 \%$ of $27,000=5,000$ tons/year. 


\section{MSW Wood (Primarily Tree and Yard Wastes)}

As discussed above, an estimated 8,000 tons/year of MSW wood waste is included in the solid waste going to landfills. Most of the yard waste in the area (about 6,000 tons/year) goes to the Bryan compost facility. I estimate that 5,000 tons/year of this comes from city yard waste collection, and 1,000 tons/year comes from private tree service companies. None of the waste hauling companies in the Bryan-College Station area (three small local companies) separate or grind wood.

Entergy employs about four contract tree service crews to keep its utility lines and rights of way clear. Most of the 4,000 tons/year of wood generated by this tree trimming activity is given away as firewood and mulch. The Bryan-College Station Yellow Pages list nine tree service companies. About ten crews operate in the metropolitan area, generating about 10,000 tons/year of wood from tree trimming and removals. About 2,000 tons/year go to firewood, 7,000 tons/year are burned in rural areas, and 1,000 tons/year are hauled to the Bryan compost facility and included in the 6,000 tons/year of compost produced there.

Table 30-2 summarizes the estimated resources of MSW wood in the Bryan-College Station area. The total estimate, 27,000 tons/year (of which about 8,000 tons/year enter the landfill), is equivalent to 0.222 tons/year/person based on the metropolitan area population of 121,862 . This is above the weighted average of 0.209 tons/year/person of MSW wood for the 30 metropolitan areas, which range from 0.134 to 0.538 tons/year/person.

\section{Table 30-2 \\ Resource Estimate for MSW Wood in Bryan-College Station, Texas Tons/year}

\begin{tabular}{|c|c|c|c|c|c|}
\hline & $\begin{array}{c}\text { Rural } \\
\text { Burning }\end{array}$ & Mulch & $\begin{array}{l}\text { Fire- } \\
\text { wood }\end{array}$ & $\begin{array}{l}\text { Land- } \\
\text { fill }\end{array}$ & Total \\
\hline Hauled with trash & & & & 8,000 & 8,000 \\
\hline Municipal yard waste recycl. & & 5,000 & & & 5,000 \\
\hline Utility tree trimming & & 3,000 & 1,000 & & 4,000 \\
\hline Private tree service co's & 7,000 & 1,000 & 2,000 & & 10,000 \\
\hline Total & 7,000 & 9,000 & 3,000 & 8,000 & 27,000 \\
\hline
\end{tabular}

\section{Industrial Wood Wastes}

The Bryan-College Station Yellow Pages list no companies under Pallets and Skids; no companies under Trusses-Construction; no companies under Lumber-Wholesale; five companies under Lumber-Retail; and 15 companies under Cabinet Makers, Furniture Designers \& Custom Builders, and Furniture Manufacturers (woodworking companies). The retail lumber companies in the Bryan-College Station area generate about 100 tons/year of small wood scraps that go to firewood. Woodworking companies generate 200 tons/year or less of wood scraps that are burned, used by family and friends, and/or given away as animal bedding.

Thus, the estimated resources of industrial wood wastes in the Bryan-College Station metropolitan area include about 100 tons/year of firewood and 200 tons/year of animal bedding. The total estimate of 300 tons/year is equivalent to about 0.002 tons/year/person based on the Bryan-College Station metropolitan area population of 121,862. This is one of the lowest per capita industrial wood waste estimates for the 30 metropolitan areas surveyed, which range from 0.001 to 0.488 and average 0.048 tons/year/person. 


\section{Construction/Demolition Wood Wastes}

The Bryan-College Station Yellow Pages list three companies under Demolition Contractors and three companies under Land Clearing \& Leveling. All of these companies reported that they take their debris to the landfill unless the site is rural, in which case tree debris is pushed and burned on site. As discussed above under MSW Collection and Disposal, an estimated 5,000 tons/year of wood waste enter landfills with $\mathrm{C} / \mathrm{D}$ and land clearing debris in the Bryan-College Station area. I estimate another 2,000 tons/year of land clearing wood are burned on rural job sites. The estimated total of 7,000 tons/year is equivalent to 0.057 tons/year/person based on the metropolitan area population of 121,862 . This is below the weighted average of 0.076 tons/year/person of $C / D$ wood for the 30 metropolitan areas surveyed; the range is from 0.015 to 0.250 tons/year/person.

\section{Supply Curve}

Figure 30-1 shows the supply curve for urban wood wastes in the Bryan-College Station area. Table 30-3 shows the data and assumptions used to produce the supply curve.

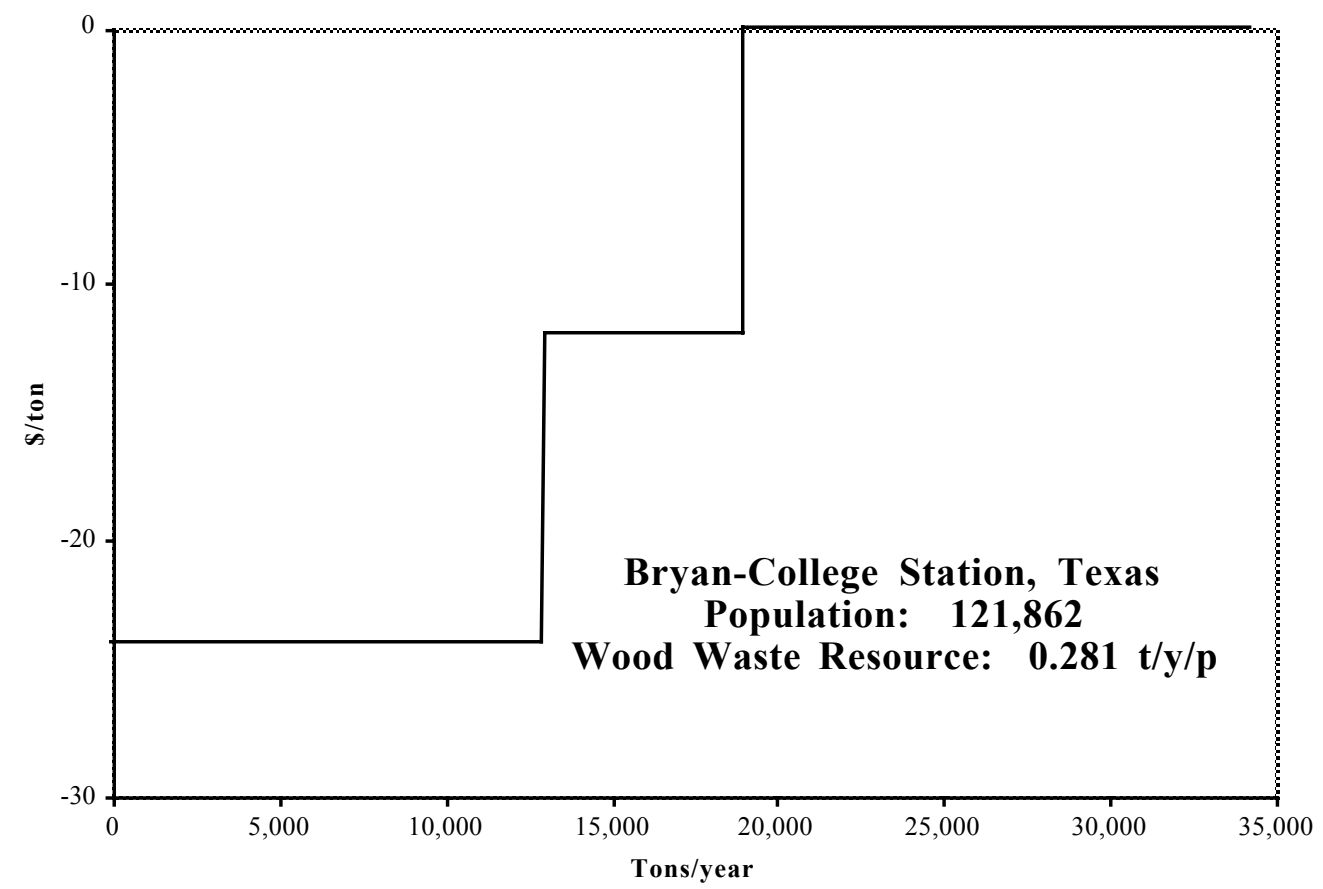

Figure 30-1. Supply Curve for Urban Wood Wastes in Bryan-College Station, Texas

Table 30-3

Data and Assumptions Used in Supply Curve for Bryan-College Station

Tons/year Cumulative $\$$ /ton

\begin{tabular}{|c|c|c|c|}
\hline 13,000 & 13,000 & -24 & Landfilled with MSW and C/D - city landfill \\
\hline & 19,000 & -12 & ipping fee \\
\hline & 34,300 & 0 & imal bedding \\
\hline
\end{tabular}




\section{APPENDIX A -- METROPOLITAN AREAS}

Table A1 lists the 281 metropolitan areas in the United States in order of population.

Table A2 lists them by state. 
Table A1 - 281 Metropolitan Areas in Order of Population

\begin{tabular}{|c|c|c|c|}
\hline & & 1990 & Pop. \\
\hline Metropolitan Area & State & Population & Rank \\
\hline New York-Northern New Jersey-Long Island & NY & $17,953,372$ & 1 \\
\hline Los Angeles-Anaheim-Riverside & $\mathrm{CA}$ & $14,531,529$ & 2 \\
\hline Chicago-Gary-Lake County & IL & $8,065,633$ & 3 \\
\hline San Francisco-Oakland-San Jose & CA & $6,253,311$ & 4 \\
\hline Philadelphia-Wilmington-Trenton & PA & $5,899,345$ & 5 \\
\hline Detroit-Ann Arbor & MI & $4,665,236$ & 6 \\
\hline Washington & $\mathrm{DC}$ & $3,923,574$ & 7 \\
\hline Dallas-Ft. Worth & TX & $3,885,415$ & 8 \\
\hline Boston-Lawrence-Salem-Lowell-Brockton & MA & $3,783,817$ & 9 \\
\hline Houston-Galveston-Brazoria & TX & $3,711,043$ & 10 \\
\hline Miami-Fort Lauderdale & FL & $3,192,582$ & 11 \\
\hline Atlanta & GA & $2,833,511$ & 12 \\
\hline Cleveland-Akron-Lorain & $\mathrm{OH}$ & $2,759,823$ & 13 \\
\hline Seattle-Tacoma & WA & $2,559,164$ & 14 \\
\hline San Diego & CA & $2,498,016$ & 15 \\
\hline Minneapolis-St. Paul & $\mathrm{MN}$ & $2,464,124$ & 16 \\
\hline St. Louis & $\mathrm{MO}$ & $2,444,099$ & 17 \\
\hline Baltimore & MD & $2,382,172$ & 18 \\
\hline Pittsburgh-Beaver Valley & PA & $2,242,798$ & 19 \\
\hline Phoenix & $\mathrm{AZ}$ & $2,122,101$ & 20 \\
\hline Tampa-St. Petersburg-Clearwater & FL & $2,067,959$ & 21 \\
\hline Denver-Boulder & $\mathrm{CO}$ & $1,848,319$ & 22 \\
\hline Cincinnati-Hamilton & $\mathrm{OH}$ & $1,744,124$ & 23 \\
\hline Milwaukee-Racine & WI & $1,607,183$ & 24 \\
\hline Kansas City & $\mathrm{MO}$ & $1,566,280$ & 25 \\
\hline Sacramento & CA & $1,481,102$ & 26 \\
\hline Portland-Vancouver & OR & $1,477,895$ & 27 \\
\hline Norfolk-Virginia Beach-Newport News & VA & $1,396,107$ & 28 \\
\hline Columbus & $\mathrm{OH}$ & $1,377,419$ & 29 \\
\hline San Antonio & TX & $1,302,099$ & 30 \\
\hline Indianapolis & IN & $1,249,822$ & 31 \\
\hline New Orleans & LA & $1,238,816$ & 32 \\
\hline Buffalo-Niagara Falls & NY & $1,189,288$ & 33 \\
\hline Charlotte-Gastonia-Rock Hill & $\mathrm{NC}$ & $1,162,093$ & 34 \\
\hline Hartford-New Britain-Middletown-Bristol & $\mathrm{CT}$ & $1,123,678$ & 35 \\
\hline Orlando & FL & $1,072,748$ & 36 \\
\hline Salt Lake City-Ogden & UT & $1,072,227$ & 37 \\
\hline Rochester & NY & $1,002,410$ & 38 \\
\hline Nashville & $\mathrm{TN}$ & 985,026 & 39 \\
\hline Memphis & $\mathrm{TN}$ & 981,747 & 40 \\
\hline Oklahoma City & OK & 958,839 & 41 \\
\hline Louisville & KY & 952,662 & 42 \\
\hline Dayton-Springfield & $\mathrm{OH}$ & 951,270 & 43 \\
\hline Greensboro-Winston-Salem-High Point & $\mathrm{NC}$ & 942,091 & 44 \\
\hline Providence-Pawtucket-Woonsocket & RI & 916,270 & 45 \\
\hline Birmingham & $\mathrm{AL}$ & 907,810 & 46 \\
\hline Jacksonville & FL & 906,727 & 47 \\
\hline
\end{tabular}

Table A1 - Page 1 
Table A1 - 281 Metropolitan Areas in Order of Population

\begin{tabular}{|c|c|c|c|}
\hline & & 1990 & Pop. \\
\hline Metropolitan Area & State & Population & Rank \\
\hline Albany-Schenechtady-Troy & NY & 874,304 & 48 \\
\hline Richmond-Petersburg & VA & 865,640 & 49 \\
\hline West Palm Beach-Boca Raton-Delray Beach & FL & 863,518 & 50 \\
\hline Honolulu & $\mathrm{HI}$ & 836,231 & 51 \\
\hline New Haven-Waterbury-Meriden & $\mathrm{CT}$ & 804,219 & 52 \\
\hline Austin & $\mathrm{TX}$ & 781,572 & 53 \\
\hline Las Vegas & NV & 741,459 & 691 \\
\hline Raleigh-Durham & $\mathrm{NC}$ & 735,480 & 55 \\
\hline Scranton--Wilkes-Barre & $\mathrm{PA}$ & 734,175 & 56 \\
\hline Worcester-Fitchburg-Leominster & MA & 709,705 & 57 \\
\hline Tulsa & $\mathrm{OK}$ & 708,954 & 58 \\
\hline Grand Rapids & MI & 688,399 & 59 \\
\hline Allentown-Bethlehem & PA & 686,688 & 60 \\
\hline Fresno & $\mathrm{CA}$ & 667,490 & 61 \\
\hline Tucson & $\mathrm{AZ}$ & 666,880 & 62 \\
\hline Syracuse & NY & 659,864 & 63 \\
\hline Greenville-Spartanburg & $\mathrm{SC}$ & 640,861 & 64 \\
\hline Omaha & $\mathrm{NE}$ & 618,262 & 65 \\
\hline Toledo & $\mathrm{OH}$ & 614,128 & 66 \\
\hline Knoxville & $\mathrm{TN}$ & 604,816 & 67 \\
\hline Springfield & MA & 602,878 & 68 \\
\hline El Paso & TX & 591,610 & 69 \\
\hline Harrisburg-Lebanon-Carlisle & PA & 587,986 & 70 \\
\hline Bakersfield & $\mathrm{CA}$ & 543,477 & 71 \\
\hline Baton Rouge & LA & 528,264 & 72 \\
\hline Little Rock-North Little Rock & AR & 513,117 & 73 \\
\hline Charleston & $\mathrm{SC}$ & 506,875 & 74 \\
\hline New Bedford-Fall River-Attleboro & MA & 506,325 & 75 \\
\hline Youngstown-Warren & $\mathrm{OH}$ & 492,619 & 76 \\
\hline Wichita & KS & 485,270 & 77 \\
\hline Stockton & $\mathrm{CA}$ & 480,628 & 78 \\
\hline Albuquerque & NM & 480,577 & 79 \\
\hline Mobile & $\mathrm{AL}$ & 476,923 & 80 \\
\hline Columbia & $\mathrm{SC}$ & 453,331 & 81 \\
\hline Johnson City-Kingsport-Bristol & TN & 436,047 & 82 \\
\hline Chattanooga & $\mathrm{TN}$ & 433,210 & 83 \\
\hline Lansing-East Lansing & MI & 432,674 & 84 \\
\hline Flint & MI & 430,459 & 85 \\
\hline Lancaster & PA & 422,822 & 86 \\
\hline York & PA & 417,848 & 87 \\
\hline Lakeland-Winter Haven & FL & 405,382 & 88 \\
\hline Saginaw-Bay City-Midland & MI & 399,320 & 89 \\
\hline Melbourne-Titusville-Palm Bay & FL & 398,978 & 90 \\
\hline Colorado Springs & $\mathrm{CO}$ & 397,014 & 91 \\
\hline Augusta & GA & 396,809 & 92 \\
\hline Jackson & MS & 395,396 & 93 \\
\hline Canton & $\mathrm{OH}$ & 394,106 & 94 \\
\hline
\end{tabular}

Table A1 - Page 2 
Table A1 - 281 Metropolitan Areas in Order of Population

\begin{tabular}{|c|c|c|c|}
\hline & & 1990 & Pop. \\
\hline Metropolitan Area & State & Population & Rank \\
\hline Des Moines & IA & 392,928 & 95 \\
\hline McAllen-Edinburg-Mission & TX & 383,545 & 96 \\
\hline Daytona Beach & FL & 370,712 & 97 \\
\hline Modesto & $\mathrm{CA}$ & 370,522 & 98 \\
\hline Santa Barbara-Santa Maria-Lompoc & $\mathrm{CA}$ & 369,608 & 99 \\
\hline Madison & WI & 367,085 & 100 \\
\hline Fort Wayne & IN & 363,811 & 101 \\
\hline Spokane & WA & 361,364 & 102 \\
\hline Beaumont-Port Arthur & TX & 361,226 & 103 \\
\hline Salinas-Seaside-Monterey & $\mathrm{CA}$ & 355,660 & 104 \\
\hline Davenport-Rock Island-Moline & IA & 350,861 & 105 \\
\hline Portsmouth-Dover-Rochester & $\mathrm{NH}$ & 350,078 & 106 \\
\hline Corpus Christi & TX & 349,894 & 107 \\
\hline Lexington-Fayette & KY & 348,428 & 108 \\
\hline Pensacola & FL & 344,406 & 109 \\
\hline Peoria & IL & 339,172 & 110 \\
\hline Reading & $\mathrm{PA}$ & 336,523 & 111 \\
\hline Manchester-Nashua & $\mathrm{NH}$ & 336,073 & 112 \\
\hline Fort Myers-Cape Coral & FL & 335,113 & 113 \\
\hline Shreveport & LA & 334,341 & 114 \\
\hline Atlantic City & NJ & 319,416 & 115 \\
\hline Utica-Rome & NY & 316,633 & 116 \\
\hline Appleton-Oshkosh-Neenah & WI & 315,121 & 117 \\
\hline Huntington-Ashland & WV & 312,529 & 118 \\
\hline Visalia-Tulare-Porterville & $\mathrm{CA}$ & 311,921 & 119 \\
\hline Montgomery & $\mathrm{AL}$ & 292,517 & 120 \\
\hline Rockford & IL & 283,719 & 121 \\
\hline Eugene-Springfield & OR & 282,912 & 122 \\
\hline Macon-Warner Robins & GA & 281,103 & 123 \\
\hline Evansville & $\mathrm{IN}$ & 278,990 & 124 \\
\hline Salem & OR & 278,024 & 125 \\
\hline Sarasota & FL & 277,776 & 126 \\
\hline Erie & $\mathrm{PA}$ & 275,572 & 127 \\
\hline Fayetteville & $\mathrm{NC}$ & 274,566 & 128 \\
\hline Binghamton & NY & 264,497 & 129 \\
\hline Provo-Orem & UT & 263,590 & 130 \\
\hline Brownsville-Harlingen & TX & 260,120 & 131 \\
\hline Poughkeepsie & NY & 259,462 & 132 \\
\hline Killeen-Temple & TX & 255,301 & 133 \\
\hline New London-Norwich & $\mathrm{CT}$ & 254,957 & 134 \\
\hline Reno & NV & 254,667 & 135 \\
\hline Fort Pierce & FL & 251,071 & 136 \\
\hline Charleston & WV & 250,454 & 137 \\
\hline South Bend-Mishawaka & IN & 247,052 & 138 \\
\hline Portland & $\mathrm{ME}$ & 243,135 & 139 \\
\hline Columbus & GA & 243,072 & 140 \\
\hline Savannah & GA & 242,622 & 141 \\
\hline
\end{tabular}

Table A1 - Page 3 
Table A1 - 281 Metropolitan Areas in Order of Population

\begin{tabular}{|c|c|c|c|}
\hline & & 1990 & Pop. \\
\hline Metropolitan Area & State & Population & Rank \\
\hline Johnstown & PA & 241,247 & 142 \\
\hline Springfield & $\mathrm{MO}$ & 240,593 & 143 \\
\hline Duluth & $\mathrm{MN}$ & 239,971 & 144 \\
\hline Huntsville & $\mathrm{AL}$ & 238,912 & 145 \\
\hline Tallahassee & FL & 233,598 & 146 \\
\hline Anchorage & AK & 226,338 & 147 \\
\hline Roanoke & VA & 224,477 & 148 \\
\hline Kalamazoo & MI & 223,411 & 149 \\
\hline Lubbock & TX & 222,636 & 150 \\
\hline Hickory & $\mathrm{NC}$ & 221,700 & 151 \\
\hline Lincoln & $\mathrm{NE}$ & 213,641 & 152 \\
\hline Bradenton & FL & 211,707 & 153 \\
\hline Lafayette & LA & 208,740 & 154 \\
\hline Boise & ID & 205,775 & 155 \\
\hline Gainesville & FL & 204,111 & 156 \\
\hline Biloxi-Gulfport & MS & 197,125 & 157 \\
\hline Ocala & FL & 194,833 & 158 \\
\hline Green Bay & WI & 194,594 & 159 \\
\hline St. Cloud & $\mathrm{MN}$ & 190,921 & 160 \\
\hline Bremerton & WA & 189,731 & 161 \\
\hline Springfield & IL & 189,550 & 162 \\
\hline Waco & TX & 189,123 & 163 \\
\hline Yakima & WA & 188,823 & 164 \\
\hline Amarillo & TX & 187,547 & 165 \\
\hline Fort Collins-Loveland & $\mathrm{CO}$ & 186,136 & 166 \\
\hline Houma-Thibodaux & LA & 182,842 & 167 \\
\hline Chico & $\mathrm{CA}$ & 182,120 & 168 \\
\hline Merced & $\mathrm{CA}$ & 178,403 & 169 \\
\hline Fort Smith & AR & 175,911 & 170 \\
\hline Asheville & $\mathrm{NC}$ & 174,821 & 171 \\
\hline Champaign-Urbana-Rantoul & IL & 173,025 & 172 \\
\hline Clarksville-Hopkinsville & $\mathrm{TN}$ & 169,439 & 173 \\
\hline Cedar Rapids & IA & 168,767 & 174 \\
\hline Lake Charles & LA & 168,134 & 175 \\
\hline Longview-Marshall & $\mathrm{TX}$ & 162,431 & 176 \\
\hline Benton Harbor & MI & 161,378 & 177 \\
\hline Olympia & WA & 161,238 & 178 \\
\hline Topeka & KS & 160,976 & 179 \\
\hline Wheeling & WV & 159,301 & 180 \\
\hline Muskegon & MI & 158,983 & 181 \\
\hline Athens & GA & 156,267 & 182 \\
\hline Elkhart-Goshen & $\mathrm{IN}$ & 156,198 & 183 \\
\hline Lima & $\mathrm{OH}$ & 154,340 & 184 \\
\hline Fargo-Moorhead & ND & 153,296 & 185 \\
\hline Naples & FL & 152,099 & 186 \\
\hline Tyler & TX & 151,309 & 187 \\
\hline Tuscaloosa & $\mathrm{AL}$ & 150,522 & 188 \\
\hline
\end{tabular}

Table A1 - Page 4 
Table A1 - 281 Metropolitan Areas in Order of Population

\begin{tabular}{|c|c|c|c|}
\hline & & 1990 & Pop. \\
\hline Metropolitan Area & State & Population & Rank \\
\hline Richland-Kennewick-Pasco & WA & 150,033 & 189 \\
\hline Jacksonville & $\mathrm{NC}$ & 149,838 & 190 \\
\hline Jackson & MI & 149,756 & 191 \\
\hline Parkersburg-Marietta & WV & 149,169 & 192 \\
\hline Redding & $\mathrm{CA}$ & 147,036 & 193 \\
\hline Waterloo-Cedar Falls & IA & 146,611 & 194 \\
\hline Bangor & $\mathrm{ME}$ & 146,601 & 195 \\
\hline Medford & OR & 146,389 & 196 \\
\hline Anderson & $\mathrm{SC}$ & 145,196 & 197 \\
\hline Fort Walton Beach & FL & 143,776 & 198 \\
\hline Steubenville-Weirton & $\mathrm{OH}$ & 142,523 & 199 \\
\hline Lynchburg & VA & 142,199 & 200 \\
\hline Monroe & LA & 142,191 & 201 \\
\hline Jamestown-Dunkirk & NY & 141,895 & 202 \\
\hline Janesville-Beloit & WI & 139,510 & 203 \\
\hline Pittsfield & MA & 139,352 & 204 \\
\hline Eau Claire & WI & 137,543 & 205 \\
\hline Burlington & VT & 137,079 & 206 \\
\hline Battle Creek & MI & 135,982 & 207 \\
\hline Las Cruces & NM & 135,510 & 208 \\
\hline Joplin & $\mathrm{MO}$ & 134,910 & 209 \\
\hline Laredo & TX & 133,239 & 210 \\
\hline Greeley & $\mathrm{CO}$ & 131,821 & 211 \\
\hline Alexandria & LA & 131,556 & 212 \\
\hline Decatur & $\mathrm{AL}$ & 131,556 & 212 \\
\hline Florence & $\mathrm{AL}$ & 131,327 & 214 \\
\hline Charlottesville & VA & 131,107 & 215 \\
\hline Dothan & $\mathrm{AL}$ & 130,964 & 216 \\
\hline Terre Haute & $\mathrm{IN}$ & 130,812 & 217 \\
\hline Anderson & $\mathrm{IN}$ & 130,669 & 218 \\
\hline Lafayette-West Lafayette & $\mathrm{IN}$ & 130,598 & 219 \\
\hline Altoona & $\mathrm{PA}$ & 130,542 & 220 \\
\hline Bloomington-Normal & IL & 129,180 & 221 \\
\hline Bellingham & WA & 127,780 & 222 \\
\hline Panama City & FL & 126,994 & 223 \\
\hline Mansfield & $\mathrm{OH}$ & 126,137 & 224 \\
\hline Sioux Falls & SD & 123,809 & 225 \\
\hline State College & $\mathrm{PA}$ & 123,786 & 226 \\
\hline Pueblo & $\mathrm{CO}$ & 123,051 & 227 \\
\hline Yuba City & $\mathrm{CA}$ & 122,643 & 228 \\
\hline Wichita Falls & TX & 122,378 & 229 \\
\hline Bryan-College Station & $\mathrm{TX}$ & 121,862 & 230 \\
\hline Hagerstown & MD & 121,393 & 231 \\
\hline Sharon & $\mathrm{PA}$ & 121,003 & 232 \\
\hline Wilmington & $\mathrm{NC}$ & 120,284 & 233 \\
\hline Texarkana & TX & 120,132 & 234 \\
\hline Muncie & $\mathrm{IN}$ & 119,659 & 235 \\
\hline
\end{tabular}

Table A1 - Page 5 
Table A1 - 281 Metropolitan Areas in Order of Population

\begin{tabular}{|c|c|c|c|}
\hline & & 1990 & Pop. \\
\hline Metropolitan Area & State & Population & Rank \\
\hline Abilene & TX & 119,655 & 236 \\
\hline Odessa & TX & 118,934 & 237 \\
\hline Williamsport & PA & 118,710 & 238 \\
\hline Glens Falls & NY & 118,539 & 239 \\
\hline Decatur & IL & 117,206 & 240 \\
\hline Santa Fe & NM & 117,043 & 241 \\
\hline Anniston & $\mathrm{AL}$ & 116,034 & 242 \\
\hline Wausau & WI & 115,400 & 243 \\
\hline Pascagoula & MS & 115,243 & 244 \\
\hline Sioux City & IA & 115,018 & 245 \\
\hline Florence & $\mathrm{SC}$ & 114,344 & 246 \\
\hline Billings & MT & 113,419 & 247 \\
\hline Fayetteville-Springdale & $\mathrm{AR}$ & 113,409 & 248 \\
\hline Albany & GA & 112,561 & 249 \\
\hline Columbia & $\mathrm{MO}$ & 112,379 & 250 \\
\hline Lawton & OK & 111,486 & 251 \\
\hline Bloomington & IN & 108,978 & 252 \\
\hline Danville & VA & 108,711 & 253 \\
\hline Burlington & $\mathrm{NC}$ & 108,213 & 254 \\
\hline Midland & TX & 106,611 & 255 \\
\hline Rochester & $\mathrm{MN}$ & 106,470 & 256 \\
\hline Lewiston-Auburn & $\mathrm{ME}$ & 105,259 & 257 \\
\hline Sheboygan & WI & 103,877 & 258 \\
\hline Cumberland & MD & 101,643 & 259 \\
\hline Gadsden & $\mathrm{AL}$ & 99,840 & 260 \\
\hline San Angelo & TX & 98,458 & 261 \\
\hline La Crosse & WI & 97,904 & 262 \\
\hline Kokomo & IN & 96,946 & 263 \\
\hline Kankakee & IL & 96,255 & 264 \\
\hline Iowa City & IA & 96,119 & 265 \\
\hline Elmira & NY & 95,195 & 266 \\
\hline Sherman-Denison & TX & 95,021 & 267 \\
\hline Owensboro & KY & 87,189 & 268 \\
\hline Dubuque & IA & 86,403 & 269 \\
\hline Pine Bluff & $\mathrm{AR}$ & 85,487 & 270 \\
\hline Bismarck & ND & 83,831 & 271 \\
\hline St. Joseph & MO & 83,083 & 272 \\
\hline Lawrence & $\mathrm{KS}$ & 81,798 & 273 \\
\hline Rapid City & SD & 81,343 & 274 \\
\hline Jackson & $\mathrm{TN}$ & 77,982 & 275 \\
\hline Great Falls & MT & 77,691 & 276 \\
\hline Victoria & TX & 74,361 & 277 \\
\hline Cheyenne & WY & 73,142 & 278 \\
\hline Grand Forks & ND & 70,683 & 279 \\
\hline Casper & WY & 61,226 & 280 \\
\hline Enid & $\mathrm{OK}$ & 56,735 & 281 \\
\hline
\end{tabular}

Table A1 - Page 6 
Table A2 - 281 Metropolitan Areas by State

\begin{tabular}{|c|c|c|c|c|}
\hline & & 1990 & Pop. & State Metro \\
\hline Metropolitan Area & State & Population & Rank & Population \\
\hline Anchorage & $\mathrm{AK}$ & 226,338 & 147 & 226,338 \\
\hline Birmingham & $\mathrm{AL}$ & 907,810 & 46 & \\
\hline Mobile & $\mathrm{AL}$ & 476,923 & 80 & \\
\hline Montgomery & $\mathrm{AL}$ & 292,517 & 120 & \\
\hline Huntsville & $\mathrm{AL}$ & 238,912 & 145 & \\
\hline Tuscaloosa & $\mathrm{AL}$ & 150,522 & 188 & \\
\hline Decatur & $\mathrm{AL}$ & 131,556 & 212 & \\
\hline Florence & $\mathrm{AL}$ & 131,327 & 214 & \\
\hline Dothan & $\mathrm{AL}$ & 130,964 & 216 & \\
\hline Anniston & $\mathrm{AL}$ & 116,034 & 242 & \\
\hline Gadsden & $\mathrm{AL}$ & 99,840 & 260 & $2,676,405$ \\
\hline Little Rock-North Little Rock & $\mathrm{AR}$ & 513,117 & 73 & \\
\hline Fort Smith & AR & 175,911 & 170 & \\
\hline Fayetteville-Springdale & $\mathrm{AR}$ & 113,409 & 248 & \\
\hline Pine Bluff & $\mathrm{AR}$ & 85,487 & 270 & 887,924 \\
\hline Phoenix & $\mathrm{AZ}$ & $2,122,101$ & 20 & \\
\hline Tucson & $\mathrm{AZ}$ & 666,880 & 62 & $2,788,981$ \\
\hline Los Angeles-Anaheim-Riverside & $\mathrm{CA}$ & $14,531,529$ & 2 & \\
\hline San Francisco-Oakland-San Jose & CA & $6,253,311$ & 4 & \\
\hline San Diego & $\mathrm{CA}$ & $2,498,016$ & 15 & \\
\hline Sacramento & $\mathrm{CA}$ & $1,481,102$ & 26 & \\
\hline Fresno & $\mathrm{CA}$ & 667,490 & 61 & \\
\hline Bakersfield & $\mathrm{CA}$ & 543,477 & 71 & \\
\hline Stockton & $\mathrm{CA}$ & 480,628 & 78 & \\
\hline Modesto & $\mathrm{CA}$ & 370,522 & 98 & \\
\hline Santa Barbara-Santa Maria-Lompoc & CA & 369,608 & 99 & \\
\hline Salinas-Seaside-Monterey & $\mathrm{CA}$ & 355,660 & 104 & \\
\hline Visalia-Tulare-Porterville & $\mathrm{CA}$ & 311,921 & 119 & \\
\hline Chico & $\mathrm{CA}$ & 182,120 & 168 & \\
\hline Merced & $\mathrm{CA}$ & 178,403 & 169 & \\
\hline Redding & $\mathrm{CA}$ & 147,036 & 193 & \\
\hline Yuba City & $\mathrm{CA}$ & 122,643 & 228 & $28,493,466$ \\
\hline Denver-Boulder & $\mathrm{CO}$ & $1,848,319$ & 22 & \\
\hline Colorado Springs & $\mathrm{CO}$ & 397,014 & 91 & \\
\hline Fort Collins-Loveland & $\mathrm{CO}$ & 186,136 & 166 & \\
\hline Greeley & $\mathrm{CO}$ & 131,821 & 211 & \\
\hline Pueblo & $\mathrm{CO}$ & 123,051 & 227 & $2,686,341$ \\
\hline Hartford-New Britain-Middletown-Bristol & $\mathrm{CT}$ & $1,123,678$ & 35 & \\
\hline New Haven-Waterbury-Meriden & $\mathrm{CT}$ & 804,219 & 52 & \\
\hline New London-Norwich & $\mathrm{CT}$ & 254,957 & 134 & $2,182,854$ \\
\hline Washington & DC & $3,923,574$ & 7 & $3,923,574$ \\
\hline Miami-Fort Lauderdale & FL & $3,192,582$ & 11 & \\
\hline Tampa-St. Petersburg-Clearwater & FL & $2,067,959$ & 21 & \\
\hline Orlando & FL & $1,072,748$ & 36 & \\
\hline Jacksonville & FL & 906,727 & 47 & \\
\hline West Palm Beach-Boca Raton-Delray Beach & FL & 863,518 & 50 & \\
\hline Lakeland-Winter Haven & FL & 405,382 & 88 & \\
\hline Melbourne-Titusville-Palm Bay & FL & 398,978 & 90 & \\
\hline
\end{tabular}


Table A2 - 281 Metropolitan Areas by State

\begin{tabular}{|c|c|c|c|c|}
\hline & & 1990 & Pop. & State Metro \\
\hline Metropolitan Area & State & Population & Rank & Population \\
\hline Daytona Beach & FL & 370,712 & 97 & \\
\hline Pensacola & FL & 344,406 & 109 & \\
\hline Fort Myers-Cape Coral & FL & 335,113 & 113 & \\
\hline Sarasota & FL & 277,776 & 126 & \\
\hline Fort Pierce & FL & 251,071 & 136 & \\
\hline Tallahassee & FL & 233,598 & 146 & \\
\hline Bradenton & FL & 211,707 & 153 & \\
\hline Gainesville & FL & 204,111 & 156 & \\
\hline Ocala & FL & 194,833 & 158 & \\
\hline Naples & FL & 152,099 & 186 & \\
\hline Fort Walton Beach & FL & 143,776 & 198 & \\
\hline Panama City & FL & 126,994 & 223 & $11,754,090$ \\
\hline Atlanta & GA & $2,833,511$ & 12 & \\
\hline Augusta & GA & 396,809 & 92 & \\
\hline Macon-Warner Robins & GA & 281,103 & 123 & \\
\hline Columbus & GA & 243,072 & 140 & \\
\hline Savannah & GA & 242,622 & 141 & \\
\hline Athens & GA & 156,267 & 182 & \\
\hline Albany & GA & 112,561 & 249 & $4,265,945$ \\
\hline Honolulu & $\mathrm{HI}$ & 836,231 & 51 & 836,231 \\
\hline Des Moines & IA & 392,928 & 95 & \\
\hline Davenport-Rock Island-Moline & IA & 350,861 & 105 & \\
\hline Cedar Rapids & IA & 168,767 & 174 & \\
\hline Waterloo-Cedar Falls & IA & 146,611 & 194 & \\
\hline Sioux City & IA & 115,018 & 245 & \\
\hline Iowa City & IA & 96,119 & 265 & \\
\hline Dubuque & IA & 86,403 & 269 & $1,356,707$ \\
\hline Boise & ID & 205,775 & 155 & 205,775 \\
\hline Chicago-Gary-Lake County & IL & $8,065,633$ & 3 & \\
\hline Peoria & IL & 339,172 & 110 & \\
\hline Rockford & IL & 283,719 & 121 & \\
\hline Springfield & IL & 189,550 & 162 & \\
\hline Champaign-Urbana-Rantoul & IL & 173,025 & 172 & \\
\hline Bloomington-Normal & IL & 129,180 & 221 & \\
\hline Decatur & IL & 117,206 & 240 & \\
\hline Kankakee & IL & 96,255 & 264 & $9,393,740$ \\
\hline Indianapolis & IN & $1,249,822$ & 31 & \\
\hline Fort Wayne & $\mathrm{IN}$ & 363,811 & 101 & \\
\hline Evansville & IN & 278,990 & 124 & \\
\hline South Bend-Mishawaka & $\mathrm{IN}$ & 247,052 & 138 & \\
\hline Elkhart-Goshen & IN & 156,198 & 183 & \\
\hline Terre Haute & IN & 130,812 & 217 & \\
\hline Anderson & $\mathrm{IN}$ & 130,669 & 218 & \\
\hline Lafayette-West Lafayette & IN & 130,598 & 219 & \\
\hline Muncie & $\mathrm{IN}$ & 119,659 & 235 & \\
\hline Bloomington & IN & 108,978 & 252 & \\
\hline Kokomo & $\mathrm{IN}$ & 96,946 & 263 & $3,013,535$ \\
\hline Wichita & KS & 485,270 & 77 & \\
\hline
\end{tabular}

Table A2 - Page 2 
Table A2 - 281 Metropolitan Areas by State

\begin{tabular}{|c|c|c|c|c|}
\hline & & 1990 & Pop. & State Metro \\
\hline Metropolitan Area & State & Population & Rank & Population \\
\hline Topeka & KS & 160,976 & 179 & \\
\hline Lawrence & KS & 81,798 & 273 & 728,044 \\
\hline Louisville & KY & 952,662 & 42 & \\
\hline Lexington-Fayette & KY & 348,428 & 108 & \\
\hline Owensboro & KY & 87,189 & 268 & $1,388,279$ \\
\hline New Orleans & LA & $1,238,816$ & 32 & \\
\hline Baton Rouge & LA & 528,264 & 72 & \\
\hline Shreveport & LA & 334,341 & 114 & \\
\hline Lafayette & LA & 208,740 & 154 & \\
\hline Houma-Thibodaux & LA & 182,842 & 167 & \\
\hline Lake Charles & LA & 168,134 & 175 & \\
\hline Monroe & LA & 142,191 & 201 & \\
\hline Alexandria & LA & 131,556 & 212 & $2,934,884$ \\
\hline Boston-Lawrence-Salem-Lowell-Brockton & MA & $3,783,817$ & 9 & \\
\hline Worcester-Fitchburg-Leominster & MA & 709,705 & 57 & \\
\hline Springfield & MA & 602,878 & 68 & \\
\hline New Bedford-Fall River-Attleboro & MA & 506,325 & 75 & \\
\hline Pittsfield & MA & 139,352 & 204 & $5,742,077$ \\
\hline Baltimore & MD & $2,382,172$ & 18 & \\
\hline Hagerstown & MD & 121,393 & 231 & \\
\hline Cumberland & MD & 101,643 & 259 & $2,605,208$ \\
\hline Portland & $\mathrm{ME}$ & 243,135 & 139 & \\
\hline Bangor & $\mathrm{ME}$ & 146,601 & 195 & \\
\hline Lewiston-Auburn & $\mathrm{ME}$ & 105,259 & 257 & 494,995 \\
\hline Detroit-Ann Arbor & MI & $4,665,236$ & 6 & \\
\hline Grand Rapids & MI & 688,399 & 59 & \\
\hline Lansing-East Lansing & MI & 432,674 & 84 & \\
\hline Flint & MI & 430,459 & 85 & \\
\hline Saginaw-Bay City-Midland & MI & 399,320 & 89 & \\
\hline Kalamazoo & MI & 223,411 & 149 & \\
\hline Benton Harbor & MI & 161,378 & 177 & \\
\hline Muskegon & MI & 158,983 & 181 & \\
\hline Jackson & MI & 149,756 & 191 & \\
\hline Battle Creek & MI & 135,982 & 207 & $7,445,598$ \\
\hline Minneapolis-St. Paul & $\mathrm{MN}$ & $2,464,124$ & 16 & \\
\hline Duluth & MN & 239,971 & 144 & \\
\hline St. Cloud & MN & 190,921 & 160 & \\
\hline Rochester & MN & 106,470 & 256 & $3,001,486$ \\
\hline St. Louis & MO & $2,444,099$ & 17 & \\
\hline Kansas City & MO & $1,566,280$ & 25 & \\
\hline Springfield & MO & 240,593 & 143 & \\
\hline Joplin & MO & 134,910 & 209 & \\
\hline Columbia & MO & 112,379 & 250 & \\
\hline St. Joseph & $\mathrm{MO}$ & 83,083 & 272 & $4,581,344$ \\
\hline Jackson & MS & 395,396 & 93 & \\
\hline Biloxi-Gulfport & MS & 197,125 & 157 & \\
\hline Pascagoula & MS & 115,243 & 244 & 707,764 \\
\hline Billings & MT & 113,419 & 247 & \\
\hline
\end{tabular}

Table A2 - Page 3 
Table A2 - 281 Metropolitan Areas by State

\begin{tabular}{|c|c|c|c|c|}
\hline & & 1990 & Pop. & State Metro \\
\hline Metropolitan Area & State & Population & Rank & Population \\
\hline Great Falls & MT & 77,691 & 276 & 191,110 \\
\hline Charlotte-Gastonia-Rock Hill & $\mathrm{NC}$ & $1,162,093$ & 34 & \\
\hline Greensboro-Winston-Salem-High Point & $\mathrm{NC}$ & 942,091 & 44 & \\
\hline Raleigh-Durham & $\mathrm{NC}$ & 735,480 & 55 & \\
\hline Fayetteville & $\mathrm{NC}$ & 274,566 & 128 & \\
\hline Hickory & $\mathrm{NC}$ & 221,700 & 151 & \\
\hline Asheville & $\mathrm{NC}$ & 174,821 & 171 & \\
\hline Jacksonville & $\mathrm{NC}$ & 149,838 & 190 & \\
\hline Wilmington & $\mathrm{NC}$ & 120,284 & 233 & \\
\hline Burlington & $\mathrm{NC}$ & 108,213 & 254 & $3,889,086$ \\
\hline Fargo-Moorhead & ND & 153,296 & 185 & \\
\hline Bismarck & ND & 83,831 & 271 & \\
\hline Grand Forks & ND & 70,683 & 279 & 307,810 \\
\hline Omaha & $\mathrm{NE}$ & 618,262 & 65 & \\
\hline Lincoln & $\mathrm{NE}$ & 213,641 & 152 & 831,903 \\
\hline Portsmouth-Dover-Rochester & $\mathrm{NH}$ & 350,078 & 106 & \\
\hline Manchester-Nashua & $\mathrm{NH}$ & 336,073 & 112 & 686,151 \\
\hline Atlantic City & NJ & 319,416 & 115 & 319,416 \\
\hline Albuquerque & NM & 480,577 & 79 & \\
\hline Las Cruces & NM & 135,510 & 208 & \\
\hline Santa Fe & NM & 117,043 & 241 & 733,130 \\
\hline Las Vegas & NV & 741,459 & 691 & \\
\hline Reno & NV & 254,667 & 135 & 996,126 \\
\hline New York-Northern New Jersey-Long Island & NY & $17,953,372$ & 1 & \\
\hline Buffalo-Niagara Falls & NY & $1,189,288$ & 33 & \\
\hline Rochester & NY & $1,002,410$ & 38 & \\
\hline Albany-Schenechtady-Troy & NY & 874,304 & 48 & \\
\hline Syracuse & NY & 659,864 & 63 & \\
\hline Utica-Rome & NY & 316,633 & 116 & \\
\hline Binghamton & NY & 264,497 & 129 & \\
\hline Poughkeepsie & NY & 259,462 & 132 & \\
\hline Jamestown-Dunkirk & NY & 141,895 & 202 & \\
\hline Glens Falls & NY & 118,539 & 239 & \\
\hline Elmira & NY & 95,195 & 266 & $22,875,459$ \\
\hline Cleveland-Akron-Lorain & $\mathrm{OH}$ & $2,759,823$ & 13 & \\
\hline Cincinnati-Hamilton & $\mathrm{OH}$ & $1,744,124$ & 23 & \\
\hline Columbus & $\mathrm{OH}$ & $1,377,419$ & 29 & \\
\hline Dayton-Springfield & $\mathrm{OH}$ & 951,270 & 43 & \\
\hline Toledo & $\mathrm{OH}$ & 614,128 & 66 & \\
\hline Youngstown-Warren & $\mathrm{OH}$ & 492,619 & 76 & \\
\hline Canton & $\mathrm{OH}$ & 394,106 & 94 & \\
\hline Lima & $\mathrm{OH}$ & 154,340 & 184 & \\
\hline Steubenville-Weirton & $\mathrm{OH}$ & 142,523 & 199 & \\
\hline Mansfield & $\mathrm{OH}$ & 126,137 & 224 & $8,756,489$ \\
\hline Oklahoma City & $\mathrm{OK}$ & 958,839 & 41 & \\
\hline Tulsa & $\mathrm{OK}$ & 708,954 & 58 & \\
\hline Lawton & $\mathrm{OK}$ & 111,486 & 251 & \\
\hline Enid & $\mathrm{OK}$ & 56,735 & 281 & $1,836,014$ \\
\hline
\end{tabular}

Table A2 - Page 4 
Table A2 - 281 Metropolitan Areas by State

\begin{tabular}{|c|c|c|c|c|}
\hline & & 1990 & Pop. & State Metro \\
\hline Metropolitan Area & State & Population & Rank & Population \\
\hline Portland-Vancouver & OR & $1,477,895$ & 27 & \\
\hline Eugene-Springfield & OR & 282,912 & 122 & \\
\hline Salem & OR & 278,024 & 125 & \\
\hline Medford & OR & 146,389 & 196 & $2,185,220$ \\
\hline Philadelphia-Wilmington-Trenton & PA & $5,899,345$ & 5 & \\
\hline Pittsburgh-Beaver Valley & PA & $2,242,798$ & 19 & \\
\hline Scranton--Wilkes-Barre & PA & 734,175 & 56 & \\
\hline Allentown-Bethlehem & PA & 686,688 & 60 & \\
\hline Harrisburg-Lebanon-Carlisle & PA & 587,986 & 70 & \\
\hline Lancaster & PA & 422,822 & 86 & \\
\hline York & PA & 417,848 & 87 & \\
\hline Reading & PA & 336,523 & 111 & \\
\hline Erie & PA & 275,572 & 127 & \\
\hline Johnstown & PA & 241,247 & 142 & \\
\hline Altoona & PA & 130,542 & 220 & \\
\hline State College & PA & 123,786 & 226 & \\
\hline Sharon & PA & 121,003 & 232 & \\
\hline Williamsport & PA & 118,710 & 238 & $12,339,045$ \\
\hline Providence-Pawtucket-Woonsocket & RI & 916,270 & 45 & 916,270 \\
\hline Greenville-Spartanburg & $\mathrm{SC}$ & 640,861 & 64 & \\
\hline Charleston & $\mathrm{SC}$ & 506,875 & 74 & \\
\hline Columbia & $\mathrm{SC}$ & 453,331 & 81 & \\
\hline Anderson & $\mathrm{SC}$ & 145,196 & 197 & \\
\hline Florence & $\mathrm{SC}$ & 114,344 & 246 & $1,860,607$ \\
\hline Sioux Falls & SD & 123,809 & 225 & \\
\hline Rapid City & SD & 81,343 & 274 & 205,152 \\
\hline Nashville & $\mathrm{TN}$ & 985,026 & 39 & \\
\hline Memphis & TN & 981,747 & 40 & \\
\hline Knoxville & $\mathrm{TN}$ & 604,816 & 67 & \\
\hline Johnson City-Kingsport-Bristol & TN & 436,047 & 82 & \\
\hline Chattanooga & $\mathrm{TN}$ & 433,210 & 83 & \\
\hline Clarksville-Hopkinsville & $\mathrm{TN}$ & 169,439 & 173 & \\
\hline Jackson & $\mathrm{TN}$ & 77,982 & 275 & $3,688,267$ \\
\hline Dallas-Ft. Worth & TX & $3,885,415$ & 8 & \\
\hline Houston-Galveston-Brazoria & TX & $3,711,043$ & 10 & \\
\hline San Antonio & TX & $1,302,099$ & 30 & \\
\hline Austin & TX & 781,572 & 53 & \\
\hline El Paso & TX & 591,610 & 69 & \\
\hline McAllen-Edinburg-Mission & TX & 383,545 & 96 & \\
\hline Beaumont-Port Arthur & TX & 361,226 & 103 & \\
\hline Corpus Christi & TX & 349,894 & 107 & \\
\hline Brownsville-Harlingen & TX & 260,120 & 131 & \\
\hline Killeen-Temple & TX & 255,301 & 133 & \\
\hline Lubbock & TX & 222,636 & 150 & \\
\hline Waco & TX & 189,123 & 163 & \\
\hline Amarillo & TX & 187,547 & 165 & \\
\hline Longview-Marshall & TX & 162,431 & 176 & \\
\hline Tyler & TX & 151,309 & 187 & \\
\hline
\end{tabular}

Table A2 - Page 5 
Table A2 - 281 Metropolitan Areas by State

\begin{tabular}{|l|r|r|r|r|}
\hline & & \multicolumn{1}{|c|}{$\mathbf{1 9 9 0}$} & Pop. & State Metro \\
\hline \multicolumn{1}{|c|}{ Metropolitan Area } & State & Population & Rank & Population \\
\hline Laredo & TX & 133,239 & 210 & \\
\hline Wichita Falls & TX & 122,378 & 229 & \\
\hline Bryan-College Station & TX & 121,862 & 230 & \\
\hline Texarkana & TX & 120,132 & 234 & \\
\hline Abilene & TX & 119,655 & 236 & \\
\hline Odessa & TX & 118,934 & 237 & \\
\hline Midland & TX & 106,611 & 255 & \\
\hline San Angelo & TX & 98,458 & 261 & \\
\hline Sherman-Denison & TX & 95,021 & 267 & \\
\hline Victoria & TX & 74,361 & 277 & $13,905,522$ \\
\hline Salt Lake City-Ogden & UT & $1,072,227$ & 37 & \\
\hline Provo-Orem & UT & 263,590 & 130 & $1,335,817$ \\
\hline Norfolk-Virginia Beach-Newport News & VA & $1,396,107$ & 28 & \\
\hline Richmond-Petersburg & VA & 865,640 & 49 & \\
\hline Roanoke & VA & 224,477 & 148 & \\
\hline Lynchburg & VA & 142,199 & 200 & \\
\hline Charlottesville & VA & 131,107 & 215 & \\
\hline Danville & VA & 108,711 & 253 & $2,868,241$ \\
\hline Burlington & VT & 137,079 & 206 & 137,079 \\
\hline Seattle-Tacoma & WA & $2,559,164$ & 14 & \\
\hline Spokane & WA & 361,364 & 102 & \\
\hline Bremerton & WA & 189,731 & 161 & \\
\hline Yakima & WA & 188,823 & 164 & \\
\hline Olympia & WA & 161,238 & 178 & \\
\hline Richland-Kennewick-Pasco & WA & 150,033 & 189 & \\
\hline Bellingham & WA & 127,780 & 222 & $3,738,133$ \\
\hline Milwaukee-Racine & WI & $1,607,183$ & 24 & \\
\hline Madison & WI & 367,085 & 100 & \\
\hline Appleton-Oshkosh-Neenah & WI & 315,121 & 117 & \\
\hline Green Bay & WI & 194,594 & 159 & \\
\hline Janesville-Beloit & WI & 139,510 & 203 & \\
\hline Eau Claire & WI & 137,543 & 205 & \\
\hline Wausau & WI & 115,400 & 243 & \\
\hline Sheboygan & WY & 73,142 & 278 & \\
\hline La Crosse & WI & 103,877 & 258 & \\
\hline Huntington-Ashland & WI & 97,904 & 262 & $3,078,217$ \\
\hline Charleston & WV & 312,529 & 118 & \\
\hline Wheeling & WV & 250,454 & 137 & \\
\hline Parkersburg-Marietta & WV & 159,301 & 180 & \\
\hline Cheyenne & & & & 134,368 \\
\hline Casper & WV & 149,169 & 192 & 871,453 \\
\hline
\end{tabular}




\section{APPENDIX B -- SURVEY FORMS AND QUESTIONS}

Survey forms and questions are included in this Appendix for the following categories of respondents:

1. State and local waste management officials

2. Waste consumers/processors/haulers

Landfill operators

Garbage collection/hauling companies

Biomass power plants

Wood processing/recycling companies

3. Waste generators

Secondary wood processors

Pallet manufacturers/recyclers

Construction contractors

Demolition contractors

Urban tree and landscape residue generators 


\section{State and Local Waste Management Officials}

Hello (introduction). I'm doing a study of urban wood waste resources for the National Renewable Energy Laboratory. Do you have a few minutes to answer some quick questions?

Agency name:

Address:

Contact:

Phone number:

1. Do you compile data on the generation of solid waste in your state/county/city?

2. Does this include a separate category for wood waste?

3. What is the estimated quantity of wood waste generated in your state/county/city?

4. Do you consider this estimate accurate? Why or why not?

5. (If applicable) What methodology was used to obtain this estimate?

6. Are there any reports or written materials available that you could send me?

7. Is there a local consultant who has special expertise in this subject?

8. Does your state/county/city have regulations affecting wood waste disposal/recycling?

The metropolitan area I am interested in is - For that metropolitan area:

1. What are the major sources of wood wastes? (e.g., pallets, C/D wood, MSW wood)

2. Where is wood waste disposed of? (e.g., landfills, wood processors/recyclers)

3. What are the fees (tipping fees)?

4. Are there wood burning facilities in the area? (names, numbers)

5. Who are the major waste haulers and landfill operators? (names, numbers)

6. What agency would have data on housing starts? on industrial activity by SIC code?

7. What agency regulates waste grease disposal and recycling?

8. Do you have any suggestions on people I should contact, or approaches I should take? 


\section{Landfill Operators}

Hello (introduction). I'm doing a study of urban wood waste resources for the National Renewable Energy Laboratory. Do you have a few minutes to answer some quick questions?

Company name:

Address:

Contact:

Phone number:

1. Do you have any restrictions, or special handling, or special fees, for waste wood?

2. Do you have an estimate of how much wood enters your landfill per year?

3. What percentage of the total material entering your landfill would you estimate is wood?

4. What are the trends? More wood disposal or less wood disposal? Why?

5. What are the tipping fees that apply to wood wastes at your landfill? Trends?

6. What are the major sources of wood waste entering your landfill?

7. About how much of it is construction and demolition wood?

8. Tree trimmings, stumps, etc.?

9. Pallets?

10. Industrial wood scraps, sawdust, etc.?

11. Where else does wood waste go? (wood processors, etc.) (names, numbers)

12. Do you have any suggestions on how I should estimate the total amount of urban waste wood generated in the metropolitan area?

13. Do you have any suggestions on people I should contact, or approaches I should take? 


\section{Garbage Collection/Hauling Companies}

Hello (introduction). I'm doing a study of urban wood waste resources for the National Renewable Energy Laboratory. Do you have a few minutes to answer some quick questions?

Company name:

Address:

Contact:

Phone number:

1. Do you have any restrictions, or special handling, or special fees, for waste wood?

2. Do you have an estimate of how much waste wood you haul per year?

3. What percentage of the total material you haul would you estimate is wood?

4. What are the trends? More wood disposal or less wood disposal? Why?

5. What fees do you charge for hauling wood wastes? Are they increasing or decreasing?

6. What are the major sources of wood waste you haul?

7. About how much of it is construction and demolition wood?

8. Tree trimmings, stumps, etc.?

9. Pallets?

10. Industrial wood scraps, sawdust, etc.?

11. How much is the landfill tipping fee for wood?

12. Where else does wood waste go? (wood processors, etc.) (names, numbers)

13. Do you have any suggestions on how I should estimate the total amount of urban waste wood generated in the metropolitan area?

14. Do you have any suggestions on people I should contact, or approaches I should take? 


\section{Biomass Power Plants}

Hello (introduction). I'm doing a study of urban wood waste resources for the National Renewable Energy Laboratory. Do you have a few minutes to answer some quick questions?

Company name:

Address:

Contact:

Phone number:

1. How much wood does your plant consume per year? Is it increasing or decreasing?

2. What are the major types and sources of wood wastes you use?

3. Do your permits or equipment restrict you from using certain types of wood?

4. How much do you pay for wood? Are wood fuel prices increasing or decreasing?

5. Where else does wood waste go in your area? (names, numbers)

6. How do you feel about waste pallets as fuel?

7. Construction and demolition wood?

8. Urban tree trimmings?

9. Other wood wastes found in the municipal solid waste stream?

10. Do you have any suggestions on how I should estimate the total amount of urban waste wood generated in the metropolitan area?

11. Do you have any suggestions on people I should contact, or approaches I should take? 


\section{Wood Processing/Recycling Companies}

Hello (introduction). I'm doing a study of urban wood waste resources for the National Renewable Energy Laboratory. Do you have a few minutes to answer some quick questions?

Company name:

Address:

Contact:

Phone number:

1. How much wood does your plant process per year? Is it increasing or decreasing?

2. What are the major types and sources of wood wastes you accept?

3. Do your permits or equipment restrict you from using certain types of wood?

4. What tipping fees do you charge for waste wood? Are fees increasing or decreasing?

5. Where else does wood waste go in your area? (names, numbers)

6. Who are your largest competitors? (names, numbers)

7. How do you feel about waste pallets as feedstock?

8. Construction and demolition wood?

9. Urban tree trimmings? Stumps?

10. Other wood wastes found in the municipal solid waste stream?

11. What products do you sell? Amounts? Prices?

12. Do you send any wood waste to landfills or other disposal facilities?

13. Do you have any suggestions on how I should estimate the total amount of urban waste wood generated in the metropolitan area?

14. Do you have any suggestions on people I should contact, or approaches I should take? 


\section{Secondary Wood Processors}

Hello (introduction). I'm doing a study of urban wood waste resources for the National Renewable Energy Laboratory. Do you have a few minutes to answer some quick questions?

Company name:

Address:

Contact:

Phone number:

1. Do you have an estimate of how much waste wood you generate per year?

2. What forms does it take? (scraps, chips, sawdust, etc.)

3. How do you dispose of it? Who takes it? (names, numbers)

4. What are the trends? More wood disposal or less wood disposal? Why?

5. Are your wood wastes a revenue source or a cost? How much?

6. Where else does wood waste like yours go? (names, numbers)

7. Who are the biggest local generators of wood wastes? (names, numbers)

8. Do you have any suggestions on how I should estimate the total amount of secondary wood processing waste generated in the metropolitan area?

9. Do you have any suggestions on people I should contact, or approaches I should take? 


\section{Pallet Manufacturers/Recyclers}

Hello (introduction). I'm doing a study of urban wood waste resources for the National Renewable Energy Laboratory. Do you have a few minutes to answer some quick questions?

Company name:

Address:

Contact:

Phone number:

1. Do you have an estimate of how much waste wood you generate per year?

2. What forms does it take? (scraps, chips, sawdust, etc.)

3. How do you dispose of it? Who takes it? (names, numbers)

4. What are the trends? More pallet wood disposal or less? Why?

5. Are your wood wastes a revenue source or a cost? How much?

6. Where else does wood waste like yours go? (names, numbers)

7. Who are the biggest local generators of pallet wood wastes? (names, numbers)

8. What industries are your biggest customers for pallets?

9. How do they dispose of, or recycle, used pallets?

10. Do you have any suggestions on how I should estimate the total amount of waste wood generated from used pallets in the metropolitan area?

11. Do you have any suggestions on people I should contact, or approaches I should take? 


\section{Construction Contractors}

Hello (introduction). I'm doing a study of urban wood waste resources for the National Renewable Energy Laboratory. Do you have a few minutes to answer some quick questions?

Company name:

Address:

Contact:

Phone number:

1. Do you have an estimate of how much waste wood you generate per year?

2. What is the typical amount of wood waste produced for every house you build?

3. For every commercial building you build?

4. What forms does it take? (scraps, chips, sawdust, etc.)

5. Do you separate wood from other solid wastes at the job site?

6. How do you dispose of it? Who takes it? (names, numbers)

7. What are the trends? More construction wood disposal or less? Why?

8. Are your wood wastes a revenue source or a cost? How much?

9. Where else does wood waste like yours go? (names, numbers)

10. Who are the biggest construction contractors in the area? (names, numbers)

11. What about projects requiring remodeling or demolition of existing buildings?

12. Is demolition waste handled by your company or by a demolition contractor?

13. How do you dispose of it? Who takes it? (names, numbers)

14. What agency has statistics on the construction industry and activity in the area?

15. Do you have any suggestions on how I should estimate the total amount of construction and demolition wood waste generated in the metropolitan area?

16. Do you have any suggestions on people I should contact, or approaches I should take? 


\section{Demolition Contractors}

Hello (introduction). I'm doing a study of urban wood waste resources for the National Renewable Energy Laboratory. Do you have a few minutes to answer some quick questions?

Company name:

Address:

Contact:

Phone number:

1. Do you have an estimate of how much waste wood you generate per year?

2. What is the typical amount of wood waste produced for every house you demolish?

3. For every commercial building you demolish?

4. What forms does it take? (scraps, chips, sawdust, etc.)

5. Do you separate wood from other solid wastes at the job site?

6. How do you dispose of it? Who takes it? (names, numbers)

7. What are the trends? More demolition wood disposal or less? Why?

8. What disposal fees do you pay for demolition wood waste? Are they increasing?

9. Where else does wood waste like yours go? (names, numbers)

10. Who are the biggest demolition contractors in the area? (names, numbers)

11. What agency has statistics on the demolition industry and activity in the area?

12. Do you have any suggestions on how I should estimate the total amount of construction and demolition wood waste generated in the metropolitan area?

13. Do you have any suggestions on people I should contact, or approaches I should take? 


\section{Urban Tree and Landscape Residue Generators (Includes Utility Line Clearing Departments, Municipal Agencies, etc.)}

Hello (introduction). I'm doing a study of urban wood waste resources for the National Renewable Energy Laboratory. Do you have a few minutes to answer some quick questions?

Company name:

Address:

Contact:

Phone number:

1. Do you have an estimate of how much wood waste you generate per year?

2. What forms does it take? (chips, tops and limbs, stumps, etc.)

3. How do you dispose of it? Who takes it? (names, numbers)

4. What are the trends? More tree trimming wood disposal or less? Why?

5. What disposal fees do you pay for your wood waste? Are they increasing?

6. Where else does wood waste like yours go? (names, numbers)

7. Who are the biggest tree and landscape contractors in the area? (names, numbers)

8. What agency has statistics on the tree trimming and landscaping industry and activity in the area?

9. Do you have any suggestions on how I should estimate the total amount of tree trimming and landscape wood waste generated in the metropolitan area?

10. Do you have any suggestions on people I should contact, or approaches I should take? 


\section{APPENDIX C -- REGRESSION PLOTS}

This Appendix presents a series of regression plots and statistical analyses, as discussed in Section B. The first six plots analyze the wood resource data from the full set of 30 cities. The next six plots analyze the wood resource data from 28 cities, with two "outliers" removed. All of the regression equations were specified to go through the origin, based on the assumption that a city with zero population would generate no urban wood wastes. 
MSW Wood vs. Population: 30 Cities

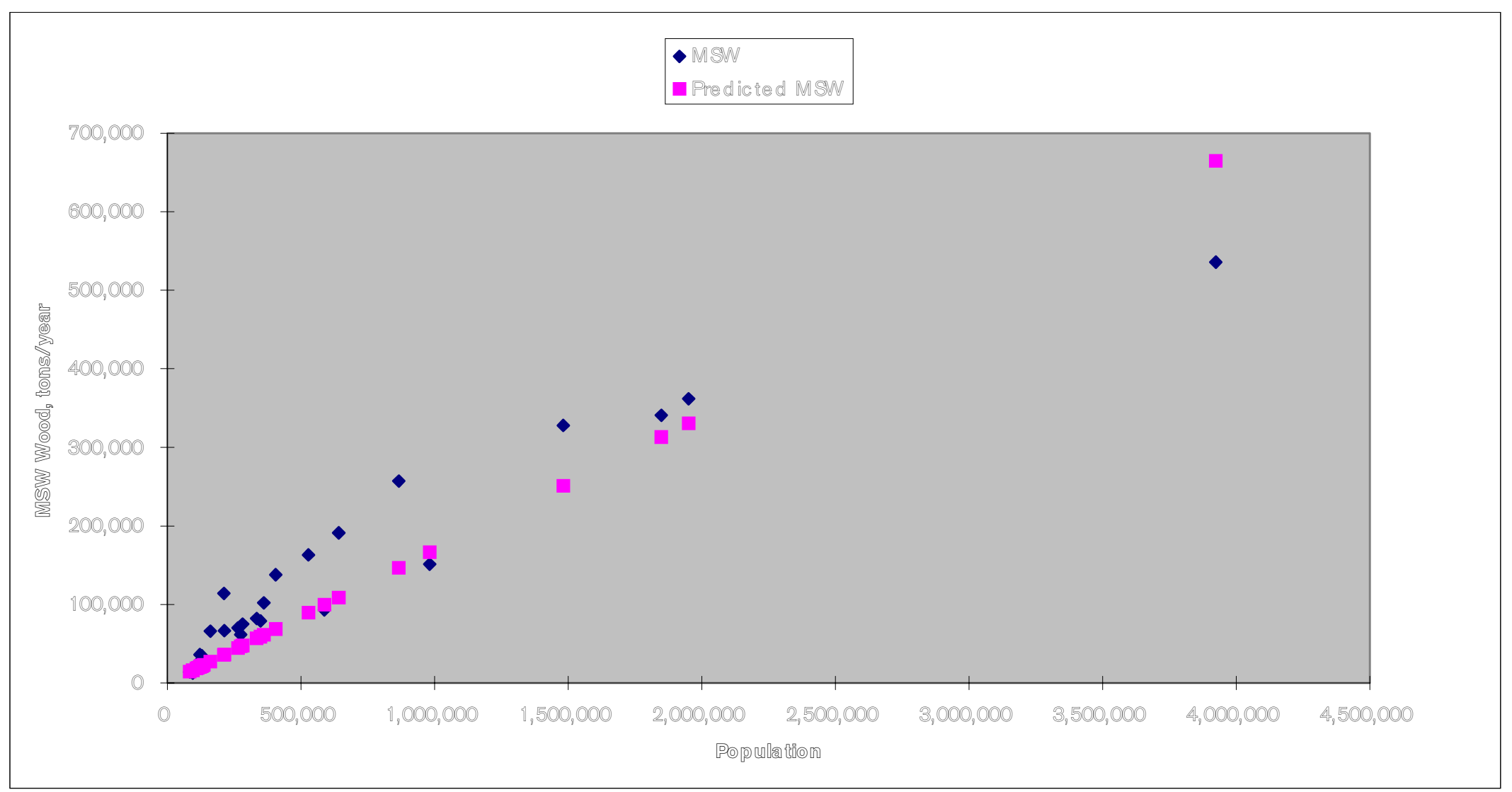

\begin{tabular}{lr}
\hline \multicolumn{2}{c}{ Regression Statistics } \\
\hline Multiple R & 0.92571516 \\
R Square & 0.85694856 \\
Adjusted R Square & 0.82246581 \\
Standard Error & 48124.4828 \\
Observations & 30 \\
\hline
\end{tabular}

ANOVA

\begin{tabular}{|c|c|c|c|c|c|c|}
\hline & $d f$ & & $S S$ & $M S$ & $F$ & Significance $F$ \\
\hline Regression & & 1 & $4.0234 \mathrm{E}+11$ & $4.0234 \mathrm{E}+11$ & 173.724285 & $1.5784 \mathrm{E}-13$ \\
\hline Residual & & 29 & $6.7163 \mathrm{E}+10$ & 2315965843 & & \\
\hline Total & & 30 & $4.695 \mathrm{E}+11$ & & & \\
\hline
\end{tabular}

\begin{tabular}{lrccccccc}
\hline & Coefficients & Standard Error & t Stat & P-value & Lower 95\% & Upper 95\% & Lower 95.0\% & Upper 95.0\% \\
\hline Intercept & 0 & \#N/A & \#N/A & \#N/A & \#N/A & \#N/A & \#N/A & \#N/A \\
Population & 0.16950872 & 0.00900141 & 18.8313546 & $8.3394 \mathrm{E}-18$ & 0.15109876 & 0.18791867 & 0.15109876 & 0.18791867 \\
\hline \multicolumn{10}{c}{ C-2 } & \multicolumn{1}{c}{}
\end{tabular}


Industrial Wood vs. Population: 30 Cities

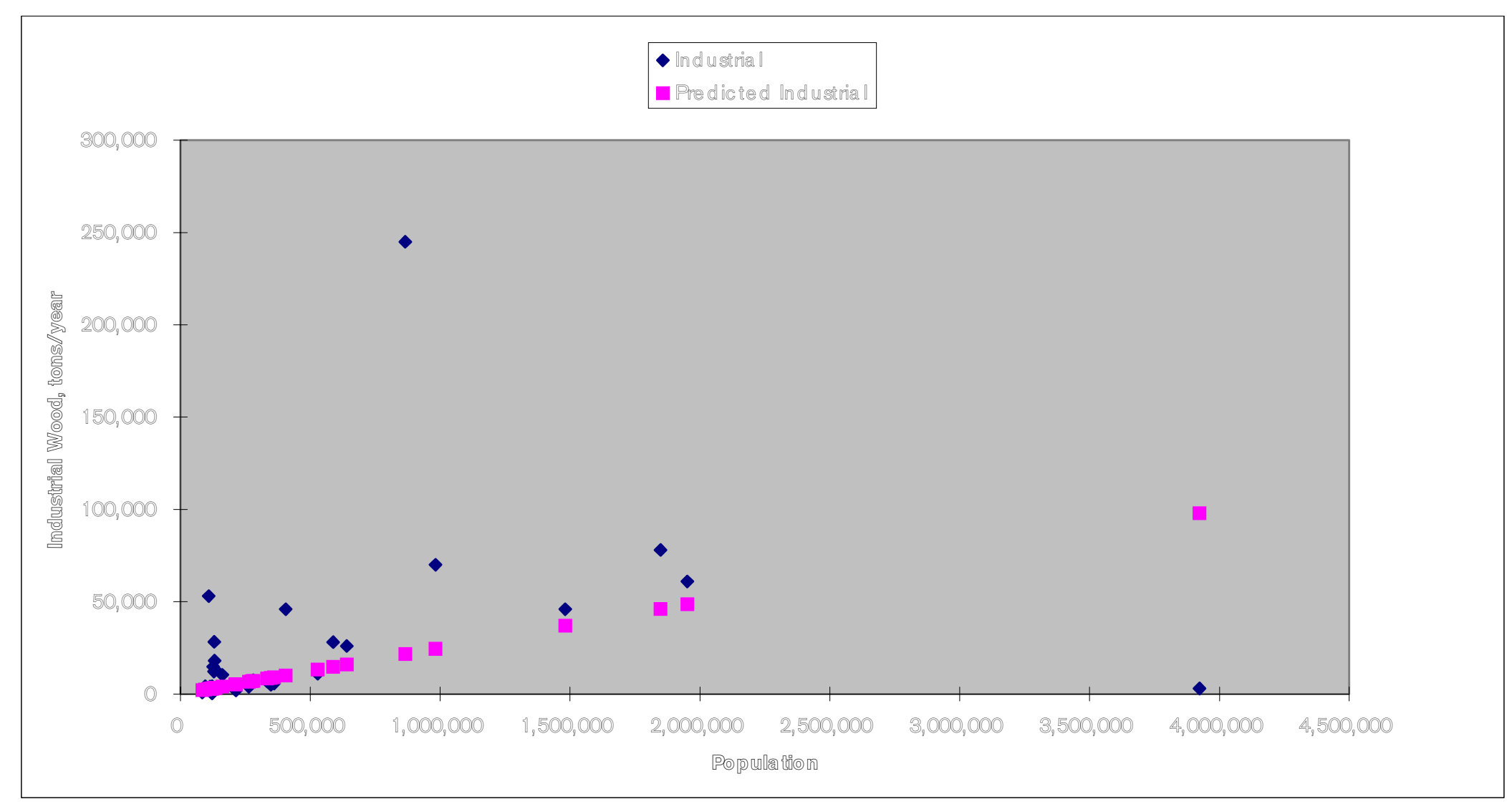

\begin{tabular}{lr}
\hline \multicolumn{2}{c}{ Regression Statistics } \\
\hline Multiple R & 0 \\
R Square & -0.0714877 \\
Adjusted R Square & -0.1059705 \\
Standard Error & 48278.6029 \\
Observations & 30 \\
\hline
\end{tabular}

ANOVA

\begin{tabular}{lrrrrc}
\hline & $d f$ & \multicolumn{1}{c}{$S S$} & \multicolumn{1}{c}{$M S$} & $F$ & Significance $F$ \\
\hline Regression & 1 & $-4.51 \mathrm{E}+09$ & $-4.51 \mathrm{E}+09$ & -1.9348268 & \#NUM! \\
Residual & 29 & $6.7594 \mathrm{E}+10$ & 2330823503 & & \\
Total & 30 & $6.3084 \mathrm{E}+10$ & & & \\
\hline
\end{tabular}

\begin{tabular}{lcccccccc}
\hline \multicolumn{10}{c}{} \\
\hline \multicolumn{10}{c}{ Coefficients } & Standard Error & t Stat & P-value & Lower 95\% & Upper 95\% & Lower 95.0\% & Upper 95.0\% \\
\hline Intercept & 0 & \#N/A & \#N/A & \#N/A & \#N/A & \#N/A & \#N/A & \#N/A \\
Population & 0.02497803 & 0.00903024 & 2.76604397 & 0.00976958 & 0.00650911 & 0.04344695 & 0.00650911 & 0.04344695 \\
\hline \multicolumn{10}{c}{ C-3 }
\end{tabular}


C/D Wood vs. Population: 30 Cities

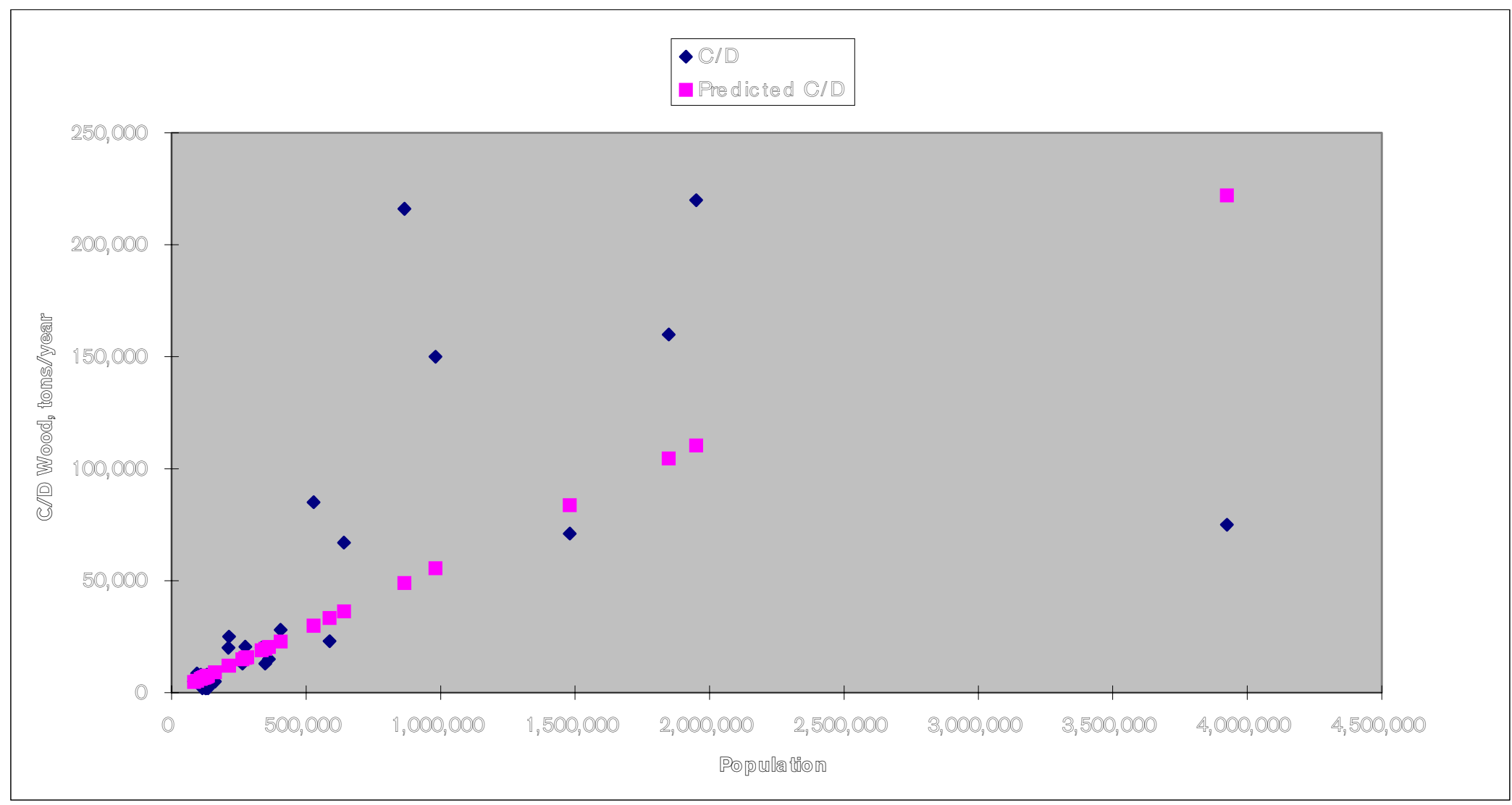

\begin{tabular}{lr}
\hline \multicolumn{2}{c}{ Regression Statistics } \\
\hline Multiple R & 0.56025468 \\
R Square & 0.3138853 \\
Adjusted R Square & 0.27940254 \\
Standard Error & 51959.9756 \\
Observations & 30 \\
\hline
\end{tabular}

ANOVA

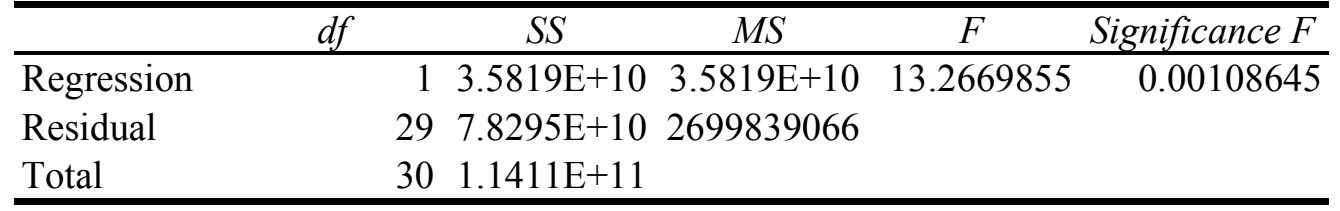

\begin{tabular}{|c|c|c|c|c|c|c|c|c|}
\hline & Coefficients & Standard Error & $t$ Stat & $P$-value & Lower 95\% & Upper 95\% & Lower $95.0 \%$ & Upper $95.0 \%$ \\
\hline Intercept & 0 & $\# \mathrm{~N} / \mathrm{A}$ & $\# \mathrm{~N} / \mathrm{A}$ & $\# \mathrm{~N} / \mathrm{A}$ & $\# \mathrm{~N} / \mathrm{A}$ & $\# \mathrm{~N} / \mathrm{A}$ & $\# \mathrm{~N} / \mathrm{A}$ & $\# \mathrm{~N} / \mathrm{A}$ \\
\hline Population & 0.05658817 & 0.00971882 & 5.82253741 & $2.5946 \mathrm{E}-06$ & 0.03671095 & 0.07646539 & 0.03671095 & 0.07646539 \\
\hline
\end{tabular}


Total Wood vs. Population: 30 Cities

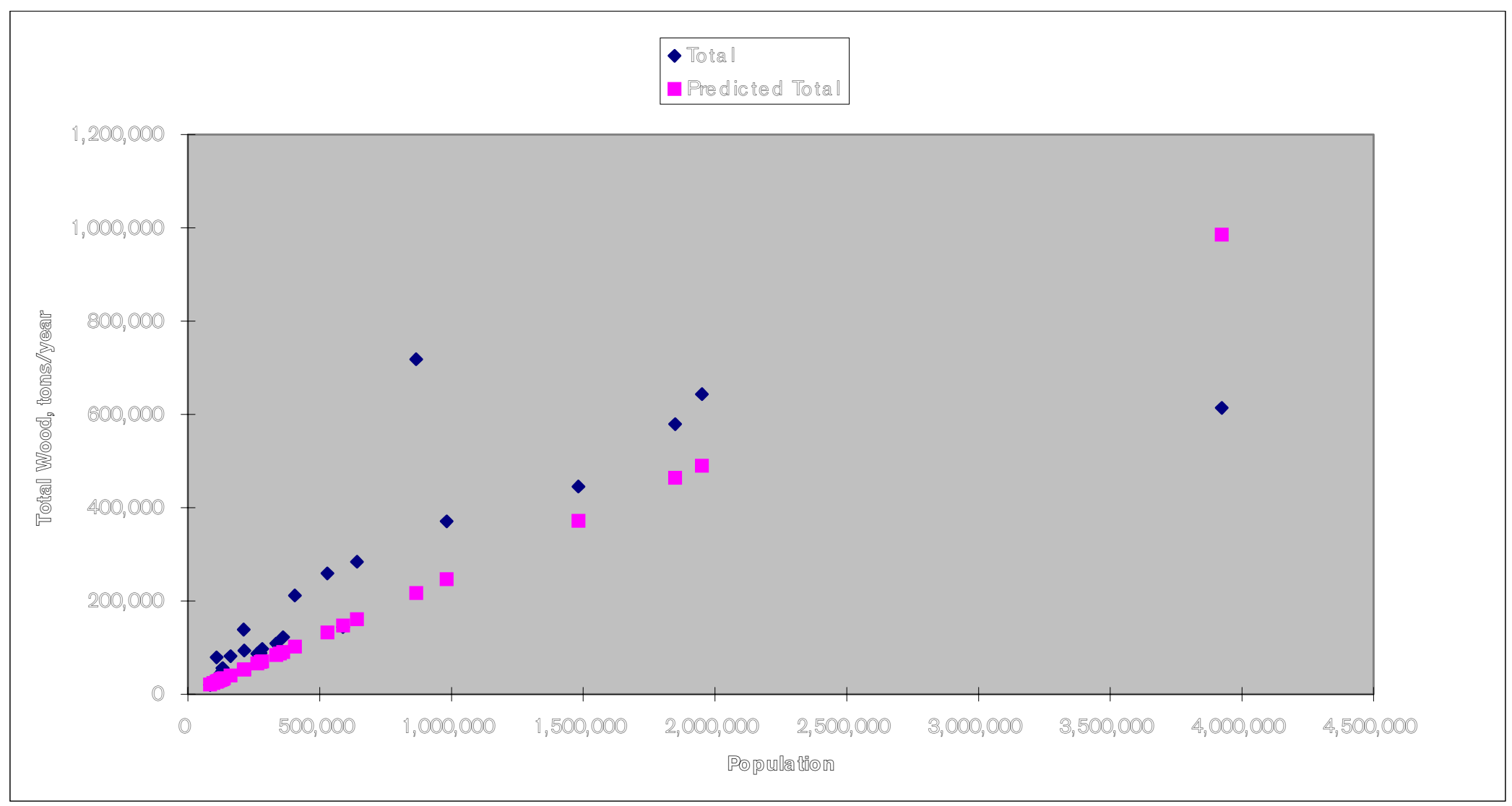

\begin{tabular}{lr}
\hline \multicolumn{2}{c}{ Regression Statistics } \\
\hline Multiple R & 0.76923284 \\
R Square & 0.59171917 \\
Adjusted R Square & 0.55723641 \\
Standard Error & 132262.157 \\
Observations & 30 \\
\hline
\end{tabular}

ANOVA

\begin{tabular}{|c|c|c|c|c|c|}
\hline & $\overline{d f}$ & $S S$ & $M S$ & $F$ & Significance $F$ \\
\hline$\overline{\text { Regression }}$ & 1 & $7.3523 \mathrm{E}+11$ & $7.3523 \mathrm{E}+11$ & 42.0295405 & $5.04 \mathrm{E}-07$ \\
\hline Residual & 29 & $5.0731 \mathrm{E}+11$ & $1.7493 \mathrm{E}+10$ & & \\
\hline Total & 30 & $1.2425 \mathrm{E}+12$ & & & \\
\hline
\end{tabular}


C/D Wood vs. Housing Permits: 30 Cities

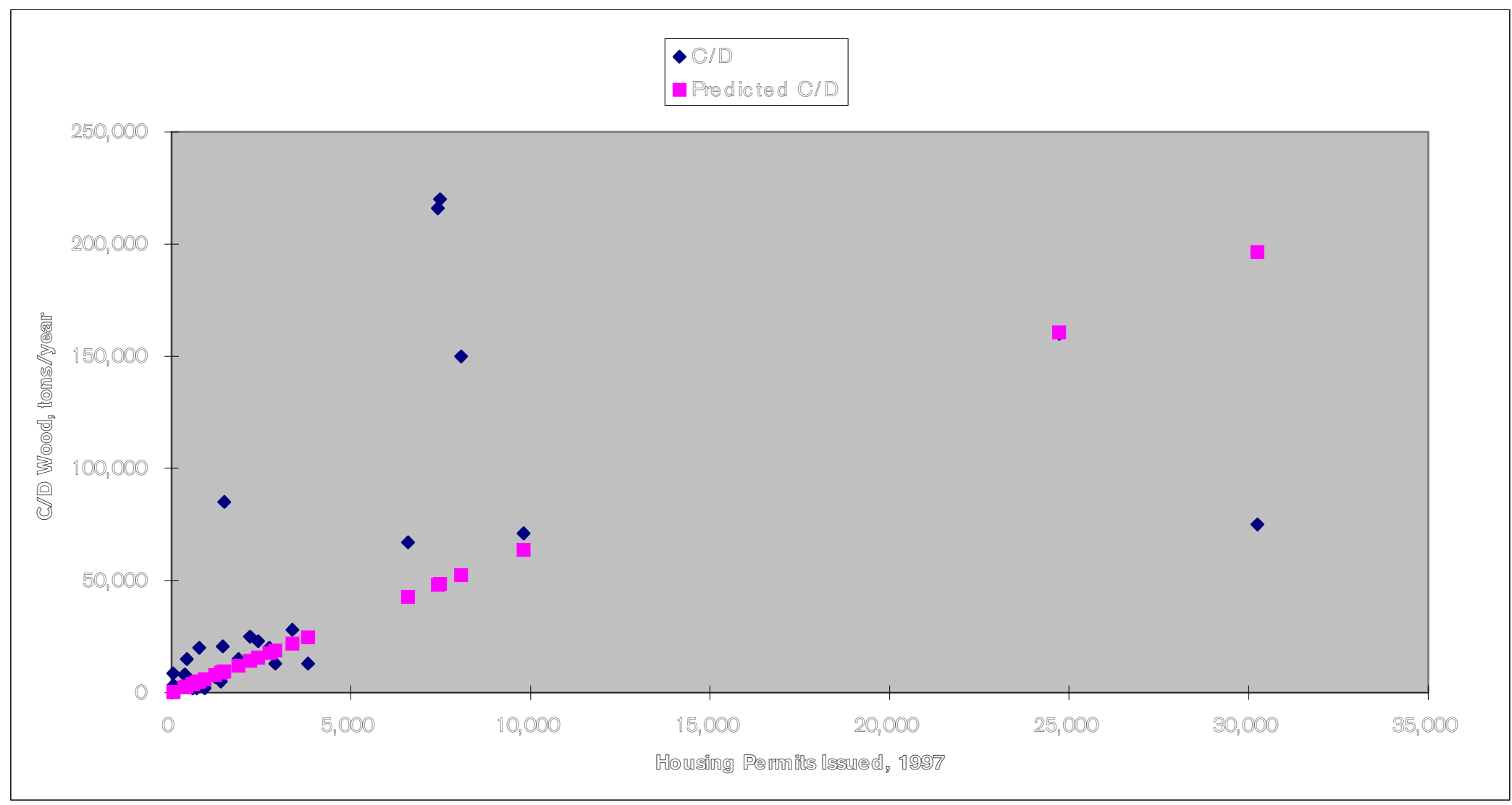

\begin{tabular}{lr}
\hline \multicolumn{2}{c}{ Regression Statistics } \\
\hline Multiple R & 0.46685726 \\
R Square & 0.2179557 \\
Adjusted R Square & 0.18347294 \\
Standard Error & 55473.5877 \\
Observations & 30 \\
\hline
\end{tabular}

ANOVA

\begin{tabular}{lrrcrr}
\hline & $d f$ & \multicolumn{1}{c}{$S S$} & $M S$ & $F$ & Significance $F$ \\
\hline Regression & 1 & $2.4872 \mathrm{E}+10$ & $2.4872 \mathrm{E}+10$ & 8.08229826 & 0.00825284 \\
Residual & 29 & $8.9242 \mathrm{E}+10$ & 3077318937 & & \\
Total & 30 & $1.1411 \mathrm{E}+11$ & & & \\
\hline
\end{tabular}

\begin{tabular}{|c|c|c|c|c|c|c|c|c|}
\hline & Coefficients & Standard Error & $t$ Stat & $P$-value & Lower 95\% & Upper 95\% & Lower $95.0 \%$ & Upper $95.0 \%$ \\
\hline Intercept & 0 & $\# \mathrm{~N} / \mathrm{A}$ & $\# \mathrm{~N} / \mathrm{A}$ & $\# \mathrm{~N} / \mathrm{A}$ & $\# \mathrm{~N} / \mathrm{A}$ & $\# \mathrm{~N} / \mathrm{A}$ & $\# \mathrm{~N} / \mathrm{A}$ & $\# \mathrm{~N} / \mathrm{A}$ \\
\hline Permits & 6.4964134 & 1.26951706 & 5.11723207 & $1.8312 \mathrm{E}-05$ & 3.89995806 & 9.09286873 & 3.89995806 & 9.09286873 \\
\hline
\end{tabular}


Housing Permits vs. Population: 30 Cities

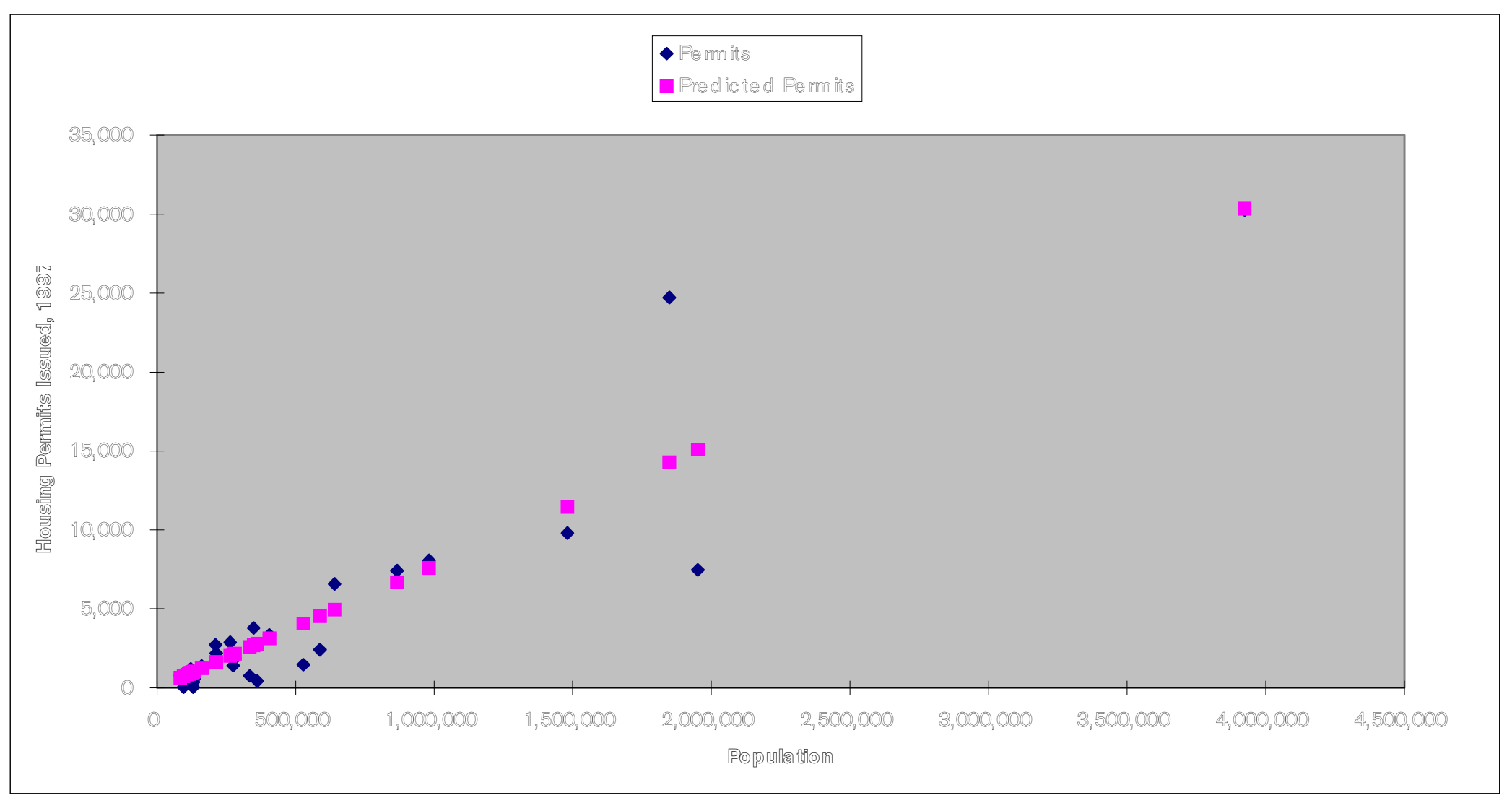

\begin{tabular}{lr}
\hline \multicolumn{2}{c}{ Regression Statistics } \\
\hline Multiple R & 0.92508723 \\
R Square & 0.85578638 \\
Adjusted R Square & 0.82130362 \\
Standard Error & 2625.39531 \\
Observations & 30 \\
\hline
\end{tabular}

ANOVA

\begin{tabular}{|c|c|c|c|c|c|}
\hline & $d f$ & $S S$ & $M S$ & $F$ & Significance $F$ \\
\hline Regression & & 11186168803 & 1186168803 & 172.090576 & 1.76983E-13 \\
\hline Residual & & $29 \quad 199888315$ & 6892700.52 & & \\
\hline Total & & $30 \quad 1386057119$ & & & \\
\hline
\end{tabular}

\begin{tabular}{|c|c|c|c|c|c|c|c|c|}
\hline & Coefficients & Standard Error & $t$ Stat & $P$-value & Lower 95\% & Upper 95\% & Lower $95.0 \%$ & Upper $95.0 \%$ \\
\hline Intercept & 0 & $\# \mathrm{~N} / \mathrm{A}$ & $\# \mathrm{~N} / \mathrm{A}$ & $\# \mathrm{~N} / \mathrm{A}$ & $\# \mathrm{~N} / \mathrm{A}$ & $\# \mathrm{~N} / \mathrm{A}$ & $\# \mathrm{~N} / \mathrm{A}$ & $\# \mathrm{~N} / \mathrm{A}$ \\
\hline Population & 0.00773356 & 0.00049107 & 15.7485473 & $9.5021 \mathrm{E}-16$ & 0.00672922 & 0.0087379 & 0.00672922 & 0.0087379 \\
\hline
\end{tabular}


MSW Wood vs. Population: 28 Cities

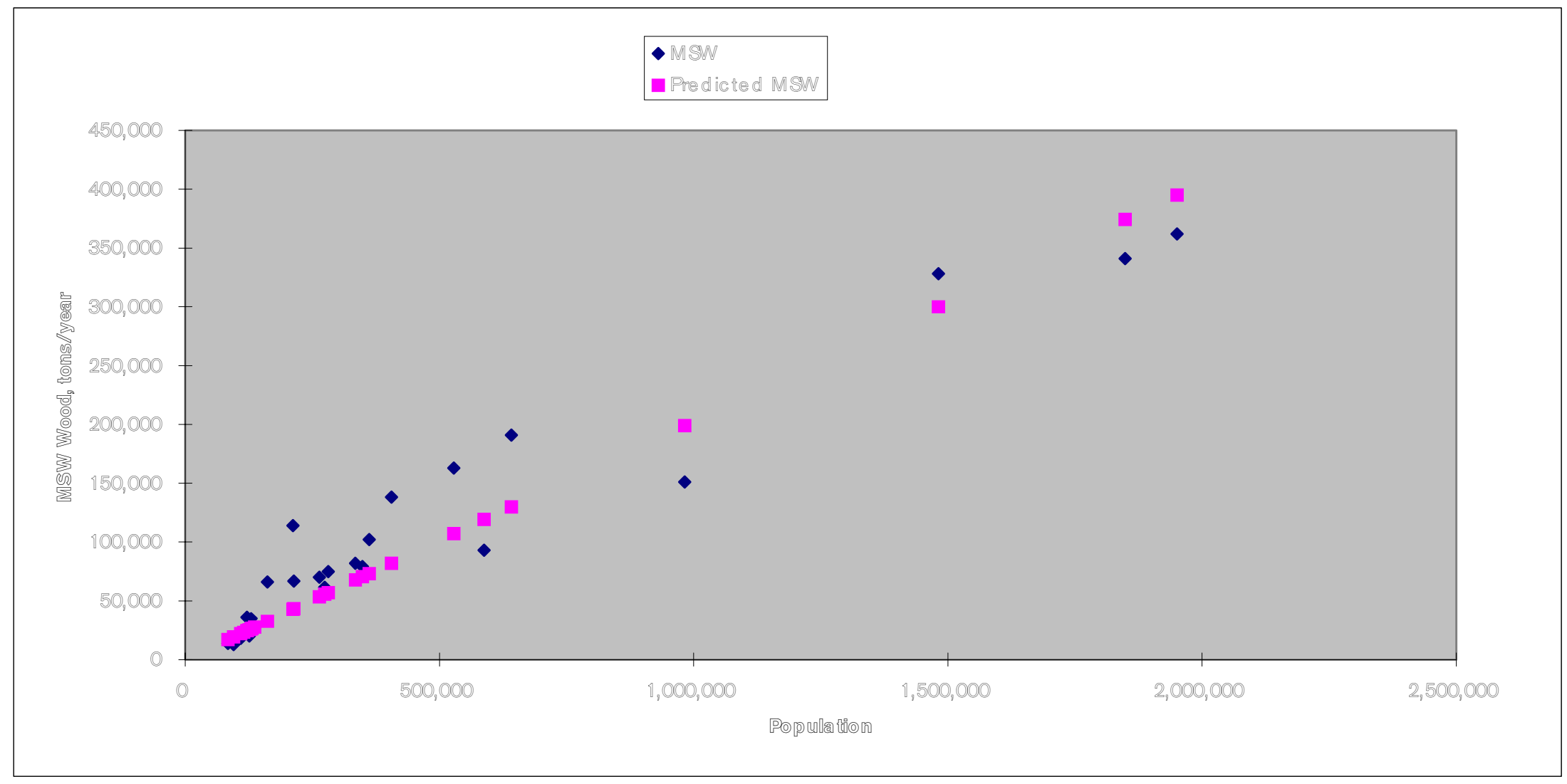

\begin{tabular}{|c|c|c|c|c|c|c|c|}
\hline \multicolumn{2}{|c|}{ Regression Statistics } & \multicolumn{6}{|l|}{ ANOVA } \\
\hline$\overline{\text { Multiple R }}$ & 0.9520546 & & & $S S$ & $M S$ & $F$ & Significance $F$ \\
\hline R Square & 0.9064079 & Regression & 1 & $2.398 \mathrm{E}+11$ & $2.398 \mathrm{E}+11$ & 261.48595 & $4.385 \mathrm{E}-15$ \\
\hline Adjusted R Square & 0.8693709 & Residual & 27 & $2.476 \mathrm{E}+10$ & 917146967 & & \\
\hline Standard Error & 30284.434 & Total & 28 & $2.646 \mathrm{E}+11$ & & & \\
\hline
\end{tabular}

Observations 28

\begin{tabular}{lrccccccc}
\hline & Coefficients & Standard Error & $t$ Stat & P-value & Lower 95\% & Upper 95\% & Lower 95.0\% & Upper 95.0\% \\
\hline Intercept & 0 & $\# \mathrm{~N} / \mathrm{A}$ & $\# \mathrm{~N} / \mathrm{A}$ & $\# \mathrm{~N} / \mathrm{A}$ & $\# \mathrm{~N} / \mathrm{A}$ & $\# \mathrm{~N} / \mathrm{A}$ & $\# \mathrm{~N} / \mathrm{A}$ & $\# \mathrm{~N} / \mathrm{A}$ \\
Population & 0.202549 & 0.0085866 & 23.589105 & $1.494 \mathrm{E}-19$ & 0.1849309 & 0.2201672 & 0.1849309 & 0.2201672 \\
\hline
\end{tabular}


Industrial Wood vs. Population: 28 Cities

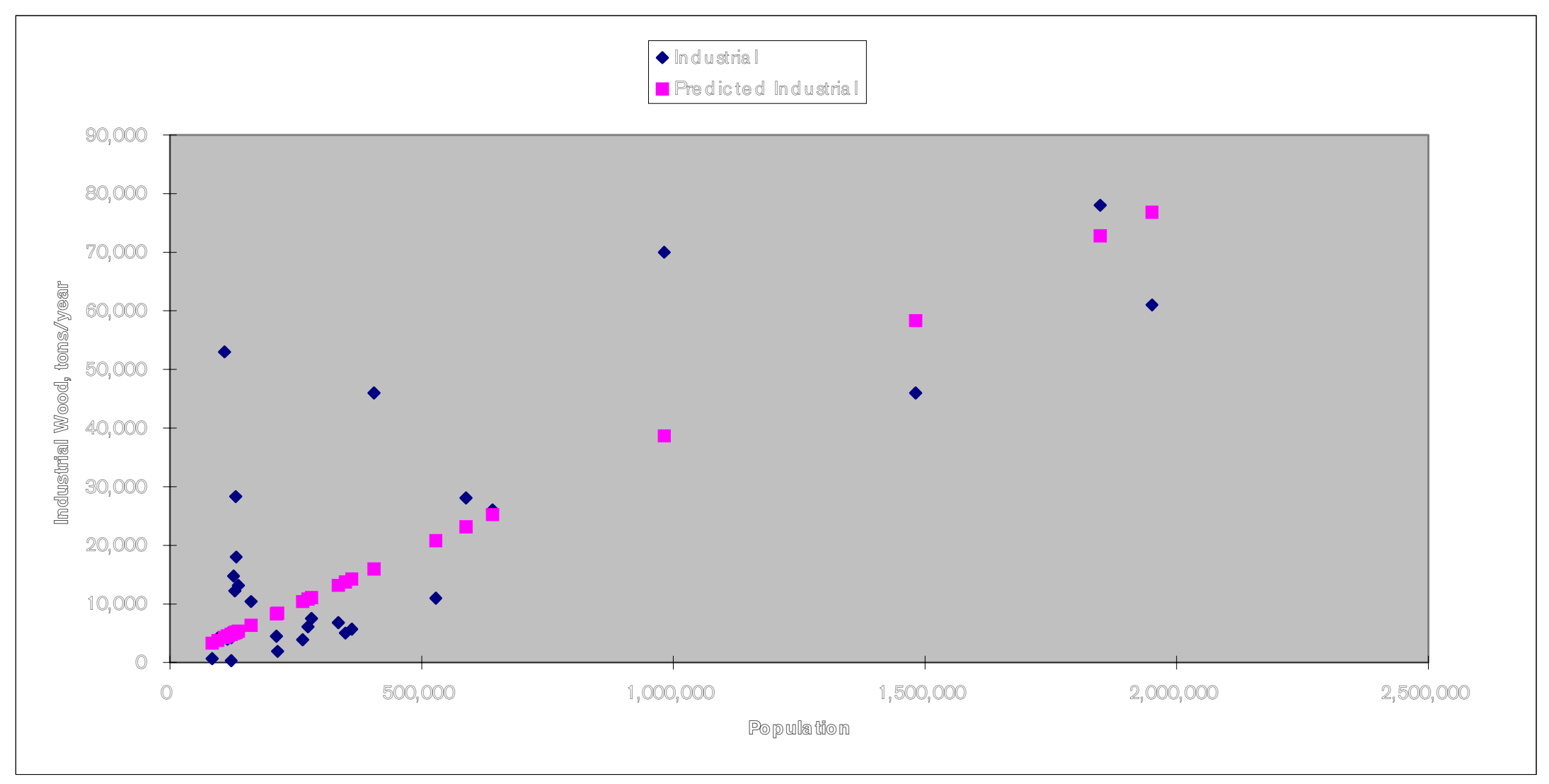

\begin{tabular}{lr}
\hline \multicolumn{2}{c}{ Regression Statistics } \\
\hline Multiple R & 0.7469213 \\
R Square & 0.5578914 \\
Adjusted R Square & 0.5208544 \\
Standard Error & 15010.665 \\
Observations & 28 \\
\hline
\end{tabular}

\begin{tabular}{lrrccr} 
ANOVA & \multicolumn{1}{c}{$S S$} & $M S$ & $F$ & Significance $F$ \\
\hline Regression & 1 & $7.677 \mathrm{E}+09$ & $7.677 \mathrm{E}+09$ & 34.070967 & $3.752 \mathrm{E}-06$ \\
Residual & 27 & $6.084 \mathrm{E}+09$ & 225320060 & & \\
Total & 28 & $1.376 \mathrm{E}+10$ & & & \\
\hline
\end{tabular}

\begin{tabular}{lrccccccc}
\hline & Coefficients & Standard Error & t Stat & P-value & Lower 95\% & Upper 95\% & Lower 95.0\% & Upper 95.0\% \\
\hline Intercept & 0 & \#N/A & \#N/A & \#N/A & \#N/A & \#N/A & \#N/A & \#N/A \\
Population & 0.0393988 & 0.004256 & 9.2572951 & $7.239 \mathrm{E}-10$ & 0.0306663 & 0.0481314 & 0.0306663 & 0.0481314 \\
\hline
\end{tabular}


C/D Wood vs. Population: 28 Cities

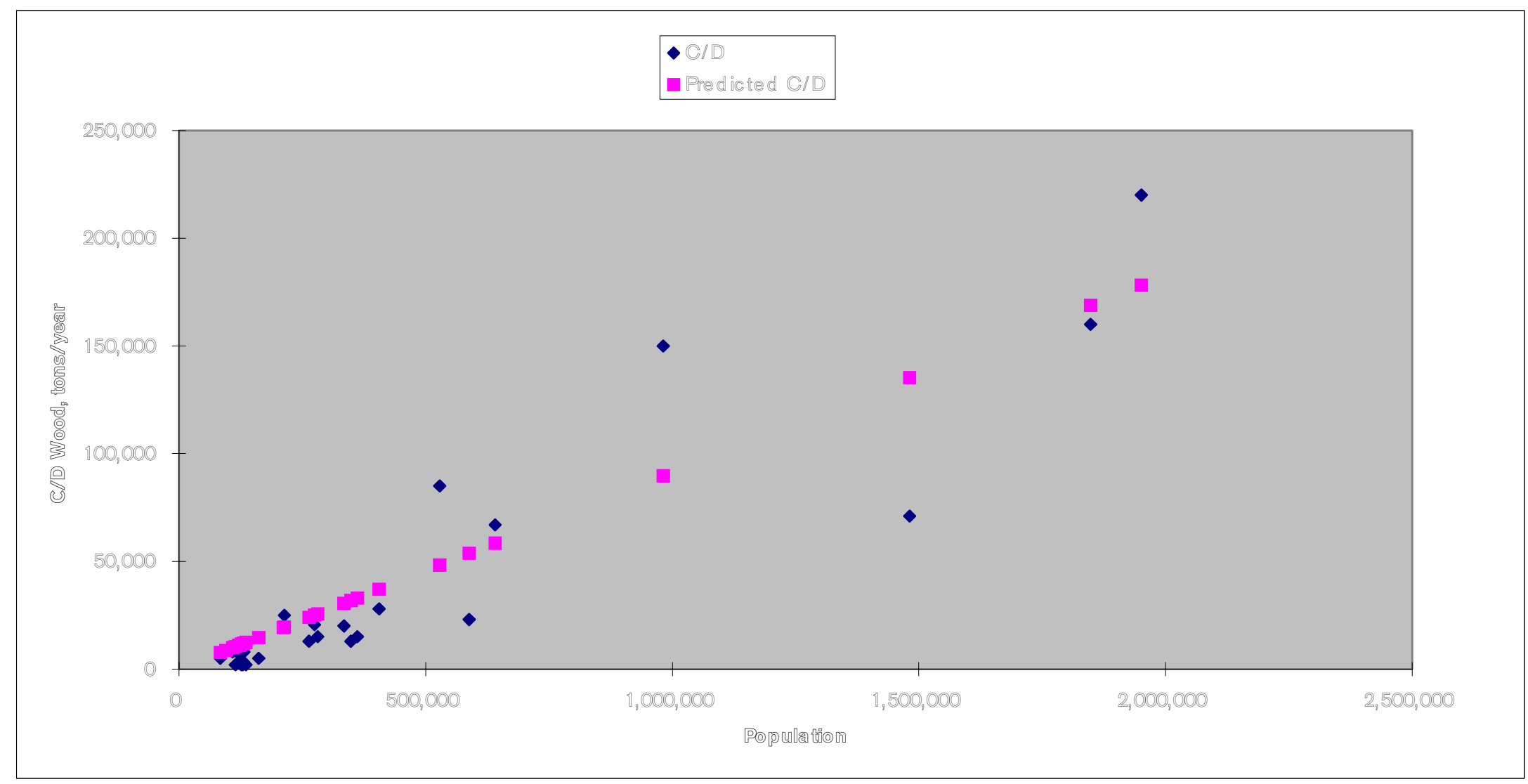

\begin{tabular}{lr}
\hline \multicolumn{2}{c}{ Regression Statistics } \\
\hline Multiple R & 0.911906 \\
R Square & 0.8315726 \\
Adjusted R Square & 0.7945356 \\
Standard Error & 22575.562 \\
Observations & 28 \\
\hline
\end{tabular}

ANOVA

\begin{tabular}{lrrrrr}
\hline & $d f$ & \multicolumn{1}{c}{$S S$} & $M S$ & $F$ & Significance $F$ \\
\hline Regression & 1 & $6.794 \mathrm{E}+10$ & $6.794 \mathrm{E}+10$ & 133.30646 & $9.809 \mathrm{E}-12$ \\
Residual & 27 & $1.376 \mathrm{E}+10$ & 509655981 & & \\
Total & 28 & $8.17 \mathrm{E}+10$ & & & \\
\hline
\end{tabular}

Coefficients Standard Error

Intercept

0

0.0913405

0.0064009

\begin{tabular}{lccccc}
$t$ Stat & $P$-value & Lower 95\% & Upper 95\% & Lower 95.0\% & Upper 95.0\% \\
\hline \#N/A & \#N/A & \#N/A & \#N/A & \#N/A & \#N/A \\
14.270047 & $4.278 \mathrm{E}-14$ & 0.078207 & 0.1044739 & 0.078207 & 0.1044739 \\
\hline
\end{tabular}

P-value

\begin{tabular}{lccccc}
$t$ Stat & $P$-value & Lower 95\% & Upper 95\% & Lower 95.0\% & Upper 95.0\% \\
\hline \#N/A & \#N/A & \#N/A & \#N/A & \#N/A & \#N/A \\
14.270047 & $4.278 \mathrm{E}-14$ & 0.078207 & 0.1044739 & 0.078207 & 0.1044739 \\
\hline
\end{tabular}

\section{C-10}


Total Wood vs. Population: 28 Cities

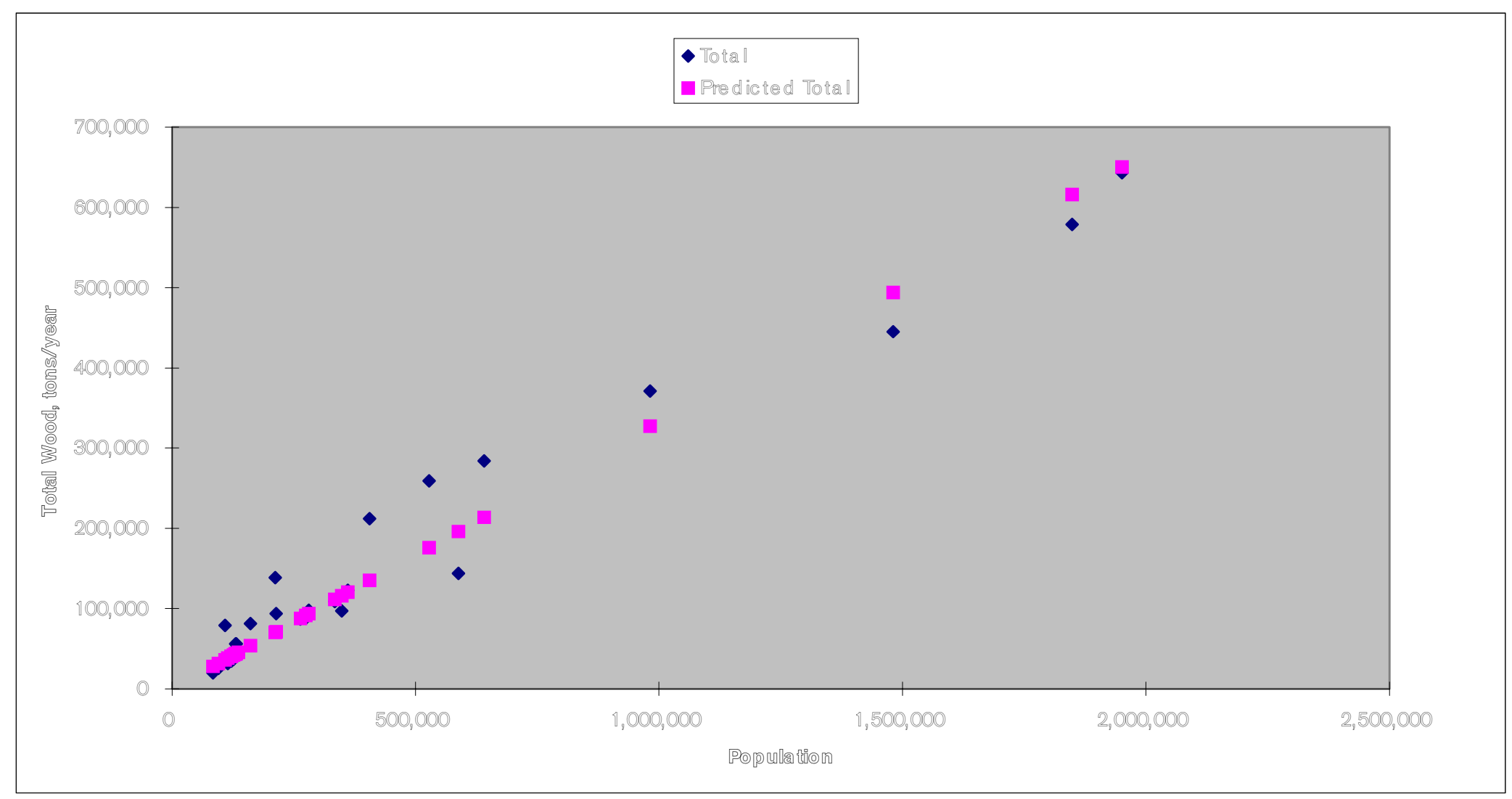

\begin{tabular}{|c|c|c|c|c|c|c|c|c|}
\hline \multicolumn{2}{|c|}{ Regression Statistics } & & \multicolumn{6}{|l|}{ ANOVA } \\
\hline Multiple R & 0.9764527 & & & $d f$ & $S S$ & $M S$ & $F$ & Significance $F$ \\
\hline R Square & 0.9534599 & & Regression & 1 & $7.138 \mathrm{E}+11$ & $7.138 \mathrm{E}+11$ & 553.14514 & $4.76 \mathrm{E}-19$ \\
\hline Adjusted R Square & 0.9164229 & & Residual & 27 & $3.484 \mathrm{E}+10$ & $1.29 \mathrm{E}+09$ & & \\
\hline Standard Error & 35923.195 & & Total & 28 & $7.487 \mathrm{E}+11$ & & & \\
\hline \multirow[t]{2}{*}{ Observations } & 28 & & & & & & & \\
\hline & Coefficients & Standard Error & $t$ Stat & P-value & Lower 95\% & Upper 95\% & Lower $95.0 \%$ & Upper $95.0 \%$ \\
\hline Intercept & 0 & $\# \mathrm{~N} / \mathrm{A}$ & $\# \mathrm{~N} / \mathrm{A}$ & $\# \mathrm{~N} / \mathrm{A}$ & $\# \mathrm{~N} / \mathrm{A}$ & $\# \mathrm{~N} / \mathrm{A}$ & $\# \mathrm{~N} / \mathrm{A}$ & $\# \mathrm{~N} / \mathrm{A}$ \\
\hline Population & 0.3332883 & 0.0101853 & 32.722457 & $2.91 \mathrm{E}-23$ & 0.31238983 & 0.35418686 & 0.3123898 & 0.3541869 \\
\hline
\end{tabular}


C/D Wood vs. Housing Permits: 28 Cities

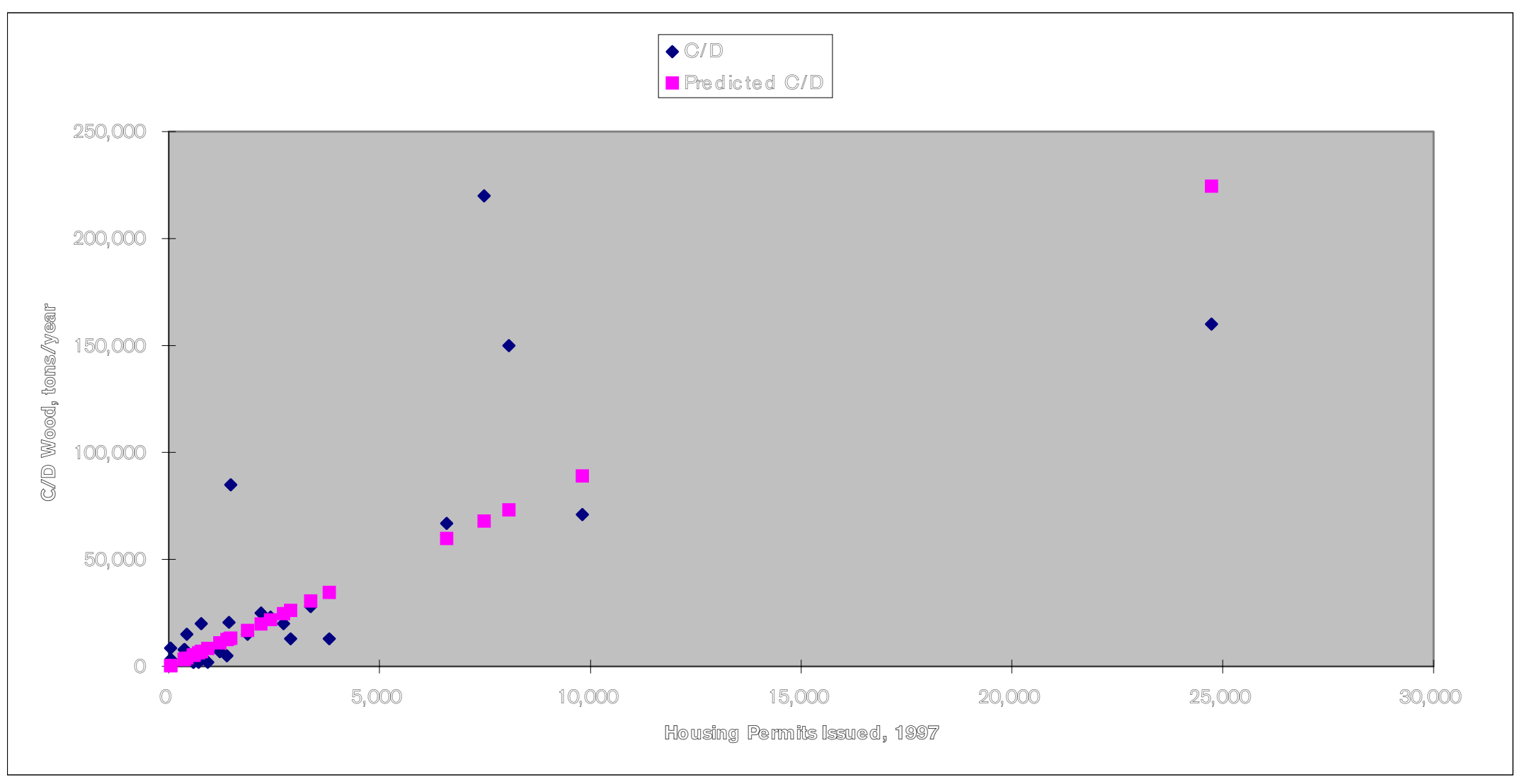

\begin{tabular}{lr}
\hline \multicolumn{2}{c}{ Regression Statistics } \\
\hline Multiple R & 0.7141477 \\
R Square & 0.510007 \\
Adjusted R Square & 0.4729699 \\
Standard Error & 38505.889 \\
Observations & 28 \\
\hline
\end{tabular}

ANOVA

\begin{tabular}{|c|c|c|c|c|c|}
\hline & $d f$ & $S S$ & $M S$ & $F$ & Significance $F$ \\
\hline Regression & 1 & $4.167 \mathrm{E}+10$ & $4.167 \mathrm{E}+10$ & 28.102824 & $1.52 \mathrm{E}-05$ \\
\hline Residual & 27 & $4.003 \mathrm{E}+10$ & $1.483 \mathrm{E}+09$ & & \\
\hline Total & 28 & $8.170 \mathrm{E}+10$ & & & \\
\hline
\end{tabular}

\begin{tabular}{lrccccccc}
\hline & Coefficients & Standard Error & t Stat & P-value & Lower 95\% & Upper 95\% & Lower 95.0\% & Upper 95.0\% \\
\hline Intercept & 0 & \#N/A & \#N/A & \#N/A & \#N/A & \#N/A & \#N/A & \#N/A \\
Permits & 9.0838878 & 1.2563681 & 7.230276 & $8.916 \mathrm{E}-08$ & 6.5060352 & 11.66174 & 6.5060352 & 11.66174 \\
\hline
\end{tabular}


Housing Permits vs. Population: 28 Cities

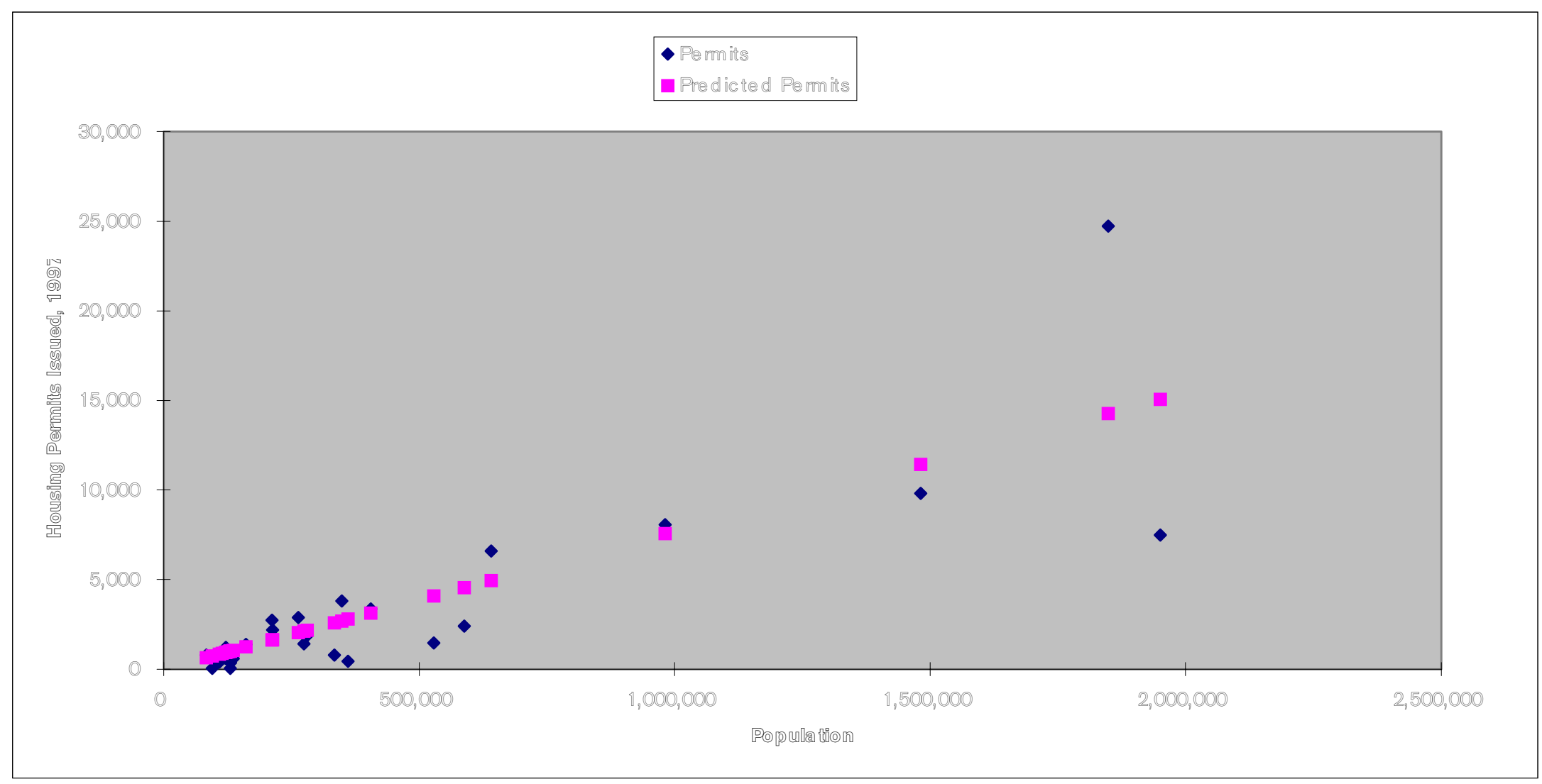

\begin{tabular}{lr}
\hline \multicolumn{2}{c}{ Regression Statistics } \\
\hline Multiple R & 0.8368179 \\
R Square & 0.7002643 \\
Adjusted R Square & 0.6632272 \\
Standard Error & 2717.2133 \\
Observations & 28 \\
\hline
\end{tabular}

ANOVA

\begin{tabular}{|c|c|c|c|c|c|}
\hline & $d f$ & $S S$ & $M S$ & $F$ & Significance $F$ \\
\hline Regression & 1 & 465730494 & 465730494 & 63.079352 & $2.026 \mathrm{E}-08$ \\
\hline Residual & 27 & 199347695 & 7383247.9 & & \\
\hline Total & 28 & 665078188 & & & \\
\hline
\end{tabular}

\begin{tabular}{lrccccccc}
\hline & Coefficients & Standard Error & t Stat & P-value & Lower 95\% & Upper 95\% & Lower 95.0\% & Upper 95.0\% \\
\hline Intercept & 0 & \#N/A & \#N/A & \#N/A & \#N/A & \#N/A & \#N/A & \#N/A \\
Population & 0.0077128 & 0.0007704 & 10.011253 & $1.386 \mathrm{E}-10$ & 0.006132 & 0.0092935 & 0.006132 & 0.0092935 \\
\hline \multicolumn{1}{c}{ C-13 }
\end{tabular}




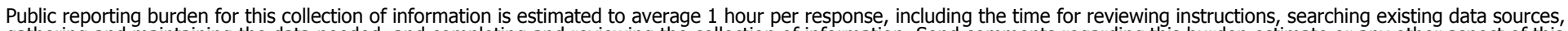

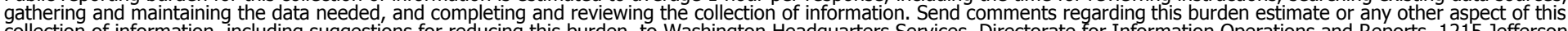

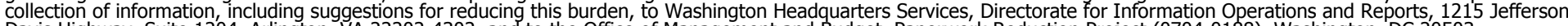

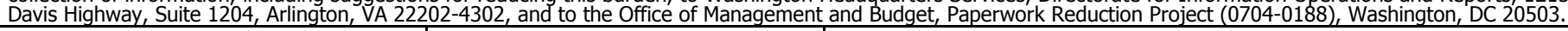

\begin{tabular}{|l|l|l|}
\hline 1. AGENCY USE ONLY (Leave blank) & $\begin{array}{r}\text { 2. REPORT DATE } \\
\text { November } 1998\end{array}$ & $\begin{array}{r}\text { 3. REPORT TYPE AND DATES COVERED } \\
\text { NREL Subcontract Report }\end{array}$ \\
\hline
\end{tabular}

4. TITLE AND SUBTITLE

Urban Wood Waste Resource Assessment

6. AUTHOR(S)

G. Wiltsee

7. PERFORMING ORGANIZATION NAME(S) AND ADDRESS(ES)

Appel consultants, Inc.

23905 Plaza Gavilan

Valencia, CA

9. SPONSORING/MONITORING AGENCY NAME(S) AND ADDRESS(ES)

National Renewable Energy Laboratory

1617 Cole Blvd.

Golden, CO 80401-3393
5. FUNDING NUMBERS

Task \#: BP911010

8. PERFORMING ORGANIZATION REPORT NUMBER

10. SPONSORING/MONITORING AGENCY REPORT NUMBER

NREL/SR-570-25918

\section{SUPPLEMENTARY NOTES}

NREL Technical Monitor:

12a. DISTRIBUTION/AVAILABILITY STATEMENT

National Technical Information Service

U.S. Department of Commerce

5285 Port Royal Road

Springfield, VA 22161 12b. DISTRIBUTION CODE

UC-600

13. ABSTRACT (Maximum 200 words) This study collected and analyzed data on urban wood waste resources in 30 randomly selected metropolitan areas in the United States. Three major categories (wood wastes disposed with, or recovered from, the municipal solid waste stream; industrial wood wastes such as wood scraps and sawdust from pallet recycling, woodworking shops, and lumberyards; and wood in construction/demolition and land clearing debris.

14. SUBJECT TERMS

municipal solid waste, industrial wood wastes, wood scraps, sawdust, waste diversion, waste recycling

17. SECURITY CLASSIFICATION OF REPORT
18. SECURITY CLASSIFICATION OF THIS PAGE
19. SECURITY CLASSIFICATION OF ABSTRACT
15. NUMBER OF PAGES 224

16. PRICE CODE 